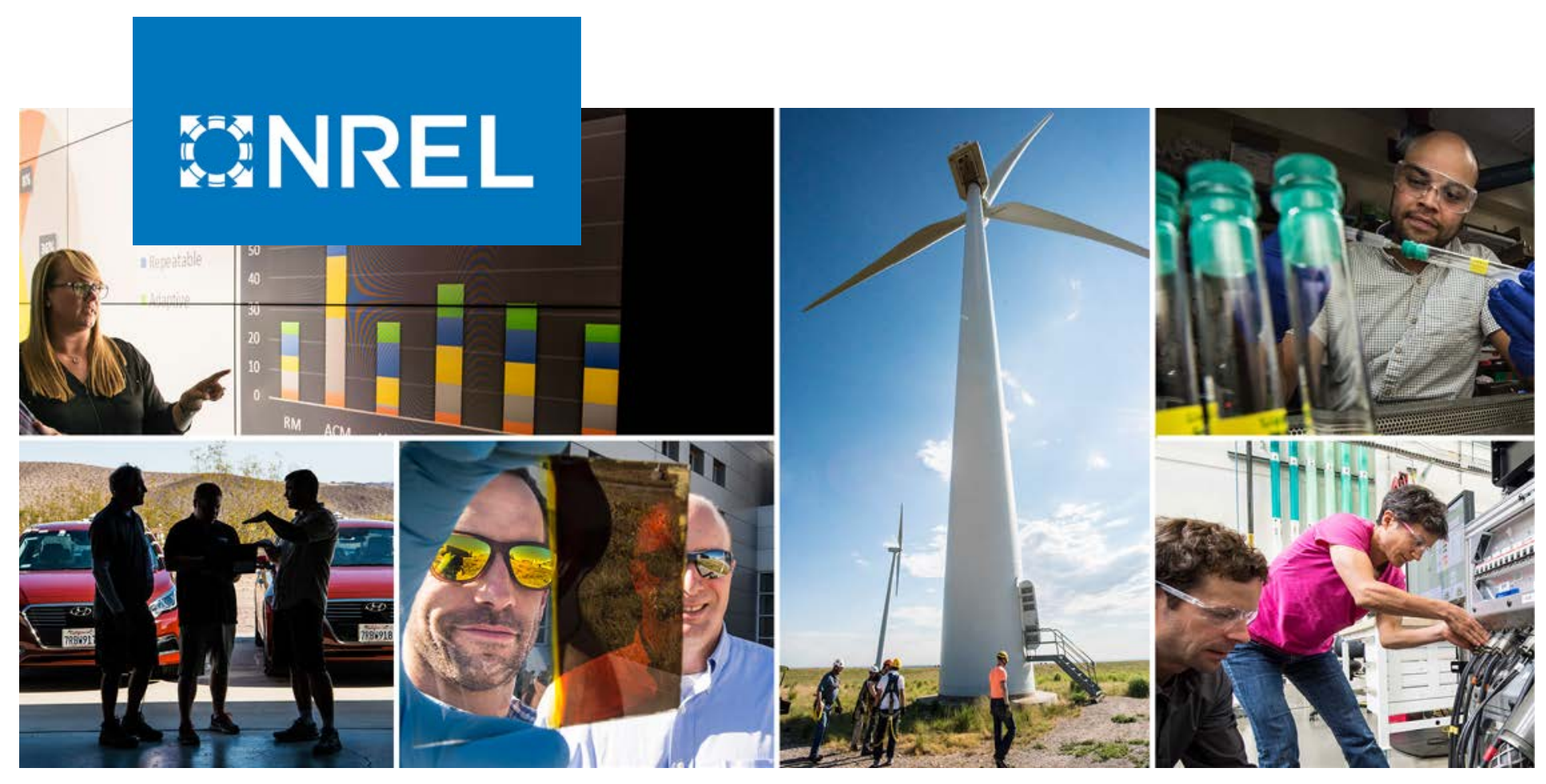

\title{
Techno-Economic Assessment for the Production of Hydrocarbon Fuels via Catalytic Upgrading of Furans
}

Bruno Klein, Ian McNamara, Ryan Davis, Ashutosh Mittal, and David Johnson

National Renewable Energy Laboratory

NREL is a national laboratory of the U.S. Department of Energy Office of Energy Efficiency \& Renewable Energy

Operated by the Alliance for Sustainable Energy, LLC

This report is available at no cost from the National Renewable Energy Laboratory (NREL) at www.nrel.gov/publications.
Technical Report

NREL/TP-5100-80652

September 2021 


\section{BNREL}

\section{Techno-Economic Assessment for the Production of Hydrocarbon Fuels via Catalytic Upgrading of Furans}

Bruno Klein, Ian McNamara, Ryan Davis, Ashutosh Mittal, and David Johnson

National Renewable Energy Laboratory

\section{Suggested Citation}

Klein, Bruno, Ian McNamara, Ryan Davis, Ashutosh Mittal, and David Johnson. 2021. Techno-Economic Assessment for the Production of Hydrocarbon Fuels via Catalytic Upgrading of Furans. Golden, CO: National Renewable Energy Laboratory. NREL/TP5100-80652. https://www.nrel.gov/docs/fy21osti/80652.pdf.

NREL is a national laboratory of the U.S. Department of Energy Office of Energy Efficiency \& Renewable Energy Operated by the Alliance for Sustainable Energy, LLC

This report is available at no cost from the National Renewable Energy Laboratory (NREL) at www.nrel.gov/publications.

Contract No. DE-AC36-08GO28308
Technical Report NREL/TP-5100-80652

September 2021

National Renewable Energy Laboratory 15013 Denver West Parkway Golden, CO 80401 303-275-3000 • www.nrel.gov 


\section{NOTICE}

This work was authored by the National Renewable Energy Laboratory, operated by Alliance for Sustainable Energy, LLC, for the U.S. Department of Energy (DOE) under Contract No. DE-AC36-08GO28308. Funding provided by the U.S. Department of Energy Office of Energy Efficiency and Renewable Energy Bioenergy Technologies Office. The views expressed herein do not necessarily represent the views of the DOE or the U.S. Government.

This report is available at no cost from the National Renewable Energy Laboratory (NREL) at www.nrel.gov/publications.

U.S. Department of Energy (DOE) reports produced after 1991 and a growing number of pre-1991 documents are available free via www.OSTI.gov.

Cover Photos by Dennis Schroeder: (clockwise, left to right) NREL 51934, NREL 45897, NREL 42160, NREL 45891, NREL 48097, NREL 46526.

NREL prints on paper that contains recycled content. 


\section{Nomenclature}

ACCE

BCD

BDO

BTU

CAPEX

$\mathrm{CO}_{2}$

CSL

CUBI

DMR

FCI

gal

GGE

HDO

HMF

IS

ISBL

$\mathrm{lb}$

LHV

MEK

MFSP

MM

MVR

NREL

NRTL

OPEX

PNNL

PSA

SS

TCI

TDC

TEA

VFP

WHSV

WWT
Aspen Capital Cost Estimator

base-catalyzed deconstruction

2,3-butanediol

British thermal unit

capital expenditures

carbon dioxide

corn steep liquor

Catalytic Upgrading of Biochemical Intermediates

deacetylation and mechanical refining

fixed capital investment

gallon

gallon gasoline equivalent

hydrodeoxygenation

hydroxymethylfurfural

insoluble solids

inside battery limits

pound

lower heating value

methyl ethyl ketone (2-butanone)

minimum fuel selling price

million

mechanical vapor recompression

National Renewable Energy Laboratory

nonrandom two-liquid

operational expenses

Pacific Northwest National Laboratory

pressure swing adsorption

soluble solids

total capital investment

total direct cost

techno-economic analysis

vacuum filter press

weight hourly space velocity

wastewater treatment 


\section{Executive Summary}

The U.S. Department of Energy Bioenergy Technologies Office promotes the production of liquid fuels from lignocellulosic feedstocks by sponsoring programs in fundamental and applied research that aim to advance the state of biomass conversion technologies. Biomass that has been deconstructed into sugars and sugar-derived intermediates via hydrolysis and fermentation can be converted into transportation fuels and bioproduct chemical streams via a multitude of routes, including chemical catalysis. The multi-lab Catalytic Upgrading of Biochemical Intermediates (CUBI) project within the Chemical Catalysis for Bioenergy Consortium (ChemCatBio) addresses critical barriers linked to the catalytic conversion of sugars and their intermediates into hydrocarbon fuels and coproducts. When incorporated within the broader biochemical conversion deconstruction process in a biorefinery context, developments under CUBI show that the key catalytic upgrading strategies under investigation exhibit potential to achieve a targeted minimum fuel selling price (MFSP) under $\$ 2.50$ per gallon gasoline equivalent (GGE) if value is added to lignin in the form of coproducts.

To support such efforts, the National Renewable Energy Laboratory (NREL) investigates the process design and economics of modeled cellulosic biorefineries in order to develop a plant gate price for fuels and bio-derived products. This report documents the techno-economic analysis (TEA) implications of a biochemical/catalytic pathway for the production of long-chain hydrocarbon fuels and proposes two distinct conceptual biorefineries centered around the process encompassing sugar dehydration to furans, aldol condensation between furans and a ketone (methyl ethyl ketone [MEK]), and a final step of hydrotreating to obtain hydrocarbons in the $\mathrm{C}_{14}-\mathrm{C}_{16}$ range. The integrated plant simultaneously produces both furans (furfural and hydroxymethylfurfural [HMF]) and ketone (MEK via 2,3-butanediol [BDO]) from sugars; on the other hand, a dedicated biorefinery focuses on exclusively producing furans from corn stover hydrolysate and procuring the ketone externally. In either plant, the main coproducts are adipic acid (derived from lignin) and sodium sulfate. This study is based on detailed process simulations and TEA to determine MFSP for the main hydrocarbon fuel product. Because this report considers long-term performance targets for the full pathway dedicated to sugar upgrading to fuels, the critical remaining research points needed to achieve future cost goals are also discussed.

TEA results estimate the MFSP of the dedicated and integrated biorefineries at \$2.54/GGE and \$2.72/GGE (2016-dollars), respectively, with corresponding fuel yields of 108.4 and 61.2 GGE/dry ton of biomass. The assessment also clearly reiterates the need for valorizing the lignin fraction to a high-value coproduct in order to achieve such MFSP levels: At a yield of 284 and $276 \mathrm{lb} /$ dry ton of biomass, respectively, the coproduction of adipic acid contributes to overall MFSPs at credits corresponding to negative $\$ 1.23 / \mathrm{GGE}$ and $\$ 2.16 / \mathrm{GGE}$ for the respective cases. Although adipic acid has been chosen as the bio-derived lignin coproduct in this work in keeping with prior NREL TEA design case studies, a number of other molecules with industrial application could have the same positive effect on overall biorefinery economics. Notably, the MFSP results highlighted here are quite comparable to those reported in NREL's aforementioned design case focused on biological conversion of sugars to fermentation intermediates with subsequent catalytic upgrading of those intermediates to hydrocarbon fuels, at \$2.47$\$ 2.49 / \mathrm{GGE}$, thus presenting another viable alternative pathway to achieve similar fuel cost targets through purely catalytic upgrading of sugars in this case. 
A single-point sensitivity analysis around selected parameters was also conducted to identify the major cost drivers of the biorefineries. The main factor for both biorefining setups is adipic acid coproduct price, which could lead to large swings in MFSP depending on its market value. For sugar-to-fuel catalysis details in the context of the primary focus of this report, in the case of the dedicated plant, the price at which MEK is purchased could also lead to significantly different MFSP results. Whether produced internally via the integrated plant or procured externally for the dedicated plant, it will be crucial for both economic and life cycle considerations to ultimately source the ketone co-reactant through a renewable or otherwise low-carbon-intensity process. The furans pathway influences the economic performance of the biorefinery, especially through the yield achievable in sugar dehydration: A high yield is desirable to keep processing costs low on a per-GGE basis because a reduction in this parameter directly decreases the overall fuel yield of the plant.

Finally, the report provides a qualitative discussion on additional opportunities for cost reduction within the proposed biorefineries, namely through adding value to furans, to coproducts that may be obtained following BDO dehydration, and to lignin through alternative pathways. 


\section{Dedicated Biorefinery for Hydocarbon Fuel Production: Process Engineering Analysis}

DMR Pretreatment, Enzymatic Hydrolysis \& Catalytic Upgrading of Sugars, Lignin Conversion to Coproducts

All Values in 2016\$

Minimum Fuel Selling Price

(MFSP, Gasoline-Equivalent Basis):

$$
\begin{array}{r}
\text { Contributions: } \begin{array}{r}
\text { Feedstock } \\
\text { Fuel Conversion } \\
\text { Coproduct Conversion }
\end{array} \\
\text { Fuel Production } \\
\text { Fuel Yield } \\
\text { Adipic Acid Coproduct Yield } \\
\text { Feedstock + Handling Cost } \\
\text { Internal Rate of Return (After-Tax) } \\
\text { Equity Percent of Total Investment }
\end{array}
$$

\section{$\$ 2.54$ /GGE}

\$0.66/GGE

\begin{tabular}{|c|c|}
\hline \multicolumn{2}{|l|}{ Capital Costs } \\
\hline Area 200: Pretreatment & $\$ 48,700,000$ \\
\hline Area 300: Sugar Hydrolysis and Conditioning & $\$ 59,800,000$ \\
\hline Area 400: Enzyme Production & $\$ 11,500,000$ \\
\hline Area 500: Furans Production and Upgrading & $\$ 43,000,000$ \\
\hline Area 600: Wastewater & $\$ 31,300,000$ \\
\hline Area 700: Lignin & $\$ 140,000,000$ \\
\hline Area 800: Boiler & $\$ 60,100,000$ \\
\hline Area 900: Utilities \& Storage & $\$ 20,000,000$ \\
\hline Total Installed Equipment Cost & $\$ 414,400,000$ \\
\hline Added Direct + Indirect Costs & $\$ 372,500,000$ \\
\hline$(\%$ of $\mathrm{TCl})$ & $47 \%$ \\
\hline Total Capital Investment (TCl) & $\$ 786,900,000$ \\
\hline Installed Equipment Cost/Annual GGE & $\$ 5.28$ \\
\hline Total Capital Investment/Annual GGE & $\$ 10.02$ \\
\hline Operating Hours Per Year (On-Stream Factor) & $7884(90 \%)$ \\
\hline Loan Rate & $8.0 \%$ \\
\hline Term (years) & 10 \\
\hline Capital Charge Factor (Computed) & 0.131 \\
\hline \multicolumn{2}{|l|}{ Specific Operating Conditions } \\
\hline Enzyme Loading (mg/g cellulose) & 10.0 \\
\hline Net Electricity Import (kWh/GGE) & 5.2 \\
\hline Plant Electricity Use (kWh/GGE) & 6.9 \\
\hline
\end{tabular}

$\$ 3.11 / G G E$

$-\$ 1.23 / G G E$

78.5 MMGGE per year

108.4 GGE / dry U.S. ton feedstock

$284 \mathrm{lb} /$ dry U.S. ton feedstock

$\$ 71.26 /$ dry U.S. ton feedstock

$10 \%$

$40 \%$

Manufacturing Costs (cents/GGE fuel product)

\begin{tabular}{ll}
\hline Feedstock + Handling & 65.7
\end{tabular}

Sulfuric Acid 11.0

Caustic $\quad 54.2$

Glucose (enzyme production) 10.8

Hydrogen 63.8

Electricity (import) $\quad 35.1$

Natural Gas

Methyl Ethyl Ketone $\quad 61.8$

Other Raw Materials $\quad 24.2$

1.8

Waste Disposal 1.8

$\mathrm{Na}_{2} \mathrm{SO}_{4}$ Coproduct $\quad-21.5$

Adipic Acid coproduct $(\$ 0.86 / \mathrm{lb}) \quad-223.6$

Fixed Costs $\quad 26.0$

Capital Depreciation 31.7

$\begin{array}{lr}\text { Average Income Tax } & 9.9\end{array}$

\begin{tabular}{lr} 
Average Return on Investment & 89.4 \\
\hline
\end{tabular}

\begin{tabular}{lr}
\hline Total & 853.9 \\
\hline
\end{tabular}

Manufacturing Costs $(\$ / y r)$

Feedstock + Handling $\$ 51,600,000$

$\begin{array}{lr}\text { Sulfuric Acid } & \$ 8,600,000\end{array}$

$\$ 42,600,000$

Glucose (enzyme production) \$8,400,000

Hydrogen $\$ 50,100,000$

Electricity (import) \$27,600,000

Natural Gas $\$ \$ 9,400,000$

Methyl Ethyl Ketone $\$ \$ 4,500,000$

Other Raw Materials $\$ \$ 19,000,000$

Catalysts $\$ \$ 1,400,000$

Waste Disposal $\$ \$ 1,400,000$

$\mathrm{Na}_{2} \mathrm{SO}_{4}$ Coproduct $\quad-\$ 16,900,000$

Adipic Acid coproduct $(\$ 0.86 / \mathrm{lb}) \quad-\$ 175,700,000$

Fixed Costs $\$ 20,400,000$

Capital Depreciation $\$ 24,900,000$

Average Income Tax $\$ \$ 7,800,000$

Average Return on Investment $\$ \$ 70,200,000$

\begin{tabular}{lr}
\hline Total & $\$ 199,300,000$
\end{tabular}

Figure ES-1. Economic summary for catalytic upgrading of sugars in a dedicated biorefinery 


\section{Integrated Biorefinery for Hydocarbon Fuel Production: Process Engineering Analysis}

DMR Pretreatment, Enzymatic Hydrolysis \& Fermentation / Catalytic Upgrading of Sugars, Lignin Conversion to Coproducts

All Values in $2016 \$$

Minimum Fuel Selling Price

(MFSP, Gasoline-Equivalent Basis):

Contributions: Feedstock
Fuel Conversion

Coproduct Conversion

Fuel Production

Fuel Yield

Adipic Acid Coproduct Yield

Feedstock + Handling Cost

Internal Rate of Return (After-Tax)

Equity Percent of Total Investment

\section{\$2.72 /GGE}

$\$ 1.17$ /GGE

$\$ 3.71 / G G E$

$-\$ 2.16 / G G E$

44.3 MMGGE per year

61.2 GGE / dry U.S. ton feedstock

$276 \mathrm{lb} /$ dry U.S. ton feedstock

$\$ 71.26 /$ dry U.S. ton feedstock

$10 \%$

$40 \%$

Manufacturing Costs (cents/GGE fuel product)

\begin{tabular}{|c|c|}
\hline Area 200: Pretreatment & $\$ 48,700,000$ \\
\hline Area 300: Sugar Hydrolysis and Conditioning & $\$ 42,100,000$ \\
\hline Area 400: Enzyme Production & $\$ 11,500,000$ \\
\hline Area 500: Furans Production and Upgrading & $\$ 29,600,000$ \\
\hline Area 550: MEK Production & $\$ 25,100,000$ \\
\hline Area 600: Wastewater & $\$ 35,700,000$ \\
\hline Area 700: Lignin & $\$ 134,700,000$ \\
\hline Area 800: Boiler & $\$ 70,400,000$ \\
\hline Area 900: Utilities \& Storage & $\$ 18,000,000$ \\
\hline Total Installed Equipment Cost & $\$ 415,800,000$ \\
\hline Added Direct + Indirect Costs & $\$ 370,400,000$ \\
\hline$(\%$ of $\mathrm{TCl})$ & $47 \%$ \\
\hline Total Capital Investment (TCl) & $\$ 786,200,000$ \\
\hline Installed Equipment Cost/Annual GGE & $\$ 9.39$ \\
\hline Total Capital Investment/Annual GGE & $\$ 17.75$ \\
\hline Operating Hours Per Year (On-Stream Factor) & $7884(90 \%)$ \\
\hline Loan Rate & $8.0 \%$ \\
\hline Term (years) & 10 \\
\hline Capital Charge Factor (Computed) & 0.129 \\
\hline \multicolumn{2}{|l|}{ Specific Operating Conditions } \\
\hline Enzyme Loading (mg/g cellulose) & 10.0 \\
\hline Net Electricity Import (kWh/GGE) & 6.4 \\
\hline Plant Electricity Use (kWh/GGE) & 10.9 \\
\hline
\end{tabular}

\begin{tabular}{|c|c|}
\hline Feedstock + Handling & 116.5 \\
\hline Sulfuric Acid & 19.0 \\
\hline Caustic & 88.8 \\
\hline Glucose (enzyme production) & 19.1 \\
\hline Hydrogen & 63.5 \\
\hline Electricity (import) & 42.3 \\
\hline Natural Gas & 31.8 \\
\hline Other Raw Materials & 32.9 \\
\hline Catalysts & 4.3 \\
\hline Waste Disposal & 3.2 \\
\hline $\mathrm{Na}_{2} \mathrm{SO}_{4}$ Coproduct & -38.7 \\
\hline Adipic Acid coproduct (\$0.86/lb) & -385.8 \\
\hline Fixed Costs & 45.3 \\
\hline Capital Depreciation & 56.2 \\
\hline Average Income Tax & 17.4 \\
\hline Average Return on Investment & 155.8 \\
\hline Total & 271.6 \\
\hline \multicolumn{2}{|l|}{ Manufacturing Costs $(\$ / y r)$} \\
\hline Feedstock + Handling & $\$ 51,600,000$ \\
\hline Sulfuric Acid & $\$ 8,400,000$ \\
\hline Caustic & $\$ 39,300,000$ \\
\hline Glucose (enzyme production) & $\$ 8,400,000$ \\
\hline Hydrogen & $\$ 28,100,000$ \\
\hline Electricity (import) & $\$ 18,700,000$ \\
\hline Natural Gas & $\$ 14,100,000$ \\
\hline Other Raw Materials & $\$ 14,600,000$ \\
\hline Catalysts & $\$ 1,900,000$ \\
\hline Waste Disposal & $\$ 1,400,000$ \\
\hline $\mathrm{Na}_{2} \mathrm{SO}_{4}$ Coproduct & $-\$ 17,100,000$ \\
\hline Adipic Acid coproduct (\$0.86/lb) & $-\$ 170,900,000$ \\
\hline Fixed Costs & $\$ 20,100,000$ \\
\hline Capital Depreciation & $\$ 24,900,000$ \\
\hline Average Income Tax & $\$ 7,700,000$ \\
\hline Average Return on Investment & $\$ 69,000,000$ \\
\hline
\end{tabular}

Figure ES-2. Economic summary for catalytic upgrading of sugars in an integrated biorefinery 


\section{Table of Contents}

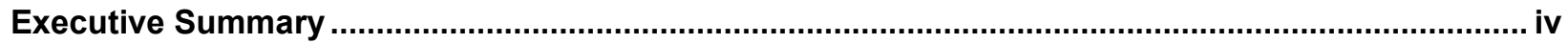

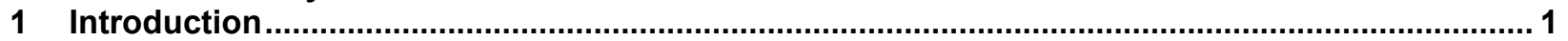

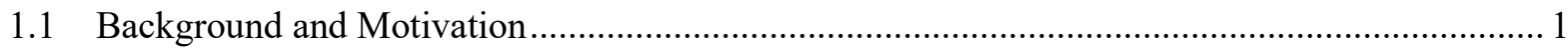

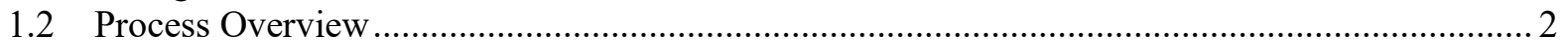

1.3 Techno-Economic Analysis Approach and Assumptions ................................................... 6

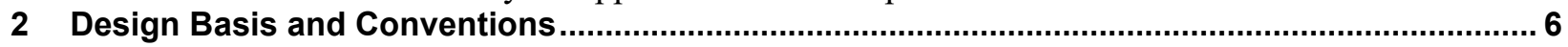

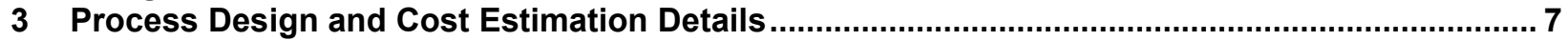

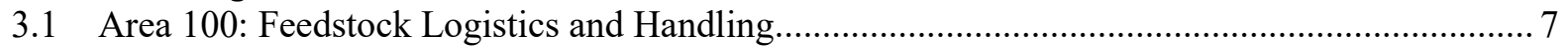

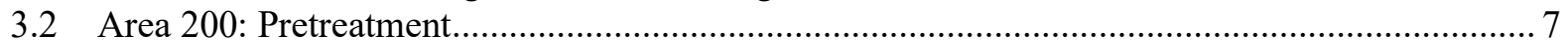

3.3 Area 300: Enzymatic Hydrolysis and Hydrolysate Conditioning .............................................. 8

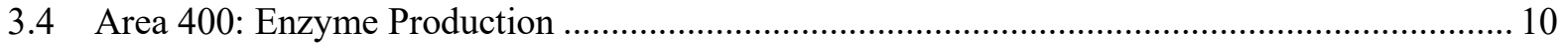

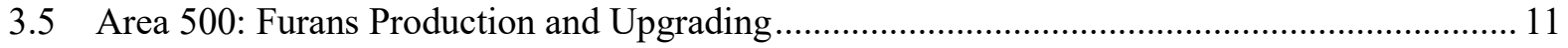

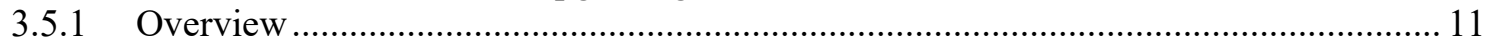

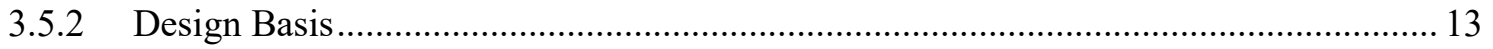

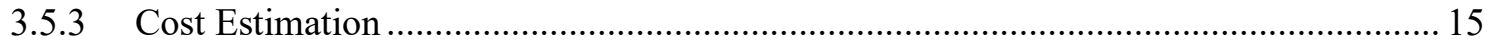

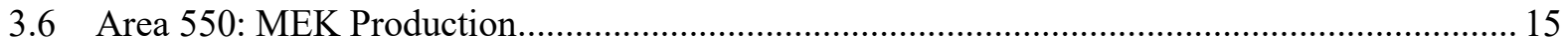

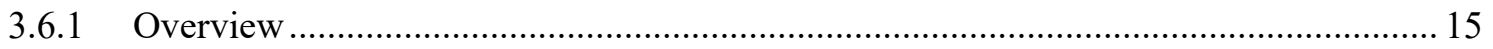

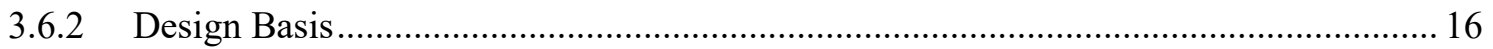

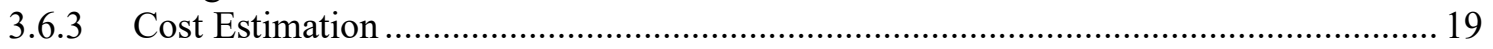

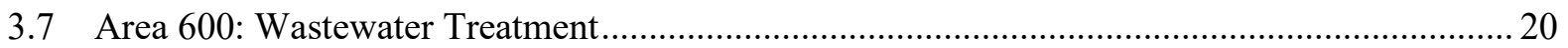

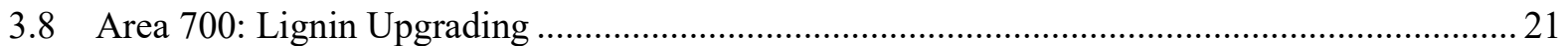

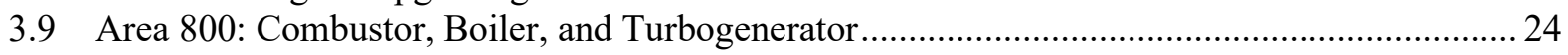

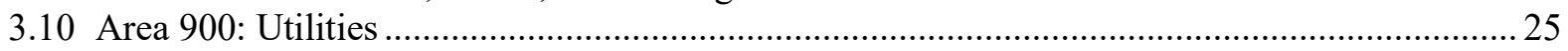

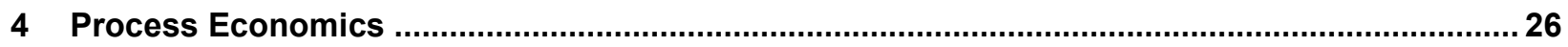

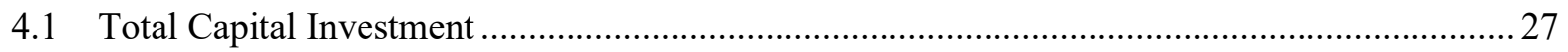

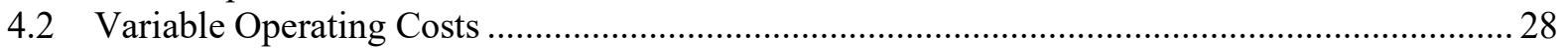

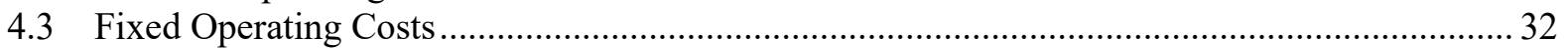

4.4 Discounted Cash Flow Analysis and the Minimum Fuel Selling Price .................................... 33

4.4.1 Discount Rate, Equity Financing, and Other Financial Metrics................................... 33

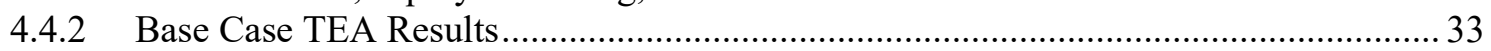

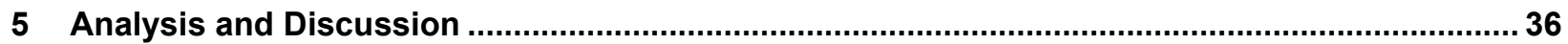

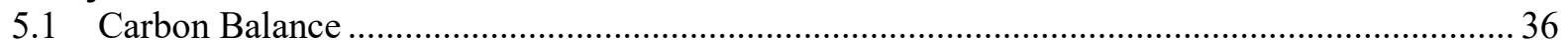

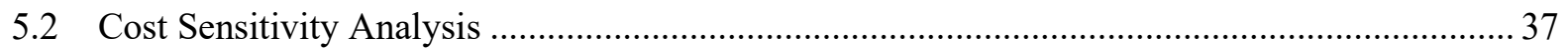

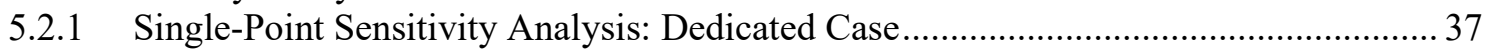

5.2.2 Single-Point Sensitivity Analysis: Integrated Case .................................................... 39

5.2.3 Case Study: Experimental Baseline ....................................................................... 41

5.2.4 Case Study: BDO Fermentation with Clarified Hydrolysate ................................... 42

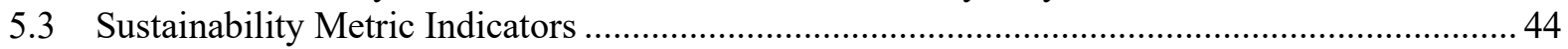

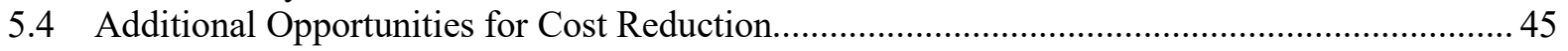

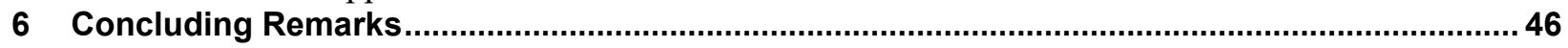

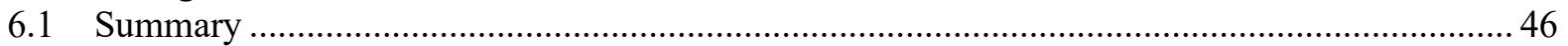

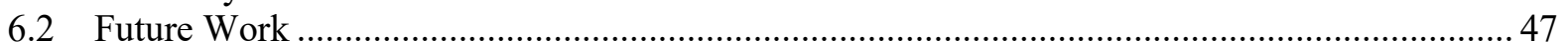

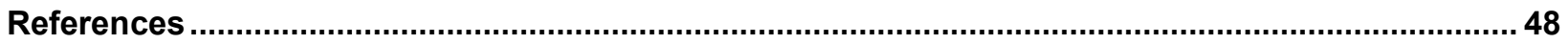

Appendix A. Individual Equipment Costs Summary ...............................................................5

Appendix B. Discounted Cash Flow Rate of Return Worksheet ......................................................6 60

Appendix C. Key Aspen Stream Data Tables ...................................................................................64 


\section{Introduction}

\subsection{Background and Motivation}

The U.S. Department of Energy Bioenergy Technologies Office promotes the production of liquid fuels from lignocellulosic feedstocks by sponsoring programs in fundamental and applied research that aim to advance the state of biomass conversion technology. These programs include research to develop improved bioconversion organisms, chemical catalysts, hydrolysis enzymes, and integrated unit operations through synthetic biology, catalyst development and testing, chemical and mechanical pretreatment work, detailed engineering studies of potential processes, and construction of pilot-scale demonstration and production facilities. To support this work, the National Renewable Energy Laboratory (NREL) investigates the process design and economics of modeled cellulosic biorefineries in order to develop a plant gate price for fuels and bioderived products. Through process modeling and techno-economic analysis (TEA), a modeled biorefinery's minimum fuel selling price (MFSP) may be quantified to reflect the economic viability for a given conversion technology pathway attributed to a set of technical parameters for the process.

Generally speaking, biochemical conversion technology approaches that operate based on the conversion of targeted biomass constituents to targeted product molecules may be divided into biomass deconstruction operations (i.e., pretreatment/fractionation of biomass into convertible components) and intermediate upgrading operations (i.e., biological or catalytic upgrading of those convertible components into fuels or products). NREL maintains extensive focus on both deconstruction and conversion processes, with numerous TEA reports released over recent years reflecting various strategies for the biochemical deconstruction and conversion technology pathways that may be taken in an integrated biorefinery [1-4].

Biomass that has been deconstructed into sugars and sugar-derived intermediates via hydrolysis and fermentation can be converted into transportation fuels and bioproduct chemical streams via a multitude of routes, including chemical catalysis. The multi-lab Catalytic Upgrading of Biochemical Intermediates (CUBI) project within the Chemical Catalysis for Bioenergy Consortium (ChemCatBio) is dedicated to addressing critical barriers linked to the catalytic conversion of such biomass-derived sugars and their intermediates into hydrocarbon fuels and coproducts. Most biochemical conversion pathways involving fermentation of lignocellulosic sugars are challenged by (1) requiring complete hydrolysis of carbohydrates into monomeric sugars, and (2) carbon efficiency penalties incurred by evolution of carbon dioxide $\left(\mathrm{CO}_{2}\right)$ during the fermentation process. Chemical catalysis may offer the potential to alleviate some of these challenges, given appropriate insertion points to be integrated into biochemical conversion processes. When incorporated within the broader biochemical conversion deconstruction process and when coupled with opportunities for lignin coproduct valorization, developments under CUBI show that the key catalytic upgrading strategies under investigation exhibit potential to achieve a targeted MFSP under $\$ 2.50$ per gallon gasoline equivalent (GGE).

Among the multiple catalytic upgrading strategies developed under CUBI, including the conversion of intermediates such as carboxylic acids, 2,3-butanediol (BDO) via butenes or methyl ethyl ketone (MEK), and furans, this report focuses on establishing TEA models for the latter approach via direct catalysis of sugars, with or without a parallel fermentation step (optionally included as a means of providing a ketone co-reactant for catalytic upgrading). Two 
main biorefinery options were designed to deconstruct and hydrolyze biomass to sugars and convert them into chemicals required for the synthesis of hydrocarbon fuels. The integrated plant produces both furans (furfural and hydroxymethylfurfural [HMF]) and a ketone (MEK) from sugars, whereas the dedicated biorefinery focuses on exclusively producing furans from corn stover hydrolysate and procuring the ketone externally. Either approach is an alternative route to synthesize hydrocarbon fuels, relative to pathways presented in a recent biochemical design report [1]. Figure 1 presents a simplified process flow diagram of the strategies assessed in this work.

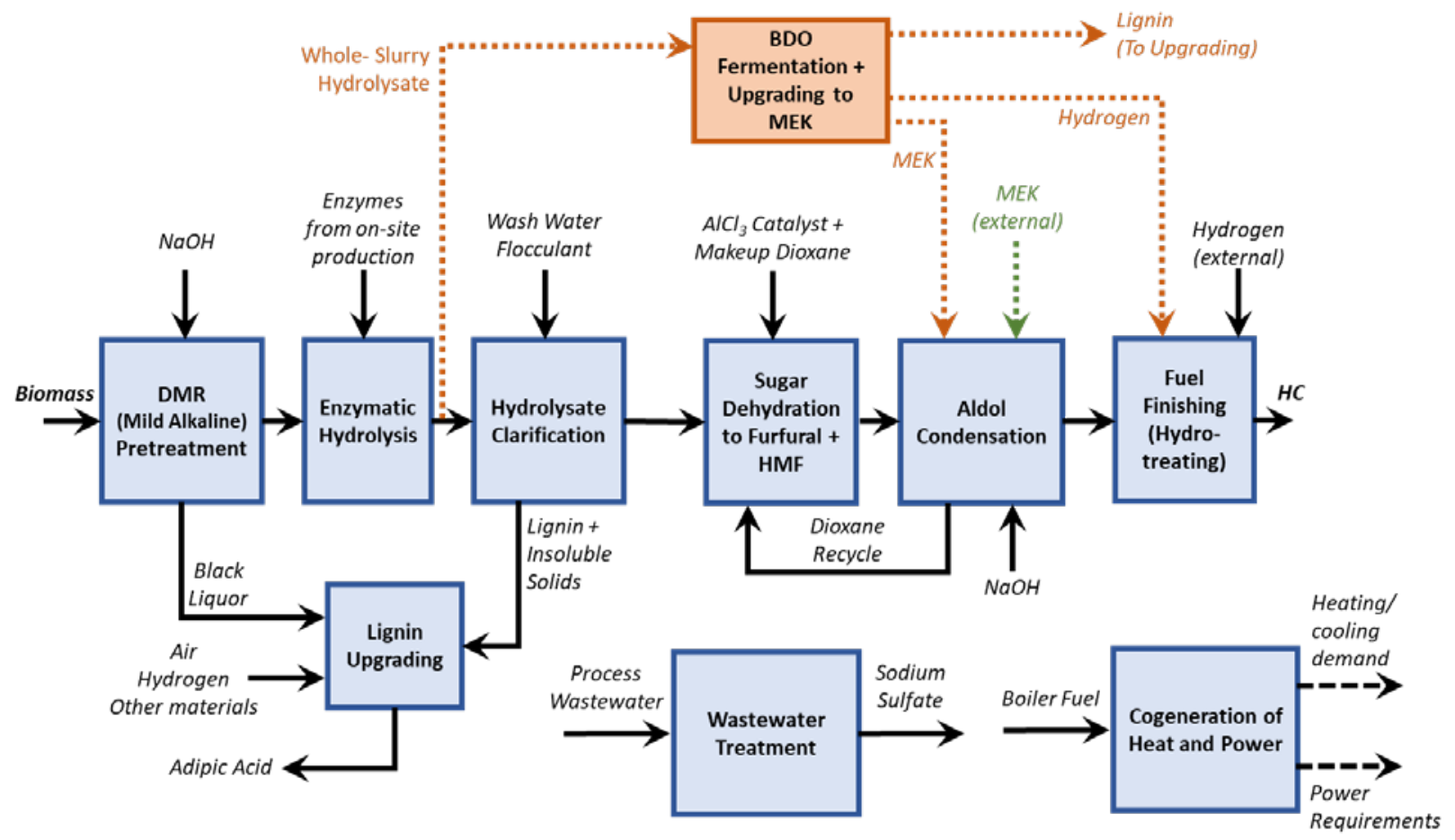

Figure 1. Simplified representation of the biorefining configurations assessed in this report. Blue boxes represent sections included in both biorefining configurations, whereas the green arrow is specific to the dedicated case and the orange objects are representative of the integrated plant.

As in previous efforts, the TEA models presented here solve for the MFSP of the hydrocarbon product as the main economic metric, after including coproduct revenues from the sale of adipic acid produced from lignin deconstruction and upgrading, set at a fixed market price. This is a useful metric to address the feasibility of each production route when compared to other technologies. Through process simulation and TEA, which is the basis for this assessment, it is possible to determine the critical remaining research needed to achieve future cost goals.

\subsection{Process Overview}

As previously indicated, this report addresses the production of a renewable hydrocarbon fuel blendstock through two biorefining configurations: a dedicated biorefinery, in which sugars are exclusively converted into furans and the MEK co-reactant is purchased externally, and an integrated biorefinery, which combines fermentative and catalytic pathways for conversion of sugars into fuel precursor intermediates (both furans and MEK at the necessary ratios). Either route draws much of the configuration from previous design reports, namely areas outside the 
conversion of sugars, and accordingly we defer to those prior reports for a detailed accounting of the associated process details and model inputs.

The process starts with a deacetylation/mild alkaline extraction and mechanical refining pretreatment of corn stover, followed by enzymatic hydrolysis (saccharification) of the cellulose and hemicellulose for solubilization of sugar.

In the integrated option, part of the hydrolysate is routed to BDO fermentation and further upgraded to MEK. The remainder of the slurry is filtered and concentrated, and the clarified hydrolysate is dehydrated to furfural and HMF. The resulting intermediates (furans and MEK) are then combined in an aldol condensation reaction to form higher-molecular-weight, oxygenated intermediates. The intermediates are subsequently catalytically upgraded to final hydrocarbon fuel products. In the dedicated biorefinery, in contrast, all of the enzymatic hydrolysis stream is sent to a vacuum filter press (VFP) and further concentrated prior to being routed to the production of furans; MEK is sourced externally for aldol condensation. Both biorefineries include lignin valorization in the setup. Lignin is initially deconstructed to soluble monomers and converted (along with other biomass residual components) to muconic acid, which is purified and further upgraded to adipic acid for sale as a coproduct. The facility also includes feedstock handling and storage, wastewater treatment (WWT), residual waste combustion, product storage, and utilities. The process is divided into 10 areas (Figure 2). Except for Area 500, which is the development focus of CUBI and the core section assessed in this report, and Area 550, which is also closely related to another pathway under investigation in CUBI, all other areas are only briefly summarized because they maintain the same details and modeling inputs as documented in the 2018 design report [1].

Area 100: Feedstock logistics and handling. The biorefinery is designed to process 2,000 dry metric tonnes of corn stover per day. All Area 100 processing aspects are outside the scope of this work and are combined into delivered feedstock costs at the pretreatment section (Area 200).

Area 200: Pretreatment. In this area, the biomass is processed with a deacetylation and mechanical refining (DMR) pretreatment approach, which comprises the preferential solubilization and removal of acetate and other biomass components with the use of an alkali extraction step, as well as sequential disc refining operations.

Area 300: Enzymatic hydrolysis and hydrolysate conditioning. Enzymatic hydrolysis is initiated in a high-solids continuous reactor using a cellulase enzyme produced on site and completed in parallel batch reactors. Part of these vessels are also employed for BDO fermentation (Area 550). In the dedicated plant, the hydrolysate is fully processed in a flocculant-assisted vacuum filter to remove solids (routed to the lignin train), and the clarified liquor is concentrated prior to use in Area 500. In the integrated biorefinery, part of the hydrolysate is diverted to Area 550 for whole-slurry BDO fermentation; the remainder of the hydrolysate is clarified and concentrated as previously indicated before being routed to Area 500 .

Area 400: Enzyme production. An on-site enzyme production section was maintained in this design, consistent with details provided in prior design reports. The whole broth from Area 400, containing the enzyme secreted by Trichoderma reesei, is fed to Area 300 to carry out enzymatic hydrolysis. 
Area 500: Furans production and upgrading. The integrated biorefinery reroutes around 55\% of the clarified, concentrated hydrolysate from Area 300 to the sugar dehydration reaction to form furans. Furfural and HMF present in the reactional mixture are then sent to an aldol condensation reactor, in which heavier oxygenated compounds (condensates) are synthesized with MEK as an additional reactant. MEK for this reaction is sourced from Area 550. The dedicated plant follows a similar path, only differing in that all sugars in the concentrated hydrolysate are sent to sugar dehydration and MEK is purchased to carry out the aldol condensation reaction. In both biorefineries, condensates ultimately undergo catalytic upgrading to hydrocarbon fuels through hydrotreating.

Area 550: MEK production. Whole slurry reserved from Area 300 (approximately $45 \%$ of total sugars) is sent to a batch anaerobic fermentation to BDO. The resulting BDO broth is clarified in a lignin filter press and then catalytically converted into MEK and other coproducts. MEK is recovered and routed to the aldol condensation reaction. Area 550 is exclusive to the integrated approach.

Area 600: Wastewater treatment. Wastewater streams from Areas 500 and 700 are treated by aerobic digestion and reverse osmosis to remove organics and salts, respectively. Sodium sulfate salt recovered from the brine is sold as a secondary coproduct to offset a portion of the caustic and acid demands/costs incurred throughout the integrated design.

Area 700: Lignin upgrading. This section focuses on upgrading lignin monomers and other residual (soluble) components to muconic acid via fermentation and further upgrading to adipic acid (finished coproduct, which is sold). Carbon sources for bioconversion are the black liquor from DMR pretreatment and the residual solids separated downstream after enzymatic hydrolysis and (in the integrated case) BDO fermentation.

Area 800: Combustor, boiler, and turbogenerator. The residual solids, wastewater sludge, and off-gas streams are combusted to generate high-pressure steam for heat and power.

Area 900: Utilities. This area includes a cooling water system, chilled-water system, process water manifold, and power systems. 


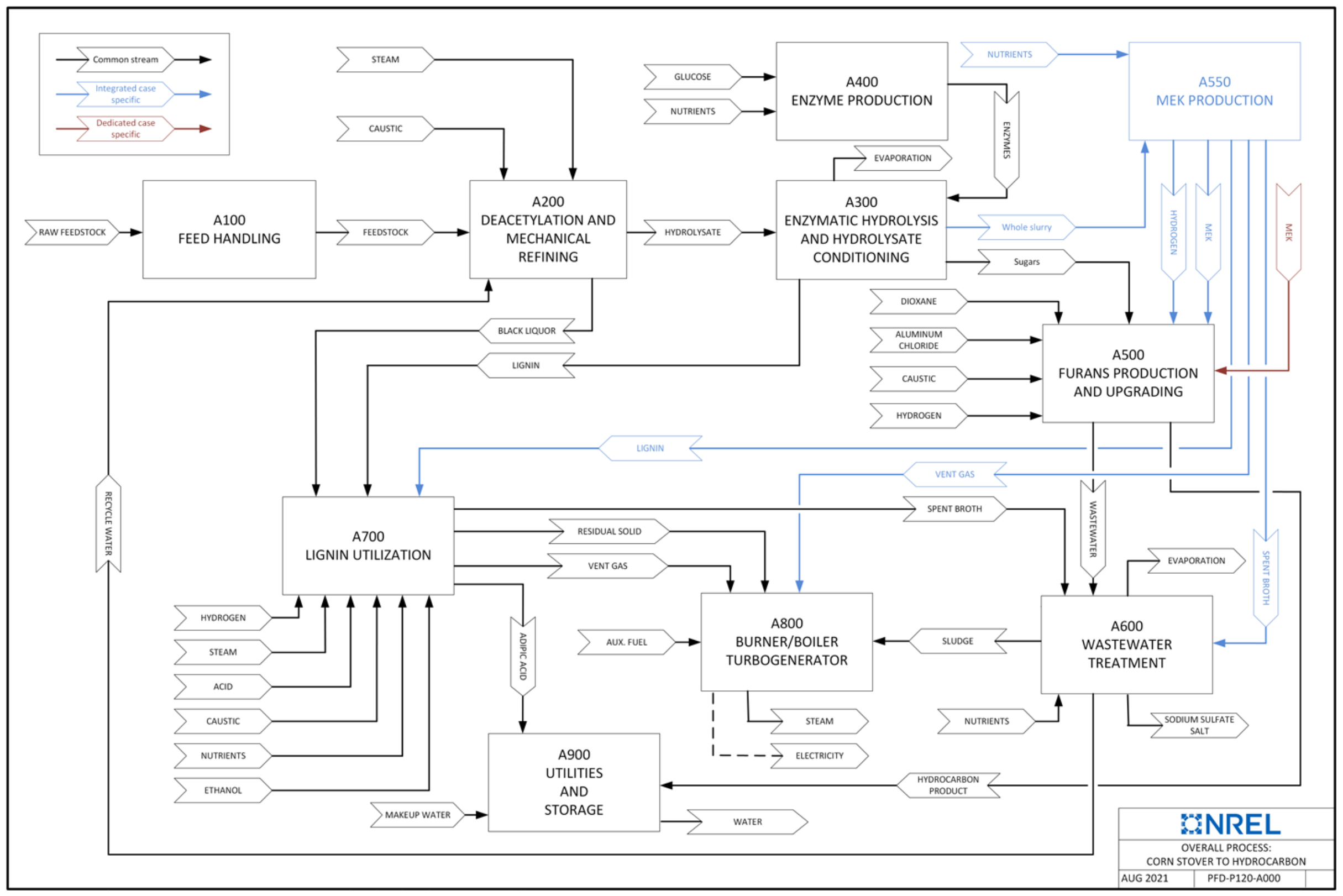

Figure 2. Simplified flow diagram of the overall processes 


\subsection{Techno-Economic Analysis Approach and Assumptions}

The main goal of this analysis is to establish a techno-economic model to estimate an MFSP linked to the production of hydrocarbon fuels in a biorefinery context. The approach followed in this work is similar to previous efforts $[3,4]$.

Initially, process flow diagrams are established with the aid of researchers to ensure the validity of the proposed biorefining approach. The block flow diagram in Figure 2 is a direct result from this step. Then, process simulations are built and run in Aspen Plus to generate mass and energy balances, which are further employed to determine fixed and variable operational expenses (OPEX), as well as capital expenditures (CAPEX) with equipment purchase. The nonrandom two-liquid (NRTL) model is used as the base thermodynamic model throughout the simulations (with notable exceptions such as the Peng-Robinson or Soave-Redlich-Kwong equations of state and NRTL variations for specific unit operations). Baseline equipment costs may come from a multitude of sources, including vendor quotations, scientific literature, NREL and subcontractor historical cost data, or estimated with the built-in Aspen Capital Cost Estimator (ACCE) in Aspen Plus. Once equipment costs are determined, direct and indirect overhead cost factors (e.g., installation costs and project contingency) are applied to determine the total capital investment (TCI) in 2016\$. The TCI and the plant OPEX are then used to establish a discounted cash flow rate of return (DCFROR) and to calculate the MFSP (in \$/GGE) at a $10 \%$ internal rate of return over a 30-year plant lifetime. The underlying cost estimates and TEA modeling approach are compatible with an AACE Class 4 level of analysis [5], with an estimated uncertainty of approximately $\pm 25 \%$ in the determined TCI [6].

\section{Design Basis and Conventions}

This section briefly presents considerations on biorefinery size, feedstock specifications, and modeling basis. Table 1 summarizes the main parameters linked to the commercial biorefinery modeled in this report. It is important to point out that such parameters are reflective of $n^{\text {th }}$-plant commercial-scale designs, which implies that several facilities of the same type have already been built and that the technology in question is mature, in agreement with what has been described in the 2018 design report. It should be clear that pioneer plants (first-of-a-kind) would present a different set of specifications that would influence its economic assessment.

Table 1. Design Basis for the Modeled Biorefineries

\begin{tabular}{lc}
\hline Parameter & Value \\
\hline Plant nameplate capacity & 2,205 dry U.S. tons/day \\
Annual feedstock requirement & $(2,000$ metric t/day $)$ \\
Expected operation time & 724,000 dry U.S. tons/year \\
Equivalent uptime & $7,884 \mathrm{~h} /$ year \\
Facility startup time & $90 \%$ \\
\hline
\end{tabular}

Also consistent with prior recent design cases $[1,3,4,7]$, the delivered feedstock composition is left unchanged (shown in Table 2). More details on historical components used in Aspen Plus for process simulation and their modeled properties may be found in prior design reports [1]. 
Table 2. Delivered Feedstock Composition Assumed in the Present Design

\begin{tabular}{lc}
\hline Component & Composition (dry wt \%) \\
\hline Glucan & 35.1 \\
Xylan & 19.5 \\
Lignin & 15.8 \\
Ash & 4.9 \\
Acetate a & 1.8 \\
Protein & 3.1 \\
Extractives & 14.7 \\
Arabinan & 2.4 \\
Galactan & 1.4 \\
Mannan & 0.6 \\
Sucrose & 0.8 \\
\hline Total structural carbohydrate & 59.0 \\
\hline Total structural carbohydrate + sucrose & 59.8 \\
\hline Moisture (bulk wt \%) & 20.0 \\
\hline groups present in the hemicellulose polymer, converted to acetic acid under low-pH conditions.
\end{tabular}

This report is consistent with previous efforts and communicates results in terms of energy yields in gallons gasoline equivalent (e.g., \$/GGE, GGE/yr, GGE/ton) because the main product of the biorefineries is a fuel compatible with jet fuel and diesel cuts. All yields and MFSPs are normalized to a GGE basis according to their energy content to maintain the consistency of analysis among past and future NREL reports. Lower heating value (LHV) for the fuel product was calculated by an Aspen model and is similar to standard petroleum-equivalent (drop-in hydrocarbon) products [8]. To translate to a GGE basis, a conventional gasoline heating value of 116,090 British thermal units (BTU) per gallon (LHV basis) was considered [8].

\section{Process Design and Cost Estimation Details}

\subsection{Area 100: Feedstock Logistics and Handling}

Feedstock logistics and handling, as well as their impacts on the cost, volume, and quality of the biomass delivered to the biorefinery, are consistent with NREL's 2018 design report, based on inputs furnished by partners at Idaho National Laboratory. Feedstock cost is estimated at $\$ 71.26 /$ dry U.S. ton (2016\$) in this assessment, reflecting future 2030 goals for delivered biomass meeting the composition specifications listed in Table 2. Because this is a significant cost component when determining MFSP, further reductions in feedstock cost should have an important impact in achieving future MFSP goals below $\$ 2.50 / \mathrm{GGE}[1,2]$.

\subsection{Area 200: Pretreatment}

Consistent with NREL's 2018 design report, pretreatment is accomplished through DMR, in which an alkaline extraction operation is utilized to remove acetyl groups, as well as a fraction of lignin, ash, biomass extractives, and other components. In comparison to previous studies centered around deacetylation and dilute acid pretreatment, DMR avoids feeding biomass into a high-pressure reactor, enables an effective ensuing enzymatic hydrolysis, and limits lignin degradation [1]. The latter is especially important in view of the additional purpose of the biorefinery on adding value to lignin in the form of adipic acid. In this design case, the pretreatment starts in a continuous counter-current extraction unit, in which biomass and a caustic solution are fed at opposite ends of a screw conveyor. The extracted solids are dewatered with a screw discharger at one end of the unit (leaving biomass at 
$30 \%$ total solids) and routed to mechanical refining. The caustic exits with the black liquor, which is sent to a base-catalyzed deconstruction step (along with residual downstream lignin solids) and then to aerobic fermentation to muconic acid in Area 700. Following alkaline extraction, DMR uses a twostage mechanical processing operation and a disc refiner, followed by a secondary roller mill to open the biomass structure and render the fibers more available for enzymatic hydrolysis. Table 3 summarizes the main parameters used to model the DMR pretreatment step.

Table 3. DMR Pretreatment Conditions Applied in This Design a

\begin{tabular}{lc}
\hline Parameter & Current Design \\
\hline Deacetylation (mild alkaline extraction) & $92^{\circ} \mathrm{C}$ \\
Temperature & $90 \mathrm{~min}$ \\
Residence time & $70 \mathrm{mg} / \mathrm{g} \mathrm{dry}$ biomass \\
Total caustic (NaOH) loading & $2 \%$ \\
Net solubilized glucan to liquor (wt \%) & $10 \%$ \\
Net solubilized xylan to liquor (wt \%) & $30 \%$ \\
Net solubilized arabinan to liquor (wt \%) & $66 \%$ \\
Ash removal (wt \%) & $100 \%(10 \mathrm{~g} / \mathrm{L})$ \\
Solubilized acetate (wt \%) & $100 \%(79 \mathrm{~g} / \mathrm{L})$ \\
Solubilized extractives (wt \%) & $47 \%(40 \mathrm{~g} / \mathrm{L})$ \\
Solubilized lignin (wt \%) & $30 \%$ \\
Mechanical refining & 200 \\
Solids loading (wt \%) & \\
Power demand (kWh/dry tonne processed biomass) & \\
\hline
\end{tabular}

${ }^{a}$ DMR parameters are generally based on NREL experimental data observed to date on DMR processing with batch deacetylation, but extrapolated to higher targeted black liquor concentrations and marginally lower carbohydrate losses targeted for counter-current deacetylation/alkaline extraction [1].

Costing of the units in Area 200 is kept consistent with the 2018 design report. The counter-current deacetylation unit was costed based on a Braunschweigische Maschinenbauanstalt AG sugar beet cossette extraction unit $[9,10]$. Subsequently for mechanical refining, a total of 8 disc refiner units and 11 roller mill units are utilized with a purchase cost of around $\$ 2.5$ million and $\$ 580,000$ per unit, respectively, based on previous vendor quotations (2013\$).

\subsection{Area 300: Enzymatic Hydrolysis and Hydrolysate Conditioning}

The enzymatic hydrolysis process is depicted in Figure 3, maintaining consistency for the hydrolysis operations with the details reflected in NREL's 2018 design report under the BDO pathway, namely initiating hydrolysis in a 24-hour vertical liquefaction vessel, after which point the material may be more easily mixed and accordingly is transferred to batch-stirred tank reactors. After mixing in the enzyme and associated broth from on-site enzyme production (Area 400), total solids loading into the continuous vessel is maintained at $25 \mathrm{wt} \%$, consistent with prior targets [1]. The material is batched to one of eight 1-million (MM)-gallon agitated vessels (950,000 gal working volume), where enzymatic hydrolysis continues for another 96 hours ( 5 days total hydrolysis time). Temperature is controlled through all hydrolysis operations at $50^{\circ} \mathrm{C}$. In the integrated biorefinery scenario, an additional amount of time (and thus reactor vessels) is devoted to sequential fermentation of sugars to BDO, with the associated additional tankage volume for fermentation allocated to Area 550. Total enzyme loading is targeted at $10 \mathrm{mg}$ enzyme protein/g cellulose (including both cellulase and hemicellulase enzymes) with a target of $90 \%$ conversion of cellulose to glucose and xylan to xylose, as well as $85 \%$ arabinan to arabinose. The target design conditions and yields for enzymatic hydrolysis are summarized in Table 4 . 


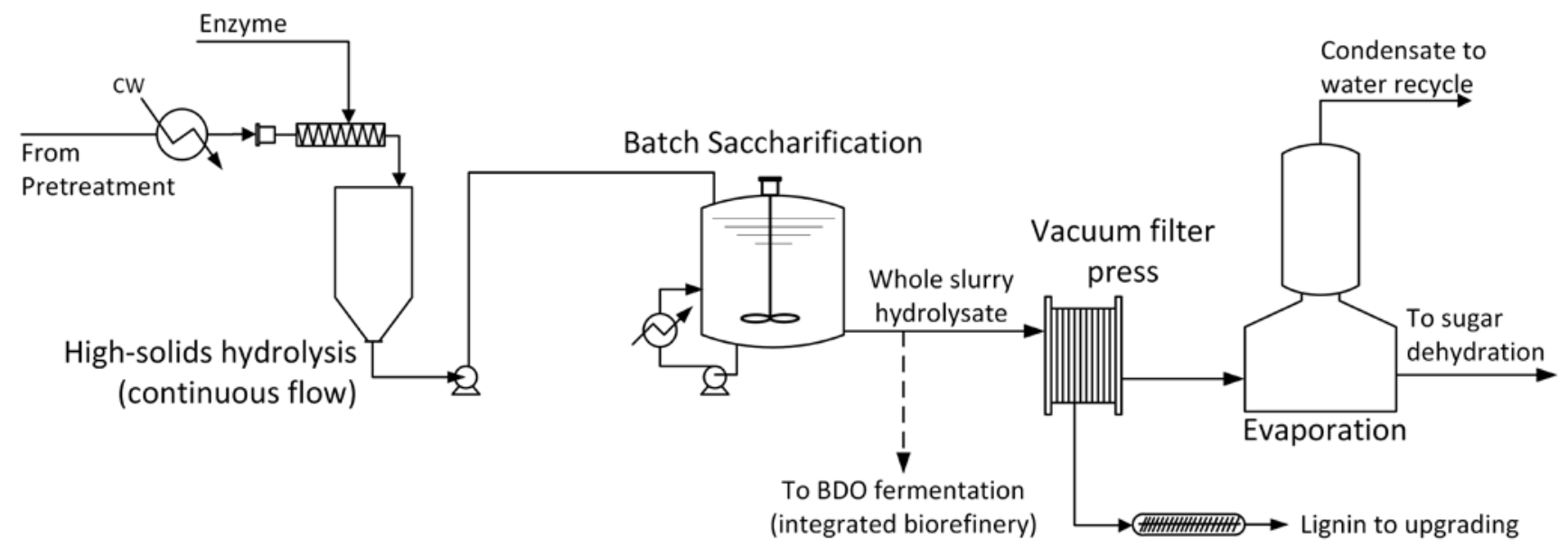

Figure 3. Process schematic diagram for enzymatic hydrolysis and hydrolysate conditioning operations

Table 4. Enzymatic Hydrolysis Conditions and Conversion Targets

\begin{tabular}{ll}
\hline Temperature & $50^{\circ} \mathrm{C}\left(122^{\circ} \mathrm{F}\right)$ \\
Initial solids loading & $25 \mathrm{wt} \%$ total solids \\
Residence time & 5.0 days total $(96 \mathrm{~h})$ \\
Number and size of continuous vessels & $6 @ 950 \mathrm{~m}^{3}(250,000$ gal $)$ each \\
Number and size of batch vessels & $8 @ 3,600 \mathrm{~m}^{3}(950,000$ gal $)$ each \\
Total enzyme (cellulase + hemicellulase) loading & $10 \mathrm{mg}$ protein/g cellulose \\
Conversion: (Glucan $)_{\mathrm{n}}+\mathrm{n} \mathrm{H}_{2} \mathrm{O} \rightarrow \mathrm{n}$ Glucose & $90 \%$ \\
Conversion: (Glucan $)_{\mathrm{n}}+\mathrm{n} \mathrm{H}_{2} \mathrm{O} \rightarrow \mathrm{n}$ Cellobiose & $1.2 \%$ \\
Conversion: (Xylan) $+\mathrm{n} \mathrm{H}_{2} \mathrm{O} \rightarrow \mathrm{n}$ Xylose & $90 \%$ \\
Conversion: (Arabinan $)_{\mathrm{n}}+\mathrm{n} \mathrm{H}_{2} \mathrm{O} \rightarrow \mathrm{n}$ Arabinose & $85 \%$ \\
\hline
\end{tabular}

Following batch saccharification, in the dedicated biorefinery scenario, the full hydrolysate stream is routed through a solids removal step, utilizing a vacuum filter press aided by a flocculant to support cake formation and wash water to support recovery of sugars in the liquor phase. Although costly, this operation is deemed necessary if placed sequentially following enzymatic hydrolysis, reflecting recent experimental learnings regarding the difficulty of filtering solids from DMR-pretreated hydrolysate. The integrated biorefinery case also routes the majority of the hydrolysate through the vacuum filter press operation for subsequent upgrading to furans, but a fraction (roughly 45\%) carries on as raw whole slurry into BDO fermentation in order to generate the MEK co-reactant internally. The vacuum filter press operates at targeted parameters summarized in Table 5, achieving a 95\% net recovery of sugars in the liquor phase (as may be found in NREL's sugar model scenarios available from https://www.nrel.gov/extranet/biorefinery/aspen-models/). The product liquor stream from the vacuum filter press is subsequently concentrated using a multistage mechanical vapor recompression (MVR) evaporator, achieving 49\% sugar concentration (50\% water), ultimately to enable appropriate targeted sugar concentrations in the feed stream to the furan catalytic upgrading reactor after combining with subsequent dioxane/water recycle. To avoid the possibility of sugar degradation at high temperatures [11], the evaporators are assumed to be operated under slight vacuum to keep the maximum temperature below $90^{\circ} \mathrm{C}$. Key parameters for the MVR evaporator are also summarized in Table 6. 
Table 5. Hydrolysate Clarification and Concentration Specifications

\begin{tabular}{ll} 
Clarification: flocculant loading & $20 \mathrm{~g} / \mathrm{kg}$ insoluble solids (IS) \\
Clarification: wash ratio & $10 \mathrm{~L} / \mathrm{kg} \mathrm{IS}$ \\
Clarification: permeance & $15 \mathrm{~kg} \mathrm{IS} / \mathrm{m}^{2}-\mathrm{h}$ \\
Clarification: sugar recovery to liquors & $95 \%$ \\
Concentration: product sugar concentration & $49 \mathrm{wt} \%$ (50\% water, $1 \%$ other solubles) \\
Concentration: maximum operating temperature & $87^{\circ} \mathrm{C}$ \\
Concentration: evaporator technology & $4-\mathrm{stage} \mathrm{MVR}$ \\
Concentration: electricity usage & $5,657 \mathrm{~kW}$ (dedicated case) \\
& $3,191 \mathrm{~kW}$ (integrated case) \\
\hline
\end{tabular}

The cost assumptions for the hydrolysis reactors were maintained with prior NREL studies [1-3], namely empty towers for the continuous hydrolysis reactor based on a vendor quotation for flatbottomed plug-flow reactors with a 10:1 height-to-diameter ratio, as well as 1-MM-gal batch hydrolysis reactors and agitators. As previously noted, in the integrated biorefinery case, the volume and tankage requirements for the batch hydrolysis portion of the process were allocated to Area 300 and additional volume/tank costs for subsequent BDO fermentation were allocated to Area 550. Capital and operating (flocculant) costs for the vacuum filter press and MVR evaporator were based on previous inputs furnished by vendors and engineering subcontractors.

\subsection{Area 400: Enzyme Production}

This process area produces cellulase and hemicellulase enzymes used in Area 300 to hydrolyze cellulose into glucose and xylan/arabinan into xylose/arabinose, respectively. Consistent with earlier design cases, the present design considers aerobic bioconversion of a $T$. reesei-like fungus on a purchased glucose substrate. Also as noted in the 2018 design report, one difference in the present work is that both cellulase and hemicellulase enzymes are required in the enzymatic hydrolysis step, but the same overall enzyme production process framework is maintained, assuming the costs of producing a quantity of enzyme protein are similar whether for cellulase or hemicellulase. The whole broth product is transferred to the hydrolysis tanks without an enzyme isolation step. Figure 5 provides a simplified flow diagram of the enzyme production section.

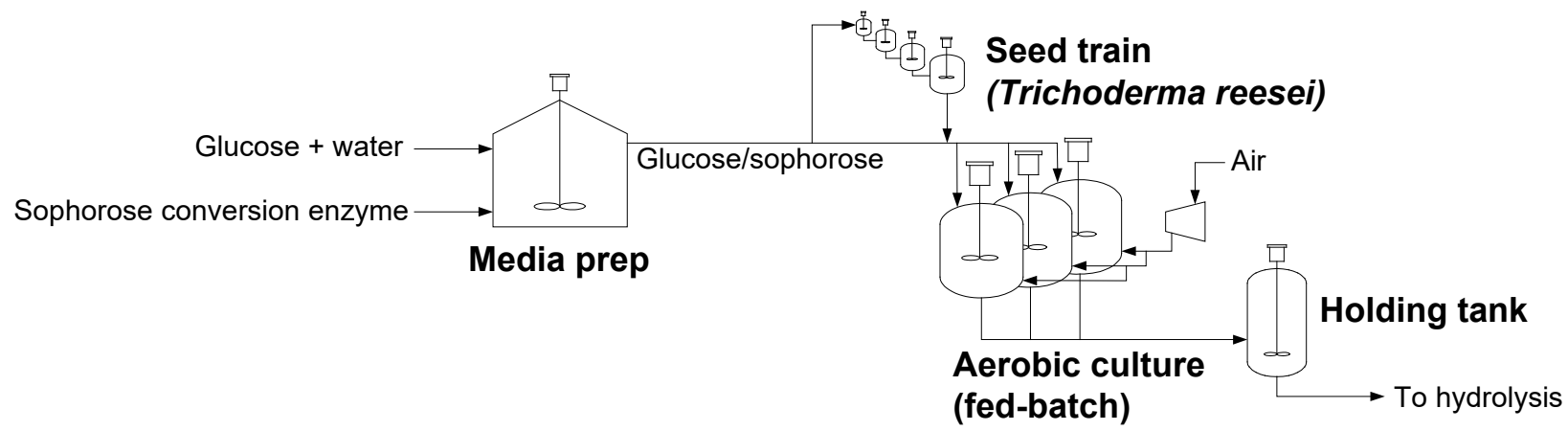

Figure 4. Simplified flow diagram of the enzyme production process

The key assumptions used in the current design are maintained consistently with prior models [1]. The targeted total cellulase and hemicellulase loading to enzymatic hydrolysis is maintained at $10 \mathrm{mg}$ of enzyme protein per gram of cellulose, with an additional 10\% produced to account for a slipstream provided to the media preparation tank. Each production vessel is sized at $300 \mathrm{~m}^{3}$ (80,000 gal), operated in fed-batch between a 50\% initial and 80\% final volume, and with consistent cycle times documented in prior NREL reports. The required number of vessels are set for either biorefinery 
configuration, reflecting a productivity rate of $0.30 \mathrm{~g}$ protein/L-h. Required inputs to support enzyme production are supplied including glucose, corn steep liquor (CSL), ammonia, sulfur dioxide $\left(\mathrm{SO}_{2}\right)$, and corn oil antifoam. Temperature is maintained at $28^{\circ} \mathrm{C}$ using chilled water, and aeration inputs are set to satisfy required oxygen transfer rates based on governing oxygen solubilization considerations discussed previously [2]. Likewise, the inoculum seed train assumptions are also consistent with prior models, making use of four trains with three batch seed fermentors increasing in size from 0.3 to 3 to $30 \mathrm{~m}^{3}$. The aeration demand is assumed to be $10 \%$ of the production aeration rate. The key design parameters, as well as targeted yields for enzyme production, are summarized in Table 6.

Table 6. Enzyme Production Bioreactor Design/Operating Parameters

\begin{tabular}{ll}
\hline Parameter & Assumption \\
\hline Protein loading to enzymatic hydrolysis & $10 \mathrm{mg}$ protein/g cellulose \\
Reactor size & $300,000 \mathrm{~L} @ 80 \%$ final working volume \\
Operating temperature & $28^{\circ} \mathrm{C}$ \\
Enzyme titer at harvest & $50 \mathrm{~g} / \mathrm{L}$ \\
Mass yield of enzyme from glucose & $0.24 \mathrm{~kg}$ enzyme $/ \mathrm{kg}$ glucose \\
Enzyme production cycle time & $120 \mathrm{~h}$ online, $48 \mathrm{~h}$ offline, $168 \mathrm{~h}$ total \\
Total electricity demand per kg protein & $9 \mathrm{kWh} / \mathrm{kg}$ \\
(air compressors, agitators, chillers, pumps) & \\
\hline
\end{tabular}

The cost estimation for all equipment in Area 400 was left unchanged from prior NREL design reports making use of this process area. Quotations for the production bioreactors, internal cooling coils, production agitators and motors, skid-mounted seed fermentors, and air compressor were provided by vendors through a previous engineering subcontract. Not included in the enzyme production model are any costs for concentration, stabilization, or transportation of the enzyme to the plant, which would not be required in this case for on-site production. Applicable licensing fees are not included, with rationale discussed previously for implications such as this and other comparative details relative to externally purchased enzymes [2].

\subsection{Area 500: Furans Production and Upgrading}

\subsubsection{Overview}

Area 500 represents the core portion of the biorefinery of "new" focus in this work, in which sugars (either part of them in the integrated case or the totality of them in the dedicated case) are converted to furans and ultimately to hydrocarbon fuels in a series of catalytic steps.

In short, this is a thermocatalytic process converting sugars to hydrocarbons via furans (furfural and $\mathrm{HMF}$ ) as intermediates. The furans pathway is centered around the catalytic production of furfural and HMF from pentose and hexoses, respectively, contained in clarified corn stover hydrolysate. The sugar dehydration reaction is carried out with a mixture of water and dioxane as a necessary solvent and $\mathrm{AlCl}_{3}$ as the catalyst. The stream containing furfural and $\mathrm{HMF}$ is then mixed with $\mathrm{NaOH}$ and MEK to undergo aldol condensation. The reactional mixture is then sent to a distillation column for dioxane recovery, which yields an aqueous dioxane stream close to its azeotropic composition for recycle. The high-molecular-weight condensates from the bottom of the column are separated from the aqueous phase in a decanter. Finally, furans/MEK condensates are ultimately deoxygenated with $\mathrm{H}_{2}$ in a highpressure catalytic fixed-bed reactor to produce hydrocarbons in the $\mathrm{C}_{14}-\mathrm{C}_{16}$ range. Figure 5 depicts the overall process diagram flow for this area and Figure 6 indicates the reactional steps to reach hydrocarbon fuels starting from hydrolysate sugars. 


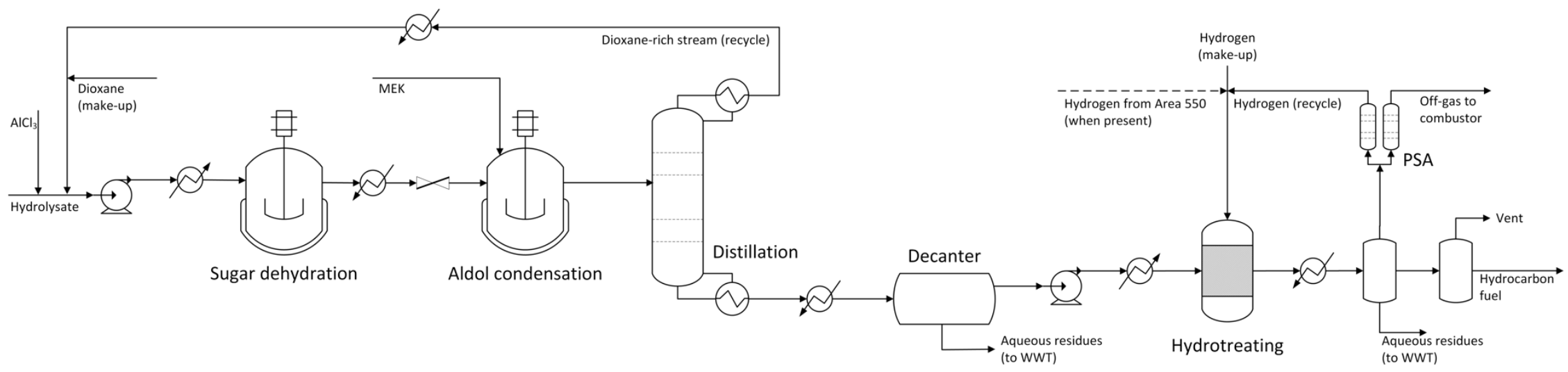

Figure 5. Simplified flow diagram of the furans production and upgrading section

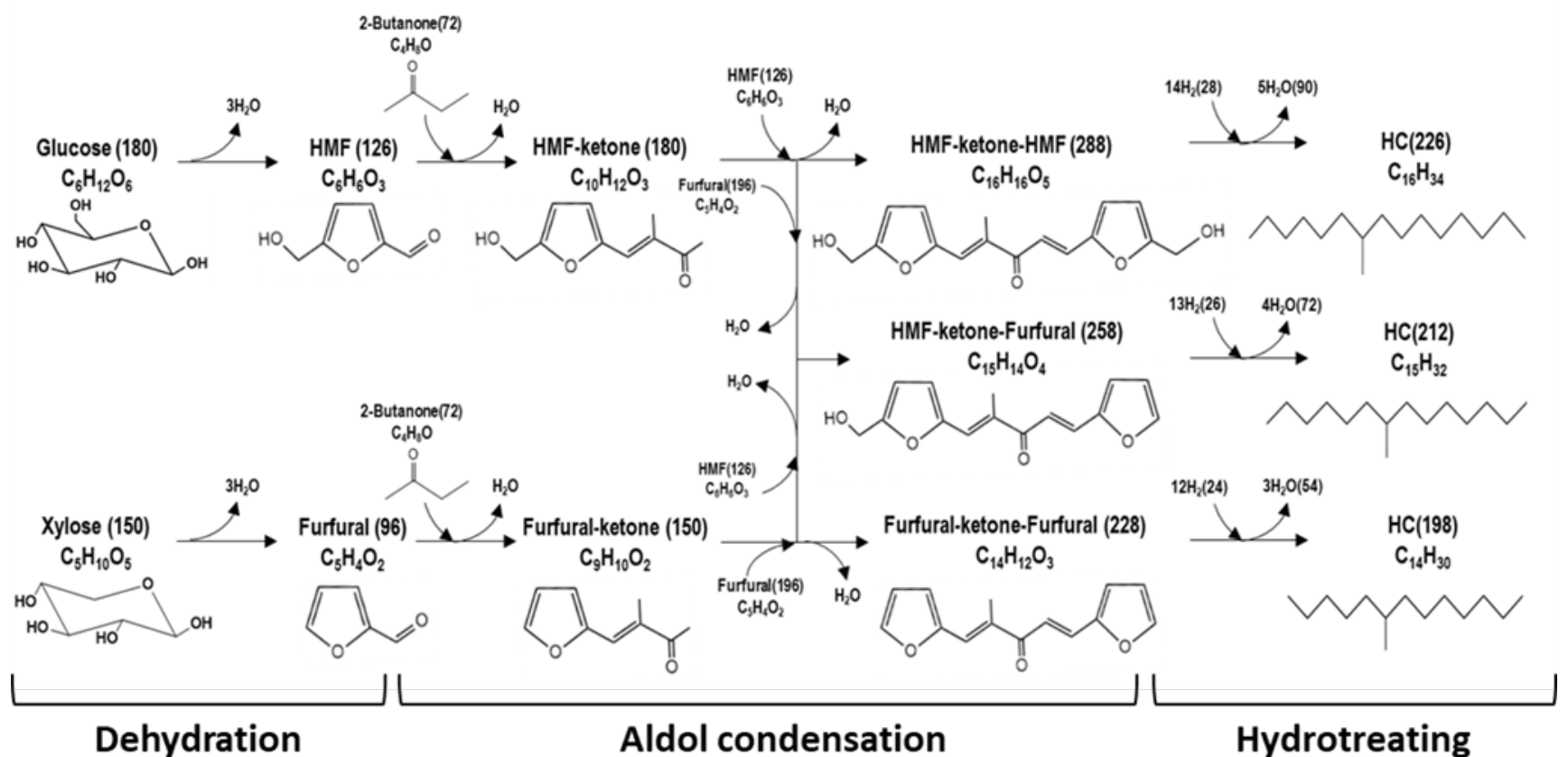

Figure 6. Main reactions taking place in furans production and upgrading section 


\subsubsection{Design Basis}

\section{Sugar Dehydration to Furans}

The catalytic upgrading process starts with the hydrolysate that was conditioned in Area 300 through filtering to remove lignin and concentration via an MVR evaporator. The hydrolysate is concentrated up to a combined sugar fraction of $49 \mathrm{wt} \%$. The analysis showed that there are marginal gains in terms of MFSP for increasing sugar concentration in the hydrolysate stream: passing from $30 \mathrm{wt} \%$ combined sugars up to $40 \mathrm{wt} \%$ reduces MFSP by $\$ 0.03 / \mathrm{GGE}$, whereas increasing it to $49 \mathrm{wt} \%$ means gaining another $\$ 0.05 / \mathrm{GGE}$. It should be highlighted that concentrating the hydrolysate up to $49 \mathrm{wt} \%$ combined sugars corresponds to an actual sugar concentration of $29 \mathrm{wt} \%$ in the dehydration reactor considering the water that is recycled with dioxane after solvent recovery. This is consistent with recent experimental developments that aim at a sugar feed concentration of $30 \mathrm{wt} \%$ for dehydration. The main reasons for this behavior are leaner equipment and lower energy requirements for heating, cooling, and pumping in Area 500. After mixing with the catalyst $\left(\mathrm{AlCl}_{3}\right)$ and dioxane, the stream is pressurized and heated before being fed into the sugar dehydration reactor. The operating conditions for the reactor are based on recent experimental work, including pressure of $24.8 \mathrm{~atm}$ (350 psi), temperature of $230^{\circ} \mathrm{C}, \mathrm{AlCl}_{3}$ utilized in catalytic quantities (1:36 molar ratio to sugars), as well as use of dioxane solvent at a volume ratio in relation to the full aqueous hydrolysate of 1.5:1 to promote high yields to furans. See Table 7 for a summary of the main considered parameters. In the reactor, the sugars are fully converted to the respective furans, both monomers (glucose, xylose, and arabinose) and oligomers (sucrose and cellobiose). At maximum conversion, furfural yield is $64 \mathrm{wt} \%$ and that of HMF corresponds $70 \mathrm{wt} \%$ relative to corresponding sugar feeds. Table 7 also presents the reactions occurring in the reactor and Figure 6 indicates the overall reactional path.

\section{Table 7. Sugar Dehydration Conditions and Conversion Targets}

\begin{tabular}{lr}
\hline Lewis acid $\left(\mathrm{AlCl}_{3}\right)$ loading & $1: 36 \mathrm{~mol} \mathrm{AlCl} / \mathrm{mol}$ sugars \\
Dioxane:hydrolysate ratio (v/v) & $1.5: 1$ \\
Temperature & $230^{\circ} \mathrm{C}$ \\
Pressure & $24.8 \mathrm{~atm}(350 \mathrm{psi})$ \\
Reaction time & $5 \mathrm{~min}$, continuous \\
Catalyst lifetime & $\mathrm{N} / \mathrm{A}$ (homogeneous) \\
Conversion: Glucose $\rightarrow \mathrm{HMF}+3 \mathrm{H}_{2} \mathrm{O}$ & $100 \%$ (glucose) \\
Conversion : Xylose $\rightarrow$ Furfural $+3 \mathrm{H}_{2} \mathrm{O}$ & $100 \%$ (xylose) \\
Conversion: Arabinose $\rightarrow$ Furfural $+3 \mathrm{H}_{2} \mathrm{O}$ & $100 \%$ (arabinose) \\
\hline
\end{tabular}

\section{Aldol Condensation}

The reactional mixture produced from the first step is conditioned through cooling and pressure reduction down to conditions required in the aldol condensation reaction $\left(60^{\circ} \mathrm{C}\right.$ and atmospheric pressure). $\mathrm{NaOH}$ is used as the catalyst and MEK is the ketone of choice to react with furfural and HMF (although other ketones are possible for this step as well). Both compounds are mixed before being routed to the reactor. The condition at which MEK is delivered to the aldol condensation reaction differs according to the setup of the biorefinery. In the dedicated case, MEK is considered to be purchase externally, entering the process at $99 \%$ purity (though such a high purity is not needed for this operation). On the other hand, in the integrated biorefinery, MEK is alternatively sourced from Area 550 and routed to the aldol condensation at $84.9 \mathrm{wt} \%$ purity, close to its azeotropic composition with water. This approach was chosen to avoid an azeotropic distillation setup in Area 550, thus minimizing CAPEX and energy consumption for the recovery of MEK. Besides, the distillation column for dioxane recovery after the aldol condensation reactions is able to handle the amount of 
water brought by the MEK-rich stream from Area 550. The full approach for separating MEK from water and minor coproducts from BDO dehydration is discussed in detail in Section 3.6.2.

Table 8 summarizes the main conditions employed in the aldol condensation reaction. It is important to highlight that the reaction reaches already high conversions in a relatively short time (around 20 $\mathrm{min}$ ), but the total reaction time is set at $60 \mathrm{~min}$ to ensure the full conversion of furans into condensates. The furans/MEK condensates are formed by combining one MEK molecule and either two furfural molecules (F-MEK-F), two HMF molecules (H-MEK-H), or one of each furan (H-MEKF). The reactional path is indicated in Figure 6, and Table 8 also presents the reactions considered in the simulations. MEK requirements are tailored to ensure full conversion of furans and eliminate residual MEK in the outlet stream of the reactor.

Table 8. Aldol Condensation Conditions and Conversion Targets

\begin{tabular}{lr}
\hline Conversion & $100 \%$ \\
Catalyst & $\mathrm{NaOH}$ (homogeneous) \\
Residence time & $60 \mathrm{~min}$ \\
Temperature & $60^{\circ} \mathrm{C}$ \\
Pressure & $1 \mathrm{~atm}$ \\
NaOH loading & $3.6 \mathrm{~g} / \mathrm{L}$ \\
Conversion: 2 HMF $+\mathrm{MEK} \rightarrow \mathrm{H}-\mathrm{MEK}-\mathrm{H}+2 \mathrm{H}_{2} \mathrm{O}$ & $28 \%$ (MEK) \\
Conversion: 2 Furfural $+\mathrm{MEK} \rightarrow \mathrm{F}-\mathrm{MEK}-\mathrm{F}+2 \mathrm{H}_{2} \mathrm{O}$ & $8 \%$ (MEK) \\
Conversion: $\mathrm{HMF}+\mathrm{Furfural}+\mathrm{MEK} \rightarrow \mathrm{H}-\mathrm{MEK}-\mathrm{F}+2 \mathrm{H}_{2} \mathrm{O}$ & $64 \%$ (MEK) \\
\hline
\end{tabular}

\section{Dioxane Recovery}

After aldol condensation, the reactional mixture contains mainly water, dioxane, furans/MEK condensates, and other minor solutes, namely $\mathrm{AlCl}_{3}$ and $\mathrm{NaOH}$. Because the process is dependent on large amounts of dioxane as a cosolvent, it is imperative to recycle it to the inlet of the sugar dehydration reactor while keeping dioxane makeup to a minimum. The proposed configuration for dioxane recovery nearly avoids dioxane losses and minimizes impurities in the dioxane recycle stream. The distillation column (depicted in Figure 5) is designed to recover $99.9 \%$ of the dioxane at approximately $78 \mathrm{wt} \%$ purity. These performance targets were deemed as optimal to avoid overburdening the distillation column with a high reflux ratio and therefore a high energy consumption. A preliminary setup including a second column with an extractive distillation using benzene as the entrainer was assessed to determine the feasibility of recovering and recycling dioxane at a higher purity $(97.5 \mathrm{wt} \%)$. This configuration resulted in much larger heating and cooling demands and in the purchase of large quantities of external boiler fuel, which ultimately led to it being dropped from the final version of either biorefinery approach in favor of including some water in the recycle.

After dioxane removal from the reactional mixture at the top of the distillation column, the bottoms are routed to a decanter, in which the heavy furans/MEK condensates are easily separated from the aqueous phase. While the heavy organic molecules are sent to hydrotreating, the aqueous phase is sent to WWT (Area 600). NaOH added to the reaction and still present in this stream is partially recovered as sodium sulfate after treatment with $\mathrm{H}_{2} \mathrm{SO}_{4}$. $\mathrm{AlCl}_{3}$ used as the catalyst in the sugar dehydration reaction is not recovered or removed prior to aldol condensation, being routed to Area 600 for disposal. 


\section{Catalytic Upgrading to Hydrocarbons}

In the hydrotreating section, the condensates are pressurized and heated up to the conditions required by the final hydrotreating step. These compounds undergo deoxygenation over a Pd catalyst (supported by $\mathrm{Al}_{2} \mathrm{O}_{3} / \mathrm{SiO}_{2}$ ) at a weight hourly space velocity (WHSV) of $2 \mathrm{~h}^{-1}$ with $\mathrm{H}_{2}$ in stoichiometric excess to yield hydrocarbons. In the target case, all condensates are converted via hydrodeoxygenation, meaning that no $\mathrm{CO}_{2}$ is lost through decarboxylation. The reactor outlet stream is routed to a flash vessel for degassing; gases are then sent to a pressure swing adsorption (PSA) unit to maximize $\mathrm{H}_{2}$ recovery for recycling $\left(95 \%\right.$ recovery of surplus $\left.\mathrm{H}_{2}\right)$. The tail gas from the PSA is burned in a dedicated furnace to partially supply the energy requirements of the hydrotreating feed heating section. Finally, the resulting hydrocarbons, mainly isoparaffins in the range of $\mathrm{C}_{14}$ to $\mathrm{C}_{16}$, are dried and sent to storage. Table 9 summarizes the main conditions of the hydrotreating reactor and the reactions that take place.

Table 9: Hydrotreating Conditions and Conversion Targets

\begin{tabular}{lr}
\hline Conversion & $100 \%$ \\
Catalyst & $1 \% \mathrm{Pd} / \mathrm{Al}_{2} \mathrm{O}_{3}-\mathrm{SiO}_{2}$ \\
WHSV & $2 \mathrm{~h}^{-1}$ \\
Temperature & $300^{\circ} \mathrm{C}$ \\
Pressure & $98.7 \mathrm{~atm}$ \\
Hydrodeoxygenation (HDO) vs. decarbonylation & $100: 0$ \\
Hydrocarbon fuel composition & $\mathrm{C}_{14}-\mathrm{C}_{16}$ branched hydrocarbons \\
Conversion: H-MEK-H $+14 \mathrm{H}_{2} \rightarrow \mathrm{C}_{16} \mathrm{H}_{34}+5 \mathrm{H}_{2} \mathrm{O}$ & $100 \%(\mathrm{H}-\mathrm{MEK}-\mathrm{H})$ \\
Conversion: F-MEK-F $+12 \mathrm{H}_{2} \rightarrow \mathrm{C}_{14} \mathrm{H}_{30}+3 \mathrm{H}_{2} \mathrm{O}$ & $100 \%(\mathrm{~F}-\mathrm{MEK}-\mathrm{F})$ \\
Conversion: $\mathrm{H}-\mathrm{MEK}-\mathrm{F}+13 \mathrm{H}_{2} \rightarrow \mathrm{C}_{15} \mathrm{H}_{32}+4 \mathrm{H}_{2} \mathrm{O}$ & $100 \%(\mathrm{H}-\mathrm{MEK}-\mathrm{F})$ \\
\hline
\end{tabular}

\subsubsection{Cost Estimation}

Processing in Area 500 occurs in some central pieces of equipment, namely the three reactors for sugar dehydration, aldol condensation, and hydrotreating. The sugar dehydration reactor is dimensioned for a 5 -min residence time. The base equipment is a 30,000-gal tubular flow reactor able to withstand high pressures and temperatures estimated at $\$ 16.3 \mathrm{MM}(2013 \$)$. The aldol condensation reaction is set at $60 \mathrm{~min}$ and the base reactor for scaling is a 200,000-gal, atmospheric pressure vessel estimated at $\$ 1.2$ MM (2009\$). Finally, the hydrotreating operation is based on an HDO reactor from previous efforts [1]. The base unit is costed at $\$ 6.5 \mathrm{MM}(2011 \$)$ for a liquid flow of 33,000 L/h.

The dioxane recovery column, as well as the decanter, were costed using ACCE. Other auxiliary units (pumps, heaters, compressors, PSA unit) were retrieved from previous NREL cost databases and scaled accordingly. The full equipment list and the installed costs for the items in each biorefining approach (dedicated or integrated) after scaling can be found in Appendix A.

\subsection{Area 550: MEK Production}

\subsubsection{Overview}

Area 550 includes all processing steps for conversion of a fraction of sugars in the hydrolysate to BDO via biological conversion (anaerobic fermentation), as well as catalytic upgrading of this intermediate to MEK and its recovery. As noted, Area 550 is only included for the integrated biorefinery scenario to fully reflect the economic implications for a single 2,000-tonne/day biorefinery configured to coproduce both the furan and MEK intermediates together, while MEK is purchased in the dedicated case. 
In the BDO pathway, after batch enzymatic hydrolysis is completed, the hydrolysate is cooled and batch fermentation is initiated in the same vessels utilizing the whole hydrolysate slurry with solids. BDO fermentation utilizes an engineered strain of Zymomonas mobilis to convert sugars to 2,3-BDO plus hydrogen as a byproduct for achieving cell redox balancing (the latter is purified from the fermentation off-gas and used in Area 500 to help meet catalytic upgrading hydrogen demands). The fermentor product broth is routed to a lignin press to remove solids, and then to a polishing filter to remove particle fines and ion exchange to mitigate ionic/salt species that may be problematic for the downstream catalyst. The aqueous BDO stream is then heated at elevated pressure and routed to catalytic BDO upgrading, producing MEK and minor byproducts (following guidance from Pacific Northwest National Laboratory [PNNL] collaborators focused on this BDO-to-MEK pathway). The MEK product is recovered in a series of distillation columns and sent to Area 500 to be employed as a reactant in the aldol condensation of furans. Figure 7 depicts the schematic for this process.

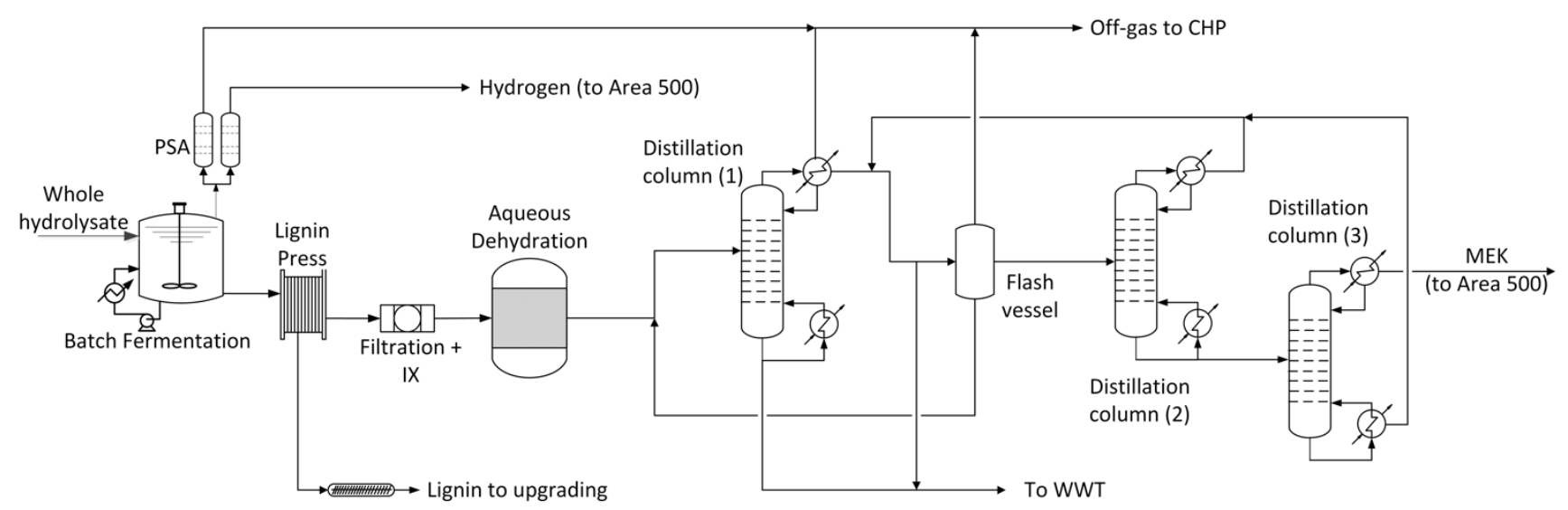

Figure 7. Simplified flow diagram of BDO fermentation, catalytic upgrading to MEK, and ketone recovery in the integrated biorefinery

\subsubsection{Design Basis \\ Fermentation/Product Recovery: BDO}

All details for the BDO fermentation and broth clarification/cleanup steps are identical to those documented in the 2018 design report, but at lower throughput scales based on a fraction of the hydrolysate sugars dedicated to this train in parallel to the furan synthesis train. In summary, an engineered strain of the fermenting bacterium $Z$. mobilis converts glucose, xylose, and arabinose sugars to 2,3-BDO, following similar details as NREL's previous models for ethanol fermentation using this organism [2]. However, in contrast to ethanol fermentation, in order for 2,3-BDO fermentation to be performed fully anaerobically, hydrogen is coproduced to satisfy cell redox balances, which is separated from the fermentor vent stream using a PSA unit and routed for use in Area 500. Additionally, given less toxicity tolerance sensitivity to BDO than ethanol, BDO fermentation is configured to achieve a target titer near $100 \mathrm{~g} / \mathrm{L}$ based on maintaining elevated enzymatic hydrolysis solids concentration targets of $25 \mathrm{wt} \%$ upstream, with resultant hydrolysate processed through fermentation without solids removal.

BDO fermentation is performed in the same 1-MM-gallon agitated batch vessels as used for enzymatic hydrolysis, after cooling to $32^{\circ} \mathrm{C}$ (but as noted, the extra tankage volume and associated costs for fermentation are allocated to Area 550 beyond enzymatic hydrolysis tankage under Area 300). The process targets overall sugar utilizations of $95 \%, 90 \%$, and $85 \%$ for glucose, xylose, and arabinose, 
respectively (as well as 95\% utilization of the biomass sucrose), translating to a targeted process yield of $0.47 \mathrm{~g} \mathrm{BDO} / \mathrm{g}$ total sugars over a 1.5-day fermentation batch time. The assumptions for seed train design and conversions are also maintained consistently with the details documented in the 2018 design report, in turn reflective of seed train logistics for $Z$. mobilis cell mass inoculum production described in the 2011 ethanol report [2]. Namely, 10\% of the hydrolysate to Area 550 is split to inoculum growth consisting of two trains of five reactors each, increasing in size up to 200,000 gal $\left(757 \mathrm{~m}^{3}\right)$ operated in 24 -hour batch cycles. The product from the seed train is recombined with the remainder of the hydrolysate for bioconversion in the main production fermentor vessels to BDO, after also accounting for a standard 3\% loss of sugars to contamination represented as lactic acid. All key BDO fermentation conditions and parameters are summarized in Table 10.

Table 10. BDO Fermentation Conditions and Conversion Targets

\begin{tabular}{|c|c|}
\hline $\begin{array}{l}\text { Organism } \\
\text { Temperature } \\
\text { Initial fermentation solids level }\end{array}$ & $\begin{array}{r}\text { Recombinant } Z \text {. mobilis } \\
32^{\circ} \mathrm{C}\left(96^{\circ} \mathrm{F}\right) \\
25 \% \text { total solids }\end{array}$ \\
\hline Initial fermentation solids level & \\
\hline Residence time & $\begin{array}{r}.5 \text { days }(36 \mathrm{~h})=2.6 \mathrm{~g} / \mathrm{L}-\mathrm{h} \\
\text { productivity }\end{array}$ \\
\hline Inoculum level & $10 \mathrm{vol} \%$ \\
\hline Inoculum production: number of seed trains & 2 \\
\hline Inoculum production: number of batch stages & 5 \\
\hline Inoculum production: maximum stage volume & $200,000 \mathrm{gal}\left(757 \mathrm{~m}^{3}\right)$ \\
\hline Conversion: Glucose $\rightarrow \mathrm{BDO}+\mathrm{H}_{2}+2 \mathrm{CO}_{2}$ & $95 \%$ \\
\hline Conversion: Glucose $+0.047 \mathrm{CSL}+0.018 \mathrm{DAP}$ a $\rightarrow 6$ Z. mobilis $+2.4 \mathrm{H}_{2} \mathrm{O}$ & $2 \%$ \\
\hline Conversion: 6 Xylose $\rightarrow 5 \mathrm{BDO}+5 \mathrm{H}_{2}+10 \mathrm{CO}_{2}$ & $90 \%$ \\
\hline Conversion: Xylose + $0.039 \mathrm{CSL}+0.015 \mathrm{DAP} \rightarrow 5 \mathrm{Z}$. mobilis $+2 \mathrm{H}_{2} \mathrm{O}$ & $1.9 \%$ \\
\hline Conversion: 6 Arabinose $\rightarrow 5 \mathrm{BDO}+5 \mathrm{H}_{2}+10 \mathrm{CO}_{2}$ & $90 \%$ \\
\hline Conversion: Arabinose $+0.039 \mathrm{CSL}+0.015 \mathrm{DAP} \rightarrow 5 \mathrm{Z}$. mobilis $+2 \mathrm{H}_{2} \mathrm{O}$ & $1.9 \%$ \\
\hline Overall BDO process yield, g/g sugars & 0.47 \\
\hline
\end{tabular}

Following completion of the fermentation batch cycle, the fermentor broth is routed to a clarification step, employing a lignin press to remove lignin and other residual solids, utilizing consistent assumptions as the 2011 ethanol design report for this operation as was used to clarify ethanol beer stillage [2]. This step achieves $98 \%$ removal of insoluble solids and reduces water content in the solid material from 80 to $25 \mathrm{wt} \%$; however, it also incurs a small $3 \%$ loss of BDO product. The majority of the Zymomonas biomass is also removed here, which is routed to the boiler and incinerated (as necessary for engineered organism destruction). Recent experimental efforts have suggested that the use of this low-cost lignin press may prove challenging for removal of solids (whether before or after fermentation) based on DMR pretreatment upstream and resulting small particle sizes that make filtration difficult. At present, this unit is maintained for consistency with the published TEA model details for the baseline BDO pathway in the 2018 design report, but this may be revisited moving forward, at which point for this pathway it may be more sensible to process the entire hydrolysate through the vacuum filter press (utilized for furan synthesis in Area 500), which also may allow for more flexibility in subsequent BDO fermentation approaches as may utilize clarified sugars through fed-batch processing to further increase BDO titers.

\section{Catalytic Upgrading: BDO to MEK}

The clarified BDO fermentation broth is further purified across a polishing filter (microfilter) to remove particle fines, followed by ion exchange to remove soluble cations and anions that may 
otherwise deactivate downstream catalysts. These operations were maintained here based on subcontractor guidance during NREL's 2015 catalytic upgrading design case focused on catalytic aqueous-phase reforming of sugars to fuels [4], where they were deemed necessary to ensure catalyst protection at least in the context of those reactor systems. The polishing filter consists of parallel crossflow microfiltration skids with a pore size of 0.1 microns. The filtrate is routed to ion exchange for further purification. A separate-bed ion exchange system is utilized to remove a range of ionic species. Two resin bed trains are included-one for anions and one for cations. There are two units installed in parallel to allow for regeneration of the resin, which is assumed to be required every 17 hours [1]. Resin is regenerated with acid and caustic. An additional 1\% loss of BDO is assumed across the combination of these two purification steps. The purified stream is then routed to BDO upgrading.

The 2,3-BDO product may undergo catalytic upgrading either based on high-purity or bulk aqueous catalysis. The former would be preferred from a capital cost and energy standpoint for catalytic upgrading, but traditional BDO purification requires energy-intensive distillation to boil all the water off (roughly 90\%) from the higher-boiling BDO component, which would incur unacceptably high heat demands. The Bioprocessing Separations Consortium (https://www.bioesep.org/) is conducting research in part focused on more cost- and energy-efficient ways to concentrate BDO, with future cost-trade-off studies planned to evaluate economic impacts between separation costs versus savings in catalytic upgrading. At present, aqueous catalytic upgrading is assumed, making use of the full clarified fermentation broth directly without BDO concentration, consistent with the BDO upgrading pathway documented in the 2018 design case.

For 2,3-BDO aqueous catalytic upgrading to MEK, bifunctional solid acid catalysts are used. This pathway is currently under investigation by PNNL under CUBI. The model for this process has been built based on inputs furnished by PNNL researchers for consistency purposes. In the present design, the aqueous BDO stream containing roughly $10 \mathrm{wt} \% \mathrm{BDO}, 88 \mathrm{wt} \%$ water, and $2 \mathrm{wt} \%$ other components (primarily unconverted sugars) is considered to be converted adiabatically to dehydration intermediates over a heterogeneous catalyst [12]. The composition of products is dependent on the composition of the feed stream, the reaction temperature and pressure, space velocity, and catalyst type. The catalyst considered in this TEA effort is an acid-based one, such as one supported by $\mathrm{SiO}_{2}$ $\mathrm{ZrO}_{2}$ or zeolite. As shown in Table $11,100 \%$ of the BDO is converted to MEK, isobutanol, 1,3butadiene, isobutanol, and 3-buten-2-ol. Stoichiometric element balances are closed with water, $\mathrm{CO}_{2}$, and $\mathrm{O}_{2}$ formation, with model convergence based on the NRTL property package given the presence of oxygenated/polar components (this is the default property package in most of the biochemical model steps for both fuel train pathways).

Table 11. Product Distribution of the 2,3-BDO Upgrading Reaction (Future targets at high conversion and selectivity to desired alkenes); based on inputs from PNNL [13]

\begin{tabular}{lc}
\hline Compound & Yield (mol\%) \\
\hline $\mathrm{MEK}$ & 80.3 \\
Isobutanol & 9.7 \\
1,3-butadiene & 3.1 \\
Isobutanal & 3.2 \\
3-buten-2-ol & 3.2 \\
$\mathrm{CO}_{2}$ & 2.0 \\
$\mathrm{H}_{2} \mathrm{O}$ & 95.4 \\
$\mathrm{O}_{2}$ a & 2.1 \\
\hline${ }^{a} \mathrm{O}_{2}$ added in small amounts for \\
mass balance closure purposes
\end{tabular}


Key reaction parameters are summarized in Table 12 . Pressure was set at $250^{\circ} \mathrm{C}$ in the reactor as a future target condition (the biorefinery is virtually unaffected by changing the reaction temperature to $280^{\circ} \mathrm{C}$ [current experimental condition], as discussed in Section 5.2.2). In a similar way, pressure is not a critical parameter to the reaction and was set at $10 \mathrm{~atm}$. Detailed costs are presented in Section 4.2.

Table 12. 2,3-BDO Catalytic Upgrading Reactor Conditions

\begin{tabular}{lc}
\hline Parameter & Operating Condition \\
\hline Operating temperature & $250^{\circ} \mathrm{C}$ \\
Operating pressure & $1 \mathrm{~atm}$ \\
WHSV $\left(\mathrm{h}^{-1}\right)^{\text {a }}$ & $0.24 \mathrm{~h}^{-1}$ \\
Catalyst type & Copper-based catalysts $\mathrm{Cu} / \mathrm{SiO}_{2}-\mathrm{ZrO}_{2}, \mathrm{Cu} /$ zeolite \\
Catalyst lifetime & 2 years \\
\hline a WHSV of $0.24 \mathrm{~h}^{-1}$ refers to $2,3-\mathrm{BDO}$ only $\left(2.4 \mathrm{~h}^{-1}\right.$ for the full 2,3-BDO- \\
containing stream
\end{tabular}

The MEK product from the BDO catalytic upgrading step is sent to a series of distillation columns and a liquid-liquid separation to separate the MEK from water and the other byproducts of the reaction. This separation step was modeled using the NRTL model and the Redlich-Kwong equation (NRTL$\mathrm{RK}$ ) property method to properly reflect the azeotropes between water/MEK, water/isobutyraldehyde, and water/isobutanol. Figure 8 presents an overview of the three-step distillation system designed to achieve the required MEK recovery for further use in Area 500.

\subsubsection{Cost Estimation}

As noted, BDO fermentation takes place in the same physical vessels as hydrolysis (sequential hydrolysis and fermentation, similar to the 2011 ethanol case) - utilizing the 1-MM-gal batch-stirred tank bioreactors. However, for cost allocation purposes, the fraction of total batch time and associated volume spent in fermentation is allocated to Area 550 and vice versa for hydrolysis allocated to Area 300. All design/cost details for the main fermentation and seed equipment are described in the 2011 ethanol design report; briefly, the large 1-MM-gal fermentors, seed fermentors (including cooling coils), seed hold tank, and lignin press were quoted previously by vendors.

A filtered hydrolysate storage tank with a residence time of 20 minutes is included to provide intermediate storage for filtrate from the belt filter. The clarified BDO polishing filtration system includes two parallel skid microfiltration units, including clean-in-place system and backwash. The ion exchange system uses a separate-bed configuration, with strong acid cation and weak base anion resins based on scaling from cost quotations provided by an engineering subcontractor in NREL's 2015 design case (the provided cost did not break out equipment versus resin cost details separately).

The 2,3-BDO upgrading reactor cost is based on the aqueous phase reforming reactor in NREL's 2015 catalytic upgrading design case [4], sized based on the total aqueous flow rate into the reactor. The reactor operation consists of packed-bed pressure vessels, clad in $317 \mathrm{~L} \mathrm{SS}$, and includes internals that support the catalyst and distribute the process fluid. Finally, equipment used in MEK recovery (distillation columns and flash vessel) were costed using ACCE, and auxiliary units (pumps and heaters) were fetched from previous NREL design reports. 


\subsection{Area 600: Wastewater Treatment}

Wastewater is generated in the process from condensed pretreatment flash vapor in Area 200, the fermentation broths in Areas 550 and 700 (after separation of product and cells), water removed from separations within Area 500 (including water generated during catalytic upgrading reactions), and minor sources such as boiler and cooling tower blowdown. All such wastewater is sent to the WWT system in Area 600. After treatment, the effluent water is assumed clean and fully reusable by the process, reducing both the fresh makeup water requirement and discharge to the environment. All assumptions pertaining to WWT are maintained consistently with the 2018 design report. This also includes the prior justification to remove the anaerobic digestion unit, in light of much lower chemical oxygen demand loading in the combined WWT feed stream relative to prior designs, driven primarily by high utilization of sugars in the fuel train as well as lignin and unconverted organics in the lignin train, leaving lower residual organic matter to be processed through WWT. The updated simplified flow diagram is shown in Figure 8.

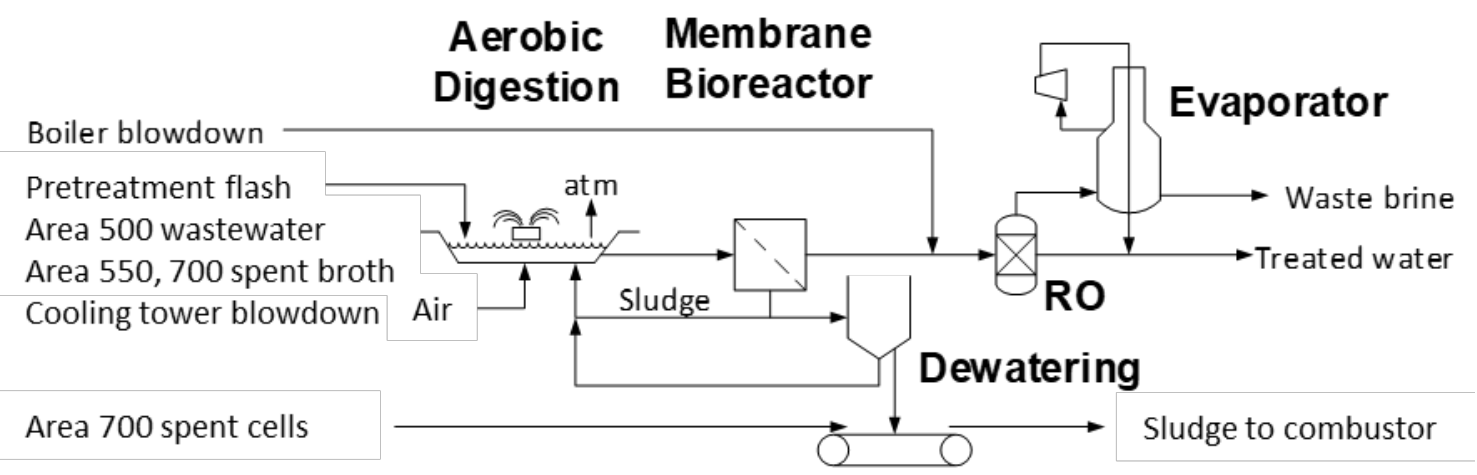

Figure 8. Simplified flow diagram of the WWT process

The aerobic system comprises several large basins or ponds that are aerated from the bottom via a grid sparger, removing $96 \%$ of soluble organic matter and converted to water, $\mathrm{CO}_{2}$, and cell mass. The water in the basins is continuously cycled through membrane bioreactors, which are aeration tanks with ultrafiltration membranes that yield a clean water stream and a low-solids biomass sludge stream, which is mostly recycled to the basin. The wasted fraction of sludge that is not recycled passes first through a gravity belt thickener, then is subsequently centrifuged to $>20 \%$ solids. The resulting digester sludge is routed to the boiler. The water effluent of the membrane system is sufficiently clean to feed directly to reverse osmosis to remove dissolved salts. The reverse osmosis permeate is recycled to the process and the reverse osmosis retentate is concentrated in an evaporator to produce a brine (sodium sulfate salt), sold in this design as a coproduct after further drying and crystallization. The evaporator condensate is combined with the reverse osmosis permeate for reuse in the process.

In previous NREL design reports, the individual unit costs were scaled to either the hydraulic flow rate or chemical oxygen demand load to anaerobic digestion. Similar to the 2018 design case, with the removal of the anaerobic digestion unit, the basis flows for costing were readjusted to reflect the appropriate feed location entering the aerobic digester. Additional equipment costs for sodium sulfate purification were scaled from a recent subcontract with Nexant for an evaporation flash drum, dryer, and centrifuge designed for this purpose. 


\subsection{Area 700: Lignin Upgrading}

This process area includes the key unit operations for deconstruction and conversion of lignin (and other residual biomass components) to coproducts, as a critical element to enabling future MFSP targets. Similar to other operations outside of Areas 500/550, the lignin utilization process was maintained consistently with the 2018 design report, with more extensive documentation of all operations and assumptions documented there [1]. In summary, the black liquor product from DMR pretreatment is combined with the residual solids stream from the vacuum filter press and (in the integrated biorefinery case) solids from BDO fermentor broth clarification and routed to a more severe "base-catalyzed deconstruction" (BCD) unit employing a caustic soaking process at elevated temperature to further deconstruct high-molecular-weight lignin to metabolically accessible compounds. The caustic from DMR pretreatment that exits with the black liquor offsets a large portion of the caustic required to achieve the elevated $\mathrm{pH}$ in the BCD step. The soluble liquid BCD product is then routed to bioconversion, which converts soluble lignin and other residual organics to muconic acid through an aerobic pH-controlled bioconversion with Pseudomonas putida. The product is initially produced as a muconate salt at the given fermentation $\mathrm{pH}$ (i.e., the caustic from DMR/BCD neutralizes muconic acid to maintain near-neutral $\mathrm{pH}$, forming sodium muconate), which is then isolated in high purity as muconic acid crystals following acid addition and low-pH crystallization. The muconic acid crystal is redissolved in a carrier solvent (ethanol) and hydrogenated under mild conditions to adipic acid, which is subsequently recovered through another crystallizer. A schematic diagram for the process is shown in Figure 9.

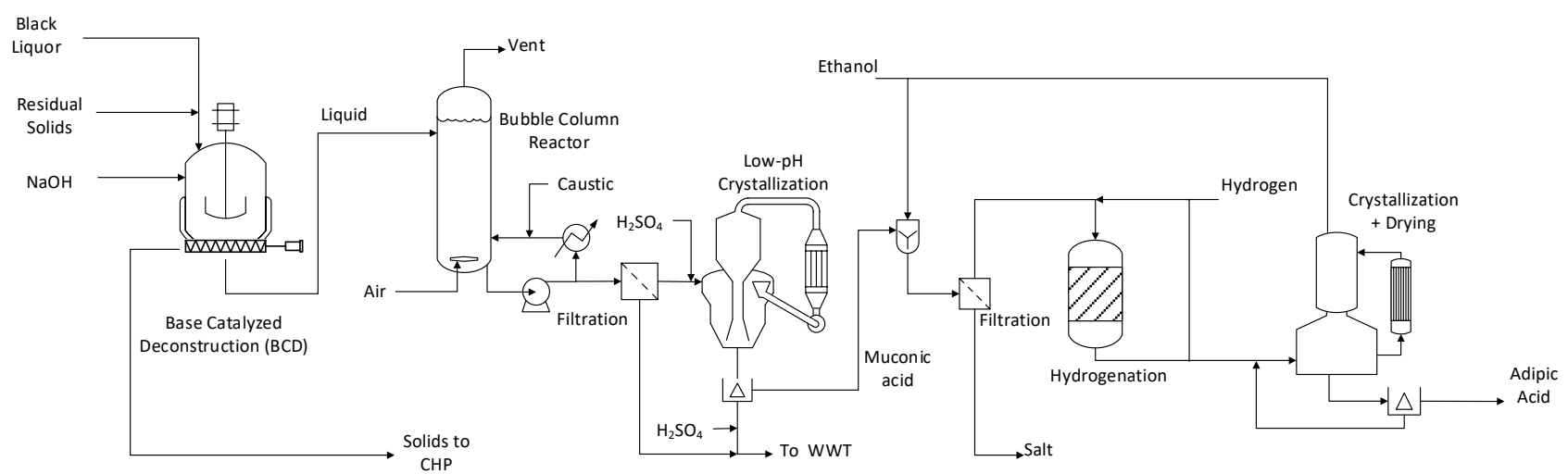

Figure 9. Schematic diagram of lignin deconstruction and conversion process to coproducts

In the $\mathrm{BCD}$ step, caustic $(\mathrm{NaOH})$ is required at a minimum of $2 \mathrm{wt} \%$ loading based on the combined black liquor/residual solids feed mixture. Similar to the 2018 design case, after accounting for the amount of caustic provided in deacetylation upstream, the combined BCD feed stream has a caustic loading of $5.1 \%$, in excess of the $2 \%$ threshold, and no additional caustic is needed. The treated mixture is pressurized to $6.3 \mathrm{~atm}$, then reacted for 30 minutes at a temperature of $120^{\circ} \mathrm{C}$ (though higher temperatures may be reflected in the future if found to support better lignin deconstruction). In keeping with the 2018 design basis, $36 \mathrm{wt} \%$ of the solids entering the BCD reactor are solubilized to metabolically accessible monomers/oligomers. Of the solids present, this includes $48 \mathrm{wt} \%$ solubilization of carbohydrates and $53 \mathrm{wt} \%$ of the lignin. Residual solids are separated and sent to the boiler, while the solubilized product is cooled and then routed to fermentation. Table 13 summarizes the $\mathrm{BCD}$ reaction conditions and conversions used in the current design. 
Table 13. Reaction Conditions and Key Parameters for Lignin BCD

\begin{tabular}{lc}
\hline Temperature & $120^{\circ} \mathrm{C}$ \\
Pressure & $6.3 \mathrm{~atm}$ \\
NaOH loading (minimum required), wt \% & $5.1 \%(2 \%)$ \\
Residence time & $30 \mathrm{~min}$ \\
Total solubilization, wt \% solids & $36 \%$ \\
Deconstruction extents & \\
Carbohydrate deconstruction (cellulose, xylan, arabinan) & $48 \%$ \\
Lignin deconstruction & $53 \%$ \\
\hline
\end{tabular}

All bioconversion assumptions are also maintained consistent with those documented in the 2018 design report. This includes the use of a seed train reflecting three stages of sequentially larger reactor volumes from 0.3 to 3 to $100 \mathrm{~m}^{3}$, consuming only sugars in a ratio of $46 \%$ conversion to cell mass and $54 \%$ conversion to muconic acid (applied equally to glucose, xylose, and arabinose sugars). This also includes routing the remaining majority of the feed to production bioreactors utilizing $1,000-\mathrm{m}^{3}$ bubble column vessels with a pump-around loop circulated through a cooler, and compressed air delivered to satisfy required oxygen transfer rates matched up with fermentation production rates. The net metabolic stoichiometry and conversion of the muconic acid fermentation is a combination of theoretical maximum metabolic yields and maintenance/respiration reactions dependent on the substrate consumed. For the production reaction, Table 14 lists the biological reactions and conversion to product for the carbon sources in the feed stream. The fermentation is run in a fed-batch mode, with an assumed average working volume of $70 \%$. Temperature is controlled at $32^{\circ} \mathrm{C}$ and operates at a mild positive pressure of $1.34 \mathrm{~atm}$, which assists in maintaining the axenic process. Overall, to completely convert the feed stream requires 18 and 19 bubble columns in the integrated and dedicated plants, respectively. The current design implements $\mathrm{pH}$ control to neutralize the muconic acid produced during the fermentation (as needed in excess of the caustic in solution) administered in the pumparound loop after cooling the broth. The overall fermentation is targeted to occur at a net productivity of $1 \mathrm{~g}$ muconic acid/L/h across all consumed substrates. Table 14 also summarizes the major reactor specifications for the production system.

Table 14. Lignin Fermentation Conditions and Conversion Targets

\begin{tabular}{|c|c|}
\hline Seed train volume (stage $1,2,3$ ) & $0.3,3,100 \mathrm{~m}^{3}$ \\
\hline Number of seed trains & 3 \\
\hline Production reactor size & $1,000 \mathrm{~m}^{3}$ \\
\hline Production reactor temperature & $32^{\circ} \mathrm{C}$ \\
\hline Muconic acid productivity & $1.0 \mathrm{~g} / \mathrm{L}-\mathrm{h}$ \\
\hline Net muconic acid titer & $68.5 \mathrm{~g} / \mathrm{L}$ \\
\hline Conversion: Glucose + $1.18 \mathrm{O} 2+0.28 \mathrm{NH}_{3} \rightarrow 4.8 P$. putida $+1.2 \mathrm{CO}_{2}+1.98 \mathrm{H} 2 \mathrm{O}$ & $46 \%$ \\
\hline Conversion: Glucose $+1.94 \mathrm{O}_{2} \rightarrow 0.74$ Muconic $+1.57 \mathrm{CO}_{2}+3.78 \mathrm{H} 2 \mathrm{O}$ & $54 \%$ \\
\hline Conversion: Xylose $+0.98 \mathrm{O} 2+0.23 \mathrm{NH}_{3} \rightarrow 4$ P. putida $+1 \mathrm{CO}_{2}+1.64 \mathrm{H} 2 \mathrm{O}$ & $46 \%$ \\
\hline Conversion: Xylose + $1.57 \mathrm{O}_{2} \rightarrow 0.62$ Muconic + $1.26 \mathrm{CO}_{2}+3.13 \mathrm{H} 2 \mathrm{O}$ & $54 \%$ \\
\hline Conversion: Arabinose $+0.98 \mathrm{O} 2+0.23 \mathrm{NH}_{3} \rightarrow 4$ P. putida $+1 \mathrm{CO}_{2}+1.64 \mathrm{H} 2 \mathrm{O}$ & $46 \%$ \\
\hline Conversion: Arabinose $+1.57 \mathrm{O}_{2} \rightarrow 0.62$ Muconic $+1.26 \mathrm{CO}_{2}+3.13 \mathrm{H} 2 \mathrm{O}$ & $54 \%$ \\
\hline Conversion: Sucrose $+2.35 \mathrm{O} 2+0.56 \mathrm{NH}_{3} \rightarrow 9.6 P$. putida $+2.4 \mathrm{CO}_{2}+2.96 \mathrm{H} 2 \mathrm{O}$ & $46 \%$ \\
\hline Conversion: Sucrose $+3.8731 \mathrm{O}_{2} \rightarrow 1.48$ Muconic $+3.13 \mathrm{CO}_{2}+6.57 \mathrm{H} 2 \mathrm{O}$ & $54 \%$ \\
\hline Conversion: Acetate $+.39 \mathrm{O} 2+0.093 \mathrm{NH}_{3} \rightarrow 1.6$ P. putida $+0.4 \mathrm{CO}_{2}+0.66 \mathrm{H} 2 \mathrm{O}$ & $100 \%$ \\
\hline Conversion: Extractives $+0.68 \mathrm{O} 2+0.28 \mathrm{NH}_{3} \rightarrow 4.8 P$. putida $+1.2 \mathrm{CO}_{2}+1.98 \mathrm{H} 2 \mathrm{O}$ & $46 \%$ \\
\hline Conversion: Extractives + $1.44 \mathrm{O}_{2} \rightarrow 0.74$ Muconic + $1.57 \mathrm{CO}_{2}+3.78 \mathrm{H} 2 \mathrm{O}$ & $54 \%$ \\
\hline Conversion: Lignin $+3 \mathrm{O}_{2} \rightarrow 1$ Muconic $+2 \mathrm{CO}_{2}+1 \mathrm{H}_{2} \mathrm{O}$ & $100 \%$ \\
\hline
\end{tabular}


After the fermentation, the collected broth is sent through an ultrafilter to remove debris and cell mass. The remaining solids are sent to wastewater treatment and eventually burned in the high-solids boiler. The recovered liquid is carbon filtered to remove coloring compounds and then proceeds to the muconic acid recovery system. The muconic acid is acidified and recovered via low-temperature crystallization in the acid form [14]. The crystallization occurs at a temperature of $15^{\circ} \mathrm{C}$ and a pH of 2 , recovering $98.8 \%$ of the product. The entrained liquid in the crystal is removed via a fluidized-bed drier, and then redissolved into an ethanol solvent. The ethanol:muconic acid ratio is set at 4, constrained to remain above the solubility limit of muconic acid in ethanol. Table 15 lists the key crystallizer metrics. Finally, muconic acid is hydrogenated to adipic acid in a three-stage packed-bed reactor operating at $40 \mathrm{~atm}$. Hydrogen is fed in excess at a molar ratio of $2.6 \mathrm{mols}_{2}$ :mol muconic acid to ensure complete hydrogenation. The reactor is operated over a $2 \%$ ruthenium on carbon catalyst at a mild temperature of $78^{\circ} \mathrm{C}$ to avoid cracking of the facile double bond backbone, as well as over hydrogenation of the acid end groups critical to the final polymer properties. After hydrogenation, the liquid proceeds to a flash evaporator, which concentrates the adipic acid to a ratio of 2.5 ethanol:adipic by mass at elevated temperatures. The concentrated adipic acid product stream is crystallized by lowering the temperature to $15^{\circ} \mathrm{C}[15,16] ; 73.4 \%$ of the adipic acid is removed per pass as crystals via centrifugation, and the mother liquor with the remaining uncrystallized adipic acid and ethanol is recycled back to the evaporation cycle until extinction. The recovered crystal product is sent to a drier to remove entrained ethanol, then stored on-site. Table 15 also summarizes the key design parameters for the hydrogenation reactor and adipic acid crystallizer.

Table 15. Muconic Acid Crystallizer Metrics

\begin{tabular}{lc}
\hline Muconic acid crystallizer target $\mathrm{pH}$ & 2 \\
Muconic acid crystallizer temperature & $15^{\circ} \mathrm{C}$ \\
Muconic acid crystallization recovery & $98.8 \%$ \\
Hydrogenation ethanol:muconic mass ratio & $4: 1$ \\
Hydrogenation temperature & $78^{\circ} \mathrm{C}$ \\
Hydrogenation pressure & $40 \mathrm{~atm}$ \\
Hydrogenation $\mathrm{H}_{2}$ :muconic molar ratio & 2.6 \\
Hydrogenation conversion & $100 \%$ \\
Hydrogenation catalyst & $2 \% \mathrm{Rh} / \mathrm{C}$ \\
Hydrogenation WHSV & $5 \mathrm{~h}^{-1}$ \\
Adipic acid crystallizer ethanol:adipic ratio & 2.5 \\
Adipic acid crystallizer temperature & $15^{\circ} \mathrm{C}$ \\
Adipic acid crystallization recovery (per-pass) & $73.4 \%$ \\
\hline
\end{tabular}

As documented in the 2018 design report, The BCD operation is costed based on a $127-\mathrm{m}^{3}$ pulping reactor vertical pressure vessel with a design similar to the pre-steaming section of the dilute acid pretreatment reactor [3]. All fermentation units are constructed of 304 or 316 stainless steel. The initial two seed fermentors are costed from prior seed tanks based on vendor quotations. The third seed unit and production unit are bubble column reactor units with a length-to-diameter ratio of 6 , estimated through a combination of industry quotations and ACCE cost modeling. Fermentation compressors were sized based on the required air flow rate for meeting the oxygen uptake rate demands, with a pressure increase determined by the reactor dimensions and hydraulic pressure at the bottom of the vessel. Ultrafiltration and carbon filtration units were estimated based on guidance from an engineering consultancy with Nexant and designed as a counter-current diafiltration package unit including feed pumps and controls. The unit is sized for a base membrane area of 53,820 $\mathrm{ft}^{2}$ and 
includes an operating cost for membrane replacement. The crystallizer, centrifuge, and crystal drier unit capital costs were scaled from estimates provided by Nexant. The adipic acid hydrogenation reactor was quoted as a low-pressure fixed-bed hydrodeoxygenation unit based on a prior engineering subcontract, adjusted for lower operating pressure relative to the original quotation. The adipic acid concentrator was designed as an initial mixing/feed tank, followed by a heat exchanger and flash evaporation tank constructed of SS316 for additional corrosion resistance. Adipic acid crystallizers, centrifuges, and dryers assumed similar designs as the muconic acid unit but scaled to the proper product stream.

\subsection{Area 800: Combustor, Boiler, and Turbogenerator}

Again, all assumptions pertaining to Area 800 remain consistent with the 2018 design report. In brief, the purpose of the combined heat and power subsystem is to burn residual byproduct streams to produce steam and electricity. Combustible byproducts include unconverted lignin and carbohydrates from the feedstock, cell mass from fermentation and WWT, and off-gas streams from catalytic upgrading operations. Combustion of these byproduct streams generates steam to drive the upgrading and separation operations, and partially offsets the plant's electric power demand. The fuel streams are fed to a bubbling fluidized-bed combustor boiler capable of handling the wet solids. A fan moves air into the combustion chamber. Treated water enters the heat exchanger circuit in the combustor and is boiled and superheated to high-pressure steam at $900 \mathrm{psig}$. A multistage turbine and generator are used to generate electricity. Steam is extracted from the turbine at two different conditions for use in the process. In the final stage of the turbine, the remaining steam is taken down to a vacuum and condensed with cooling water for maximum energy conversion. The condensate is returned to the boiler feed water system along with condensate from the various process heat exchangers. The steam turbine turns a generator that produces power for all use in the plant. The balance of required power is purchased from the grid (see Area 900). $\mathrm{NO}_{\mathrm{x}}$ emissions are mitigated with ammonia injection in a selective non-catalytic reduction system, and $\mathrm{SO}_{\mathrm{x}}$ emissions are mitigated with flue-gas desulfurization.

Whereas the 2018 design case required some natural gas (to provide supplemental heating demands in the BDO pathway and to drive a hot oil system for high-temperature utility heating in the acids pathway), the present case requires substantially more natural gas co-fired in the boiler to satisfy increased heat demands incurred in Areas 500 and 550. These are driven by large temperature swings between the key unit operations in Area 500 while processing large volume throughputs inclusive of water and dioxane solvent (as well as subsequent solvent distillation recovery). Likewise, high heat demands are incurred in Area 550 for vaporizing the aqueous BDO stream containing roughly $90 \%$ water, for subsequent catalytic conversion to MEK in the integrated biorefinery scenario.

The cost basis for the Area 800 equipment remains the same as described in the prior NREL reports, reflecting cost estimates furnished from vendor quotations for both the boiler and turbine system, as well as for most other minor equipment. The boiler capital cost includes the boiler feed water preheater, flue gas desulfurization spray dryer, and baghouse for collection of ash and particulates from the flue gas. For the baghouse, bag replacement appears as a periodic charge in the cash flow worksheet. 


\subsection{Area 900: Utilities}

Area 900 tracks all plant utilities except steam, which is provided by Area 800, including electric power, cooling water, chilled water, plant and instrument air, process water, and the clean-in-place system. The process water manifold in Area 900 mixes fresh water with treated wastewater and condensate from the sugar evaporation system (assumed suitable for all plant users) and provides this water at a constant pressure to the facility. The clean-in-place system provides hot cleaning and sterilization chemicals to hydrolysis, bioconversion, and the enzyme production section. Consistent with prior designs, the cooling water system is designed for a $28^{\circ} \mathrm{C}$ supply temperature with a $9^{\circ} \mathrm{C}$ temperature rise in coolers throughout the facility. This is an assumed average rise; the actual cooling water rises across each exchanger are not explicitly modeled in Aspen. The cooling water demands are summarized in Figure 10.

Similar to the trends in the 2018 design report, heat balances are considerably different for this pathway relative to prior NREL biochemical models, with the present cases resulting in a net heat deficit requiring supplemental natural gas. Accordingly, after extracting steam from intermediate turbine stages to satisfy process steam/heat demands, a minimal amount of steam remains passing through the final turbine stage and subsequent condenser (which historically had been the largest cooling demand and thus source of cooling tower losses/makeup water requirements in prior NREL models). In the present models, the core conversion operations in Areas 500 and 550 constitute the majority of the facility cooling requirements, representing over $50 \%$ of total cooling water demands in either biorefinery scenario. In the dedicated scenario, dioxane recovery constitutes the single largest cooling requirement (28\%), followed by other Area 500 operations $(26 \%)$, whereas in the integrated scenario, coolers used in the added MEK production train represent the largest cooling duty (24\%), followed again by dioxane recovery (17\%) and other Area 500 coolers (15\%). The chiller condenser also represents a significant fraction of cooling demands, at $24 \%$ in both scenarios. The compressor electricity demand for the chiller was estimated at $0.56 \mathrm{~kW} /$ ton of refrigeration and the cooling water demand for the chiller system was assumed to be equal to the heat removed in the chilled-water loop.
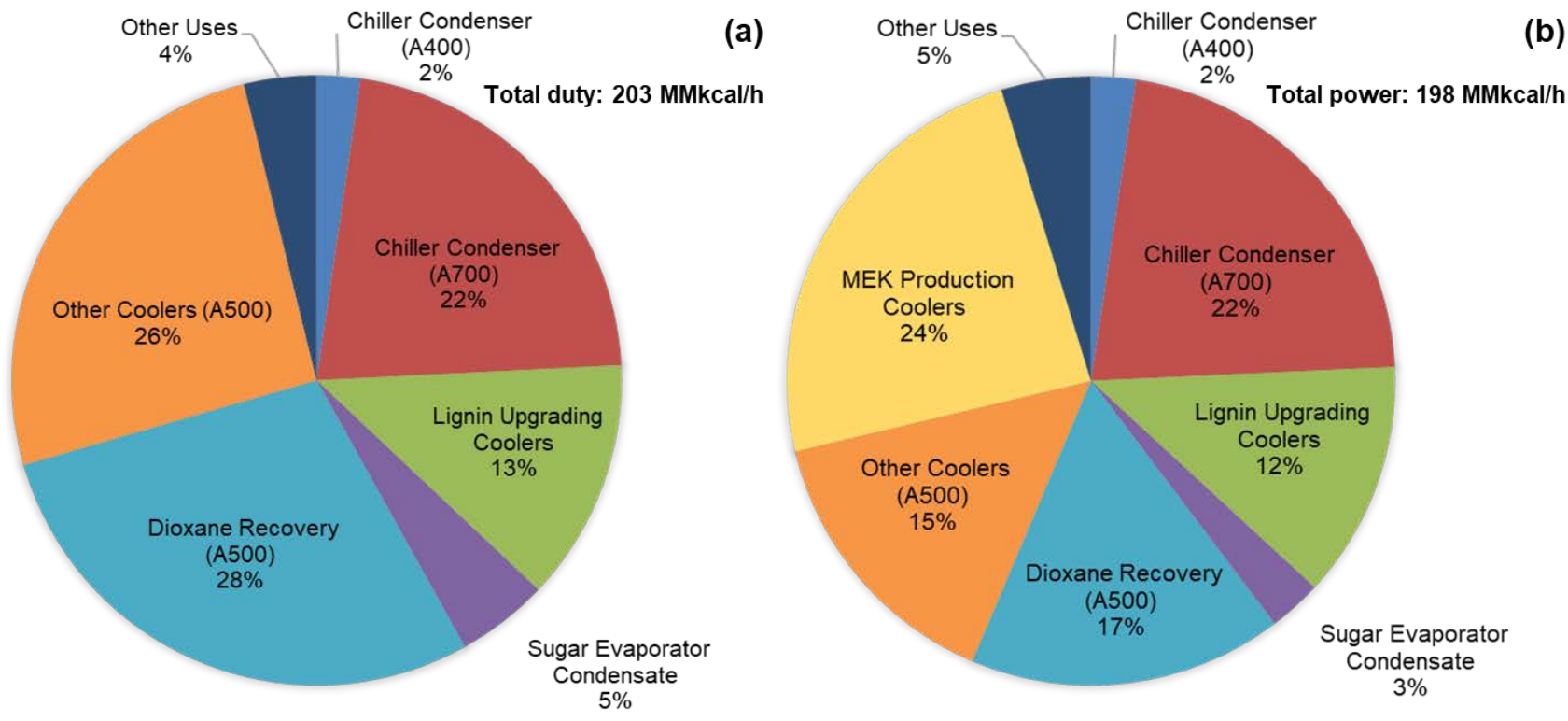

Figure 10. Cooling water heat duty distribution between major users in the (a) dedicated case and (b) integrated case 
The electricity generated in Area 800 is used to partially offset the plant power demand throughout the facility to power pumps, agitators, compressors, etc. (68.7 MW total power required for the dedicated biorefinery scenario and 61.2 MW for the integrated scenario), but there is still a considerable power deficit on the order of roughly 35-52 MW that must be imported from the grid after considering the power generated on-site. The distribution of total plant power utilization among all areas is shown in Figure 11. Note that the cost of the power required by Area 100 is already assumed to be included in the feedstock cost and is subtracted from the plant's net electricity import. This is reflected in the economics by an operating cost credit equal to this amount of electricity.

Consistent with the 2018 design case pathways, for both biorefinery scenarios in the present analysis, Area 200 constitutes the single largest power demand, primarily due to the switch to DMR pretreatment in this design, with high power demands to drive the mechanical refining equipment. Area 700 also reflects a sizeable share of the facility power demands associated with compressors for aerobic fermentation and downstream coproduct recovery operations. The new Area 500 operations do not exhibit disproportionately high power requirements, as they are driven primarily by heat demands for elevated temperature catalysis operations.
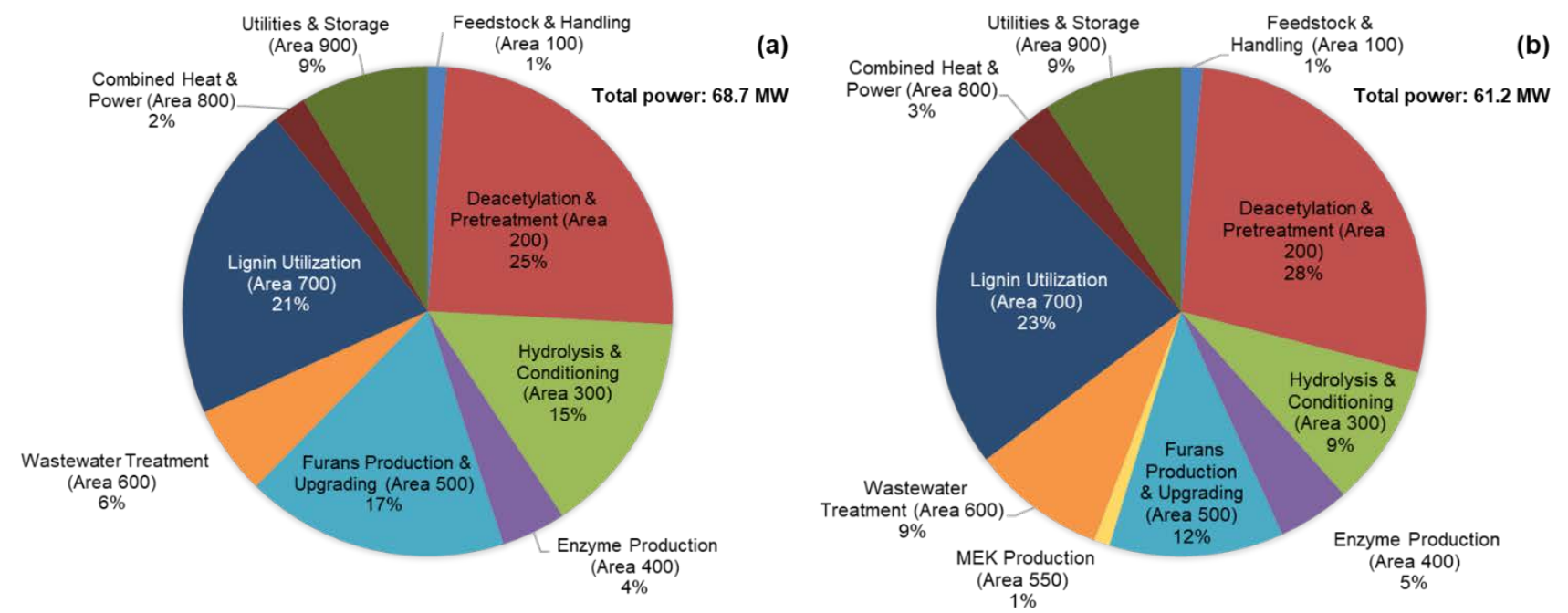

Figure 11. Distribution of plant electricity utilization by process area for the (a) dedicated case and (b) integrated case

All cost estimates for the utility equipment in Area 900 were maintained consistent with the basis values used in prior NREL reports. To summarize, the cooling tower was based on a cost estimate from a vendor for a fiberglass cooling tower capable of handling 44,000 gal $/ \mathrm{min}$; this cost is scaled to the respective cooling water throughputs estimated here. Most costs for the remaining operations in this section were furnished from an engineering subcontractor.

\section{Process Economics}

This section summarizes the key inputs and results for the modeled biorefinery scenarios, with more details available in previous reports [2]. The TCI is first computed from the total equipment cost. Next, variable and fixed operating costs are determined. With these costs, we use a discounted cash flow analysis to determine the minimum fuel selling price required to obtain a zero net present value with a fixed internal rate of return. The analysis does not consider any policy factors (e.g., subsidies and carbon credits) or early pioneer plant economics, but instead focuses strictly on the economic 
implications of the technical parameters modeled here as may factor into $n^{\text {th }}$-plant technology maturity levels.

The cost-year of 2016 was maintained for this analysis as consistent with the 2018 design report. As presented in prior design cases and other reports $[2,17]$, capital costs were adjusted using the Plant Cost Index from Chemical Engineering Magazine [18] to a common basis year of 2016. Similarly, for chemical/material costs, we used the Producer Price Index for chemical manufacturing published by the U.S. Bureau of Labor Statistics [19]. Employee salaries were maintained from prior basis values and were scaled to 2016 using the labor indices provided by the U.S. Bureau of Labor Statistics [19]. The general formula for cost-year dollar back-casting is:

$$
2016 \text { Cost }=(\text { Base Cost })\left(\frac{2016 \text { Cost Index }}{\text { Base Year Index }}\right)
$$

\subsection{Total Capital Investment}

Section 3 of this report describes the details of the conceptual process designs and how the purchased cost of the equipment was determined. The next step is to determine the installed cost of that equipment. In keeping with standard NREL TEA methodology, a factored approach in which multipliers are applied to the purchased equipment cost is maintained for estimating installed costs. In summary, each type of equipment utilizes a different installation factor to scale the given direct equipment purchased cost to a final installed cost. A complete list of the equipment is provided in Appendix A, along with equipment purchased and installed costs. The purchased cost for a given component reflects a baseline equipment size. As changes are made to the process, the equipment size required may be different than what was originally designed and costed. Instead of re-costing in detail, a standard exponential scaling expression was used:

$$
\text { New Cost }=(\text { Base Cost })\left(\frac{\text { New Size }}{\text { Base Size }}\right)^{n}
$$

In this equation, the scaling exponent $n$ varies depending on the type of equipment to reflect economyof-scale dependencies. The basis for scaling is typically some characteristic of the equipment related to production capacity, such as flow or heat duty. Some equipment does not follow such a scaling-factor approach, namely when the capacity for a given operation is exceeded and requires multiple units in parallel, thus losing economy-of-scale benefits that are captured in this exponential expression.

Once the total equipment cost has been determined in the year of interest, several other direct and indirect costs were added to determine the TCI (detailed in Table 16). Site development and warehouse costs, along with additional piping, are based on the inside-battery-limits (ISBL) equipment costs (Areas 200, 300, 400, 500, 550, and 700 in this design) and are considered part of the total direct cost (TDC). Beyond the ISBL operations, the other process areas are considered outside battery limits, including Areas 100 (rolled up into feedstock costs), 600, 800, and 900. Project contingency, field expenses, home office engineering and construction activities, and other costs related to construction are computed relative to the TDC and give the fixed capital investment (FCI) when summed. The categories and values for these additional cost escalation factors were maintained consistently with prior NREL design reports, and the reader is referred there for further details [2, 3]. 
Table 16. Project Cost Worksheet Including TDC and TCI (2016\$)

\begin{tabular}{|c|c|c|c|c|}
\hline \multirow[b]{2}{*}{ Process Area } & \multicolumn{2}{|c|}{ Dedicated Case } & \multicolumn{2}{|c|}{ Integrated Case } \\
\hline & $\begin{array}{l}\text { Purchased } \\
\text { Cost }\end{array}$ & Installed Cost & $\begin{array}{c}\text { Purchased } \\
\text { Cost }\end{array}$ & $\begin{array}{c}\text { Installed } \\
\text { Cost }\end{array}$ \\
\hline Area 100: Feedstock Storage and Handling ${ }^{a}$ & \multicolumn{2}{|c|}{ Included in feedstock cost } & \multicolumn{2}{|c|}{ Included in feedstock cost } \\
\hline Area 200: Pretreatment & $\$ 35,800,000$ & $\$ 48,700,000$ & $\$ 35,800,000$ & $\$ 48,700,000$ \\
\hline Area 300: Enzymatic Hydrolysis \& Hydrolysate Conditioning & $\$ 34,000,000$ & $\$ 59,800,000$ & $\$ 24,000,000$ & $\$ 42,100,000$ \\
\hline Area 400: Enzyme Production & $\$ 6,700,000$ & $\$ 11,500,000$ & $\$ 6,700,000$ & $\$ 11,500,000$ \\
\hline Area 500: Furans Production and Upgrading & $\$ 26,700,000$ & $\$ 43,000,000$ & $\$ 18,600,000$ & $\$ 29,600,000$ \\
\hline Area 550: MEK Production (Integrated case) & - & - & $\$ 12,700,000$ & $\$ 25,100,000$ \\
\hline Area 600: Wastewater Treatment ${ }^{\mathrm{b}}$ & $\$ 16,500,000$ & $\$ 31,300,000$ & $\$ 18,800,000$ & $\$ 35,700,000$ \\
\hline Area 700: Lignin Upgrading & $\$ 66,100,000$ & $\$ 140,000,000$ & $\$ 63,700,000$ & $\$ 134,700,000$ \\
\hline Area 800: Combustor, Boiler, and Turbogenerator & $\$ 33,200,000$ & $\$ 60,100,000$ & $\$ 38,900,000$ & $\$ 70,400,000$ \\
\hline Area 900: Utilities & $\$ 11,500,000$ & $\$ 20,000,000$ & $\$ 10,400,000$ & $\$ 18,000,000$ \\
\hline Totals (Excl. Area 100) & $\$ 230,600,000$ & $\$ 414,300,000$ & $\$ 229,600,000$ & $\$ 415,800,000$ \\
\hline Warehouse & $4.0 \%$ of ISBL & $\$ 12,100,000$ & & $\$ 11,700,000$ \\
\hline Site development & $9.0 \%$ of ISBL & $\$ 27,300,000$ & & $\$ 26,200,000$ \\
\hline Additional piping & $4.5 \%$ of ISBL & $\$ 13,600,000$ & & $\$ 13,100,000$ \\
\hline Total Direct Costs & & $\$ 467,300,000$ & & $\$ 466,900,000$ \\
\hline Proratable expenses & $10.0 \%$ of TDC & $\$ 46,700,000$ & & $\$ 46,700,000$ \\
\hline Field expenses & $10.0 \%$ of TDC & $\$ 46,700,000$ & & $\$ 46,700,000$ \\
\hline Home office and construction fee & $20.0 \%$ of TDC & $\$ 93,500,000$ & & $\$ 93,400,000$ \\
\hline Project contingency & $10.0 \%$ of TDC & $\$ 46,700,000$ & & $\$ 46,700,000$ \\
\hline Other costs (startup, permits, etc.) & $10.0 \%$ of TDC & $\$ 46,700,000$ & & $\$ 46,700,000$ \\
\hline Total Indirect Costs & & $\$ 280,400,000$ & & $\$ 280,100,000$ \\
\hline Fixed Capital Investment & & $\$ 747,600,000$ & & $\$ 747,000,000$ \\
\hline Land & & $\$ 1,800,000$ & & $\$ 1,800,000$ \\
\hline Working capital & $5.0 \%$ of $\mathrm{FCl}$ & $\$ 37,400,000$ & & $\$ 37,400,000$ \\
\hline Total Capital Investment & & $\$ 786,900,000$ & & $\$ 786,200,000$ \\
\hline Lang factor (TCl/purchased equip. cost) & & 3.6 & & 3.7 \\
\hline $\mathrm{TCl}$ per annual gallon gasoline equivalent & & $\$ 10.02 / G G E$ & & $\$ 17.75 / G G E$ \\
\hline
\end{tabular}

${ }^{a}$ Feedstock handling not included in this calculation.

${ }^{\mathrm{b}}$ Area 600 not included in Lang factor.

\subsection{Variable Operating Costs}

Variable operating costs, which include raw materials, waste handling charges, and byproduct credits, are incurred only when the process is operating. Quantities of raw materials used and wastes produced were determined using the Aspen material balance. Table 17 documents the costs and sources of chemicals used in the process and Table 18 summarizes the variable costs on a per-year and per-GGE basis. All costs for materials used in NREL's 2018 design report were maintained consistently here, including those that had been updated reflecting new cost information available at that time-i.e., ammonia, sulfuric acid, glucose (concentrated glucose syrup), diammonium phosphate, and sodium hydroxide, as well as sodium sulfate salt sold as an additional coproduct [1]. As discussed in that report, the sodium sulfate salt must be sold to offset elevated expenses incurred for substantial use of sodium hydroxide throughout the facility (representing an MFSP contribution of roughly $\$ 0.50-$ $\$ 0.90 / \mathrm{GGE}$ in the present biorefinery scenarios). Both pathways require a net power import after considering the amount of power generated through the combined heat and power system, costed consistently with prior design cases with grid imports at $6.8 \phi / \mathrm{kWh}$. For this assessment, natural gas 
costs were reduced from $\$ 5$ to $\$ 3.50 / \mathrm{MM} \mathrm{BTU}$, reflecting an average of natural gas prices over more recent years [20]. Adipic acid is coproduced in the lignin train at a product purity over $99.7 \mathrm{wt} \%$, with a sale price set at $\$ 1,710 /$ short ton $(\$ 0.86 / \mathrm{lb}$ ) in $2016 \$$, reflective of a 15 -year average price for this product. Further discussion on historical price fluctuations and rationale for the selection of this value is provided in the 2018 design report. Sensitivity on overall biorefinery MFSP to the adipic acid coproduct value is considered in Sections 5.2.1 and 5.2.2.

Costs for additional/new chemicals as required for this pathway are also reflected in Table 17. Key among them is the assumed cost for the MEK co-reactant applied in the dedicated biorefinery scenario when purchasing this component externally. Chemical-grade MEK derived from conventional chemistries may be purchased at a cost of roughly $\$ 0.77 / 1 \mathrm{~b}$ (based on an average of recent market prices); however, such a cost would cause steep penalties in the resultant MFSP (reflected in the sensitivity analysis described later) and would also likely incur substantial penalties in the life cycle assessment for this pathway, given that conventional MEK is synthesized from petrochemical routes via butene. Accordingly, to achieve viability for this pathway, MEK or another ketone purchased externally should be bio-derived (to improve the life cycle assessment profile) and need not be available at chemical-grade purities (to reduce costs). In the present analysis, the dedicated biorefinery scenario assumes a "transfer price" of $\$ 0.30 / \mathrm{lb}$ MEK as an approximate calculation for the minimum selling price of bio-MEK produced from a separate stand-alone 2,000-tonne/day biorefinery configured for exclusive production of this component-i.e., for a dedicated facility mirroring Area 550 of this report inclusive of a similar lignin coproduct train, based on discussions with PNNL collaborators coordinating the research work for the BDO-to-MEK catalysis pathway [13]. Accordingly, the primary difference between the dedicated and integrated biorefinery scenarios is ultimately the economy of scale for a single 2,000-tonne/day biorefinery simultaneously producing both products or two separate biorefineries of that scale, each producing their respective intermediates (furans and MEK); although in the latter case, more MEK would be produced than needed for reaction with furans and could proceed on (e.g., to final fuel upgrading through subsequent catalysis steps). 
Table 17. Chemical Costs and Sources

\begin{tabular}{|c|c|c|}
\hline Component & Cost (2016\$) & Source \\
\hline Biomass delivered to reactor throat & $\$ 0.0285 / \mathrm{lb}$ & $\begin{array}{l}\text { Idaho National Laboratory inputs, } \$ 71.26 / \text { dry ton @ } \\
20 \% \text { moisture }\end{array}$ \\
\hline Sulfuric acid, 93\% & $\$ 0.0430 / \mathrm{lb}$ & Industry database, 5-year average \\
\hline Ammonia & $\$ 0.1900 / \mathrm{lb}$ & Industry database, 5-year average \\
\hline Sodium hydroxide & $\$ 0.2384 / \mathrm{lb}$ & Nexant (indexed from $2011 \$$ basis) \\
\hline Ultrafilter replacement & $0.0297 \$ / \$$ cost & Nexant (annual cost per \$ membrane CAPEX) \\
\hline Corn steep liquor & $\$ 0.0339 / \mathrm{lb}$ & Corn products via Harris Group \\
\hline Diammonium phosphate & $\$ 0.1645 / \mathrm{lb}$ & Industry database, 5-year average \\
\hline Corn oil (antifoam) & $\$ 0.6439 / \mathrm{lb}$ & Industry database \\
\hline Glucose & $\$ 0.3670 / \mathrm{lb}$ & $\begin{array}{l}\text { U.S. Department of Agriculture Economic } \\
\text { Research Service, } 5 \text {-year average [21] }\end{array}$ \\
\hline $\mathrm{SO}_{2}$ & $\$ 0.1811 / \mathrm{lb}$ & Industry database \\
\hline Enzyme nutrients & $\$ 0.4896 / \mathrm{lb}$ & $\begin{array}{l}\text { Industry database (see } 2011 \text { design report for } \\
\text { details) }\end{array}$ \\
\hline Hydrogen & $\$ 0.7306 / \mathrm{lb}$ & $\begin{array}{l}\text { U.S. Department of Energy report, steam methane } \\
\text { reforming } \mathrm{H}_{2} @ \$ 4 / \mathrm{MM} \text { BTU natural gas [22] }\end{array}$ \\
\hline BDO upgrading catalyst a & $\$ 32.34 / \mathrm{lb}$ & NREL internal database \\
\hline Dioxane & $\$ 0.764 / \mathrm{lb}$ & Industry database, 5 -year average \\
\hline Aluminum chloride & $\$ 0.1682 / \mathrm{lb}$ & Industry database, 5 -year average \\
\hline MEK & $\$ 0.30 / \mathrm{lb}$ & Estimated transfer price for biobased MEK \\
\hline Hydrotreating catalyst & $\$ 105 / \mathrm{lb}$ & NREL internal database \\
\hline Polymer for WWT & $\$ 2.6282 / \mathrm{lb}$ & Brown and Caldwell 2012 WWT design [23] \\
\hline Ethanol & $\$ 0.3370 / \mathrm{lb}$ & Prior NREL analysis \\
\hline Natural gas & \$3.5/MM BTU & $\begin{array}{l}\text { Average } 2016 \text { values retrieved from the U.S. } \\
\text { Energy Information Administration [20] }\end{array}$ \\
\hline Lime & $\$ 0.1189 / \mathrm{lb}$ & Harris Group \\
\hline Boiler chemicals & $\$ 2.9772 / \mathrm{lb}$ & 2002 design report [7] \\
\hline Cooling tower chemicals & $\$ 1.7842 / \mathrm{lb}$ & 2002 design report [7] \\
\hline Fresh water & $\$ 0.0002 / \mathrm{lb}$ & Peters and Timmerhaus [24] \\
\hline Sodium sulfate salt coproduct value & $\$ 0.0706 / \mathrm{lb}$ & Nexant (indexed from $2011 \$$ basis) \\
\hline Adipic acid coproduct value & $\$ 0.8554 / \mathrm{lb}$ & Average price over a 15 -year cycle \\
\hline
\end{tabular}

a Price of catalyst assumed to be that of an H-ZSM-5 zeolite 
Table 18. Variable Operating Costs

\begin{tabular}{|c|c|c|c|c|c|c|c|}
\hline $\begin{array}{l}\text { Process } \\
\text { Area }\end{array}$ & Stream Description & $\begin{array}{l}\text { Dedic. } \\
\text { Usage } \\
(\mathrm{kg} / \mathrm{h})^{\mathrm{a}}\end{array}$ & $\begin{array}{l}\text { Integr. } \\
\text { Usage } \\
(\mathrm{kg} / \mathrm{h})^{\mathrm{a}}\end{array}$ & $\begin{array}{l}\text { Dedic. } \\
\text { MM\$/yr } \\
(2016 \$)\end{array}$ & $\begin{array}{l}\text { Integr. } \\
\text { MM\$/yr } \\
(2016 \$)\end{array}$ & $\begin{array}{l}\text { Dedic. } \\
\phi / G G E \\
(2016 \$)\end{array}$ & $\begin{array}{c}\text { Integr. } \\
\text { c/GGE } \\
(2016 \$)\end{array}$ \\
\hline \multicolumn{8}{|c|}{ Raw Materials } \\
\hline $\mathrm{N} / \mathrm{A}$ & Feedstock & 104,167 & 104,167 & 51.62 & 51.62 & 65.72 & 116.51 \\
\hline \multirow[t]{3}{*}{ A200 } & Sulfuric acid, 93\% & 0 & 0 & 0 & 0 & 0 & 0 \\
\hline & Caustic (as pure) & 5,833 & 5,833 & 24.17 & 24.17 & 30.78 & 54.57 \\
\hline & Ammonia & 0 & 0 & 0 & 0 & 0 & 0 \\
\hline A300 & Flocculant & 345 & 195 & 6.35 & 3.58 & 8.09 & 8.09 \\
\hline \multirow[t]{6}{*}{ A400 } & Glucose & 1,324 & 1,324 & 8.45 & 8.45 & 10.75 & 19.06 \\
\hline & Corn steep liquor & 90 & 90 & 0.05 & 0.05 & 0.07 & 0.12 \\
\hline & Corn oil & 7 & 7 & 0.08 & 0.08 & 0.10 & 0.18 \\
\hline & Ammonia & 63 & 63 & 0.21 & 0.21 & 0.26 & 0.47 \\
\hline & Host nutrients & 37 & 37 & 0.31 & 0.31 & 0.40 & 0.71 \\
\hline & Sulfur dioxide & 9 & 9 & 0.03 & 0.03 & 0.04 & 0.06 \\
\hline \multirow[t]{6}{*}{ A500 } & Dioxane & 209 & 120 & 2.77 & 1.59 & 3.53 & 3.58 \\
\hline & Aluminum chloride & 949 & 535 & 2.77 & 1.56 & 3.53 & 3.53 \\
\hline & Caustic (as pure) & 1,220 & 688 & 5.05 & 2.85 & 6.44 & 6.44 \\
\hline & Methyl ethyl ketone & 9,301 & - & 48.51 & - & 61.76 & - \\
\hline & Hydrogen & 3,522 & 1,799 & 44.73 & 22.84 & 56.95 & 51.56 \\
\hline & Hydrotreating catalyst ${ }^{b}$ & 1.2 & 0.7 & 0.36 & 0.20 & 0.46 & 0.46 \\
\hline \multirow[t]{3}{*}{ A550 } & Corn steep liquor & - & 265 & - & 0.16 & - & 0.35 \\
\hline & Diammonium phosphate & - & 32 & - & 0.09 & - & 0.21 \\
\hline & BDO upgrading catalyst ${ }^{b}$ & - & 1.3 & - & 0.60 & - & 1.57 \\
\hline \multirow[t]{2}{*}{ A600 } & Ammonia & 0 & 55 & 0 & 0.18 & 0 & 0.41 \\
\hline & Polymer & 0.4 & 0.9 & 0.02 & 0.04 & 0.02 & 0.10 \\
\hline \multirow[t]{9}{*}{ A700 } & Caustic (as pure) & 3,218 & 2,972 & 13.34 & 12.32 & 16.98 & 27.80 \\
\hline & Ammonia & 95 & 91 & 0.31 & 0.30 & 0.40 & 0.68 \\
\hline & Diammonium phosphate & 616 & 589 & 1.76 & 1.69 & 2.24 & 3.80 \\
\hline & Corn steep liquor & 144 & 126 & 0.08 & 0.07 & 0.11 & 0.17 \\
\hline & Sulfuric acid, $93 \%$ & 11,560 & 11,241 & 8.64 & 8.40 & 11.00 & 18.97 \\
\hline & Ultrafilter replacement & Cost & Cost & 0.14 & 0.14 & 0.17 & 0.31 \\
\hline & Ethanol & 39 & 38 & 0.23 & 0.22 & 0.29 & 0.51 \\
\hline & Hydrogen & 426 & 417 & 5.41 & 5.30 & 6.88 & 11.95 \\
\hline & Hydrotreating catalyst ${ }^{b}$ & 0.7 & 0.7 & 0.84 & 0.82 & 1.07 & 1.85 \\
\hline \multirow[t]{4}{*}{ A800 } & Boiler chemicals & 0.2 & 0.2 & 0.01 & 0.01 & 0.02 & 0.03 \\
\hline & $\begin{array}{l}\text { Flue gas desulfurization } \\
\text { lime }\left(\mathrm{SO}_{x} \text { control) }\right.\end{array}$ & 87 & 94 & 0.18 & 0.19 & 0.23 & 0.44 \\
\hline & Ammonia $\left(\mathrm{NO}_{x}\right.$ control) & 836 & 950 & 2.76 & 3.14 & 3.51 & 7.08 \\
\hline & Natural gas & 6,500 & 9,700 & 9.45 & 14.10 & 12.03 & 31.82 \\
\hline \multirow[t]{2}{*}{ A900 } & Cooling tower chemicals & 5 & 5 & 0.14 & 0.14 & 0.18 & 0.32 \\
\hline & Makeup water & 281,059 & 284,836 & 0.75 & 0.76 & 0.96 & 1.72 \\
\hline \multirow[t]{2}{*}{ Power } & Grid electricity (kW) & 51,271 & 34,829 & 17.62 & 18.73 & 22.43 & 42.27 \\
\hline & Subtotal & & & 257.14 & 184.94 & 327.40 & 417.70 \\
\hline \multicolumn{8}{|c|}{ Waste Disposal } \\
\hline \multirow[t]{2}{*}{ A800 } & Disposal of ash & 4,252 & 4,265 & 1.40 & 1.41 & 1.78 & 3.17 \\
\hline & Subtotal & & & 1.40 & 1.41 & 1.78 & 3.17 \\
\hline \multicolumn{8}{|c|}{ Coproducts and Credits } \\
\hline A600 & Sodium sulfate (98.5 wt \%) & 13,770 & 13,946 & 16.91 & 17.12 & 21.53 & 38.65 \\
\hline \multirow[t]{2}{*}{ A700 } & Adipic acid (99.7 wt \% pure) & 11,812 & 11,494 & 175.65 & 170.93 & 223.65 & 385.80 \\
\hline & Subtotal & & & 192.56 & 188.05 & 245.18 & 424.45 \\
\hline \multicolumn{4}{|c|}{ Total Variable Operating Costs } & 65.98 & -1.70 & 84.00 & -3.58 \\
\hline
\end{tabular}

a For reference, to convert to kg/GGE basis, fuel outputs are 9,962 and 5,619 GGE/h for dedicated and integrated cases, respectively.

${ }^{\mathrm{b}}$ Catalyst usage amortized to $\mathrm{kg} / \mathrm{h}$ basis for consistency with rest of table. 


\subsection{Fixed Operating Costs}

Fixed operating costs are generally incurred in full whether or not the plant is producing at full capacity. These costs include labor and various overhead items. The assumptions on fixed operating costs were maintained consistently with the 2018 design report, which in turn were based in large part on NREL's 2002 ethanol design report [7] and/or Peters and Timmerhaus [24]. Table 19 shows the recommended number of employees and associated salaries. The number of employees was estimated by considering the likely degree of automation for each area and adding a reasonable number of management and support employees. Because the model feedstock is predominately corn stover, salaries were estimated for rural regions of the U.S. Midwest. These estimates may vary depending on location. A $90 \%$ labor burden is applied to the salary total and covers items such as safety, general engineering, general plant maintenance, payroll overhead (including benefits), plant security, janitorial and similar services, phone, light, heat, and plant communications. The $90 \%$ estimate is the median of the general overhead range suggested in the 2008 Process Economics Program Yearbook produced by SRI Consulting (now IHS) [25]. Table 20 shows the full fixed operating costs associated with both biorefineries. Annual maintenance materials were estimated as 3\% of the installed ISBL capital cost and property insurance, and local property tax was estimated as $0.7 \%$ of the fixed capital investment, based on the 1994 Chem Systems report described in NREL's 2011 ethanol report [2]. These factors are all consistent with those used in prior design reports.

Table 19. Positions and Salaries (\$/yr) for Employees

\begin{tabular}{lccc}
\hline Position & 2016 Salary & \# Required & 2016 Cost \\
\hline Plant manager & $\$ 164,452$ & 1 & $\$ 164,452$ \\
Plant engineer & $\$ 78,310$ & 4 & $\$ 313,241$ \\
Maintenance supervisor & $\$ 63,767$ & 1 & $\$ 63,767$ \\
Maintenance technician & $\$ 44,749$ & 12 & $\$ 536,985$ \\
Lab manager & $\$ 62,648$ & 1 & $\$ 62,648$ \\
Lab tech & $\$ 44,749$ & 2 & $\$ 89,498$ \\
Lab tech - enzyme & $\$ 44,749$ & 2 & $\$ 89,498$ \\
Shift supervisor & $\$ 53,699$ & 4 & $\$ 214,794$ \\
Shift operators & $\$ 44,749$ & 24 & $\$ 1,073,970$ \\
Shift operators - enzyme & $\$ 44,749$ & 8 & $\$ 357,990$ \\
Yard employees & $\$ 31,324$ & 4 & $\$ 125,297$ \\
Clerks and secretaries & $\$ 40,274$ & 3 & $\$ 120,822$ \\
\hline Total salaries & & & $\$ 3,212,962$ \\
Labor burden (90\%) & & & $\$ 2,891,655$ \\
\hline
\end{tabular}

Table 20. Fixed Operating Costs

\begin{tabular}{|c|c|c|c|c|}
\hline Labor and Supervision & $\begin{array}{c}\text { Dedicated } \\
\mathrm{MM} \$ / \mathrm{yr}\end{array}$ & $\begin{array}{c}\text { Integrated } \\
\text { MM } \$ / y r\end{array}$ & $\begin{array}{c}\text { Dedicated } \\
\text { \&/GGE }\end{array}$ & $\begin{array}{c}\text { Integrated } \\
\text { \&/GGE }\end{array}$ \\
\hline Total salaries & 3.21 & 3.21 & 4.09 & 7.25 \\
\hline Labor burden $(90 \%)$ & 2.89 & 2.89 & 3.68 & 6.53 \\
\hline Other Overhead & $\begin{array}{c}\text { Dedicated } \\
\text { MM } \$ / y r\end{array}$ & $\begin{array}{c}\text { Integrated } \\
M M \$ / y r\end{array}$ & $\begin{array}{c}\text { Dedicated } \\
\phi / G G E\end{array}$ & $\begin{array}{c}\text { Integrated } \\
\phi / G G E\end{array}$ \\
\hline Maintenance ( $3.0 \%$ of ISBL) & 9.09 & 8.75 & 11.57 & 19.75 \\
\hline Property insurance $(0.7 \%$ of $\mathrm{FCl})$ & 5.23 & 5.23 & 6.66 & 11.80 \\
\hline Total Fixed Operating Costs & 14.32 & 20.08 & 26.1 & 45.33 \\
\hline
\end{tabular}




\subsection{Discounted Cash Flow Analysis and the Minimum Fuel Selling Price}

\subsubsection{Discount Rate, Equity Financing, and Other Financial Metrics}

Consistent with standard NREL TEA practices, the discount rate (which is also the internal rate of return in this analysis) was maintained at $10 \%$ and the plant lifetime at 30 years. The $10 \%$ rate is consistent with all platforms across the Bioenergy Technologies Office portfolio, and more context on its basis is discussed in prior reports [1, 2]. Also consistent with other recent TEA reports, it was assumed that the plant would be $40 \%$ equity financed. The terms of the loan were established at $8 \%$ interest for 10 years. The principal is taken out in stages over the 3 -year construction period. Interest on the loan is paid during this period, but principal is not paid back (this is another $n^{\text {th }}$-plant assumption, which says that this cash flow comes from the parent company until the plant starts up).

Again, the Internal Revenue Service Modified Accelerated Cost Recovery System (MACRS) basis for depreciation schedules is maintained in the present design, which uses a 7-year recovery period for the majority of the plant except for the steam plant equipment (Area 800), which uses a 20 -year recovery period. The updated corporate tax rate of $21 \%$ is also maintained, without further consideration for state taxes. Likewise, the current analysis maintains the assumption of 12 months for planning and engineering, followed by 24 months for facility construction, with a startup time of 6 months and working capital of 5\% relative to FCI (all reflecting $n^{\text {th }}$-plant assumptions).

\subsubsection{Base Case TEA Results}

Based on the TEA parameters summarized here, the resulting MFSP of total fuel products is \$2.54/GGE for the dedicated case and \$2.72/GGE for the integrated case (2016\$), representative of the hydrocarbon fuel product adjusted by heating values (calculated in the Aspen model) to gasoline equivalents. Such MFSP results are analogous to those reported in NREL's aforementioned design case [1] focused on biological conversion of sugars to fermentation intermediates with subsequent catalytic upgrading of those intermediates to hydrocarbon fuels, at $\$ 2.47-\$ 2.49 /$ GGE. This indicates that such a route is another viable alternative pathway to achieve similar fuel cost targets through purely catalytic upgrading of sugars in this case.

Table 21 summarizes the yields and conversion costs for the present designs. According to Cran's methodology [6], the expected accuracy of the overall TCI analysis is $\pm 25 \%$ (although some specific pieces of equipment carry a higher degree of uncertainty in underlying cost estimates, as previously identified). If we apply this uncertainty to the TCI, the impact on the cost of total fuel is $\pm \$ 0.33 / \mathrm{GGE}$ and $\pm \$ 0.58 /$ GGE for the dedicated and integrated cases, respectively. The complete discounted cash flow summary worksheets are shown in Appendix B. The MFSP can be further broken down into the cost of each process area. Figure 12 and Figure 13 illustrate the contribution to the overall cost by process area and capital, operations, and fixed costs (the bar for feedstock plus handling reflects the single feedstock cost of $\$ 71.26 /$ dry U.S. tons delivered to pretreatment and has not been broken down). 
Table 21. Summary of Yields, Rates, and Conversion Costs for Both Biorefinery Configurations

\begin{tabular}{lcc}
\hline & Dedicated Biorefinery & Integrated Biorefinery \\
\hline Feedstock rate & 2,205 dry U.S. tons/day \\
Online time & $7,884 \mathrm{~h} / \mathrm{yr}$ (90\% online factor) \\
Total fuel yield & $108.4 \mathrm{GGE} /$ dry U.S. ton & $61.2 \mathrm{GGE} / \mathrm{dry}$ U.S. ton \\
Total fuel production rate & feedstock & $44.3 \mathrm{MM} \mathrm{GGE} / \mathrm{yr}$ \\
Adipic acid coproduct yield & $78.5 \mathrm{MM} \mathrm{GGE} / \mathrm{yr}$ & $276 \mathrm{lb} / \mathrm{dry} \mathrm{U.S.} \mathrm{ton} \mathrm{feedstock}$ \\
Adipic acid production rate & $284 \mathrm{Ib} / \mathrm{dry}$ U.S. ton feedstock & $200 \mathrm{MM} \mathrm{Ib/yr}$ \\
Total variable OPEX excluding coproducts & $205 \mathrm{MM} \mathrm{Ib/yr}$ & $\$ 187 \mathrm{MM} / \mathrm{yr}$ \\
Coproduct revenue & $\$ 269 \mathrm{MM} / \mathrm{yr}$ & $\$ 188 \mathrm{MM} / \mathrm{yr}$ \\
Total fixed OPEX & $\$ 193 \mathrm{MM} / \mathrm{yr}$ & $\$ 20 \mathrm{MM} / \mathrm{yr}$ \\
Total equipment cost & $\$ 20 \mathrm{MM} / \mathrm{yr}$ & $\$ 416 \mathrm{MM}$ \\
Total capital investment & $\$ 414 \mathrm{MM}$ & $\$ 786 \mathrm{MM}$ \\
TCl per annual gallon & $\$ 787 \mathrm{MM}$ & $\$ 17.75 / \mathrm{GGE}$ \\
Minimum Fuel Selling Price & $\$ 10.02 / \mathrm{GGE}$ & $\$ 2.72 / \mathrm{GGE}$ \\
Feedstock contribution & $\$ 2.54 / \mathrm{GGE}$ & $\$ 1.17 / \mathrm{GGE}$ \\
Fuel conversion contribution & $\$ 0.66 / \mathrm{GGE}$ & $\$ 3.71 / \mathrm{GGE}$ \\
Coproduct conversion contribution & $\$ 3.11 / \mathrm{GGE}$ & $-\$ 2.16 / \mathrm{GGE}$ \\
\hline
\end{tabular}

\begin{tabular}{|ll|}
\hline$\square$ Capital Recovery Charge & $\square$ Raw Materials, Catalyst, \& Waste \\
$\square$ Process Electricity & $\square$ Grid Electricity \\
\hline
\end{tabular}

Feedstock \& Handling: $65.7 \mathrm{C}$

Deacetylation \& Pretreatment: $58.9 \mathrm{C}$

Hydrolysis \& Conditioning: $36.6 \mathrm{C}$

Enzyme Production: 17.7c

Furans Production \& Upgrading: $155.8 \mathrm{C}$

Wastewater Treatment: $-7.3 \mathrm{C}$

Lignin Utilization: $-123.0 \mathrm{C}$

Boiler/Turbogenerator: $37.5 \mathrm{C}$

Utilities \& Storage: $12.0 \mathrm{C}$

Blank: $0.0 \mathrm{C}$

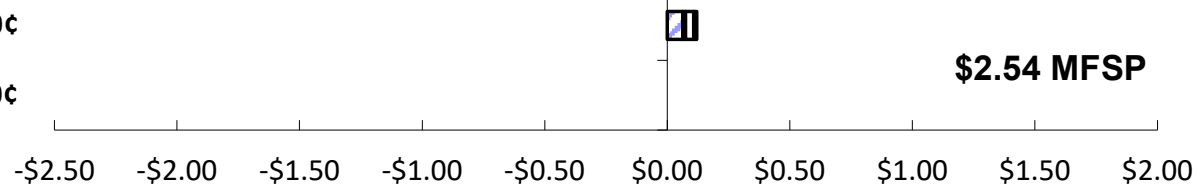

Figure 12. Dedicated case cost contribution details from each process area (per GGE total fuel) 


\begin{tabular}{|ll|}
\hline$\square$ Capital Recovery Charge & $\square$ Raw Materials, Catalyst, \& Waste \\
$\square$ Process Electricity & $\square$ Grid Electricity \\
\hline
\end{tabular}

Feedstock \& Handling: 116.5C

Deacetylation \& Pretreatment: $103.9 \mathrm{C}$

Hydrolysis \& Conditioning: $41.8 \mathrm{C}$

Enzyme Production: 31.2c

Furans Production \& Upgrading: $92.3 \mathrm{C}$

MEK Production: $19.4 \mathrm{C}$

Wastewater Treatment: $-9.0 \mathrm{C}$
Lignin Utilization: $-216.2 \mathrm{C}$

Boiler/Turbogenerator: $72.0 \mathrm{C}$

Utilities \& Storage: $19.7 \mathrm{C}$

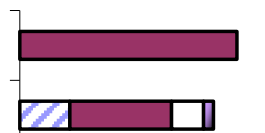

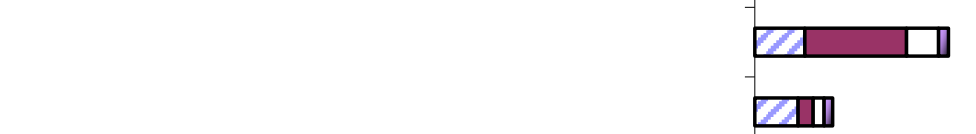

\begin{tabular}{llll}
\hline & \\
\hline &
\end{tabular}

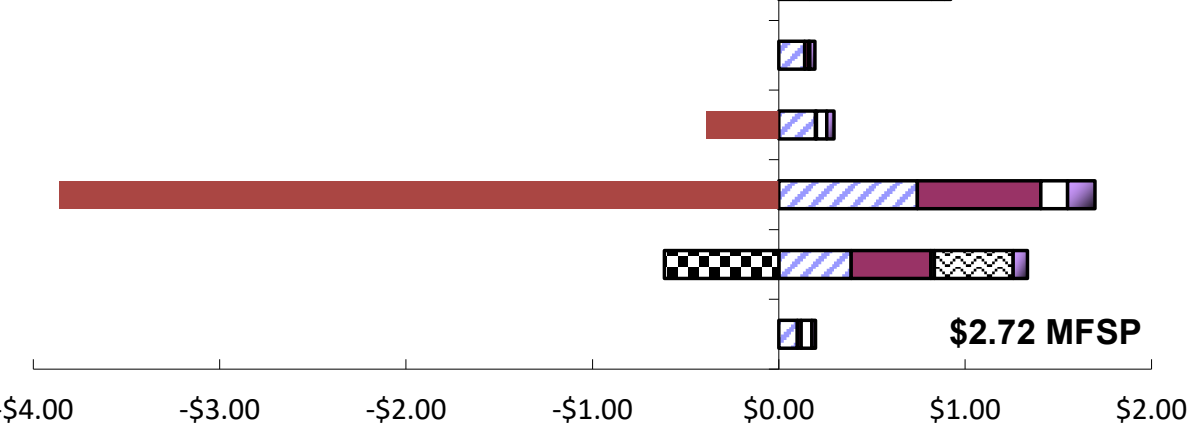

Figure 13. Integrated case cost contribution details from each process area (per GGE total fuel)

As shown in Table 21, Figure 12, and Figure 13, the MFSP estimates are seen to vary by approximately $\$ 0.18 / \mathrm{GGE}$ between the two biorefinery configurations. The dedicated biorefinery case assumes a purchase cost of $\$ 0.30 / \mathrm{lb}$ MEK, representing an estimated "transfer price" from a separate facility that is otherwise producing bio-MEK through the same processing steps as those modeled here but with the sugar conversion train focused exclusively on BDO-to-MEK production (mirroring Area 550 in the integrated case). Given this, this difference in MFSP is ultimately a reflection of economies of scale for a single 2,000-tonne/day biorefinery coproducing both the furan and MEK coreactants simultaneously versus two separate biorefineries of this scale each producing the respective intermediates. As such, although the dedicated biorefinery views the MEK as an externally sourced chemical to support its own operations, unless that MEK or an alternate ketone could be sourced from a non-fossil feedstock that was also not a terrestrial biomass crop (e.g., a waste feedstock that may be upgraded to such a ketone), the integrated case ultimately represents the fuel yields that can be achieved per ton of starting biomass (corn stover) and other related considerations for the overall biorefinery supply chain.

Accordingly, the present integrated pathway demonstrates potential for substantially higher fuel yields than the pathways presented in the 2018 design report: roughly 61 GGE/ton versus $43-45$ GGE/ton (36\%-42\% increase) [1]. Such a high fuel yield is not commonly encountered in a biochemical processing approach when focused only on the carbohydrate fraction of the biomass feedstock and is largely achieved owing to high carbon retention efficiencies across the furan catalytic upgrading steps by rejecting oxygen as water rather than $\mathrm{CO}_{2}$. The dedicated biorefinery case could achieve even higher fuel yields of $108 \mathrm{GGE} /$ ton, but as noted, this may be somewhat artificial as the ketone likely must be derived from a low-carbon-intensity source, and if this were through a biomass conversion process the overall system yield would still be near the 61-GGE/ton basis. This is a similar finding as a previously investigated design report focused on catalytic upgrading of sugars to hydrocarbon fuels via aqueous-phase reforming technology, which also maintained high carbon 
efficiencies through low $\mathrm{CO}_{2}$ rejection and had found the potential for fuel yields as high as 78 GGE/ton when sourcing hydrogen externally, reducing to $45 \mathrm{GGE} /$ ton with in situ hydrogen sourcing through a parallel carbohydrate upgrading train [4]. The main data for key process streams are presented in Appendix C.

Although these results demonstrate the potential for exceptionally high fuel yields through this pathway, they also carry higher processing costs than the pathways documented in the 2018 design report. Namely, capital expenditures based on TCI are between 4\% and 13\% higher than the 2018 design case pathways (\$786-\$787 MM for the two scenarios here versus \$697-\$758 MM for the 2018 cases), although this still supports lower MFSPs as it translates to a TCI per annual gallon of $\$ 10 /$ GGE (dedicated case) and \$18/GGE (integrated case) versus the 2018 cases at $\$ 22-\$ 23 /$ GGE. However, net operating expenses are also higher, at $\$ 96 \mathrm{MM} / \mathrm{yr}$ (dedicated case) and $\$ 19 \mathrm{MM} / \mathrm{yr}$ (integrated case) versus negative $\$ 15-\$ 18 \mathrm{MM} / \mathrm{yr}$ inclusive of variable and fixed operating costs and coproduct credits. This is driven primarily by increased costs for hydrogen and natural gas required for the catalytic upgrading operations, together adding roughly $\$ 0.75 / \mathrm{GGE}$ and $\$ 0.95 / \mathrm{GGE}$ between both biorefinery scenarios, respectively.

As is typical for TEA models, feedstock constitutes the largest single MFSP contribution at roughly $\$ 0.66 /$ GGE and $\$ 1.17 /$ GGE for the dedicated and integrated scenarios respectively. In the dedicated case, externally purchased MEK also incurs large costs at \$0.62/GGE. Similar to the 2018 design report, the ability to reduce MFSPs down to $\$ 3 / \mathrm{GGE}$ or lower is strongly contingent on valorizing the lignin fraction of the biomass for conversion to value-added coproducts, reducing net MFSPs by $\$ 1.24 / \mathrm{GGE}$ and $\$ 2.17 / \mathrm{GGE}$ in the dedicated and integrated cases, respectively. In either case, annual coproduct revenues are comparable to each other as well as (slightly more than) the 2018 design case pathways but appear lower on a per-GGE basis given the higher fuel yields in the present models, particularly for the dedicated biorefinery case. Ultimately, this means that the higher fuel yields translate favorably to a lower reliance on lignin-derived coproducts to achieve MFSP goals below $\$ 3 / \mathrm{GGE}$, albeit trading off other challenges with higher facility operating expenses.

\section{Analysis and Discussion}

\subsection{Carbon Balance}

Table 22 shows the overall flow of carbon inputs and outputs, with a carbon balance closure very near unity (difference of approximately $0.2 \%$ ). The biorefining cases assessed in this report differ significantly in terms of carbon input and utilization. It is also noteworthy to highlight that the dedicated and the integrated biorefineries process, respectively, $27 \%$ and $17 \%$ more carbon in comparison to the pathways presented in the 2018 design report. Apart from biomass, which makes up around $76 \%$ and $86 \%$ of the total processed carbon in the dedicated and integrated cases, respectively, both plants import a considerable amount of natural gas to be combusted in the boiler to supply process heat requirements. Additionally, the dedicated biorefinery imports around $13 \%$ of the total carbon in the form of methyl ethyl ketone for the aldol condensation reaction in Area 500. Other inputs (glucose and other chemicals) are minor contributors to the carbon balance. In terms of outputs, fermentor vents and other process off-gases are sent to the boiler in Area 800 and are accounted as flue gas. In the dedicated case, nearly $60 \%$ of the total carbon input leaves as the hydrocarbon fuel and the adipic acid coproduct. This high carbon conversion efficiency is due to the high yields of the reactions considered in Area 500 and to the effective merging of carbon in methyl ethyl ketone (external input) into the hydrocarbon fuel product. In the integrated case, the combined products account for around 
$42 \%$ of the total carbon input, which is a result from relying solely on the biomass feedstock to synthesize both furans and ketone to generate the hydrocarbon fuel. Other large carbon outlets in the biorefineries are the combustor stack and the aerobic digestion lagoons.

Table 22. Overall Carbon Balance for the Biorefineries

\begin{tabular}{lcccc}
\hline & \multicolumn{2}{c}{ Dedicated Case } & \multicolumn{2}{c}{ Integrated Case } \\
\hline Stream & $\begin{array}{c}\text { Carbon Flow } \\
(\mathrm{kmol} / \mathrm{h})\end{array}$ & $\begin{array}{c}\% \text { of Carbon } \\
\text { Flow }\end{array}$ & $\begin{array}{c}\text { Carbon Flow } \\
(\mathrm{kmol} / \mathrm{h})\end{array}$ & $\begin{array}{c}\% \text { of Carbon } \\
\text { Flow }\end{array}$ \\
\hline \multicolumn{1}{c}{ Carbon inlets } & & & & \\
\hline Biomass feedstock & 3,087 & $76 \%$ & 3,087 & $82 \%$ \\
Natural gas & 406 & $10 \%$ & 605 & $16 \%$ \\
Methyl ethyl ketone & 516 & $13 \%$ & - & - \\
Glucose & 44 & $1 \%$ & 44 & $1 \%$ \\
Other chemical inputs & 15 & $<1 \%$ & 13 & $<1 \%$ \\
\hline Total & 4,068 & $100 \%$ & 3,749 & $100 \%$ \\
\hline \multicolumn{1}{c}{ Carbon outlets } & \multicolumn{4}{c}{} \\
\hline Area 500 fuel output & 1,961 & $48 \%$ & 1,106 & $29 \%$ \\
Area 700 coproduct & 487 & $12 \%$ & 474 & $13 \%$ \\
Combustor flue gas & 1,571 & $39 \%$ & 2,001 & $53 \%$ \\
Aerobic lagoons & 55 & $1 \%$ & 175 & $5 \%$ \\
\hline Total & 4,074 & $100 \%$ & 3,756 & $100 \%$ \\
\hline
\end{tabular}

\subsection{Cost Sensitivity Analysis}

For each of the biorefining strategies discussed previously in the report, the techno-economic models were used to carry out sensitivity analyses on key model variables. Starting with the baseline for each variable as described in this report, minimum and maximum values were chosen to assess their impact on the MFSP of the whole process one parameter at a time, with all other variables held constant. The goal of the analyses presented herein is to focus on parameters linked to Areas 500/550 and on other variables that could have an impact on either plant when considering the full biorefining context. Some of the most significant drivers of MFSP in the 2018 design report were chosen to be included in this assessment (e.g., $\mathrm{NaOH}$ loading in DMR, enzyme loading in enzymatic hydrolysis, and factors related to lignin utilization in Area 700).

\subsubsection{Single-Point Sensitivity Analysis: Dedicated Case}

Table 22 presents the studied variables, their baseline values, and the associated minima/maxima for the dedicated biorefinery, whereas Figure 14 displays the sensitivities of MFSP in a tornado plot. The variables are ranked in order of the extent of their impact, from largest to smallest.

The largest impact on MFSP was due to the uncertainty in adipic acid price, which was varied in the same price range as that presented in the 2018 design report $(\$ 0.50-\$ 1.25 / 1 \mathrm{~b})$. Coproduct credits generated in a biorefinery context are an important strategy to help cellulosic fuels achieve MFSP under \$2.50/GGE. MEK price, a significant component of the biorefinery's OPEX, could also be a major cost driver if chemical-grade MEK was to be purchased in the market (this was debated in Section 4.2). Accordingly, if another low-cost source of MEK was to be developed, such as through the conversion of carboxylic acids from wastewater-based arrested anaerobic digestion, the MFSP could be further improved by $\$ 0.21 /$ GGE if MEK was to be purchased at $\$ 0.20 / \mathrm{lb}$. The furan yield from sugar dehydration also influences MFSP results due to a reduction in fuel yield (from 78.5 MM 
GGE/year in the base case to $62.8 \mathrm{MM} \mathrm{GGE/year} \mathrm{in} \mathrm{the} 80 \%$ molar yield sensitivity case), which ends up increasing costs on a per-GGE basis. The uncertainty in capital cost associated with the approach used in this study ( $\pm 25 \%$ TCI) shows the fourth-largest impact on MFSP. Next, parameters tied to the lignin valorization sections (such as muconic acid productivity during aerobic fermentation and the amount of biologically accessible lignin) also have a significant impact because they directly affect the amount of adipic acid that could be sold as a high-value coproduct. Other variables, including those related specifically to the fuel train, have less pronounced influence over MFSP. For information purposes, natural gas prices were varied between $\$ 3$ and $\$ 5 / \mathrm{MM}$ BTU, which represents the general price range in the last 8 years [20]. Because hydrogen is considered to be produced via steam methane reforming, its purchase price was varied between $\$ 0.55$ and $\$ 0.91 / 1 \mathrm{~b}$, corresponding to the minimum and maximum natural gas prices of $\$ 3$ and $\$ 5 / \mathrm{MM} B T U$, respectively.

Table 23. Assumptions Varied in the Sensitivity Analysis of the Dedicated Biorefinery

\begin{tabular}{|c|c|c|c|c|}
\hline & Assumption & Min MFSP & Baseline & Max MFSP \\
\hline Pretreatment & DMR NaOH loading $(\mathrm{mg} / \mathrm{g})$ & 50 & 70 & 100 \\
\hline \multirow{3}{*}{$\begin{array}{l}\text { Enzymatic } \\
\text { Hydrolysis and } \\
\text { Conditioning }\end{array}$} & Vacuum filter press capital cost & $-50 \%$ & - & $+50 \%$ \\
\hline & Flocculant loading (g/kg solid) & 10 & 20 & 30 \\
\hline & Enzymatic hydrolysis enzyme loading $(\mathrm{mg} / \mathrm{g})$ & 5 & 10 & 20 \\
\hline \multirow{9}{*}{$\begin{array}{l}\text { Furans } \\
\text { Production and } \\
\text { Upgrading }\end{array}$} & Sugar dehydration to furans (molar yield) & - & $100 \%$ & $80 \%$ \\
\hline & Dehydration reaction residence time (min) & - & 5 & 10 \\
\hline & Dioxane:hydrolysate loading (v/v) & $1.0: 1$ & $1.5: 1$ & - \\
\hline & $\mathrm{NaOH}$ loading $(\mathrm{g} / \mathrm{L})$ & - & 3.6 & 7 \\
\hline & HDO:decarbonylation split in hydrotreating & - & $100: 0$ & 90:10 \\
\hline & Hydrotreating reactor capital cost & $-50 \%$ & - & $50 \%$ \\
\hline & Hydrotreating WHSV $\left(\mathrm{h}^{-1}\right)$ & 10 & 2 & 1 \\
\hline & Furans production train capital cost & $-50 \%$ & - & $50 \%$ \\
\hline & MEK price $(\$ / l b)$ & 0.20 & 0.30 & 0.77 \\
\hline \multirow[t]{3}{*}{ Lignin Utilization } & Muconic productivity (g/L/h) & 2 & 1 & 0.5 \\
\hline & Metabolically accessible lignin (wt\%) & 0.675 & 0.533 & 0.405 \\
\hline & Adipic acid price $(\$ / / b)$ & 1.25 & 0.86 & 0.50 \\
\hline \multirow[t]{4}{*}{ Economics } & Total capital investment & $-25.0 \%$ & - & $25.0 \%$ \\
\hline & Feedstock cost (\$/dry ton) & 60 & 71.26 & 80 \\
\hline & Hydrogen price $(\$ / / \mathrm{b})$ & 0.55 & 0.73 & 0.91 \\
\hline & Natural gas price (\$/MM BTU) & 3 & 3.50 & 5 \\
\hline
\end{tabular}




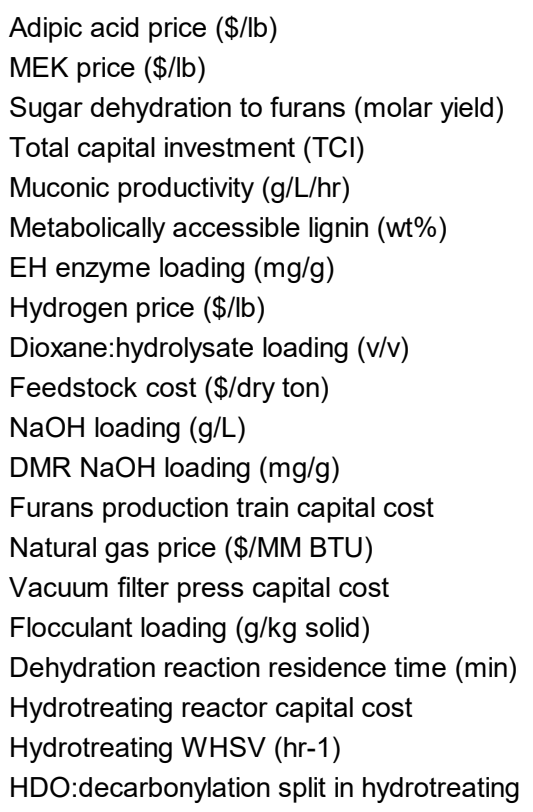

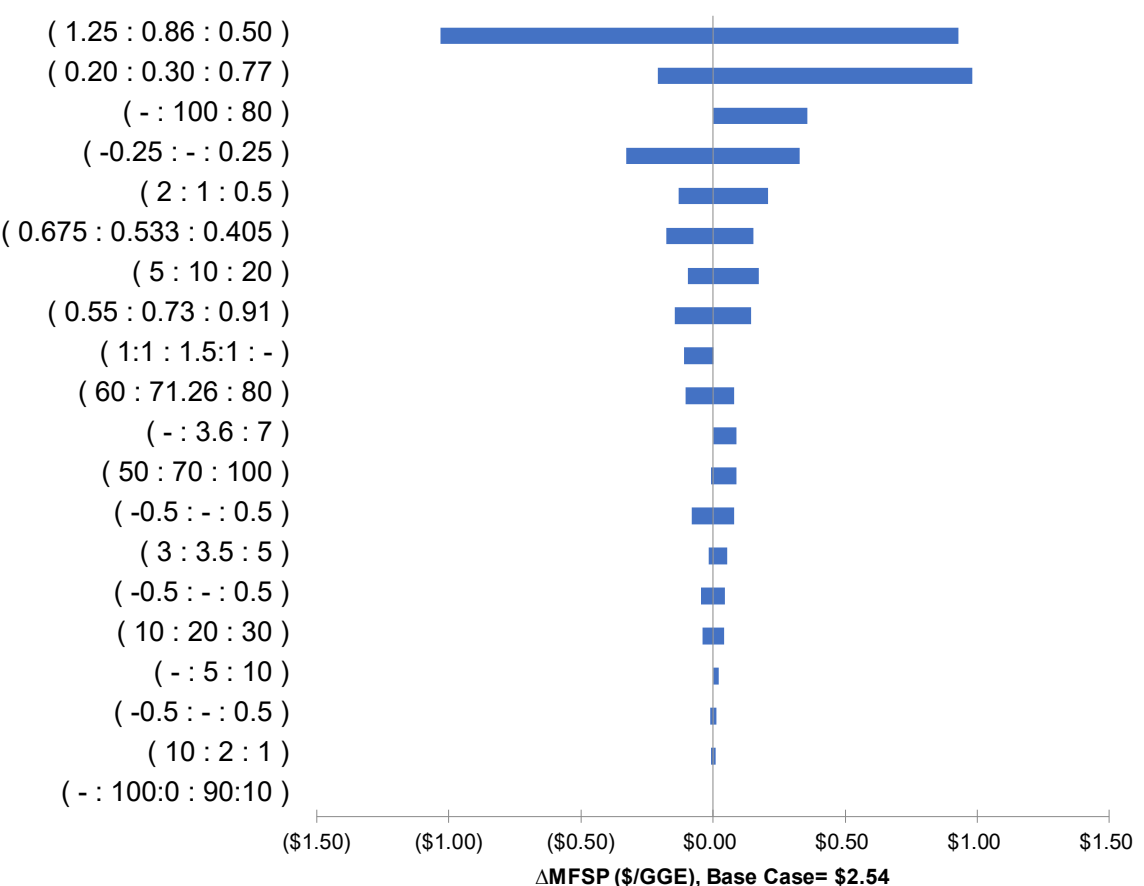

Figure 14. Dedicated biorefinery single-point sensitivity tornado chart for MFSP

\subsubsection{Single-Point Sensitivity Analysis: Integrated Case}

As for the dedicated biorefinery, Table 24 lists the studied variables, their baseline values, and the associated minima/maxima for the sensitivity analysis of the integrated plant. Figure 15 then presents the tornado plot for sensitivities of MFSP.

In a similar way to the dedicated case, the selling price associated with adipic acid is the main factor in the sensitivity analysis for the integrated biorefinery. This supports the narrative of needing to add value to all biomass fractions so fuel production from cellulosic biomass can reach low MFSP targets. Other factors (TCI, furan yield from sugar dehydration, and parameters linked to lignin fermentation) are also ranked high in their influence over MFSP for the same reasons as discussed in the previous section. 
Table 24. Assumptions Varied in the Sensitivity Analysis of the Integrated Biorefinery

\begin{tabular}{|c|c|c|c|c|}
\hline & Assumption & Min MFSP & Baseline & Max MFSP \\
\hline Pretreatment & DMR NaOH loading $(\mathrm{mg} / \mathrm{g})$ & 50 & 70 & 100 \\
\hline \multirow{3}{*}{$\begin{array}{l}\text { Enzymatic } \\
\text { Hydrolysis and } \\
\text { Conditioning }\end{array}$} & Vacuum filter press capital cost & $-50 \%$ & - & $+50 \%$ \\
\hline & Flocculant loading (g/kg solid) & 10 & 20 & 30 \\
\hline & Enzymatic hydrolysis enzyme loading $(\mathrm{mg} / \mathrm{g})$ & 5 & 10 & 20 \\
\hline \multirow{8}{*}{$\begin{array}{l}\text { Furans } \\
\text { Production and } \\
\text { Upgrading }\end{array}$} & Sugar dehydration to furans (molar yield) & - & $100 \%$ & $80 \%$ \\
\hline & Dehydration reaction residence time (min) & - & 5 & 10 \\
\hline & Dioxane:hydrolysate loading (v/v) & $1.0: 1$ & $1.5: 1$ & - \\
\hline & $\mathrm{NaOH}$ loading $(\mathrm{g} / \mathrm{L})$ & - & 3.6 & 7 \\
\hline & HDO:decarbonylation split in hydrotreating & - & $100: 0$ & $90: 10$ \\
\hline & Hydrotreating reactor capital cost & $-50 \%$ & - & $50 \%$ \\
\hline & Hydrotreating WHSV $\left(\mathrm{h}^{-1}\right)$ & 10 & 2 & 1 \\
\hline & Furans production train capital cost & $-50 \%$ & - & $50 \%$ \\
\hline \multirow{4}{*}{$\begin{array}{l}\text { BDO Fermentation } \\
\text { and MEK } \\
\text { Production }\end{array}$} & Fermentation glucose to product (wt\%) & $100 \%$ & $95 \%$ & $85 \%$ \\
\hline & BDO to MEK (molar yield) & 0.90 & 0.803 & 0.75 \\
\hline & BDO upgrading WHSV $\left(\mathrm{h}^{-1}\right)$ & 1 & 0.24 & 0.1 \\
\hline & BDO/MEK train capital cost & $-50 \%$ & - & $50 \%$ \\
\hline \multirow[t]{3}{*}{ Lignin Utilization } & Muconic productivity (g/L/h) & 2 & 1 & 0.5 \\
\hline & Metabolically accessible lignin (wt\%) & 0.675 & 0.533 & 0.405 \\
\hline & Adipic acid price $(\$ / \mathrm{lb})$ & 1.25 & 0.86 & 0.50 \\
\hline \multirow[t]{3}{*}{ Economics } & Total capital investment & $-25.0 \%$ & - & $25.0 \%$ \\
\hline & $\begin{array}{l}\text { Feedstock cost (\$/dry ton) } \\
\text { Hydrogen price }(\$ / / \mathrm{b})\end{array}$ & $\begin{array}{c}60 \\
0.55\end{array}$ & $\begin{array}{c}71.26 \\
0.73\end{array}$ & $\begin{array}{c}80 \\
0.91\end{array}$ \\
\hline & Natural gas price (\$/MM BTU) & 3 & 3.50 & 5 \\
\hline
\end{tabular}

Adipic acid price $(\$ / \mathrm{lb})$

Total capital investment (TCl)

Muconic productivity ( $\mathrm{g} / \mathrm{L} / \mathrm{hr}$ )

Sugar dehydration to furans (molar yield)

EH enzyme loading $(\mathrm{mg} / \mathrm{g})$

Metabolically accessible lignin (wt\%)

Dioxane:hydrolysate loading $(\mathrm{v} / \mathrm{v})$

BDO upgrading to MEK (molar yield)

Feedstock cost (\$/dry ton)

DMR $\mathrm{NaOH}$ loading $(\mathrm{mg} / \mathrm{g})$

Hydrogen price $(\$ / \mathrm{lb})$

Natural gas price (\$/MM BTU)

Furans production train capital cost

BDO/MEK train capital cost

$\mathrm{NaOH}$ loading $(\mathrm{g} / \mathrm{L})$

Fermentation glucose to product (wt\%)

Vacuum filter press capital cost

Flocculant loading ( $\mathrm{g} / \mathrm{kg}$ solid)

Dehydration reaction residence time (min)

BDO upgrading WHSV (hr-1)

Hydrotreating reactor capital cost

Hydrotreating WHSV (hr-1)

HDO:decarbonylation split in hydrotreating
$(1.25: 0.86: 0.50)$

$(-0.25:-: 0.25)$

$(2: 1: 0.5)$

$(-: 100: 80)$

$(5: 10: 20)$

$(0.675: 0.533: 0.405)$

$(1: 1: 1.5: 1:-)$

$(90: 80.3: 75)$

$(60: 71.26: 80)$

$(50: 70: 100)$

$(0.55: 0.73: 0.91)$

$(3: 3.5: 5)$

$(-0.5:-: 0.5)$

$(-0.5:-: 0.5)$

$(-: 3.6: 7)$

$(100: 95: 85)$

$(-0.5:-: 0.5)$

$(10: 20: 30)$

$(-: 5: 10)$

$(10: 2.4: 1)$

$(-0.5:-: 0.5)$

$(10: 2: 1)$

$(-: 100: 0: 90: 10)$ $\begin{array}{lllllllll}(\$ 2.00) & (\$ 1.50) & (\$ 1.00) & (\$ 0.50) & \$ 0.00 & \$ 0.50 & \$ 1.00 & \$ 1.50 & \$ 2.00\end{array}$

$\triangle$ MFSP (\$/GGE), Base Case $=\$ 2.72$

Figure 15. Integrated biorefinery single-point sensitivity tornado chart for MFSP 


\subsubsection{Case Study: Experimental Baseline}

A case study reflective of the current level of experimental development linked to sugar dehydration, aldol condensation, and hydrotreating (all represented in Area 500 of the biorefineries) has also been conducted. By combining factors already explored in Sections 5.2.1 and 5.2.2 and summarized in Table 25, two new scenarios were generated, one for each biorefining setup, dedicated or integrated. They are deemed to be representative of the experimental baseline of the furans pathway prioritized under CUBI. For the comparison, all other parameters have been kept the same as in the base case (e.g., biomass deconstruction, lignin upgrading, and auxiliary sections).

Table 25. Parameters Varied in the Assessment of the Current Experimental Baseline

\begin{tabular}{|c|c|c|}
\hline Parameter & Target case $(2030)$ & $\begin{array}{c}\text { Current experimental } \\
\text { baseline }\end{array}$ \\
\hline \multicolumn{3}{|l|}{ Dehydration } \\
\hline HMF from C6 sugars (molar yield) & $100 \%$ & $72 \%$ \\
\hline Furfural from C5 sugars (molar yield) & $100 \%$ & $90 \%$ \\
\hline Reaction time (min) & 5 & 15 \\
\hline \multicolumn{3}{|l|}{ Aldol condensation } \\
\hline $\mathrm{NaOH}$ loading $(\mathrm{g} / \mathrm{L})$ & 3.6 & 7.0 \\
\hline \multicolumn{3}{|l|}{ Hydrotreating } \\
\hline Hydrotreating catalyst & $1 \% \mathrm{Pd} / \mathrm{Al}_{2} \mathrm{O}_{3}-\mathrm{SiO}_{2}$ & $5 \% \mathrm{Pd} / \mathrm{Al}_{2} \mathrm{O}_{3}-\mathrm{SiO}_{2}$ \\
\hline HDO:decarbonylation split in hydrotreating & $100: 0$ & $90: 10$ \\
\hline
\end{tabular}

Table 26 shows the results for the dedicated biorefinery using current experimental parameters. The estimated MFSP is up to $\$ 3.14 / \mathrm{GGE}$, a delta of $\$ 0.60 /$ GGE. Following the discussion in Section 5.2.1, a reduction in the production of furans during sugar dehydration leads to a significant drop in fuel output (down by $12 \%$ to $61.4 \mathrm{MM} \mathrm{GGE/year)} \mathrm{and} \mathrm{ends} \mathrm{up} \mathrm{being} \mathrm{the} \mathrm{main} \mathrm{cost} \mathrm{driver} \mathrm{among} \mathrm{the} \mathrm{set} \mathrm{of}$ variables in Table 25.

Table 26. Summary of Yields, Rates, and Conversion Costs for the Dedicated Biorefinery Using Current Experimental Parameters

\begin{tabular}{lcc}
\hline & \multicolumn{2}{c}{ Dedicated biorefinery } \\
\hline Feedstock rate & Target case (2030) & Current experimental baseline \\
Online time & $2,205 \mathrm{dry}$ U.S. tons/day \\
Total fuel yield & $7,884 \mathrm{~h} / \mathrm{yr}(90 \%$ online factor) \\
Total fuel production rate & $108.4 \mathrm{GGE} / \mathrm{dry}$ U.S. ton feedstock & $84.7 \mathrm{GGE} / \mathrm{dry}$ U.S. ton feedstock \\
Adipic acid coproduct yield & $78.5 \mathrm{MM} \mathrm{GGE/yr}$ & $61.4 \mathrm{MM} \mathrm{GGE} / \mathrm{yr}$ \\
Adipic acid production rate & $284 \mathrm{lb} / \mathrm{dry}$ U.S. ton feedstock & $284 \mathrm{lb} / \mathrm{dry}$ U.S. ton feedstock \\
Total variable OPEX excluding coproducts & $205 \mathrm{MM} \mathrm{Ib/yr}$ & $205 \mathrm{MM} \mathrm{Ib/yr}$ \\
Coproduct revenue & $\$ 269 \mathrm{MM} / \mathrm{yr}$ & $\$ 255 \mathrm{MM} / \mathrm{yr}$ \\
Total fixed OPEX & $\$ 193 \mathrm{MM} / \mathrm{yr}$ & $\$ 190 \mathrm{MM} / \mathrm{yr}$ \\
Total equipment cost & $\$ 20 \mathrm{MM} / \mathrm{yr}$ & $\$ 21 \mathrm{MM} / \mathrm{yr}$ \\
Total capital investment & $\$ 414 \mathrm{MM}$ & $\$ 430 \mathrm{MM}$ \\
TCl per annual gallon & $\$ 787 \mathrm{MM}$ & $\$ 815 \mathrm{MM}$ \\
Minimum Fuel Selling Price & $\$ 10.02 / \mathrm{GGE}$ & $\$ 13.28 / \mathrm{GGE}$ \\
Feedstock contribution & $\$ 2.54 / \mathrm{GGE}$ & $\$ 3.14 / \mathrm{GGE}$ \\
Fuel conversion contribution & $\$ 0.66 / \mathrm{GGE}$ & $\$ 0.84 / \mathrm{GGE}$ \\
Coproduct conversion contribution & $\$ 3.11 / \mathrm{GGE}$ & $\$ 3.87 / \mathrm{GGE}$ \\
\hline
\end{tabular}


The results obtained for the case study related to the integrated biorefinery are summarized in Table 27. The assessment determined an MFSP of $\$ 3.31 / \mathrm{GGE}$ when considering current experimental data, corresponding to an increase of $\$ 0.59 / \mathrm{GGE}$ in comparison to the target case. A similar reasoning as for the dedicated biorefinery can be applied to explain the results, which are mainly dependent on lower fuel yields and higher processing costs.

Table 27. Summary of Yields, Rates, and Conversion Costs for the Integrated Biorefinery Using Current Experimental Parameters

\begin{tabular}{|c|c|c|}
\hline & \multicolumn{2}{|c|}{ Integrated biorefinery } \\
\hline & Target case (2030) & Current experimental baseline \\
\hline Feedstock rate & \multicolumn{2}{|c|}{ 2,205 dry U.S. tons/day } \\
\hline Online time & \multicolumn{2}{|c|}{$7,884 \mathrm{~h} / \mathrm{yr}$ (90\% online factor) } \\
\hline Total fuel yield & 61.2 GGE/dry U.S. ton feedstock & 52.6 GGE/dry U.S. ton feedstock \\
\hline Total fuel production rate & 44.3 MM GGE/yr & 38.1 MM GGE/yr \\
\hline Adipic acid coproduct yield & $276 \mathrm{lb} / \mathrm{dry}$ U.S. ton feedstock & $277 \mathrm{lb} / \mathrm{dry}$ U.S. ton feedstock \\
\hline Adipic acid production rate & $200 \mathrm{MM} \mathrm{lb} / \mathrm{yr}$ & $201 \mathrm{MM} \mathrm{lb} / \mathrm{yr}$ \\
\hline Total variable OPEX excluding coproducts & $\$ 187 \mathrm{MM} / \mathrm{yr}$ & $\$ 187 \mathrm{MM} / \mathrm{yr}$ \\
\hline Coproduct revenue & $\$ 188 \mathrm{MM} / \mathrm{yr}$ & $\$ 187 \mathrm{MM} / \mathrm{yr}$ \\
\hline Total fixed OPEX & $\$ 20 \mathrm{MM} / \mathrm{yr}$ & $\$ 21 \mathrm{MM} / \mathrm{yr}$ \\
\hline Total equipment cost & $\$ 416 \mathrm{MM}$ & $\$ 429 \mathrm{MM}$ \\
\hline Total capital investment & $\$ 786 \mathrm{MM}$ & $\$ 811 \mathrm{MM}$ \\
\hline $\mathrm{TCl}$ per annual gallon & $\$ 17.75 / G G E$ & $\$ 21.32 / G G E$ \\
\hline Minimum Fuel Selling Price & $\$ 2.72 / G G E$ & $\$ 3.31 / G G E$ \\
\hline Feedstock contribution & \$1.17/GGE & $\$ 1.36 / G G E$ \\
\hline Fuel conversion contribution & $\$ 3.71 / G G E$ & $\$ 4.49 / G G E$ \\
\hline Coproduct conversion contribution & $-\$ 2.16 / G G E$ & $-\$ 2.53 / G G E$ \\
\hline
\end{tabular}

Results could be slightly improved if anaerobic digestion were employed as an additional step in WWT to harness part of the chemical oxygen demand present in the wastewater leaving Area 500 due to the partial conversion of sugars into furans. Carbon in that stream could be converted into biogas to help offset natural gas purchase to fuel the boiler section.

\subsubsection{Case Study: BDO Fermentation with Clarified Hydrolysate}

The final case study investigates the effect of changing the substrate for BDO fermentation in Area 550 from whole slurry (still with lignin mixed with sugars) to a clarified hydrolysate. Based on guidance from the research and development team, conducting fermentation on clarified sugars tends to be preferred over whole-slurry strategies in future experimental developments. The absence of lignin in the fermentors could improve substrate homogeneity and mass-transfer properties. Using a clarified hydrolysate could also allow for the recycle of cells in fermentation approaches that require this feature. The exact economic impact of these possibility is yet to be determined.

In this case study, clarified hydrolysate, both prior and after evaporation, is diverted to BDO fermentation instead of whole-slurry hydrolysate. Figure 16 presents the points at which sugar is retrieved in Area 300. In the simulation, 19.8\% from the dilute hydrolysate and $30.2 \%$ from the concentrated sugar stream are sent to Area 550, resulting in a final sugar split of 56\% to Area 500 and $44 \%$ to Area 550. For consistency purposes, BDO titer was maintained at $97 \mathrm{~g} / \mathrm{L}$ as in the 2018 design report and in the base integrated biorefinery assessed in this report, both carried out with whole-slurry fermentation. Finally, the lignin press required for solids removal after whole-slurry fermentation in 
the base case is forfeited in this case study. Table 28 summarizes the main results from the TEA comparing both scenarios of the integrated biorefinery.

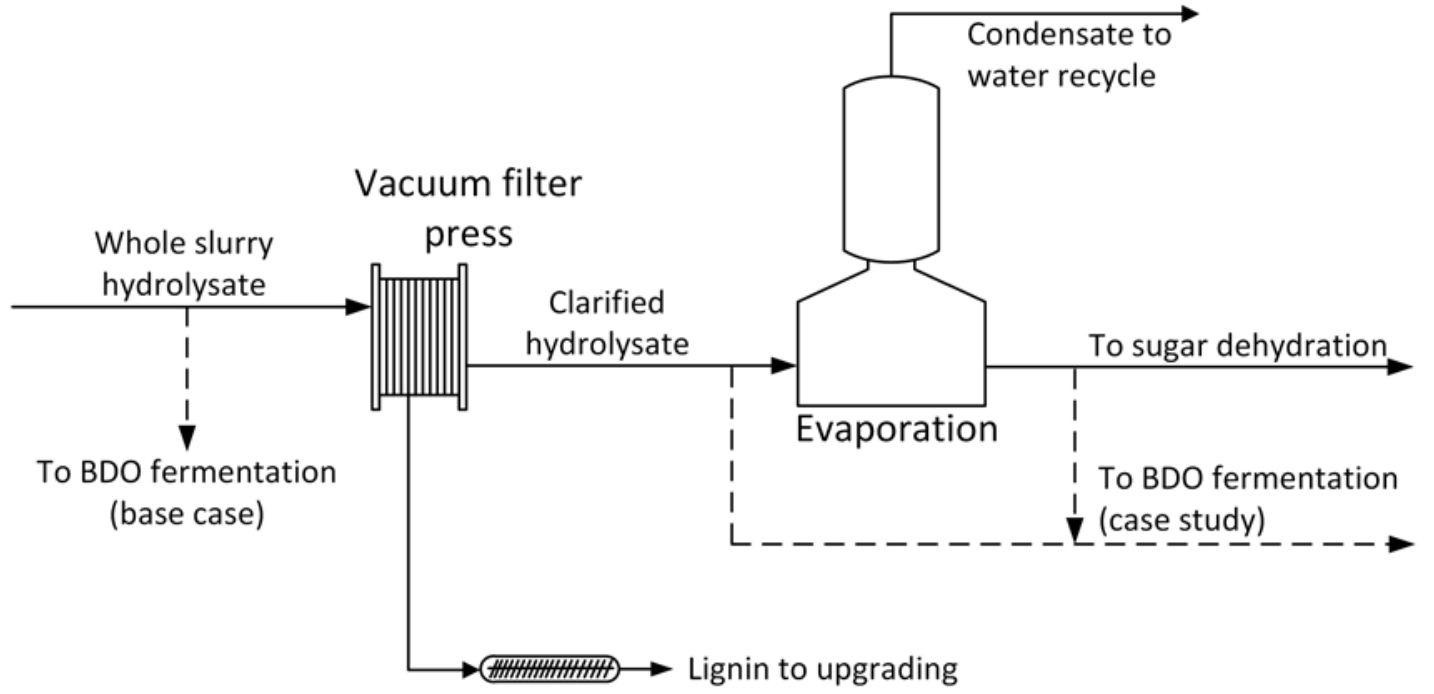

Figure 16. Diagram depicting the points in Area 300 at which sugars are diverted to BDO fermentation. The base case utilizes whole-slurry hydrolysate, whereas the case study employs a combination of diluted and concentrated clarified hydrolysate.

Table 28. Summary of Yields, Rates, and Conversion Costs for the Case Study on Clarified Hydrolysate Utilization

\begin{tabular}{|c|c|c|}
\hline & \multicolumn{2}{|c|}{ BDO fermentation substrate } \\
\hline & $\begin{array}{l}\text { Whole slurry } \\
\text { (base case) }\end{array}$ & $\begin{array}{c}\text { Clarified hydrolysate } \\
\text { (case study) }\end{array}$ \\
\hline Feedstock rate & \multicolumn{2}{|c|}{2,205 dry U.S. tons/day } \\
\hline Online time & \multicolumn{2}{|c|}{$7,884 \mathrm{~h} / \mathrm{yr}(90 \%$ online factor) } \\
\hline Total fuel yield & $\begin{array}{l}61.2 \text { GGE/dry U.S. ton } \\
\text { feedstock }\end{array}$ & $\begin{array}{c}\text { 60.7 GGE/dry U.S. ton } \\
\text { feedstock }\end{array}$ \\
\hline Total fuel production rate & 44.3 MM GGE/yr & 44.0 MM GGE/yr \\
\hline Adipic acid coproduct yield & $276 \mathrm{lb} / \mathrm{dry}$ U.S. ton feedstock & $284 \mathrm{lb} / \mathrm{dry}$ U.S. ton feedstock \\
\hline Adipic acid production rate & $200 \mathrm{MM} \mathrm{lb} / \mathrm{yr}$ & $205 \mathrm{MM} \mathrm{lb} / \mathrm{yr}$ \\
\hline Total variable OPEX excluding coproducts & $\$ 187 \mathrm{MM} / \mathrm{yr}$ & $\$ 191 \mathrm{MM} / \mathrm{yr}$ \\
\hline Coproduct revenue & $\$ 188 \mathrm{MM} / \mathrm{yr}$ & $\$ 193 \mathrm{MM} / \mathrm{yr}$ \\
\hline Total fixed OPEX & $\$ 20 \mathrm{MM} / \mathrm{yr}$ & $\$ 21 \mathrm{MM} / \mathrm{yr}$ \\
\hline Total equipment cost & $\$ 416 \mathrm{MM}$ & $\$ 432 \mathrm{MM}$ \\
\hline Total capital investment & $\$ 786 \mathrm{MM}$ & $\$ 818 \mathrm{MM}$ \\
\hline $\mathrm{TCl}$ per annual gallon & $\$ 17.75 / G G E$ & $\$ 18.59 / G G E$ \\
\hline Minimum Fuel Selling Price & $\$ 2.72 / G G E$ & $\$ 2.81 / G G E$ \\
\hline Feedstock contribution & $\$ 1.17 / G G E$ & $\$ 1.17 / G G E$ \\
\hline Fuel conversion contribution & $\$ 3.71 /$ GGE & $\$ 3.86 / G G E$ \\
\hline Coproduct conversion contribution & $-\$ 2.16 / G G E$ & $-\$ 2.22 / G G E$ \\
\hline
\end{tabular}

The main result of the analysis is an MFSP that is only $\$ 0.09 / \mathrm{GGE}$ higher in comparison to the base integrated plant, amounting to $\$ 2.81 / \mathrm{GGE}$. The clarified hydrolysate case has higher processing costs, both in terms of OPEX in the form of flocculant usage and electricity consumption, and in terms of capital investment due to the need for a large-sized VFP (\$14-MM installed cost VFP in the base case, 
which rises to $\$ 24 \mathrm{MM}$ in the updated case study). There are only marginal gains ( $\$ 0.06 / \mathrm{GGE})$ from additional adipic acid production. Also, it is worth noting that the increase of $\$ 0.09 / \mathrm{GGE}$ in MFSP due to the use of a VFP to clarify the slurry leaving the enzymatic hydrolysis is specific to this hybrid biorefining setup (considering both fermentation- and catalytic-based processes to convert sugars into hydrocarbon fuels). The result should be more pronounced in a purely fermentation-centered plant, such as that assessed in the 2018 design report for the BDO case. The main reason for this conclusion is essentially the lower fuel yields attained by such biorefineries, which would translate to a higher increase in processing cost on a per-GGE basis.

Provided that future experimental efforts with BDO fermentation (and that of other metabolites) will likely be increasingly based on clarified hydrolysates in detriment of the whole slurry, researchers should be aware of the potential TEA ramifications linked to choosing this strategy. Future TEA efforts could be devoted to examining in detail the impacts of switching to this strategy; for example, understanding the benefits of combining batch hydrolysis with VFP vs. whole-slurry BDO fermentation or continuous enzymatic hydrolysis and fermentation to carboxylic acids (cases described in the 2018 design report).

\subsection{Sustainability Metric Indicators}

This section presents primary sustainability metric indicators of the current conceptual process at the conversion stage derived from Aspen Plus simulations. Table 29 summarizes the key sustainability metric indicators for the two biorefining strategies assessed in this report. The processes differ significantly in terms of fuel yield, carbon efficiency to fuels, and natural gas imports. The dedicated biorefinery benefits from the purchase of externally sourced MEK to improve fuel yields to beyond $108 \mathrm{GGE} /$ dry ton of biomass. In this plant, $26 \%$ of the carbon in the hydrocarbon fuel comes from the ketone, while the remainder is obtained from the biomass via the catalytic conversion of sugars. For the integrated plant, the fuel yield is $61 \mathrm{GGE} /$ dry ton of biomass because it split efforts in obtaining both classes of compounds (furans and ketones) needed in the aldol condensation reaction. The overall combined carbon efficiency (to fuel and adipic acid) for the dedicated and integrated plants are $62.6 \%$ and $51.1 \%$, respectively, considering only the carbon in the biomass feedstock. Both plants are energy-intensive and require natural gas supplementation in the boiler to supply the high energy demand. Finally, net water consumption is nearly $7,000 \mathrm{~m}^{3}$ per day for either plant, which is high in absolute terms but comparable to the pathways in the 2018 design report on a per-GGE basis.

Table 29. Summary of Sustainability Metric Indicators for the Modeled Biorefining Configurations

\begin{tabular}{|l|l|c|c|}
\cline { 3 - 4 } \multicolumn{2}{c|}{} & \multicolumn{2}{c|}{ Biorefinery } \\
\hline Sustainability Metrics & GGE per dry ton biomass & 108.4 & Integrated \\
\hline Fuel yield by weight of biomass & $\%$ C in biomass & 46.8 & 35.8 \\
\hline Carbon efficiency to fuels & $\%$ C in biomass & 15.8 & 15.3 \\
\hline Carbon efficiency to adipic acid & $\mathrm{kWh} / \mathrm{GGE}$ & 5.2 & 6.4 \\
\hline Electricity import & $\mathrm{MJ} / \mathrm{GGE}$ & 36.3 & 96.0 \\
\hline Natural gas import & gal/GGE & 7.4 & 13.4 \\
\hline Water consumption & $\mathrm{m} / \mathrm{day}$ & 6,745 & 6,836 \\
\hline Water consumption & & & \\
\hline
\end{tabular}




\subsection{Additional Opportunities for Cost Reduction}

Beyond the process configurations considered in this report, several other opportunities could be followed to further reduce MFSP. Although outside the scope of the present TEA work, these potential strategies are briefly discussed and could be evaluated in more detail in the future.

\section{Add Value to Furans}

Both dedicated and integrated biorefineries assessed in this report aim to produce fuels via an approach centered around the production of furans through sugar dehydration as a means of obtaining reactive molecules for aldol condensation, with a ketone and further hydrotreating. The process could benefit from selling part of them directly to the market, because both furfural and HMF are products with industrial use. This is an especially interesting option in view of the high yields of furans expected from sugars in the hydrolysate stream in future scenarios; such biorefineries could afford diverting a portion of furans to this end. Alternatively, furans are also precursors to a multitude of other relevant products, as depicted in Figure 17. Such pathways, mostly catalytic ones, could give origin to compounds such as $\gamma$-valerolactone, caprolactam, and 2,5-furandicarboxylic acid (FDCA) from HMF [26] and 2-methyltetrahydrofuran (MTHF) and furfuryl alcohol from furfural [27]. In short, selling furans to the market or producing different compounds from furans would expand the biorefinery concept presented in this report to a multiproduct plant, besides the already produced hydrocarbon fuel, adipic acid, and sodium sulfate. The exact economic impact and feasibility of either approach should be assessed in future efforts.

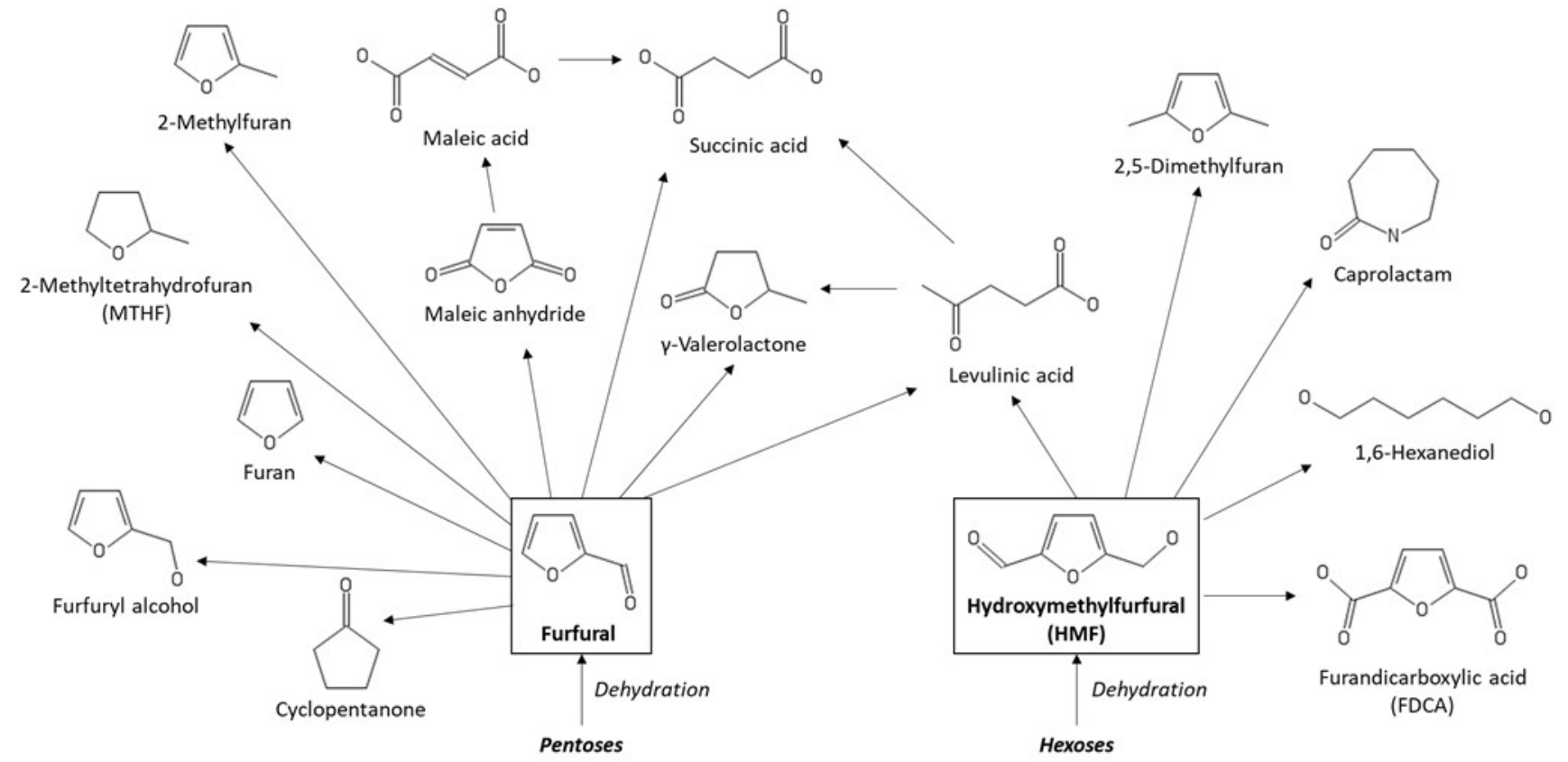

Figure 17. Pathways from furfural and HMF to products of industrial interest (based on [27] and [28])

\section{Add Value to Coproducts from BDO Dehydration}

The catalytic upgrading of BDO to MEK in Area 550 generates several byproducts, such as isobutanol (major compound) and minor fractions of 1,3-butadiene, isobutanal, and 3-buten-2-ol. The molar yield to each molecule is summarized in Table 11 (Section 3.6.2). The current sequence of distillation columns after BDO upgrading aims to recover MEK close to its azeotrope composition with water for 
further use in the aldol condensation reaction with furans in Area 500. Water and other organic compounds present in the stream leaving the BDO upgrading reactor are currently sent to WWT. Although recovering some of these compounds with the intention of selling them to market would entail additional CAPEX and OPEX, this possibility could ultimately have a positive impact on the carbon efficiency of the biorefinery, its sustainability metrics, and economic performance.

\section{Add Value to Lignin with Alternative Pathways}

As pointed out in this report, adipic acid is intended to represent one example of many other potential products from lignin. In a scenario with the deployment of multiple similar biorefineries dedicated to the production of hydrocarbon fuels, several of them would be expected to add value to lignin in different ways to be able to generate coproduct credits without oversupplying the market with a single compound. This could be achieved with a multitude of routes, either biological ones, catalytic processes, or a combination thereof [28].

\section{Concluding Remarks}

\subsection{Summary}

This report, an effort stemming from the CUBI project within the Chemical Catalysis for Bioenergy Consortium (ChemCatBio), proposes two conceptual biorefining configurations for the production of upgraded renewable hydrocarbon fuels coupled with bio-derived coproducts. The core of the biorefineries is a pathway that initiates with sugar dehydration to furans, an aldol condensation reaction with a ketone, and a final step of hydrotreating to obtain hydrocarbons in the $\mathrm{C}_{14}-\mathrm{C}_{16}$ range. A dedicated biorefinery focuses at converting all sugars in the hydrolysate stream to furans (furfural and HMF) while purchasing external MEK to carry out the final stages of fuel production. On the other hand, an integrated biorefinery produces both furans and MEK from sugars to generate the hydrocarbon fuel; MEK is obtained after upgrading of BDO synthesized through whole-slurry fermentation. In addition to biomass deconstruction to sugars and lignin valorization through adipic acid production via muconic acid fermentation, the report sets future performance targets for the full pathway dedicated to sugar upgrading to fuels.

Final results of the TEA point to an estimated MFSP of \$2.54/GGE for the dedicated biorefinery (2016\$) at a final upgraded fuel product yield of $108.4 \mathrm{GGE} /$ dry ton of biomass and an MFSP of \$2.72/GGE for the integrated plant at a fuel product yield of $61.2 \mathrm{GGE} /$ dry ton of biomass. Both results are comparable to those obtained in a previous NREL design case [1], indicating that the pathways presented herein are viable alternatives to achieve similar fuel cost targets through purely catalytic upgrading of sugars. The inclusion of adipic acid as a high-value, lignin-derived coproduct in the plants at a yield of 284 and $276 \mathrm{lb} /$ dry ton of biomass, respectively, can significantly contribute toward reducing MFSP, corresponding to credits of negative $\$ 1.23 / \mathrm{GGE}$ and $\$ 2.16 / \mathrm{GGE}$, respectively. A sensitivity analysis was also critical to pinpoint the major cost drivers of the biorefineries. The main factor for either biorefining setup is adipic acid price, which could lead to large swings in MFSP depending on its market price. The yield to furans in sugar dehydration is also a highly impactful parameter. For the dedicated plant specifically, the price at which MEK is purchased could also lead to significantly different MFSP results.

Finally, the report also presents key sustainability metric indicators for the modeled biorefining configurations, which are suggestive of the environmental performance of the systems. For the dedicated plant, these metrics were estimated at $48 \%$ carbon recovery in the form of hydrocarbon 
fuels, $5.2 \mathrm{kWh} / \mathrm{GGE}$ net power import, $36 \mathrm{MJ} / \mathrm{GGE}$ natural gas consumption, and $7.4 \mathrm{gal} / \mathrm{GGE}$ net water demands for the biorefinery. For the integrated biorefinery, the same metrics were estimated at $29 \%$ carbon recovery as fuels, $6.4 \mathrm{kWh} / \mathrm{GGE}$ power import, $96 \mathrm{MJ} / \mathrm{GGE}$ natural gas consumption, and $13.4 \mathrm{gal} / \mathrm{GGE}$ net water demand.

\subsection{Future Work}

Moving forward, certain possibilities for further development and assessment could ultimately achieve cost goals and reduce uncertainty in key areas for the modeled processes evaluated here:

- Achieve future high-yield targets of furans from sugars: Among the parameters directly tunable under CUBI, achieving (or maintaining) a high yield to furans via sugar dehydration stands among the top three priorities identified during the sensitivity analyses in Section 5.2.

- Improve catalyst performance for BDO upgrading to MEK: The unwanted conversion of $\mathrm{BDO}$ to minor coproducts during catalytic upgrading to MEK has several detrimental effects to the integrated biorefining configuration assessed in this report, namely the loss of carbon from $\mathrm{BDO}$ to other nonreactive compounds and the need for a sequence of distillation columns to effectively purify MEK for further use. A reduction in the number of coproducts would be highly beneficial to achieve lower MFSPs. This is also a parameter that could be modulated under CUBI.

- Achieve future lignin deconstruction, bioconversion, and upgrading targets: The assessment clearly shows the dependence of achieving low MFSPs on the commercialization of a high-value coproduct in the form of adipic acid from lignin. For the assumptions to be valid, the targets considered in the TEA for lignin deconstruction/conversion/upgrading should receive special attention from the associated experimental development team.

- Assess (in detail) the impact of carrying out fermentations using clarified hydrolysate: A preliminary assessment of this strategy was presented in Section 5.2.4. Further TEA work related to this fermentation approach could be conducted to examine in detail its benefits and disadvantage.

- Assess options for product portfolio diversification: In an integrated, multiproduct biorefinery, alternative options for diversifying product portfolio and improving the robustness of the plant could be possible. These may pass through adding value to furans, to coproducts obtained during BDO dehydration, and to lignin through different conversion pathways, as detailed in Section 5.4. 


\section{References}

1. Davis, R., N. Grundl, L. Tao, M. J. Biddy, E. C. D. Tan, G. T. Beckham, D. Humbird, D. N. Thompson, and M. S. Toni. 2018. Process Design and Economics for the Conversion of Lignocellulosic Biomass to Hydrocarbon Fuels and Coproducts: 2018 Biochemical Design Case Update. Golden, CO: National Renewable Energy Laboratory. NREL/TP-5100-71949. https://www.nrel.gov/docs/fy19osti/71949.pdf

2. Humbird, D., R. Davis, L. Tao, C. Kinchin, D. Hsu, A. Aden, P. Schoen, et al. 2011. Process Design and Economics for Biochemical Conversion of Lignocellulosic Biomass to Ethanol: DiluteAcid Pretreatment and Enzymatic Hydrolysis of Corn Stover. Golden, CO: National Renewable Energy Laboratory. NREL/TP-5100-47764. https://www.nrel.gov/docs/fy11osti/47764.pdf

3. Davis, R., L. Tao, E. C. D. Tan, M. J. Biddy, G. T. Beckham, C. Scarlata, J. Jacobson, et al. 2013. Process Design and Economics for the Conversion of Lignocellulosic Biomass to Hydrocarbons: Dilute-Acid and Enzymatic Deconstruction of Biomass to Sugars and Biological Conversion of Sugars to Hydrocarbons. Golden, CO: National Renewable Energy Laboratory. NREL/TP-510060223. https://www.nrel.gov/docs/fy14osti/60223.pdf

4. Davis, R., L. Tao, C. Scarlata, E. C. D. Tan, J. Ross, L. Lukas, and D. Sexton. 2015. Process Design and Economics for the Conversion of Lignocellulosic Biomass to Hydrocarbons: DiluteAcid and Enzymatic Deconstruction of Biomass to Sugars and Catalytic Conversion of Sugars to Hydrocarbons. Golden, CO: National Renewable Energy Laboratory. NREL/TP-5100-62498. https://www.nrel.gov/docs/fy15osti/62498.pdf

5. Dysert, L.R., et al. 2016. Cost estimate classification system - As applied in engineering, procurement, and construction for the process industries. Morgantown, WV: AACE International. 18R-97.

6. Cran, J. 1981. "Improved factored method gives better preliminary cost estimates." Chemical Engineering 88 (7): 65-79.

7. Aden, A., M. Ruth, K. Ibsen, J. Jechura, K. Neeves, J. Sheehan, B. Wallace, L. Montague, A. Slayton, and J. Lukas. 2002. Lignocellulosic Biomass to Ethanol Process Design and Economics Utilizing Co-Current Dilute Acid Prehydrolysis and Enzymatic Hydrolysis for Corn Stover. Golden, CO: National Renewable Energy Laboratory. NREL/TP-510-32438. https://www.nrel.gov/docs/fy02osti/32438.pdf

8. U.S. Department of Energy Hydrogen Analysis Resource Center. 2012. "Lower and higher heating values of hydrogen and fuels." https://h2tools.org/hyarc/calculator-tools/lower-and-higher-heatingvalues-fuels

9. Perry, R.H. and D.W. Green. 1997. Perry's Chemical Engineers' Handbook, 7th Edition. New York, NY: McGraw-Hill.

10. Bowen, E., S.C. Kennedy, and K. Miranda. 2010. Ethanol from Sugar Beets: A Process and Economic Analysis. Worcester, MA: Worcester Polytechnic Institute.

11. Fagerson, I.S. 1969. "Thermal degradation of carbohydrates; a review." Journal of Agricultural and Food Chemistry 17 (4): 747-750.

12. Zheng, Q., et al. 2015. "Conversion of 2,3-butanediol to butenes over bifunctional catalysts in a single reactor." Journal of Catalysis 330: 222-237. 
13. Dagle, V. and S. Phillips. 2020. Personal communication.

14. Vardon, D.R., et al. 2016. "cis, cis-Muconic acid: separation and catalysis to bio-adipic acid for nylon-6, 6 polymerization." Green Chemistry 18 (11): 3397-3413.

15. Li, Q., et al. 2010. "One step recovery of succinic acid from fermentation broths by crystallization." Separation and Purification Technology 72 (3): 294-300.

16. Urbanus, J., et al. 2012. "Intensified crystallization in complex media: Heuristics for crystallization of platform chemicals." Chemical Engineering Science 77: 18-25.

17. U.S. Department of Energy Office of Energy Efficiency and Renewable Energy. 2016. Bioenergy Technologies Office Multi Year Program Plan. Washington, D.C.: EERE. DOE/EE-1385. https://www.energy.gov/sites/default/files/2016/07/f33/mypp_march2016.pdf

18. Chemical Engineering Magazine. 2011. Chemical Engineering Plant Cost Index.

19. U.S. Bureau of Labor Statistics. 2009. "National Employment, Hours, and Earnings Catalog, Industry: Chemicals and Allied Products, 1980-2009." http://data.bls.gov/cgi-bin/srgate.

20. U.S. Energy Information Administration. 2020. "Natural Gas Prices." https://www.eia.gov/dnav/ng/ng_pri_sum_dcu_nus_m.htm

21. U.S. Department of Agriculture. 2018. "Table 7-U.S. wholesale list price for glucose syrup, Midwest markets, monthly, quarterly, and by calendar and fiscal year." U.S. Department of Agriculture Economic Research Service - Sugar and Sweeteners Yearbook Tables.

22. Dillich, S., T. Ramsden, and M. Melina. 2012. U.S. Department of Energy Hydrogen and Fuel Cells Program Record. https://www.hydrogen.energy.gov/pdfs/12024_h2_production_cost_natural_gas.pdf.

23. Steinwinder, T., E. Gill, and M. Gerhardt. 2011. Process Design of Wastewater Treatment for the NREL Cellulosic Ethanol Model. Golden, CO: National Renewable Energy Laboratory. NREL/SR5100-51838. https://www.nrel.gov/docs/fy1 losti/51838.pdf

24. Peters, M.S. and K.D. Timmerhaus. 2003. Plant design and economics for chemical engineers. New York, NY: McGraw-Hill.

25. SRI Consulting. 2008. "U.S. Producer Price Indexes - Chemicals and Allied Products/Industrial Inorganic Chemicals Index." In Chemical Economics Handbook.

26. Bhaumik, P. and P.L. Dhepe. 2016. "Solid acid catalyzed synthesis of furans from carbohydrates." Catalysis Reviews 58 (1): 36-112.

27. Kabbour, M. and R. Luque. 2020. "Chapter 10 - Furfural as a platform chemical: From production to applications." In Biomass, Biofuels, Biochemicals. Edited by S. Saravanamurugan et al., 283297. Elsevier.

28. Linger, J.G., et al. 2014. "Lignin valorization through integrated biological funneling and chemical catalysis." Proceedings of the National Academy of Sciences 111 (33): 12013-12018. 


\section{Appendix A. Individual Equipment Costs Summary}

The following tables show abbreviated specifications, purchased cost, and installed cost for each piece of equipment in this process design. Although each piece of equipment has its own line, many were quoted as part of a package, so their scaling calculations are not shown. NREL would like to acknowledge the subcontractors and equipment vendors who assisted us with cost estimates over recent years as were utilized for this report. 
Dedicated Biorefinery

\begin{tabular}{|c|c|c|c|c|c|c|c|c|c|c|c|c|c|c|c|c|c|}
\hline A200: Pretreatment & & nt List & & & & \multicolumn{12}{|c|}{ Scaled Installed costs } \\
\hline EQUIPMENT TITLE & DESCRIPTION & HP & MaterlaL & 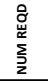 & $\$$ & 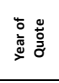 & $\begin{array}{c}\text { Purch cost in } \\
\text { Base } \mathrm{Yr}\end{array}$ & Scaling Variable & 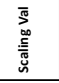 & $\frac{2}{5}$ & 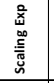 & 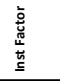 & $\begin{array}{l}\text { 贾 } \\
\frac{3}{2}\end{array}$ & 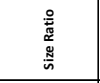 & $\begin{array}{l}\text { Scaled Purch } \\
\text { cost }\end{array}$ & $\begin{array}{l}\text { Purch cost in } \\
\text { Proj year }\end{array}$ & $\begin{array}{c}\text { Inst Cost in Proj } \\
\text { vear }\end{array}$ \\
\hline 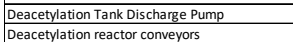 & 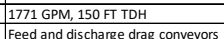 & $\begin{array}{l}100 \\
40 \mathrm{hp}\end{array}$ & $\begin{array}{ll}31655 \\
553316\end{array}$ & $\frac{1}{3}$ & $\begin{array}{l}\frac{52,500}{5510,000} \\
\end{array}$ & 2009 & $\begin{array}{c}\frac{\$ 22,500}{\$ 10,000} \\
\end{array}$ & $\begin{array}{l}\text { stm.a200.211a } \\
\text { stma.200.211a }\end{array}$ & $\begin{array}{l}402194 \\
227767 \\
\end{array}$ & $\mathrm{~kg} / \mathrm{hr}$ & $\begin{array}{ll}0.80 \\
0.080\end{array}$ & & 283668 28368. & $\frac{0.71}{1.02}$ & $\begin{aligned} \$ 17,017 \\
\$ 336,178\end{aligned}$ & $\begin{array}{c}\$ 17,663 \\
321,008 \\
\end{array}$ & 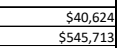 \\
\hline 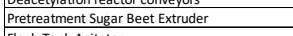 & 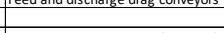 & 年 & & 1 & $\begin{array}{l}\$ 5,424,0,000 \\
52,00\end{array}$ & 2010 & $\begin{aligned} 55,424,000 \\
\end{aligned}$ & 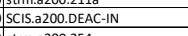 & $\frac{25600}{38600}$ & 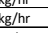 & 1.00 & & $\begin{array}{ll}2050003 \\
70483 \\
\end{array}$ & $\frac{1.83}{1.83}$ & $\begin{array}{ll}59,904,187 \\
50,187\end{array}$ & 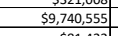 & $\frac{\frac{5445,13}{59,740,555}}{\$ 102,19}$ \\
\hline $\begin{array}{l}\text { Fash hankn AAtitator } \\
\text { Ammonia Adition Tank Agitator }\end{array}$ & Sidd-mounted, $3 \times 75$ hp. $(17 \mathrm{oW})$ & $\frac{170 \mathrm{~kW}}{10 \mathrm{hp}}$ & $\frac{316 \mathrm{Ls}}{\mathrm{ss}}$ & $\frac{3}{1}$ & $\begin{array}{l}\$ \$ 0,000 \\
\$ 21,900 \\
\end{array}$ & 2009 & $\begin{array}{r}\$ 9,0,00 \\
\$ 2,1900 \\
\end{array}$ & 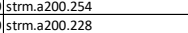 & 2528911 & kghr & $\frac{0.50}{0.50}$ & & 2921744 & 0.766 & $\begin{array}{l}578,455 \\
516419 \\
\end{array}$ & $\begin{array}{l}\$ 81,432 \\
17042\end{array}$ & $\begin{array}{l}\$ 122,148 \\
\$ 22,563 \\
\end{array}$ \\
\hline 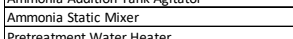 & 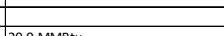 & ton & 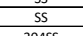 & $\frac{1}{1}$ & $\begin{array}{ll}35,000 \\
5,000 \\
5\end{array}$ & 2009 & $\frac{525,00}{55,000}$ & 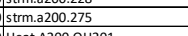 & $\frac{453078}{157478}$ & 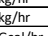 & $\frac{0.50}{0.50}$ & & 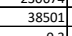 & $\frac{0.34}{0.24}$ & 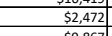 & 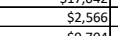 & $\frac{\frac{322.56}{52.56}}{5.238}$ \\
\hline Milling Equipment Fenter & 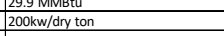 & & & $\frac{1}{8}$ & 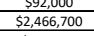 & $\frac{2010}{2013}$ & 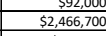 & 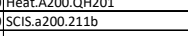 & 62942 & $\begin{array}{ccc}c a / h r \\
\mathrm{~kg} / \mathrm{hr}\end{array}$ & $\frac{0.100}{0.60}$ & & 57306 & $\frac{0.91}{0.91}$ & $\$ \$ \$ 19,73,6000$ & 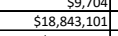 & $\frac{\$ 21,348}{\$ 28,246,651}$ \\
\hline 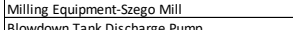 & & & & 11 & $\frac{5578,000}{552,65}$ & 2013 & $\begin{array}{l}\$ 578,000 \\
\$ \$ 25,653\end{array}$ & 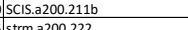 & $\frac{62942}{202027}-12010$ & kg/hr & 0.60 & $\frac{1.4}{23}$ & 57306 & 0.91 & $\$ 6,358,000$ & $\$ 6,071,089$ & $58,499,524$, \\
\hline 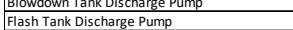 & 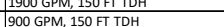 & $\frac{125}{75}$ & $\frac{31655}{31655}$ & & $\frac{525,635}{530,000}$ & $\frac{2010}{2009}$ & $\frac{\$ 25,635}{\$ 30,000}$ & $\begin{array}{ll}\text { strtm.a2000.222 } \\
\text { stma.2200.254 }\end{array}$ & $\frac{292407}{204390}$ & kghr & 0.80 & & $\frac{193160}{192174}$ & $\frac{0.66}{0.94}$ & $\frac{518,398}{528,557}$ & $\frac{588,044}{529,640}$ & $\frac{514,617}{\$ 68,172}$ \\
\hline Hydrolyzate Pump Purge Pump & 1771 GPM, 150 FT TDH & 100 & 31655 & 1 & 522,500 & 2009 & $\begin{aligned} \frac{350,000}{\$ 22,500} & -1\end{aligned}$ & strm.2a200.254 & 402194 & gg/hr & $\frac{0.80}{0.80}$ & $\frac{2.3}{2.3}$ & 230674 & 0.57 & $\frac{214,422}{51422}, 0$ & $\begin{array}{l}\$ \$ 9,6404 \\
14,969\end{array}$ & $\frac{\$ 68,172}{\$ 34,430}-100$ \\
\hline $\begin{array}{c}\mathrm{S} / \mathrm{L} \text { split Discharge Pump to WWT } \\
\end{array}$ & $900 \mathrm{GPM}, 150$ FT TDH & 75 & 31655 & 1 & $\$ 30,000$ & 2009 & $\$ 30,000$ & strm.2200.4 & 204390 & $\mathrm{~g} / \mathrm{hr}$ & 0.80 & 2.3 .3 & 193160 & & 528,674 & & 568,452 \\
\hline $\begin{array}{l}\text { Flash Tank } \\
\text { Ammoni Addition Tank }\end{array}$ & 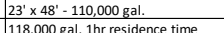 & & $\frac{55316}{55304}$ & $\frac{1}{1}$ & $\begin{array}{l}\$ 511,000 \\
\$ \$ 33,000\end{array}$ & $\frac{2009}{2009}$ & $\begin{array}{l}5511,000 \\
\$ 236,000\end{array}$ & 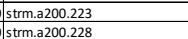 & $\begin{array}{ll}264116 \\
4401099 \\
\end{array}$ & $\mathrm{~kg} / \mathrm{hr}$ & \begin{tabular}{c|c|c|}
0.70 \\
0.70 \\
\end{tabular} & & $\begin{array}{lll}193160 \\
232607\end{array}$ & $\frac{0.73}{0.56}$ & 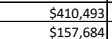 & 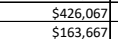 & $\begin{array}{l}5852,133 \\
537,34\end{array}$ \\
\hline & $118,000 \mathrm{gal}, 1,1 \mathrm{nh}$ residence titu & & & & & & & & & & & & & Area 200 Totals & $\$ 37,114,424$ & $\$ 35,786,358$ & $\begin{array}{r}\$ 387,34,34 \\
\$ 48,55,831 \\
\end{array}$ \\
\hline
\end{tabular}

\begin{tabular}{|c|c|c|c|c|c|c|c|c|c|c|c|c|c|c|c|c|c|}
\hline A300: Hydrolysis and Fermentation & & nt List & & & & & & & & & IInstall| & Costs & & & & & \\
\hline EQUIPMENT TITLE & DESCRIPTION & HP & MATERIAL & 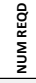 & $\$$ & 递 & $\begin{array}{c}\text { Purch cost in } \\
\text { Base Yr }\end{array}$ & Scaling Variable & 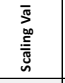 & 常 & 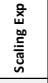 & 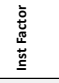 & 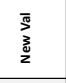 & 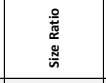 & $\begin{array}{l}\text { Scaled Purch } \\
\text { cost }\end{array}$ & $\begin{array}{l}\text { Purch coss in } \\
\text { Proj year }\end{array}$ & $\begin{array}{c}\text { Inst cost in proj } \\
\text { vear }\end{array}$ \\
\hline $\begin{array}{l}\text { Batch nnzymatic Hydrolysis } \\
\text { Hydrolyzate Cooler }\end{array}$ & Plate \& Frame $32.5 \mathrm{MMBt} / \mathrm{hr}$ & & 553044 & 1 & 585,000 & 2010 & 585,000 & heat.A300.EH.QC $\mathrm{CCO1}$ & & Gcal/hr & 0.70 & & & 0.80 & 572,529 & $\$ 71,331$ & $\$ 156,928$ \\
\hline $\begin{array}{l}\text { Enzyme Hdrorlysate } \\
\text { Saccharification Tank }\end{array}$ & 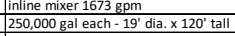 & $100 \mathrm{hp}$ & $\frac{53316}{30455}$ & $\frac{1}{8}$ & $\begin{array}{l}\$ 199,000 \\
\$ 3,840,000\end{array}$ & $\frac{2009}{2009}$ & $\begin{aligned} & \$ 0 \\
\$ 3,840,000 & \end{aligned}$ & & 379938 & & $\begin{array}{c}0.50 \\
0.70 \\
\end{array}$ & & & 0.00 & & $\begin{aligned} 50 \\
52,672,192 \\
\end{aligned}$ & \\
\hline $\begin{array}{l}\text { Sacchanfification Transfer Pump } \\
\text { SEmymatc }\end{array}$ & 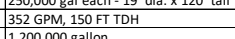 & 20 & 31655 & 5 & $\begin{array}{ll}\$ 3,344,000 \\
547,200 \\
\end{array}$ & 2009 & 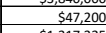 & 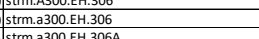 & 4217776 & kg/hr & $\begin{array}{c}0.80 \\
0.80\end{array}$ & & $\begin{array}{r}23349 \\
238249 \\
\end{array}$ & 0.56 & $\begin{aligned} \$ 2,54,506 \\
29,888 \\
\end{aligned}$ & $\begin{aligned} 52,62,1,124 \\
31,022 \\
\end{aligned}$ & $\begin{array}{r}\$ 5,344,385 \\
\$ 71,351 \\
\$ 17,941\end{array}$ \\
\hline 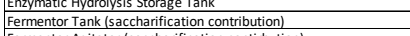 & , 200,000 gallon & & $\frac{36055}{30455}$ & $\frac{1}{12}$ & $\frac{\$ 1,37,7325}{\$ 10,128,000}$ & $\frac{2011}{2009}$ & $\begin{array}{r}\$ 1,317,325 \\
10,0128,000 \\
55,50\end{array}$ & strm.a300.EH.306A & $\frac{328984}{12}$ & $\begin{array}{ll}\mid \mathrm{kg} / \mathrm{hr} \\
\text { ea }\end{array}$ & $\begin{array}{r}0.70 \\
1 \\
1\end{array}$ & $\begin{array}{r}1.8 \\
1.50 \\
\end{array}$ & $\begin{array}{r}238249 \\
7.8 \\
78\end{array}$ & $\begin{array}{l}0.72 \\
0.65 \\
.75\end{array}$ & $\begin{array}{l}\$ 1,050,976 \\
\$ 6,23,653 \\
\varsigma 1,031\end{array}$ & 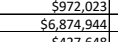 & $\begin{aligned} \$, 749,641 \\
\$ 10,312,415 \\
561,01\end{aligned}$ \\
\hline 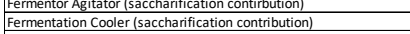 & Plate \& \& frame & $30 \mathrm{hp}$ & $\frac{53504}{3045}$ & & $\begin{aligned} \$ 52,500 \\
\$ 86,928\end{aligned}$ & $\frac{2009}{2009}$ & $\begin{aligned} 552,500 \\
586,928 \\
\end{aligned}$ & & & ea & & & & $\frac{7.85}{0.65}$ & $\begin{aligned} 5426,016 \\
556,500 \\
\end{aligned}$ & $\begin{aligned} 5427,648 \\
559,007 \\
\end{aligned}$ & $\begin{array}{ll}5541,471 \\
5129,816 \\
\end{array}$ \\
\hline Fermentation Recirc/Transfer Pump /saccharification & 340 GPM, 150 FT & & 31655 & 5 & 547,200 & 2009 & 547,200 & & & ea & 0.8 & 2.36 & $1.8-8-3$ & 0.65 & $\begin{array}{c}50,005 \\
53,605 \\
\end{array}$ & $\frac{535,000}{534,880}$ & $\frac{5199,816}{58,223}$ \\
\hline $\begin{array}{l}\text { Vaccuum filter press (VFP) } \\
\text { SurarConcontratiof }\end{array}$ & (4) $170 \mathrm{~m} 2$ Horizontal Belt Filters & 660 hp ea & $\begin{array}{l}30455 \\
30055 \\
3045\end{array}$ & 7 & $\$ 2,152,500$ & 2013 & 56370000 & NS.SUG & & & 1 & 1.7. & & 1.00 & $\begin{array}{l}\frac{\$ \$ 15,067,500}{\$ 830003} \\
830\end{array}$ & $\frac{\$ 14,387,563}{\$ 801103}$ & 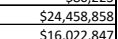 \\
\hline Concentrated Suguar Storage Tank & 5,500 gallons -20 min residence time & $20 \mathrm{hp}$ & $\frac{3045}{55}$ & 1 & $\frac{50,317,000}{\$ 168,000}$ & $\frac{2013}{2011}$ & $\begin{array}{ll}\frac{50,317,0,00}{\$ 168,000} \\
\end{array}$ & STRM.AS00.FURANS.S16 & 76712 & $\mathrm{~kg} / \mathrm{hr}$ & 0.70 & 1.8 & 361769 & 4.72 & $\frac{38,390,034}{\$ 497,516}$ & $\begin{aligned} 380101,435 \\
\$ 460,140 \\
\end{aligned}$ & $\frac{56022,847}{5828,253}$ \\
\hline & & & & & & & & & & & & & & Area 300 Totals & $\$ 34,809,086$ & $\$ 34,002,173$ & $\$ 59,796,188$ \\
\hline
\end{tabular}

\begin{tabular}{|c|c|c|c|c|c|c|c|c|c|c|c|c|c|c|c|c|c|}
\hline A400: Enzyme Production & & ent List & & & & & & & & & IInstal & Costs & & & & & \\
\hline EQUPMENT TITLE & DESCRIPTION & HР & MATERIAL & 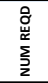 & $\$$ & 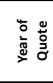 & $\begin{array}{c}\text { Purch cost in } \\
\text { Base } \mathrm{Yr}\end{array}$ & Scaling Variable & 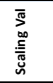 & $\frac{2}{5}$ & 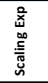 & 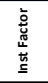 & $\begin{array}{l}\text { 嵒 } \\
\frac{3}{2}\end{array}$ & 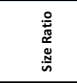 & $\begin{array}{l}\text { Scaled Purch } \\
\text { cost }\end{array}$ & $\begin{array}{l}\text { Purch cost in } \\
\text { Proj year }\end{array}$ & $\begin{array}{l}\text { Inst Cost in Proj } \\
\text { year }\end{array}$ \\
\hline 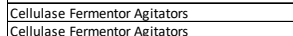 & & 800.0 & $\frac{55316}{5316}$ & & $\frac{5580,000}{6300}$ & 2009 & $\begin{array}{l}\$ 580,000 \\
58020\end{array}$ & 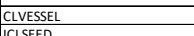 & & ea & 1.00 & & & 5.00 & $\$ 2,900,000$ & $\$ 3,010,021$ & $\$ 4,515,032$ \\
\hline 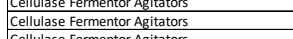 & & $\frac{0.75 \mathrm{p}}{8 \mathrm{hp}}$ & 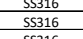 & & $\begin{array}{ll}53,400 \\
51,000 \\
50\end{array}$ & $\frac{2009}{2009}$ & $\frac{\$ 3,400}{511,000}$ & 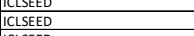 & & ea $\frac{\text { ea }}{e a}$ & $\begin{array}{c}1.00 \\
1.00 \\
\end{array}$ & & & $\frac{7.00}{4.00}$ & $\frac{513,060}{54,000}$ & $\begin{array}{ccc}514,199 \\
44,669\end{array}$ & $\begin{array}{c}52,2,98 \\
568,504 \\
\end{array}$ \\
\hline 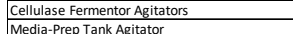 & & $80 \mathrm{hp}$ & $\begin{array}{ll}553316 \\
28285\end{array}$ & 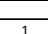 & $\frac{563,000}{58,50}$ & 2009 & $\frac{563,000}{58,500}$ & & & 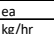 & 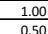 & & & $\begin{array}{c}4.00 \\
0.00 \\
\end{array}$ & 5252,000 & 5261,5600 & $\begin{array}{ccc}5392,341 \\
50\end{array}$ \\
\hline 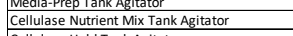 & & $\frac{7.5 \mathrm{hp}}{3 \mathrm{hp}}$ & $\frac{A 285 \mathrm{C}}{\mathrm{CS}}$ & $\frac{1}{1}$ & $\begin{array}{c}58,500 \\
54,800 \\
\end{array}$ & 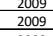 & $\begin{aligned} 5,5,500 \\
54,800 \\
\end{aligned}$ & $\begin{array}{l}\text { sitm.240.042a } \\
\text { strm.a400.416 }\end{array}$ & $\frac{124}{17}$ & kg/hr & $\begin{array}{l}0.50 \\
0.50 \\
\end{array}$ & & & $\frac{0.00}{0.70}$ & $\begin{aligned} 54,030 \\
50\end{aligned}$ & $\begin{aligned} 54,182 \\
\end{aligned}$ & 56,502 \\
\hline 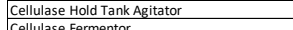 & & $10 \mathrm{hp}$ & $\begin{array}{c}55316 \\
5316\end{array}$ & 1 & $\begin{array}{ll}526,900 \\
50500\end{array}$ & 2009 & $\begin{array}{lll}526,900 \\
50,000\end{array}$ & $\begin{array}{lll}s t m .422 \\
\text { str. }\end{array}$ & 1093 & $\mathrm{~kg} / / \mathrm{rr}$ & 0.50 & & 757. & 0.69 & 522,395 & 523,244 & 534,866 \\
\hline $\begin{array}{l}\text { Cellulale Fermentor } \\
1 \text { is Cellulase Seed Fermentor }\end{array}$ & 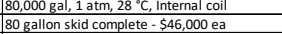 & 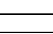 & $\frac{553316}{3045}$ & 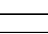 & $\frac{\frac{5400,500}{546,000}}{-1}$ & $\frac{2009}{2009}$ & $\begin{array}{c}5440,500 \\
54,000\end{array}$ & $\begin{array}{l}\text { CLVESSSEL } \\
\text { ICISEED }\end{array}$ & & ea & $\frac{1.00}{1.00}$ & & & $\frac{5.00}{4.00}$ & $\begin{array}{llll}\$ 2,002,500 \\
5184,000\end{array}$ & 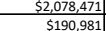 & $\$ \frac{\$ 4,156,943}{5347365}$ \\
\hline $\begin{array}{l}2 \text { 2nd Cellulase Seed Fermentor } \\
2 \text { dallse }\end{array}$ & 800 gallon skid complete - 557,500 ea & & 30455 & & 557,500 & 2009 & 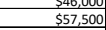 & ICLSEED & & ea & $\begin{array}{lll}1.00 \\
1.00\end{array}$ & & & 4.00 & 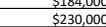 & $\begin{array}{ll}199,984 \\
\$ 238,726\end{array}$ & $\begin{array}{lll}5344,165, \\
5429,706\end{array}$ \\
\hline 3 rd Cellulase Seed Fermentor & 8,000 gallon skid complete $-\$ 95,400$ ea & & 30455 & & 595,400 & 2009 & $\$ 95,400$ & $\frac{1 \text { CLSEED }}{\text { ICLSED }}$ & & ea & 1.00 & & & 4.00 & $\$ 381,600$ & $\$ 3396,077$ & $\begin{array}{lll}5442,909 \\
5712,939\end{array}$ \\
\hline $\begin{array}{l}\text { Cellulase Fermentation Cooler } \\
\text { Media Prep Tank Cooler }\end{array}$ & Cooling coili included with Cellulase Fermentete & & 30455 & & $\begin{array}{l}\text { INCLUDED } \\
\text { INCLDED }\end{array}$ & & & & & & & & & & & & \\
\hline $\begin{array}{l}\text { Medidi Prep Tank coler } \\
\text { Eermenter Air Compressor Package }\end{array}$ & 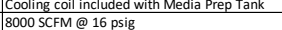 & & $\frac{3045}{\mathrm{cs}}$ & $\frac{1}{2}$ & $\begin{array}{l}\text { INCLLUED } \\
\$ 350,000\end{array}$ & 2009 & $\$ 350,000$ & strm.a400.450 & $33168 \mathrm{~s}>\mathrm{C}$ & $\mathrm{kg} / \mathrm{hr}$ & 0.60 & & 17839 & 0.54 & & $\$ 250,3955$ & \\
\hline 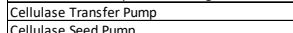 & $59 \mathrm{gpm}, 100 \mathrm{FT}, \mathrm{TOH}$ SIZE $2 \times 1-10 \mathrm{C}$ & 3 & 31655 & 1 & $\begin{array}{l}57,357 \\
5,307 \\
\end{array}$ & 2010 & $\frac{507,037}{57,357}$ & strm. .4000 .420 & 13399 & eg/hr & 0.80 & & 7575 & 0.57 & $\frac{1044,64}{54,62}$ & 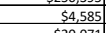 & $\begin{array}{l}540,035 \\
510,545\end{array}$ \\
\hline $\begin{array}{l}\text { Selinases seed Pump } \\
\text { Nedia Pump }\end{array}$ & 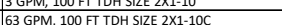 & $\frac{2}{3}$ & $\frac{31655}{31655}$ & $\frac{4}{1}$ & $\frac{529,972}{57,57}$ & $\frac{2010}{2010}$ & $\frac{529,972}{5,357}$ & $\begin{array}{l}\text { strtm.a4000.409 } \\
\text { stm.ana0 }\end{array}$ & $\frac{68}{14307}$ & $\mathrm{~kg} / \mathrm{g} / \mathrm{r}$ & 0.80 & & 4211 & $\frac{0.62}{0.00}$ & $\frac{520,408}{50}$ & $\frac{520,071}{50}$ & $\frac{546,163}{50}$ \\
\hline Cellulase Nutrient Transfer Pump & Gear Pump 2 GPM, 100 FT & 1 & 31655 & 1 & 51,500 & 2009 & $\$ 1,500$ & strm.a400.416 & 45 & $\mathrm{~kg} / \mathrm{hr}$ & 0.80 & & 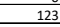 & 0.27 & $\frac{\$ 16}{\$ 526}$ & 5546 & $\begin{array}{ll}51,257 \\
\end{array}$ \\
\hline Cellulase Feed Pump & 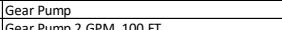 & 1 & 31655 & 1 & $\$ 5,700$ & 2009 & $\$ 5,700$ & strm. .400 .422 & 1816 & $\mathrm{~kg} / \mathrm{hr}$ & 0.80 & & & 0.42 & $\$ 2,831$ & $\$ 2,938$ & 56,758 \\
\hline $\begin{array}{l}\text { Anti-foam Pump } \\
\text { SO2 Storage Tank }\end{array}$ & 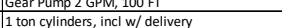 & & $\frac{31655}{55304}$ & $\frac{1}{1}$ & $\begin{array}{l}51,1500 \\
50 \\
\end{array}$ & & & & & & 0.80 & & & & & & \\
\hline & 20,000 gallon, incl. coil & & 30455 & 1 & $\$ 176,000$ & 2009 & $\$ 176,0000$ & strm.a400.402a & 122. & $\mathrm{kg} / \mathrm{hr}$ & 0.70 & & & 0.00 & & 500 & $s_{0} \mid$ \\
\hline Cellulase Nutrient Mix Tank & HDPE, 8, , ,000 gal & & HDPE & & $\$ 9,000$ & 2010 & 59,000 & stm.a400.416 & $\frac{22}{22}+20$ & kg/hr & 0.70 & & & 0.55 & $\$ 5,903$ & $55,806 \mathrm{f}$ & 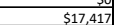 \\
\hline Cellulase Hold Tank & 80,000 gal & & 30455 & 1 & 5248,070 & 2009 & $\$ 248,070$ & strm.a400.422 & 1093 & $\mathrm{~kg} / \mathrm{hr}$ & 0.70 & & 7575 & 0.69 & $\$ 191,920$ & $\begin{array}{l}5199,201 \\
5\end{array}$ & 5358,562 \\
\hline & & & & & & & & & & & & & & Area 4000 To & $\$ 6,502,812$ & $\$ 6,747,831 \mid$ & $\$ 11,526,082$ \\
\hline
\end{tabular}




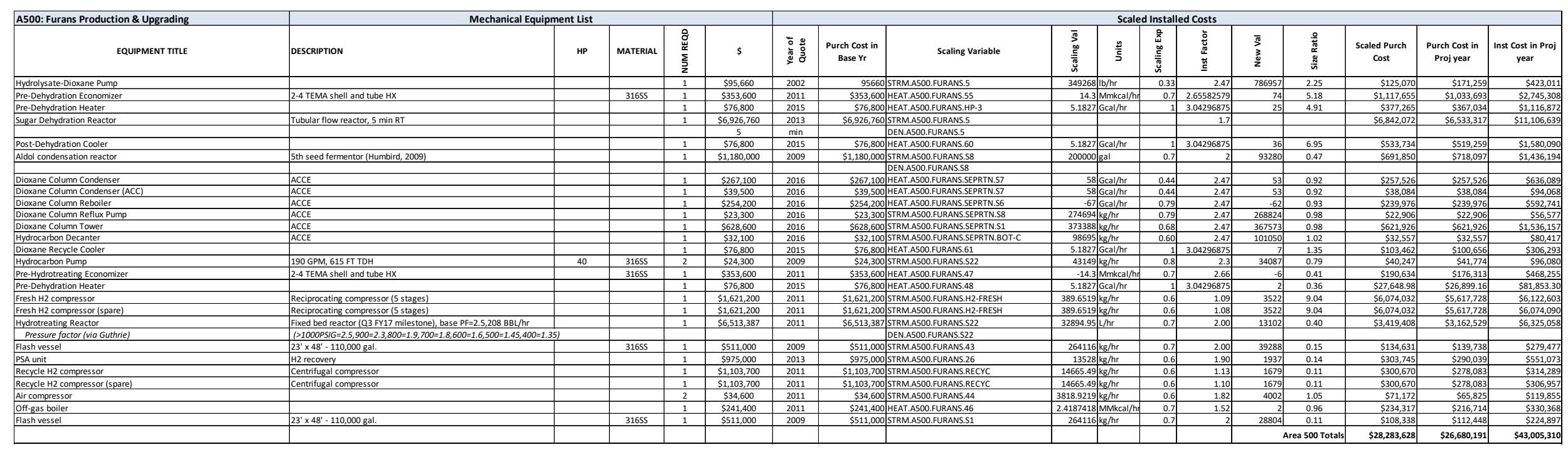

\begin{tabular}{|c|c|c|c|c|c|c|c|c|c|c|c|c|c|c|c|c|c|}
\hline A600: WWT & Mechanical Equipment List & & & & & \multicolumn{12}{|c|}{ Scaled Installed Costs } \\
\hline EQUIPMENT TITLE & DESCRIPTION & HP & MATERIAL & 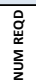 & \$ & 产 & $\begin{array}{c}\text { Purch cost in } \\
\text { Base } \mathrm{Yr}\end{array}$ & Scaling Variable & 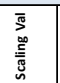 & $\frac{x^{2}}{5}$ & 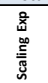 & 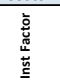 & $\begin{array}{l}\frac{\pi}{3} \\
3 \\
\frac{3}{2}\end{array}$ & 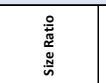 & $\begin{array}{l}\text { Scaled Purch } \\
\text { Cost }\end{array}$ & $\begin{array}{l}\text { Purch cost in } \\
\text { Proj year }\end{array}$ & $\begin{array}{c}\text { Inst cost in Proj } \\
\text { year }\end{array}$ \\
\hline \begin{tabular}{|l} 
Aeration Basin \\
Pruton
\end{tabular} & $\begin{array}{l}\text { Concrete and steel, not installed cost } \\
\text { S52 }\end{array}$ & & $\begin{array}{l}\text { Concrete } \\
\text { cs }\end{array}$ & & $\$ 4,804,854$ & 2012 & $54,804,854$ & Hydraulic flow & 2.7 & MGD & 0.60 & 2. & 1. & 0.61 & $\$ 3,578,308$ & $\$ 3,315,719$ & $56,863,538$ \\
\hline \begin{tabular}{|l|l|l} 
Pump-Centrifugal, Aeration Basin Feed \\
Aeration Grid
\end{tabular} & \begin{tabular}{|l|}
852 gpm ea \\
Ful flora aeration grid
\end{tabular} & $45 \mathrm{hp}$ & cs & $\frac{4}{1}$ & $\begin{aligned} 564,800 \\
5250000\end{aligned}$ & 2012 & & & & & & & & & & & \\
\hline $\begin{array}{l}\text { Aearation nnid } \\
\text { Caustic Feed System }\end{array}$ & ffulf floor a earation girid & $1.5 \mathrm{hp}$ & $\frac{\mathrm{cs}}{\mathrm{cs}}$ & $\frac{1}{4}$ & $\begin{array}{l}\$ 2,500,000 \\
520,000 \\
\end{array}$ & $\frac{2012}{2012}$ & $\$ 20,000$ & COD & 5600 & $\mathrm{~kg} / \mathrm{hr}$ & 0.60 & 3. & & 0.35 & & 59,860 & $\$ 29,579$ \\
\hline \begin{tabular}{|l|l|} 
Blowers \\
Membrane Bioreactor
\end{tabular} & 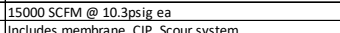 & 1000 hp ea & $\frac{c s}{c s}$ & 9 & $\begin{array}{l}\$ 2,070,000 \\
\$ 489850\end{array}$ & $\frac{2012}{2012}$ & $\begin{array}{ll}52,070,000 \\
5 \$ 890500\end{array}$ & COD & 5600 & $\mathrm{~kg} / \mathrm{hr}$ & 0.60 & 2. & 195 & 0.35 & $\frac{51,101,310}{52007250}$ & $\frac{51,020,492}{652777218}$ & 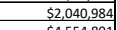 \\
\hline \begin{tabular}{|l} 
Membrane Bioreactor \\
Pump, Centrifugal, MBR, RAS
\end{tabular} & & $\begin{array}{l}85 \mathrm{hea} \\
160 \mathrm{hp} \\
\end{array}$ & $\frac{c s}{c s}$ & $\frac{1}{6}$ & $\begin{array}{l}\$ 4,98,500 \\
\text { INCLODED } \\
\end{array}$ & $\frac{2012}{2012}$ & & & & & 1.00 & & & & & & \\
\hline Gravity Belt Thickeners, & $2 \mathrm{~m}$ presses & $\frac{100 \mathrm{np}}{48 \mathrm{p}}$ & $\frac{\mathrm{cs}}{\mathrm{cs}}$ & $\frac{6}{3}$ & $\$ 750,000$ & $\frac{2012}{2012}$ & 5750,000 & COD & 5600 & $\mathrm{~kg} / \mathrm{hr}$ & 0.60 & 1. & 195 & 0.35 & $\$ 399,025$ & $\$ 369,744$ & 5587,892 \\
\hline 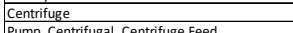 & & $\begin{array}{ll}165 \mathrm{hp} \text { ea } \\
15 \mathrm{ba}\end{array}$ & $\frac{\mathrm{cs}}{\mathrm{cs}}$ & $\frac{1}{2}$ & $\begin{array}{l}\$ 686,800 \\
\end{array}$ & $\frac{2012}{2012}$ & $\frac{5306,800}{5680}$ & $\frac{\mathrm{COD}}{\mathrm{CO}}$ & 5600 & $\frac{k g}{k g / h r}$ & 0.60 & 2. & $\frac{195}{195}$ & 0.35 & 5365,401 & $\begin{array}{ll}5338,586 \\
\end{array}$ & $\$ 910,098$ \\
\hline $\begin{array}{l}\text { Pump, Centrifugal, Centrifife Feed } \\
\text { Pump, Submersile, Centrate }\end{array}$ & $\frac{\frac{105 \mathrm{gm}}{10 \mathrm{gpm}}}{1 \mathrm{gpm}}$ & $\begin{array}{l}15 \mathrm{hp} \\
10 \text { hpea }\end{array}$ & $\frac{\mathrm{cs}}{\mathrm{cs}}$ & & $\begin{array}{l}\frac{\text { INCLUEDD }}{\text { INCLUDED }} \\
\end{array}$ & $\frac{2012}{2012}$ & & & & & & & & & & & \\
\hline $\begin{array}{l}\text { Pump, } \text {, ubomersible, Centrate } \\
\text { Dewatering Polymer Addition }\end{array}$ & $9.8 \mathrm{gph}$ neat polymer & $\begin{array}{l}10 \mathrm{hppa} \\
1 \text { hpea }\end{array}$ & $\frac{\mathrm{cs}}{\mathrm{cs}}$ & $\frac{2}{2}$ & $\begin{array}{l}\text { INCLUUED } \\
\text { INCLUDED }\end{array}$ & $\frac{2012}{2012}$ & & & & & & & & & & & \\
\hline \begin{tabular}{|l|l|} 
Conveyor \\
Rever
\end{tabular} & & 10 hpea & $\frac{\mathrm{cs}}{\mathrm{cs}}$ & $\frac{1}{7}$ & 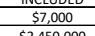 & $\frac{2012}{2012}$ & 57,000 & $\begin{array}{cl}C O D \\
H\end{array}$ & 560 & kg/hr & 0.60 & 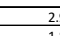 & 1956 & 0.35 & $\begin{aligned} 53,724 \\
510,023\end{aligned}$ & $\begin{aligned} \$ 3,451 \\
513004\end{aligned}$ & 59,870 \\
\hline & $368 \mathrm{gpm}$ & 1480 hpea & Titanium & 1 & $\frac{3,450,000}{550000}$ & $\frac{2012}{2012}$ & & $\begin{array}{l}\text { Hydraulic llow } \\
\text { Hydraulic flow }\end{array}$ & & & & & & & & & \\
\hline $\begin{array}{l}\text { Evaporator } \\
\text { Ammonia Addition System } \\
\end{array}$ & $0.63 \mathrm{kgm}$ & $4.5 \mathrm{hp}$ & cs & 4 & 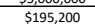 & $\frac{2012}{2012}$ & \$5,000,000 & & $\frac{2 .}{560}$ & 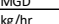 & $\frac{0.06}{0.06}$ & 1.1 & $\frac{1 .}{195}$ & 0.61 & $\begin{array}{l}\$ 3,723,638 \\
\$ 503853\end{array}$ & 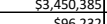 & $\frac{55.55,119}{5198197}$ \\
\hline Sodium Sulfate Puification & & & & & & & & & & 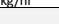 & 0.00 & & & & 5103,853 & & \\
\hline Evaporator feed tank & insulated, $6460 \mathrm{gal}$ & & & & $\$ 45,966$ & 2011 & 545,966 & strm.A600.23 & 290932 & kg/hr & 0.60 & 2.5 .5 & 2379966 & 8.18 & 5162,220 & 150033.3809 & $\$ 375,083$ \\
\hline $\begin{array}{l}\text { Evaporator feed heater } \\
\text { Fyanotorflastiom }\end{array}$ & 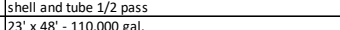 & & 58316 & & $\frac{\$ 274,818}{5 \leqslant 1002}$ & & 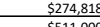 & heat.A600.31 & -13 & & & & & & $\begin{array}{ll}5195,585 \\
53201025\end{array}$ & $\begin{array}{l}180891.736 \\
27135937 \\
\end{array}$ & $\$ 542,675$ \\
\hline $\begin{array}{l}\text { Evaporator flash drum } \\
\text { Centrifuge }\end{array}$ & 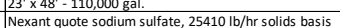 & & 55336 & $\frac{1}{1}$ & $\begin{array}{l}\$ 51,1,000 \\
\$ \$ 22,680\end{array}$ & $\frac{2009}{2011}$ & $\$ \$ \$ 511,000$ & & $\frac{264116}{11522}$ & gkghr & 0.70 & $\frac{2.0}{2}$ & 2379966 & $\frac{9.01}{1.25}$ & 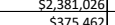 & 2471358.137 & $\frac{54,942,716}{5798690}$ \\
\hline $\begin{array}{l}\text { Lenthrige } \\
\text { Drver }\end{array}$ & 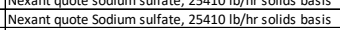 & & & $\frac{1}{1}$ & $\begin{aligned} 532,680 \\
555,008 \\
\end{aligned}$ & $\frac{2011}{2011}$ & 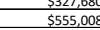 & 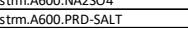 & $\frac{11524}{11524}$ & $\mathrm{~kg} / \mathrm{kgr}$ & $\frac{0.60}{0.60}$ & $\frac{2}{2}$. & $\frac{14458}{1377}$ & $\frac{1.25}{1.19}$ & $\frac{535,4642}{5617,592}$ & $\frac{544,256}{\$ 571,197}$ & $\frac{5 / 98,689}{51,485,111}$ \\
\hline & & & & & & & & & & & & & & Area 600 Totals & $\$ \$ 17,514,146 \mid$ & $\$ 16,491,606$ & $\$ 31,275,951$ \\
\hline
\end{tabular}




\begin{tabular}{|c|c|c|c|c|c|c|c|c|c|c|c|c|c|c|c|c|c|}
\hline A700: Lignin Utilization & Mechanical Equipn & ent List & & & & & & & & & d lnstall: & Costs & & & & & \\
\hline EQUIPMENT TITLE & DESCRIPTION & НP & MATERIAL & 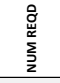 & $\$$ & 年 & $\begin{array}{c}\text { Purch cost in } \\
\text { Base } \mathrm{Yr}\end{array}$ & scaling Variable & 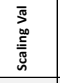 & $\frac{2}{5}$ & 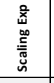 & 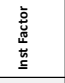 & 垔 & 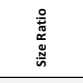 & $\begin{array}{l}\text { Scaled Purch } \\
\text { Coost }\end{array}$ & $\begin{array}{c}\text { Purch cost in } \\
\text { Proj year }\end{array}$ & $\begin{array}{c}\text { Inst Cost in Proj } \\
\text { year }\end{array}$ \\
\hline 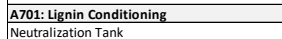 & & & & & & & & & & & & & & & & & \\
\hline 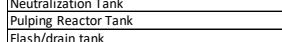 & 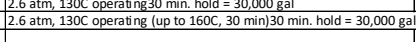 & & $\begin{array}{l}\frac{53317}{53316} \\
5327\end{array}$ & $\frac{1}{1}$ & $\begin{aligned} 233,000 \\
16,300,000 \\
\$ 26000\end{aligned}$ & $\begin{array}{l}2009 \\
2013 \\
2013\end{array}$ & 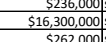 & 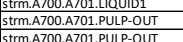 & $\begin{array}{ll}4130369 \\
323295 \\
3323296\end{array}$ & kg/hr & $\begin{array}{l}0.70 \\
0.60 \\
0.70\end{array}$ & $\begin{array}{l}2.0 \\
1.7 \\
\end{array}$ & $\begin{array}{l}108129 \\
140578 \\
130578\end{array}$ & $\frac{0.26}{0.43}$ & $\begin{aligned} \$ 592,799 \\
59,88,598 \\
51465259\end{aligned}$ & $\begin{aligned} 59,6,299 \\
59,43,319 \\
5139.599\end{aligned}$ & $\begin{aligned} & \$ \$ 192,298 \\
& \$ 15,581,477 \\
& \$ \$ 27938\end{aligned}$ \\
\hline 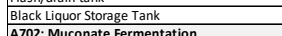 & $1,200,000$ gallon & & 31655 & $\frac{1}{1}$ & $\begin{array}{l}\$ 1,317,325 \\
\$ 51,31,325 \\
\end{array}$ & $\frac{2011}{2011}$ & $\begin{array}{ll}51,317,325 \\
5\end{array}$ & stm.A70.A701.5 & 328984 & kglime & 0.70 & $\frac{2.8}{1.8}$ & 92878 & $\frac{0.28}{0.28}$ & 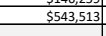 & $\begin{array}{ll}5.5302,682 \\
5022\end{array}$ & $\frac{3253.82}{5904.828}$ \\
\hline 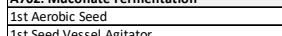 & 80 gallon skid complete - 546,000 ea & & 30455 & -1 & $\frac{54,000}{65000}$ & 2009 & $\frac{546,000}{6020}$ & 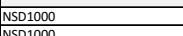 & & ea & 1.00 & 1.80 & & 4.00 & $\frac{\$ 184,000}{\$ \$ 3.000}$ & $\begin{array}{l}5190,981 \\
5019\end{array}$ & $\$ 344,765$ \\
\hline 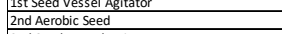 & 800 gallon skid complete - $\$ 57,500 \mathrm{ea}$ & 0.75 he & $\frac{5336}{30455}$ & & $\begin{aligned} \$ 3,420 \\
\$ 57,500 \\
\end{aligned}$ & $\frac{2009}{2009}$ & $\begin{aligned} \$ 3,42 \\
55,50 \\
\end{aligned}$ & $\begin{array}{l}\text { NSS51000 } \\
\text { NSD 1000 }\end{array}$ & & ea & $\frac{1.00}{1.00}$ & $\frac{1.50}{1.80}$ & & $\frac{4.00}{4.00}$ & $\begin{aligned} 13,3600 \\
5230,000 \\
\end{aligned}$ & $\begin{aligned} 544,99 \\
5238,726\end{aligned}$ & $\begin{aligned} 5.12,298 \\
5429,706 \\
\end{aligned}$ \\
\hline 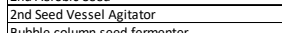 & (1) & $8 \mathrm{hp}$ & 55316 & & $\begin{array}{l}\$ 11,000 \\
\$ \$ 17000\end{array}$ & 2009 & $\begin{aligned} 511,000 \\
57010\end{aligned}$ & 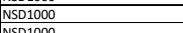 & 1 & ean & 1.00 & 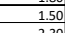 & & 4.00 & $\begin{aligned} 544,000 \\
\end{aligned}$ & $\begin{array}{l}545,669 \\
54\end{array}$ & 5058,5004 \\
\hline $\begin{array}{l}\text { Bublel columm seddedmenter } \\
\text { Seed circulation coler }\end{array}$ & $\begin{array}{lll}1000 \mathrm{~m} 3 \\
650 \mathrm{ftt}\end{array}$ & & $\begin{array}{l}31565 \\
31655 \\
\end{array}$ & 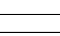 & $\begin{array}{c}527,400 \\
58,400 \\
\end{array}$ & 2014 & $\begin{aligned} 5274,400 \\
58,400 \\
\end{aligned}$ & $\begin{array}{l}\text { NSSD10000 } \\
\text { NSDD000 }\end{array}$ & & eat ea & $\begin{array}{ll}1.00 \\
1.00 \\
\end{array}$ & $\begin{array}{l}2.30 \\
2.20 \\
\end{array}$ & & 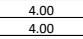 & $\begin{array}{ll}51,090,4000 \\
553,600\end{array}$ & $\begin{array}{ll}51,030,9324 \\
531,594 \\
\end{array}$ & $\begin{array}{ll}52,377,1,43 \\
569,506 \\
\end{array}$ \\
\hline 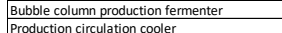 & $\begin{array}{lll}10000 \mathrm{~m} 3 \\
450 \text { soft }\end{array}$ & & 31655 & ב- & $\frac{\$ 1,691,400}{\$ 48,100}$ & $\frac{2014}{2014}$ & $\begin{array}{ll}\$ 1,691,400 \\
\$ 48,00\end{array}$ & $\begin{array}{l}\text { NVES1000 } \\
\text { NNES15000 }\end{array}$ & & ea & $\begin{array}{ll}1.00 \\
100\end{array}$ & 2.30 & $\frac{11}{11}$ & $\begin{array}{l}19.00 \\
1900\end{array}$ & $\begin{aligned} 532,136,600 \\
\$ 5913000\end{aligned}$ & 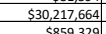 & 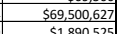 \\
\hline 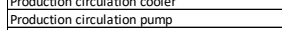 & 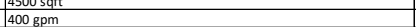 & & $\begin{array}{l}31635 \\
31655 \\
\end{array}$ & & $\begin{array}{l}\$ 48,100 \\
\$ 11,500 \\
\end{array}$ & 2014 & $\begin{array}{l}54,100 \\
\$ 11,500 \\
\end{array}$ & 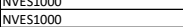 & & & $\begin{array}{ll}1.00 \\
1.00\end{array}$ & $\frac{2.20}{2.30}$ & & $\frac{19.00}{19.00}$ & $\begin{array}{l}513,3000 \\
5218,500 \\
\end{array}$ & $\begin{array}{l}588,929.9 \\
5205,453\end{array}$ & $\begin{array}{ll}\frac{\$ 1,890,525}{\$ 472,542} \\
\end{array}$ \\
\hline Fermentation air compressor & 25,000 ACFM @ 45psig; max size in ACCE & & cs & & $\$ 1,318,600$ & 2014 & $\$ 1,318,600 \mid$ & AlRv1000 & & 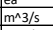 & $\frac{1.00}{1.00}$ & $\begin{array}{l}2.30 \\
1.60\end{array}$ & & 0.88 & $\begin{array}{l}\$ \$ 11,550304 \\
\$ 1,394 \\
\end{array}$ & 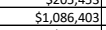 & 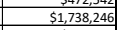 \\
\hline 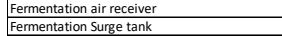 & $\begin{array}{l}2,5000 \mathrm{ogal} \\
\text { 2insulted cone bottom, } 6450 \mathrm{gal}\end{array}$ & & cs & & $\frac{5104,600}{5 \$ 5,966}$ & $\frac{2014}{2011}$ & $\begin{aligned} \$ 104,600 \\
\$ 55,966\end{aligned}$ & 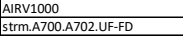 & & 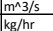 & $\frac{1.00}{0.60}$ & $\frac{2.00}{2.50}$ & $\frac{12}{187319}$ & 0.88 & $\begin{array}{ll}\$ 11,653 \\
\$ 532,25 \\
\end{array}$ & $\begin{array}{lll}586,181 \\
332643\end{array}$ & $\frac{5172,361}{\$ 81,608}$ \\
\hline $\begin{array}{l}\text { Ultrafiltration membrane separatoto } \\
\text { membiane broth feedd ump }\end{array}$ & & & & & 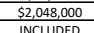 & 2011 & $52,048,000$ & 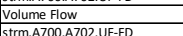 & 1303 & $\frac{G P M}{G P M}$ & 0.60 & 2.50 & 813 & 1.00 & $\$ 2,048,000$ & $\$ 1,, 894,146$ & $\begin{array}{lll}54,735,366 \\
5\end{array}$ \\
\hline $\begin{array}{l}\text { membrane b roth feed dump } \\
\text { membrane solvent fed pump } \\
\end{array}$ & & & & & $\begin{array}{l}\text { INCLODED } \\
\text { INCLODED } \\
\end{array}$ & & & 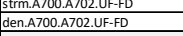 & & 锬/r & & & $\frac{187319}{1.0}$ & & & & \\
\hline 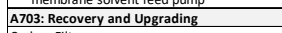 & & & & & 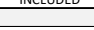 & & & 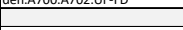 & & & & & & & & & \\
\hline Carbon Filter & 2 Vessels, for color removal & & & & 5345,234 & 2011 & 5345,234 & Volume Flow & & GPM & 0.60 & 2.50 & & 1.00 & $\$ 345,234$ & $\$ 319,299$ & 5798,247 \\
\hline Initial carbon loading & & & & & SEe CAAALYST & 2011 & & 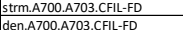 & & keg/r & & & $\frac{17242}{11}$ & & & & \\
\hline CCM Crystallizer & Oslo Type. 2 In series & & 31655 & 2 series & $\$ 7,104,192$ & 2011 & $57,104,192$ & $\begin{array}{l}\text { Volume flow } \\
\text { Volm }\end{array}$ & & SPM & 0.60 & 2.50 & $\begin{aligned} 45.396 \\
.325\end{aligned}$ & 0.24 & $53,009,338$ & $52,783,265$ & $56,958,162$ \\
\hline & & & & & & & & 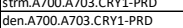 & & 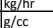 & 0.600 & 2.50 & & & & & \\
\hline $\begin{array}{ll}\text { CCM Centrifuge } \\
\text { CMC }\end{array}$ & Centrifuge Separator & & & & 5327,680 & 2011 & 5327,680 & 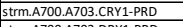 & 1340 & glight & 0.60 & 2.30 & 12245 & 0.91 & $\$ 310,384$ & 5287,067 & \\
\hline CCcM Drier & Fludidized bed drier parallel & & & 2 paralle & $\begin{array}{ccc}5555,008 \\
61017205\end{array}$ & 2011 & 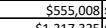 & 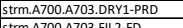 & $\frac{11526}{32090}$ & eg/hth & 0.60 & 2.60 & 11640 & 1.01 & 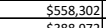 & $\frac{5516,36}{56275}$ & S1,342,537] \\
\hline Uissolutunt lank & 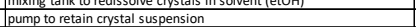 & 80 & 31655 & & $\frac{51,13,325}{5600}$ & $\frac{2011}{2009}$ & 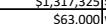 & 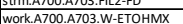 & 32898 & & 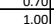 & 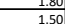 & 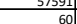 & $\frac{0.18}{100}$ & $\frac{3358,952}{5600}$ & $\frac{5359,751}{556390}$ & $\frac{5679,51}{598585}$ \\
\hline Filtration Centififuge(salt removall) & removes precipitated solids after dissolution & ב & $x_{-1}$ & & 5327,680 & 2011 & 5327,680 & strm.A700.A703.FIL-SLT & $\begin{array}{lll}1340 \\
\end{array}$ & & 0.60 & 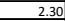 & $15: 4$ & 0.01 & $\$ 22,923$ & $\frac{521,20}{3}$ & 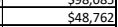 \\
\hline HDO feed tank & Iinsulated, 6460 gal & & & & 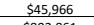 & 2011 & 545,966 & 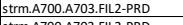 & 290933 & Kkghtre & 0.60 & 2.50 & 574322 & 0.20 & $\$ 17,364$ & & 50,149 \\
\hline $\begin{array}{l}\text { HDO reactor pump } \\
\text { HDO Feed Effluent econimizer }\end{array}$ & 2-4 TEMA shell and tube $\mathrm{HX}$ & & 31655 & & $\begin{aligned} \frac{5020,861}{5353,600} \\
\end{aligned}$ & 2011 & $\begin{aligned} \$ 8820,8161 \\
\$ 353,600 \\
\end{aligned}$ & 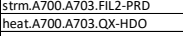 & 208726 & 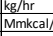 & $\begin{array}{l}0.080 \\
0.70\end{array}$ & $\frac{1.40}{2.66}$ & $\frac{57432}{3}$ & 0.28 & $\frac{\$ \$ 28,5633}{\$ 113,073}$ & $\frac{\$ 5268888}{\$ \$ 104,578}$ & $\begin{array}{l}\$ 336,443 \\
\$ 27,742 \\
\end{array}$ \\
\hline \begin{tabular}{|l|} 
HDO trim preheater \\
HDO Fixed Red Reactor
\end{tabular} & 103 F17 milestone), base $\mathrm{PF}=2.52,208 \mathrm{BBL} / \mathrm{hr}$ & & 30455 & & $\begin{array}{c}\$ 41,000 \\
\$ 4,168.588\end{array}$ & $\frac{2009}{2011}$ & $\begin{aligned} \$ 41,000 \\
\$ 4,168,58\end{aligned}$ & 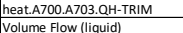 & 328951 & MMkcall & 0.70 & $\frac{2.20}{2.00}$ & $\frac{0.0}{71584}$ & $\frac{0.00}{2.18}$ & $\begin{aligned} 50 \\
57.184 .024\end{aligned}$ & $\begin{aligned} 50 \\
56.644333 \\
\end{aligned}$ & $\begin{aligned} 50 \\
513288656 \\
5\end{aligned}$ \\
\hline $\begin{array}{l}\text { Hov Fixed Bed Keactor } \\
\text { Pressure Factor (via Guthrie) }\end{array}$ & 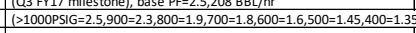 & & 1.6 & & 34,160,3608 & 2011 & $34,168,568$ & 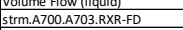 & 292974 & $\mathrm{Lkg} / \mathrm{hr}$ & 0.10 & 2.00 & $\frac{11544}{57432}$ & 2.18 & $57,184,024$ & $36,644,333$ & $\$ 13,288,666$ \\
\hline Intemals & & & & & & & & & & & & & & & & & \\
\hline $\begin{array}{l}\text { Hydrogenation Intercoolet (bed1) } \\
\text { Hydroenantion Intercooler (bed2) }\end{array}$ & & & & & $\frac{\$ 2,353,181}{\$ 2,33311}$ & $\frac{2007}{2007}$ & 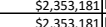 & 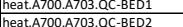 & & 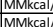 & 0.65 & $\frac{2.21}{2.21}$ & & 0.06 & 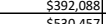 & $\begin{array}{l}5444,252 \\
56421\end{array}$ & 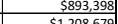 \\
\hline Hz Makeup Compressor or & recipiricating compress sor[5 stagess) & & & & $\frac{151,61,200}{51,200}$ & 2011 & s1,612,200| & stm.A700.A703..12-MU & 3900 & $\frac{1 k g / h r}{k k / h}$ & 0.60 & 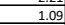 & 422 & 1.09 & 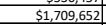 & & 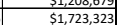 \\
\hline H2 Makeup Compressor spare & Irecipicicting compres sor(5 stages) & & & & $51,621,200$ & 2011 & $\$ 1,621,200$ & strm.A700.A703.H2-MU & & kg/hrt & 0.60 & 1.08 & & 1.09 & $\$ 1,709,652$ & S1,581,216 & 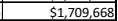 \\
\hline HHPS & Via Adipic model(Via MB) & & & & $\frac{5436,000}{5460}$ & 2013 & $\begin{array}{llll}5436,000 \\
6321000\end{array}$ & 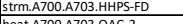 & 11984 & keg/hr & 1.00 & 1.50 & 5785: & 0.48 & $\$ 210,4944$ & 5200,99: & 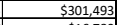 \\
\hline & 3.-Phase horizontal sep, demister, 3/16 SS516 cladding & & & & $\frac{323.500}{5338.50}$ & $\frac{2011}{2011}$ & 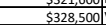 & & & & $\frac{2.70}{0.70}$ & $\begin{array}{l}\frac{1.59}{2.59} \\
\text {. }\end{array}$ & & $\frac{0.00}{0.00}$ & 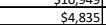 & 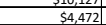 & $\frac{51.5}{511.5}$ \\
\hline & & & & & & & & Strm.A700.A703.CHPS- -1LQ & & kg/hr & & & & & & & -4 \\
\hline & linsulated 64600,020 & & & & & & & 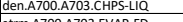 & & & & & & & & & \\
\hline 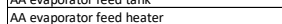 & 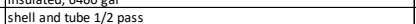 & & & & $\begin{array}{l}554,96 \\
\$ 274,818\end{array}$ & $\frac{201}{2011}$ & $\begin{array}{c}545,5966 \\
5274,818\end{array}$ & 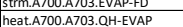 & 20934 & 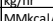 & 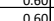 & 年. 300 & 101053 & 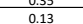 & $\begin{array}{l}324,433 \\
8104\end{array}$ & 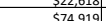 & S565.56 \\
\hline A evapoporator flash dium & $23^{\prime} \times 48^{\prime}-110,000$ gal. & & 55316 & 1 & 5511,000 & 2009 & $\begin{array}{l}5511,000 \\
\$ 5800 \\
\end{array}$ & 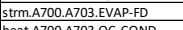 & 264116 & $\mathrm{~kg} / \mathrm{hr}$ & 0.70 & 2.00 & 101631 & 0.38 & $\begin{array}{lll}5261,867 \\
520,057\end{array}$ & $\begin{array}{lll}5271,802 \\
527020\end{array}$ & $\begin{array}{c}5543,605 \\
57300\end{array}$ \\
\hline AA crystallizizer & Oslo Type. 2 In series & & 31655 & 2 series & $\$ 7,104,192$ & 2011 & $\$ 7,104,192$ & Volume flow & & GPM & 0.00 & 2.50 & 46.641 & $\frac{0.25}{0.25}$ & $\$ 30,058,619$ & $\frac{\$ 2,9,360}{\$ 2,28,844}$ & $\frac{5582,209}{57,072,110}$ \\
\hline & & & & & & & & StetmA A70.0.A7030.C & & & & & & & & & \\
\hline AA Centrifuge separator & Centrifuge: & & & & 5327,680 & 2011 & $5327,680 \mid$ & 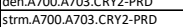 & & $\mathrm{kg} / \mathrm{ht} \mathrm{h}$ & $\frac{0.600}{0.60}$ & $\begin{array}{l}2.50 \\
230\end{array}$ & 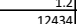 & 0.93 & $\$ 3132511$ & 5289719 & $\$ 666353$ \\
\hline AA D Drier & Fluidized bed drier parallel & & & 2 parallel & $\$ 55,000$ & 2011 & $\$ 555,008$ & Strm.A770.A703.0RY2-PRD & & $\mathrm{kg} / \mathrm{hr}$ & 0.60 & 2.60 & 11843 & 1.03 & $\$ 564,125$ & $\$ 521,746$ & $\$ 1,356,539$ \\
\hline & & & & & & & & & & & & & & ea 700 Total, & $\$ 70,327,252$ & $\$ 66,120,273$ & $\$ 139,957,048$ \\
\hline
\end{tabular}




\begin{tabular}{|c|c|c|c|c|c|c|c|c|c|c|c|c|c|c|c|c|c|}
\hline A800: CHP & Mechanical Equipment List & & & & & \multicolumn{12}{|c|}{ Scaled Installed Costs } \\
\hline EQUIPMENT TITLE & DESCRPPTION & HP & MATERIAL & 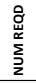 & $\$$ & 要 & $\begin{array}{c}\text { Purch cost in } \\
\text { Base } \mathrm{Yr}\end{array}$ & Scaling Variable & 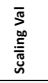 & $\frac{2}{5}$ & 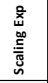 & 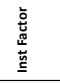 & $\begin{array}{l}\frac{\bar{s}}{3} \\
\frac{3}{2}\end{array}$ & 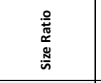 & $\begin{array}{l}\text { Scaled Purch } \\
\text { Cost }\end{array}$ & $\begin{array}{l}\text { Purch cost in } \\
\text { Proj year }\end{array}$ & $\begin{array}{c}\text { Inst cost in Proj } \\
\text { year }\end{array}$ \\
\hline 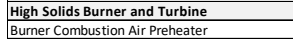 & & & & & & & & & & & & & & & & & \\
\hline 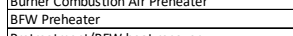 & $\begin{array}{l}\text { INCCLUDED } \\
\text { INCLUDD }\end{array}$ & & & $\frac{1}{1}$ & $\begin{array}{l}\text { INCLCOEDD } \\
\text { INCLUDED }\end{array}$ & & & & & & & & & & & & \\
\hline $\begin{array}{l}\text { Pretreatment/BFW heat recovery } \\
\text { Adirthake fan }\end{array}$ & $\begin{array}{l}9.4 \mathrm{MMB} B \mathrm{Bt} / \mathrm{hr} \\
1 \text { ICLODED }\end{array}$ & & 55304 & 1 & $\begin{array}{ll}541,000 \\
\text { INC1000 }\end{array}$ & 2009 & $\$ 41,000$ & heat.A800.A810.QH812 & - & Gcal/hr & 0.70 & 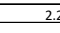 & & 0.72 & $\$ 32,711$ & $\$ 33,952$ & 574,694 \\
\hline Boiler & 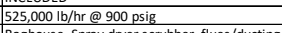 & & cs & 1 & $\frac{128,550,000}{52,55000}-150$ & 2010 & $\$ 28,550,000$ & strm.A800.A810.813c & 23820 & $\mathrm{~kg} / \mathrm{hr}$ & 0.60 & 1.8 & 230378 & 0.97 & $\$ 27,983,543$, & $\$ 27,521,215$ & $\$ 49,538,187$ \\
\hline 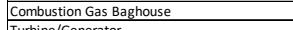 & Baghouse, Spray diver scrubber, flues/ducting & & & 1 & $\$ 11,000,000$ & 2013 & & strm.A800.A810.812 & 23820 & $\mathrm{~kg} / \mathrm{hr}$ & 0.60 & & & & & & \\
\hline 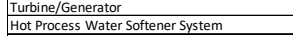 & & & & $\frac{1}{1}$ & $\begin{array}{l}\frac{59,50,000}{578,000} \\
5\end{array}$ & $\frac{2010}{2010}$ & $\begin{array}{l}59,50,0,000 \\
57,000 \\
\end{array}$ & $\begin{array}{l}\text { work.k9900.wotal } \\
\text { strm.A80.A810.812 } \\
\end{array}$ & $\frac{-4220}{23580}$ & $\mathrm{~kW} / \mathrm{kr}$ & $\begin{array}{ll}0.60 \\
0.60\end{array}$ & 1.8 & $\begin{array}{ll}-165228 \\
15798\end{array}$ & 0.39 & $\begin{aligned} 55,4131,41 \\
561,339 \\
\end{aligned}$ & $\begin{aligned} 55,322,003 \\
550,326 \\
\end{aligned}$ & $\begin{array}{l}59,588,250 \\
50108,566 \\
\end{array}$ \\
\hline 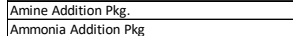 & & & & $\frac{1}{1}$ & $\begin{array}{ll}540,000 \\
\text { INCLODED }\end{array}$ & 2010 & 540,000 & strm.A800.A810.812 & $23580:$ & $\mathrm{kg} / \mathrm{hr}$ & 0.00 & 1.8 & 15798 & 0.67 & $\$ 40,000$ & $\$ 39,339$ & $\$ 70,810$ \\
\hline Phosphate Additition PRg. & & & & $\frac{1}{1}$ & $\begin{array}{l}\text { INELCUED } \\
\text { INCLODED }\end{array}$ & & & & & & & & & & & & \\
\hline $\begin{array}{l}\text { Condensate Pump } \\
\text { Then }\end{array}$ & & & 55316 & 2 & INCLUDED & & & & & & & & & & & & \\
\hline 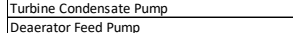 & & & $\frac{5 S 304}{55304}$ & $\frac{2}{2}$ & $\begin{array}{l}\text { INCLUDED } \\
\text { INLCDOED }\end{array}$ & & & & & & & & & & & & \\
\hline BEW Pump & & & 553316 & 5 & INCLUDED & & & & & & & & & & & & \\
\hline $\begin{array}{l}\text { Blowdown Pump } \\
\text { Amin Tranfer Pump }\end{array}$ & & & cs & 2 & $\begin{array}{l}\text { INCLUDED } \\
\text { ANCLOESO }\end{array}$ & & & & & & & & & & & & \\
\hline Condensate Collection Tank & & & A285C & 1 & $\begin{array}{ll}\text { INCCDOED } \\
\text { INCLUDED }\end{array}$ & & & & & & & & & & & & \\
\hline \begin{tabular}{|l} 
Condensate Surge Drum \\
Deaerator
\end{tabular} & Tray type & & $\frac{53504}{C 555316}$ & $\frac{1}{1}$ & INCLDED & 2010 & $\$ 305,000$ & strm.A800.A810.812 & 23580 & $\mathrm{~kg} / \mathrm{hr}$ & 0.60 & & 157987 & 0.67 & 5239.852 & $\$ 235,889$ & 5707,668 \\
\hline $\begin{array}{l}\text { Deaedarow Flash Drum } \\
\text { Blowdonn }\end{array}$ & Ifay trpe & & $\frac{c 5 s 3536}{c s}$ & $\frac{1}{1}$ & 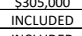 & 2010 & $\$ 305,000$ & & & $\mathrm{~kg} / \mathrm{hr}$ & 0.60 & & 15198 & 0.67 & 5239,822 & 5235,889 & $\$ 707,668$ \\
\hline & & & 55316 & & & & & & & & & & & Area 800 Totals & $\$ 33,770,886$ & $\$ 33,214,724$ & $\$ 60,083,151$ \\
\hline
\end{tabular}

\begin{tabular}{|c|c|c|c|c|c|c|c|c|c|c|c|c|c|c|c|c|c|}
\hline A900: Utilities \& Storage & & ent list & & & & & & & & & IInstal| & Costs & & & & & \\
\hline EQUIPMENT TITLE & DESCRPPTION & HP & MATERIAL & 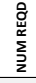 & $\$$ & (0) & $\begin{array}{c}\text { Purch cost in } \\
\text { Base } \mathrm{Yr}\end{array}$ & Scaling Variable & 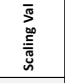 & $\frac{x^{2}}{5}$ & 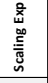 & 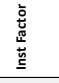 & $\begin{array}{l}\frac{\pi}{3} \\
\frac{3}{2}\end{array}$ & 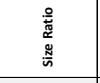 & $\begin{array}{c}\text { Scaled Purch } \\
\text { cost }\end{array}$ & $\begin{array}{c}\begin{array}{c}\text { Purch cost in } \\
\text { Proj year }\end{array} \\
\text { a }\end{array}$ & $\begin{array}{c}\text { Inst cost in Proj } \\
\text { vear }\end{array}$ \\
\hline $\begin{array}{l}\frac{\text { Utilitie S System }}{\text { Cooling Tower System }} \\
\end{array}$ & $44,200 \mathrm{gpm}$ & $750 \mathrm{hp}$ & FiBERGLASS & 1 & $\$ 1,375,000$ & 2010 & $51,375,000$ & Ettrm.a900.945 & 10037820 & $\mathrm{~kg} / / \mathrm{hr}$ & 0.60 & & 23291036 & 2.32 & & & \\
\hline $\begin{array}{l}\text { Plennt Air Compressor } \\
\text { Chillid Water rackage }\end{array}$ & $\frac{400 \text { CSFF@ } 125 \text { s5ig }}{223250 \text { tons }}$ & $\frac{150 \mathrm{hp}}{3400 \mathrm{hp}}$ & & $\frac{1}{1}$ & $\begin{array}{ll}\$ 12,000 \\
\$ 1,72,750 \\
\end{array}$ & $\frac{2010}{2010}$ & $\begin{array}{r}528,000 \\
51,27,750 \\
\end{array}$ & $\begin{array}{l}\text { DRY101 } \\
\text { heat.a900.qchw }\end{array}$ & $\begin{array}{r}83333 \\
14 \\
\end{array}$ & $\begin{array}{l}\mathrm{kg} / \mathrm{hr} \\
\mathrm{Gcal} / \mathrm{hr}\end{array}$ & $\begin{array}{l}0.60 \\
0.60 \\
\end{array}$ & & $\begin{array}{r}83333 \\
9 \\
\end{array}$ & $\begin{array}{l}1.00 \\
3.48 \\
\end{array}$ & $\begin{array}{l}528,000 \\
\$ 2,693,705 \\
\end{array}$ & $\begin{array}{r}5527,537 \\
52,649,201 \\
\end{array}$ & $\begin{array}{r}544,060 \\
54,238,722 \\
\end{array}$ \\
\hline $\begin{array}{l}\text { CIP System } \\
\text { Coplise Water Pummo }\end{array}$ & 100,000 GAL & & 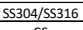 & 1 & 5421,000 & 2009 & 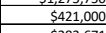 & 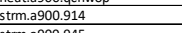 & 63 & kg/hr & 0.60 & 1.8 & $\frac{145}{145}$ & 2.30 & 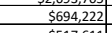 & 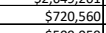 & \\
\hline $\begin{array}{l}\text { Cooling Water Pump } \\
\text { Make-up Water Pump }\end{array}$ & 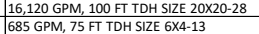 & $\frac{500.0}{20.0}$ & $\begin{array}{ll}c s \\
c s\end{array}$ & 3 & $\frac{5283,671}{56,64}$ & $\frac{2010}{2010}$ & $\frac{5283,671}{56,644}$ & $\begin{array}{l}\text { strm.a900.945 } \\
\text { stma.990.904 }\end{array}$ & $\frac{10982556}{155564}$ & $\mathrm{~kg} / \mathrm{hr}$ & $\begin{array}{c}0.80 \\
0.80\end{array}$ & $\frac{3.1}{3.1}$ & $\frac{23291036}{5229217}$ & $\frac{2.12}{3.30}$ & $\frac{5517,611}{518279}$ & $\frac{559,059}{5177977}$ & $\begin{aligned} \$ 1,578,083 \\
\$ 55,529 \\
\end{aligned}$ \\
\hline Processs Water Circulating Pump & 2285 GPM, 75 FT T TH SIIZE 8X6-13 & 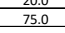 & $\frac{\mathrm{cs}}{\mathrm{cs}}$ & $\frac{1}{1}$ & $\begin{array}{ll}50,684 \\
51,292 \\
\end{array}$ & 2010 & $\frac{56,64}{515,292}$ & 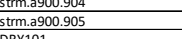 & $\frac{155644}{518924}$ & $\frac{\mathrm{kg} h \mathrm{hr}}{\mathrm{kg} / \mathrm{hr}}$ & $\frac{0.80}{0.80}$ & $\frac{3.1}{3.1}$ & $\begin{aligned} 529217 \\
803985 \\
\end{aligned}$ & $\begin{array}{l}\frac{3.40}{1.55} \\
\end{array}$ & $\frac{518,279}{521,706}$ & $\frac{51,9717}{521,347}$ & $\frac{555,79}{56,177}$ \\
\hline $\begin{array}{l}\text { Instrument Air Dryer } \\
\text { Plant AAR Receiver }\end{array}$ & 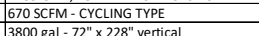 & & cs & 1 & $\begin{array}{ll}515,000 \\
516000\end{array}$ & 2009 & $\frac{515,000}{51600}$ & DRY101 & 88333 & $\mathrm{~kg} / \mathrm{hr}$ & 0.60 & & 88333 & 1.00 & $\frac{515,000}{516000}$ & $\begin{array}{lll}515,569 \\
51607\end{array}$ & $\frac{528,024}{551428}$ \\
\hline $\begin{array}{l}\text { Plant Air RReciver } \\
\text { Process Water Tank No. } 1\end{array}$ & 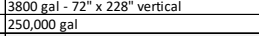 & & $\frac{c s}{c s}$ & $\frac{1}{1}$ & $\begin{array}{l}\$ 16,000 \\
\$ 250,000\end{array}$ & 2009 & $\begin{array}{l}\$ \$ 6,0,00 \\
\$ 250,000\end{array}$ & trm. & $\begin{array}{r}83333 \\
451555 \\
\end{array}$ & $\begin{array}{ll}\mathrm{kg} / \mathrm{hr} \\
\mathrm{kg} / \mathrm{hr}\end{array}$ & 0.60 & $\frac{5.7}{1.7}$ & 8303985 & $\frac{1.00}{1.78}$ & 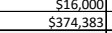 & 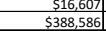 & $\begin{aligned} \$ \$ 1,482 \\
\$ 660,597\end{aligned}$ \\
\hline Storage & 28,000 gal & & SA-516-70 & & $\$ 196,000$ & & $\$ 196,000$ & Strm.A900.NH3-NET & 117 & $\mathrm{~kg} / \mathrm{hr}$ & 0.70 & & 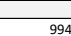 & - & & 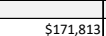 & \\
\hline 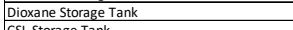 & $\begin{array}{l}28,000 \mathrm{gal} \\
7,00 \mathrm{a}\end{array}$ & & SA-516-70 & 2 & $\begin{array}{ll}5196,000 \\
519600\end{array}$ & 2010 & $\begin{array}{l}5196,000 \\
\$ \$ 19600\end{array}$ & trm.A500.FURANS.DIOXANE & 1171 & $\mathrm{~kg} / \mathrm{hr}$ & 0.70 & & 209 & 0.18 & 558,617 & 557,649 & (5345,2067 \\
\hline & 70,000 gal & & $\frac{6 \text { lass lined }}{53504}$ & $\frac{1}{1}$ & $\begin{array}{l}570,000 \\
521200\end{array}$ & 2009 & $\frac{57,000}{51200}$ & Strm.A900.CSL-NET & & $\mathrm{kg} / \mathrm{hr}$ & 0.70 & & & 0.17 & $\frac{52,084}{6.900}$ & $\frac{520,846}{6009}$ & $\frac{544}{512}$ \\
\hline $\begin{array}{l}\text { CSLL Ltorage Tank ABitator } \\
\text { CSL Pump }\end{array}$ & 8 GPM, $80 \mathrm{FT} \mathrm{TDH}$ & $\begin{array}{l}10 \mathrm{hp} \\
0.5 \\
\end{array}$ & \begin{tabular}{c|c}
53504 \\
$c 5$
\end{tabular} & $\frac{1}{1}$ & $\begin{array}{ll}\$ 12,200 \\
\$ 3,000\end{array}$ & 20009 & $\frac{\$ 21,2,00}{\$ 3,000}$ & $\begin{array}{l}\text { Stm.A900.CSLLNT } \\
\text { strm.A90.CSL-NET }\end{array}$ & $\begin{array}{r}13933 \\
1393 \\
\end{array}$ & $\mathrm{~kg} / \mathrm{hr} / \mathrm{hr}$ & 0.50 & $\frac{1.5}{3.1}$ & $\frac{234}{234}$ & 0.17 & $\begin{array}{r}58,600 \\
5720 \\
\end{array}$ & $\begin{aligned} 59,019 \\
5747 \\
\end{aligned}$ & $\frac{153}{52}$ \\
\hline $\begin{array}{l}\text { DAP Bulk Bag Unloader } \\
\text { DAP BAlk Ba H Holder }\end{array}$ & $\begin{array}{l}\text { Super sack unloader } \\
\text { Sumscrkbldder }\end{array}$ & & & 1 & $\begin{array}{ll}530,000 \\
50,0000\end{array}$ & 2009 & $\$ 30,000$ & Strm.A900.DAP-NET & $\frac{163}{163}$ & $\mathrm{~kg} / \mathrm{hr}$ & $\begin{array}{c}0.60 \\
0.60\end{array}$ & $\frac{1.1}{1.2}$ & 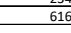 & 3.78 & 566,603 & 569,130 & $\frac{\$ 12,51}{\$ 117,521}$ \\
\hline 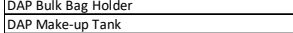 & $\begin{array}{l}\text { Suber rack holder } \\
12,800 \text { gal }\end{array}$ & & 55304 & & $\begin{array}{ll}\text { INECLUUED } \\
102000\end{array}$ & & $\$ 102.000$ & strm.A900.DAP-NET & & $\mathrm{kg} / \mathrm{hr}$ & & & & 0.38 & 551.941 & 553,912 & \\
\hline DAP Make-up Tank Agitator & & $5.5 \mathrm{hp}$ & $\frac{55304}{55304}$ & 1 & $\begin{array}{l}354,800 \\
5,800 \\
\end{array}$ & 20099 & $\begin{array}{ll}\frac{5102,000}{59,800} \\
\end{array}$ & 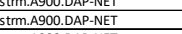 & $\begin{array}{r}1615 \\
163 \\
\end{array}$ & $\mathrm{~kg} / \mathrm{kr} / \mathrm{hr}$ & 0.50 & $\frac{1.8}{1.5}$ & $\frac{616}{616}$ & $\begin{array}{l}0.38 \\
.78 \\
\end{array}$ & $\begin{array}{c}\frac{351,444}{519,049} \\
\end{array}$ & $\begin{aligned} 53,9,124 \\
519,722\end{aligned}$ & 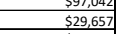 \\
\hline $\begin{array}{l}\text { DAA Pump } \\
\text { Sulfuric Acid Pump } \\
\end{array}$ & $\begin{array}{l}\frac{2 \text { GPM, }}{2} 1000 \text { F F TH } \\
5 \text { GPM, }\end{array}$ & $\begin{array}{l}0.5 \\
0.5 \\
\end{array}$ & $\frac{c s}{5 s 316}$ & $\frac{1}{1}$ & $\begin{array}{c}\frac{53,00}{57,093} \\
5793\end{array}$ & $\frac{2009}{2010}$ & $\begin{aligned} \$ 3,000 \\
\$ 7,933 \\
\end{aligned}$ & 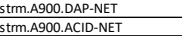 & $\begin{aligned} 163 \\
1981 \\
\end{aligned}$ & $\mathrm{~kg} / \mathrm{hr} / \mathrm{hr}$ & 0.80 & $\frac{3.1}{2.3}$ & $\frac{6616}{11560}$ & 3.78 & $\begin{aligned} \$ 8,6899 \\
\$ 30,727 \\
\end{aligned}$ & $\begin{array}{c}\frac{59,018}{\$ 30,220} \\
\end{array}$ & $\begin{array}{ll}527,957 \\
559,505\end{array}$ \\
\hline $\begin{array}{l}\text { Sulfuric Acid Storage Tank } \\
\text { Caustit Storage Tank }\end{array}$ & 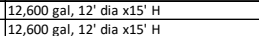 & & $\begin{array}{ll}5 s \\
5 s \\
5\end{array}$ & $\frac{1}{1}$ & $\begin{array}{ll}596,000 \\
5690000\end{array}$ & $\frac{2010}{2011}$ & $\begin{array}{cc}596,000 \\
596,000\end{array}$ & $\begin{array}{l}\text { strm.A900.ACID-NET } \\
\text { stm A000 BSEN-NET }\end{array}$ & $\begin{array}{l}1981 \\
1981 \\
\end{array}$ & $\begin{array}{ll}\mathrm{kg} / \mathrm{hr} \\
\mathrm{kg} / \mathrm{hr}\end{array}$ & $\frac{0.70}{0.70}$ & $\frac{1.5}{1.5}$ & $\frac{11560}{10271}$ & $\begin{array}{c}5.84 \\
5.18\end{array}$ & $\begin{array}{l}\frac{\$ 330,012}{\$ \$ 303,301} \\
\end{array}$ & 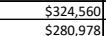 & $\begin{array}{lll}5486,840 \\
5421.167\end{array}$ \\
\hline Aclis Storage Tank & $12,600 \mathrm{gal}, 122^{\prime} \mathrm{dia} \times 15^{\prime} \mathrm{H}$ & & $\frac{55}{5 s}$ & 1 & 596,000 & 2011 & $\begin{array}{c}596,000 \\
590,000\end{array}$ & 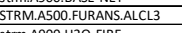 & $\begin{array}{l}1981 \\
1981 \\
-12\end{array}$ & $\mathrm{~kg} / \mathrm{hr}$ & 0.70 & $\frac{1.5}{1.5}$ & $\frac{949}{949}$ & 0.08 & 550,330 & $\begin{array}{ll}5253,023 \\
553,023 \\
50\end{array}$ & 5979,534 \\
\hline Firewater Storage Tank & 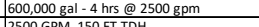 & & $\begin{array}{c}\text { Glass lined } \\
\text { Sc }\end{array}$ & 1 & $\frac{5803,000}{51500}$ & 2009 & $\frac{\$ 803,000}{\$ 5000}$ & strm.A900.H2O-FIRE & 8343 & $\mathrm{~kg} / \mathrm{hr}$ & 0.70 & & 8343 & 1.00 & $\$ 803,000$ & $\$ 833,464 \mid$ & $51,416,890$ \\
\hline Fievater Pump & 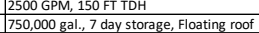 & 125.0 & $\frac{\mathrm{CS}}{\mathrm{A285 \textrm {C }}}$ & $\frac{1}{1}$ & $\begin{array}{l}\$ 15,000 \\
\$ 670,000 \\
\end{array}$ & $\frac{2009}{2009}$ & $\begin{aligned} \$ 515,000 \\
\$ 6600000\end{aligned}$ & $\begin{array}{l}\text { strm.A900.020O-FRRE } \\
\text { strm.PRD-500 }\end{array}$ & $\begin{array}{r}8343 \\
1341 \\
\end{array}$ & $\mathrm{~kg} / \mathrm{hr}$ & 0.80 & $\frac{3.1}{1.1}$ & $\frac{8343}{28139}$ & $\begin{array}{l}1.00 \\
2.48 \\
\end{array}$ & $\begin{aligned} 515,0.00 \\
51,265,750\end{aligned}$ & $\frac{51,5,59}{\$ 1,313,370}$ & $\begin{aligned} 584,264 \\
52,233,409\end{aligned}$ \\
\hline 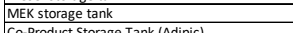 & 750,000 gall, 7 day storage, Floating roof & & A285C & 1 & $\begin{array}{ll}56670,000 \\
560000\end{array}$ & $\frac{2009}{2009}$ & $\begin{array}{l}\frac{3670,000}{5670,00} \\
560000\end{array}$ & 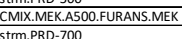 & $\frac{11341}{23322902}$ & $\frac{d g h t h r}{k g / h r}$ & 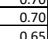 & $\frac{1.7}{1.85}$ & $\frac{2.2301}{93301}$ & $\begin{array}{ll}0.82 \\
0.0572502\end{array}$ & 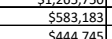 & 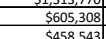 & 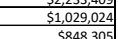 \\
\hline $\begin{array}{l}\text { Co-Product Storage Tank (Sodium Sulfate) } \\
\text { Glyors Strage Tank }\end{array}$ & & & 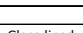 & 1 & $\begin{array}{ll}5050,900 \\
560900\end{array}$ & 2007 & $\begin{array}{ll}5050,900 \\
560,900\end{array}$ & 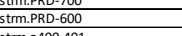 & 23322.902 & $\mathrm{kg} / \mathrm{hr}$ & 0.65 & $\frac{1.850}{1.850}$ & $\frac{1374}{1377}$ & 0.590406709 & 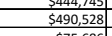 & $\frac{5453,545}{5505,746}$ & 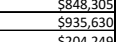 \\
\hline Glucose Storage Tank & $70,000 \mathrm{gal}$ & & Glass ined & & 570,000 & & & Strm.a400.401 & & & & & & Area 900 Totals & $\begin{array}{l}\$ / 4,060 \\
11,466,172 \\
\end{array}$ & $\begin{aligned} \$ 178,5579 \\
\$ 1158959\end{aligned}$ & $\$ 204,229$ \\
\hline & & & & & & & & & & & & & & Area 900 Totals & $\$ 11,466,172$ & $\$ 11,518,859$ & $\$ 19,955,2 S^{\circ}$ \\
\hline
\end{tabular}


Integrated Biorefinery

\begin{tabular}{|c|c|c|c|c|c|c|c|c|c|c|c|c|c|c|c|c|c|}
\hline A200: Pretreatment & & nt list & & & & & & & & & Instal & Costs & & & & & \\
\hline EQUIPMENT TITLE & DESCRIPTION & HP & MATERIAL & 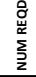 & $\$$ & 先 & $\begin{array}{c}\text { Purch cost in } \\
\text { Base } \mathrm{Yr}\end{array}$ & Scaling Variable & 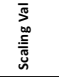 & $\frac{n}{5}$ & 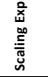 & 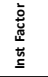 & 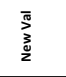 & 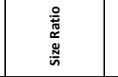 & $\begin{array}{l}\text { Scaled Purch } \\
\text { cost }\end{array}$ & $\begin{array}{l}\text { Purch cost in } \\
\text { Proj year }\end{array}$ & $\begin{array}{c}\text { Inst cost in Proj } \\
\text { year }\end{array}$ \\
\hline 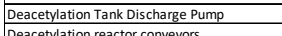 & 1771 GPM, 150 of TDH & 100 & $\begin{array}{lll}31655 \\
s 3615\end{array}$ & $\frac{1}{3}$ & $\$ 22,500$ & 2009 & $\frac{52,500}{591,500}$ & strm.a200.211a & 402194 & $\mathrm{~kg} / \mathrm{hr}$ & 0.80 & & 283668 & 0.71 & $\begin{array}{l}\$ 17,017 \\
\$ \$ 230170 \\
5\end{array}$ & 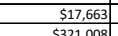 & $\frac{540,624}{5555,7313}$ \\
\hline & Feed and discharge drag conveyors & & & $\frac{3}{1}$ & $\begin{array}{l}\$ 110,000 \\
\$ 5,424,000 \\
\end{array}$ & $\frac{2013}{2010}$ & $\begin{aligned} \$ 1910,000 \\
\$ 55,424,000\end{aligned}$ & 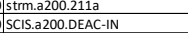 & 277767 & $\mathrm{~kg} / \mathrm{hr}$ & $\begin{array}{l}0.80 \\
1.00 \\
\end{array}$ & & 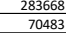 & $\frac{1.102}{1.83}$ & $\begin{aligned} \$ 933,6,178 \\
\$ 9,904,187\end{aligned}$ & $\begin{array}{c}\$ 321,1008 \\
\$ 9,740,555\end{array}$ & $\begin{array}{r}\$ 545,713 \\
599,70,555 \\
\end{array}$ \\
\hline Flash Tank ABgitator & Sidid-mounted, $3 \times 75$ h.p. (170 kW) & $170 \mathrm{~kW}$ & 316 liss & 3 & $\begin{array}{l}590,000 \\
3000\end{array}$ & 2009 & $\frac{50,44,000}{\$ 90,000}$ & strm.2200.254 & 252891 & $\mathrm{~kg} / \mathrm{hr}$ & 0.50 & & 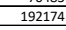 & 0.76 & 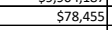 & $\frac{58,432}{582}$ & 5122,148 \\
\hline $\begin{array}{c}\text { Ammonia Addition Tank Agitator } \\
\text { nat }\end{array}$ & & $10 \mathrm{hp}$ & & 1 & $\begin{array}{ll}521,900 \\
5500\end{array}$ & 2009 & $\frac{\$ 21,900}{5500}$ & sttm.a200.228 & 410369 & $\mathrm{~kg} / \mathrm{hr}$ & 0.50 & & 230674 & 0.56 & $\begin{array}{l}\$ \$ 16,419 \\
\end{array}$ & $\$ 17,042$ & 525,563 \\
\hline $\begin{array}{l}\text { Ammonia Static Mixer } \\
\text { Pretreatment Water Heater }\end{array}$ & & & $\begin{array}{c}55 \\
30455 \\
3\end{array}$ & $\frac{1}{1}$ & $\begin{array}{ll}55,000 \\
52,000\end{array}$ & $\frac{2009}{20010}$ & $\begin{array}{ll}55,000 \\
52,000\end{array}$ & 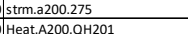 & $\begin{array}{r}157478 \\
-8\end{array}$ & keghr & $\frac{0.50}{0.70}$ & & $\frac{38501}{-0.3}$ & 0.24 & $\frac{52,472}{59967}$ & $\begin{array}{c}52,566 \\
557904\end{array}$ & $\frac{\$ 2,566}{\$ 51348}$ \\
\hline $\begin{array}{l}\text { Pretreatment werer heater } \\
\text { Milling Equipment }\end{array}$ & $\begin{array}{l}2.90 \mathrm{9mMBSt} \\
200 \mathrm{k} w \mathrm{~d} \text { ton }\end{array}$ & & 30455 & $\frac{1}{8}$ & $\begin{array}{l}\$ \$ 2,0,00 \\
\$ 2,46,700 \\
\end{array}$ & $\frac{2010}{2013}$ & $\frac{\$ 52,000}{\$ 2,46,700}$ & $\begin{array}{l}\text { Heat.A200.0.0201201 } \\
\text { Iscis.2020.211b }\end{array}$ & $\begin{array}{r}-8 \\
62942 \\
\end{array}$ & $\begin{array}{l}\text { Gaca/hr } \\
\mathrm{kg} / \mathrm{hr}\end{array}$ & 0.60 & & $\begin{array}{r}-0.3 \\
57306\end{array}$ & $\frac{0.94}{0.91}$ & $\frac{59,867}{519,733,600}$ & $\begin{array}{r}\$ 9,78,74 \\
\$ 18,84,101 \\
\end{array}$ & $\frac{\$ 28,21348}{528,651}$ \\
\hline 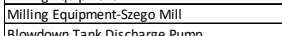 & & & & 11 & $\$ 5578,000$ & 2013 & $\frac{51450,000}{\$ 578,000}$ & scls. $2200.2121 \mathrm{~b}$ & $\frac{62942}{62942}$ & $\mathrm{~kg} / \mathrm{hr}$ & 0.60 & & 57306 & 0.91 & $\$ \$ 6,358,000$ & 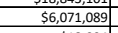 & 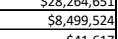 \\
\hline $\begin{array}{l}\text { Blowdown lann Vischarge Pump } \\
\text { Flash Tank Discharge Pump }\end{array}$ & $\begin{array}{l}1900 \text { G GM, , } 150 \text { F T D DH } \\
900 \text { GP, } 150 \text { T TDH }\end{array}$ & $\frac{125}{75}$ & $\begin{array}{l}33655 \\
31655 \\
\end{array}$ & $\frac{1}{1}$ & $\begin{array}{l}\$ 525,655 \\
530,000 \\
\end{array}$ & $\frac{2010}{2009}$ & $\frac{\$ 525,635}{\$ \$ 30,000}$ & $\begin{array}{l}\text { sttm.m.2200.222 } \\
\text { stma2200.254 }\end{array}$ & $\begin{array}{l}29240790 \\
20490\end{array}$ & $\mathrm{~kg} / \mathrm{hr}$ & $\begin{array}{l}0.80 \\
0.80 \\
\end{array}$ & & 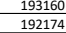 & 0.66 & $\begin{array}{l}\$ 18,398 \\
\$ 28,557 \\
\end{array}$ & $\left|\begin{array}{l}\$ 18,0994 \\
\$ 29,640\end{array}\right|$ & $\begin{aligned} 514,671 \\
568,172 \\
\end{aligned}$ \\
\hline Hydrolyzate Pump & 1771 GPM, 150 F T TDH & 100 & 31655 & & 522,500 & 2009 & $\$ \$ 22,500$ & 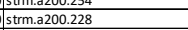 & 402194 & $\frac{k g h r}{k g / h r}$ & 0.80 & & 230674 & 0.57 & 514,422 & s14,969 & 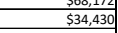 \\
\hline S/LSplit Discharge Pump to WWT & 900 GPM, 150 F T TDH & 75 & $3165 \mathrm{~s}$ & 1 & $\$ 30,000$ & 2009 & $\$ 30,000$ & strm.2200.4 & 204390 & $\mathrm{~kg} / \mathrm{hr}$ & 0.80 & & 193160 & 0.95 & 528,674 & 529,762 & 568,452 \\
\hline Flash Tank & $\begin{array}{ll}23^{\prime} \times 48^{\prime}-110,000 \text { gal. } \\
1110,000 \text { gal }\end{array}$ & & $\frac{55316}{55304}$ & $\frac{1}{1}$ & $\begin{array}{l}\$ 511,000 \\
\$ 236,000\end{array}$ & 2009 & $\frac{5511,000}{526,000}$ & 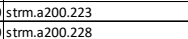 & $\frac{26416}{4401369}$ & kg/hr & $\frac{0.70}{0.70}$ & & $\frac{193160}{230674}$ & $\frac{0.73}{0.06}$ & 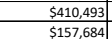 & $\begin{array}{ll}5426,067 \\
5163667]\end{array}$ & $\begin{array}{l}5852,133 \\
337,34\end{array}$ \\
\hline Ammonia Addition Tank & 118,000 gall, 1hr residence time & & & & & & & & & & & & & Area 200 Totals & $\$ 37,114,424$ & $\$ 35,786,358$ & 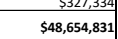 \\
\hline
\end{tabular}

\begin{tabular}{|c|c|c|c|c|c|c|c|c|c|c|c|c|c|c|c|c|c|}
\hline A300: Hydrolysis and Fermentation & \multicolumn{5}{|c|}{ Mechanical Equipment List } & \multicolumn{12}{|c|}{ Scaled Installed Costs } \\
\hline EQUIPMENT TITLE & DESCRIPTION & нР & MATERIAL & $\begin{array}{l}\text { 总 } \\
\underline{\underline{w}} \\
\frac{2}{2}\end{array}$ & \$ & 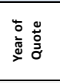 & $\begin{array}{l}\text { Purch Cost in } \\
\text { Base yr }\end{array}$ & Scaling Variable & 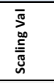 & $\frac{2}{5}$ & 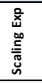 & 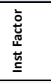 & $\begin{array}{l}\frac{\bar{m}}{3} \\
\frac{3}{2}\end{array}$ & 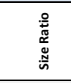 & $\begin{array}{l}\text { Scaled Purch } \\
\text { cost }\end{array}$ & $\begin{array}{l}\text { Purch cost in } \\
\text { Proj year }\end{array}$ & $\begin{array}{l}\text { Inst cost in Proj } \\
\text { year }\end{array}$ \\
\hline $\begin{array}{l}\text { atch Enzmatic Hydrolysis } \\
\text { ardollyate Cooler }\end{array}$ & Plate \& Frame $32.5 \mathrm{MMBt} / \mathrm{hr}$ & & 55304 & & $\$ 85,000$ & 2010 & 585,000 & heat.A300.EH.QC301 & & Gcal/hr & 0.70 & & & 0.80 & 572,519 & $571,321$. & \\
\hline $\begin{array}{l}\text { Enzyme-Hydrolysate Mixer } \\
\text { Saccharification Tank }\end{array}$ & $\begin{array}{l}\text { inline mixer } 1673 \mathrm{gpm} \\
50,000 \text { gal each - } 19^{\prime} \text { 'dia. x } 120^{\prime} \text { 'tall }\end{array}$ & $100 \mathrm{hp}$ & $\begin{array}{l}5316 \\
30455 \\
3\end{array}$ & $\frac{1}{8}$ & $\begin{array}{l}109,000 \\
\$ 3,840,000 \\
\end{array}$ & $\begin{array}{l}20099 \\
2009\end{array}$ & $\begin{aligned} 5 \\
\$ 3,840,000 \\
\end{aligned}$ & $\begin{array}{l}\text { strm.3300.EH.t310fd } \\
\text { strm.A300.EH.306 }\end{array}$ & $\begin{array}{l}379938 \\
421776\end{array}$ & 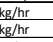 & $\frac{0.50}{0.70}$ & & 238222 & $\begin{array}{l}0.00 \\
0.56 \\
\end{array}$ & $\begin{aligned} 50 \\
2574312.146 \\
\end{aligned}$ & $\begin{aligned} 50 \\
52,671,977 \\
\end{aligned}$ & \\
\hline 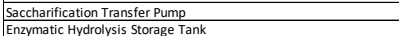 & 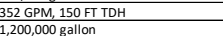 & 20 & $\begin{array}{ll}31655 \\
31655\end{array}$ & 5 & $\begin{array}{l}\$ 47,200 \\
\$ 1,3235\end{array}$ & 2009 & $\begin{aligned} \$ 47,200 \\
\$ 137,220\end{aligned}$ & 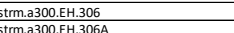 & $\begin{array}{ll}421776 \\
322989\end{array}$ & kg/hr & 0.80 & 1 & 238822 & 0.56 & $\begin{aligned} 529,886 \\
500891\end{aligned}$ & $\begin{aligned} 51,019 \\
5971000 \\
590\end{aligned}$ & \\
\hline 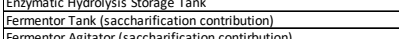 & & & $\begin{array}{l}\frac{31655}{3045} \\
3055\end{array}$ & $\frac{1}{12}$ & $\frac{\$ 1,13,725}{\frac{510,128,000}{4}}$ & $\frac{2011}{2009}$ & $\frac{S 1,17,232}{510,128,000}$ & & $\frac{328984}{12}$ & 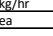 & $\frac{0.70}{1.1}$ & $\frac{1}{1.5}$ & 238222 & 0.72 & $\frac{51,050,891}{55,847,797}$ & $\begin{array}{ll}5579,944 \\
56,055,501 \\
\end{array}$ & $\begin{aligned} 1,79,59,5 \\
\$, 998,2 \\
55,9\end{aligned}$ \\
\hline 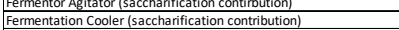 & Fate \& \& frame & $30 \mathrm{hp}$ & $\frac{5304}{3045}$ & $\frac{1}{12}$ & $\begin{aligned} 52,500 \\
88,928 \\
\end{aligned}$ & $\frac{2009}{2009}$ & $\begin{aligned} 552,50 \\
586,928\end{aligned}$ & & & $\frac{\text { ea }}{\text { ea }}$ & & 1.5 & $\frac{6.9}{6.9}$ & $\frac{6.92}{0.58}$ & $\begin{aligned} \$ 363,506 \\
55,157 \\
\end{aligned}$ & $\begin{aligned} \$ 577,797 \\
52,060\end{aligned}$ & $\begin{array}{c}5565,4 \\
514,4 \\
\end{array}$ \\
\hline 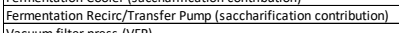 & 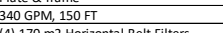 & 20 & 31555 & $\frac{15}{5}$ & $\begin{array}{ll}\frac{547,200}{54200} \\
52,500\end{array}$ & 2009 & $\$ 547,200$ & & & ea & 0.8 & 2.3 .3 & 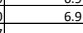 & 0.58 & $\begin{array}{ll}530,400 \\
530,400\end{array}$ & 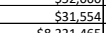 & $\$ 13.976$ \\
\hline 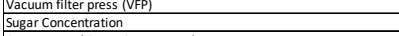 & 4) $170 \mathrm{~m} 2$ Horizontal Belt Filiters & $3600 \mathrm{kw}$ & $\frac{3045 s}{30455}$ & $\frac{4}{1}$ & $\frac{52,153,300}{56,370,000}$ & 2013 & $56,370,006$ & & & & 0.7 & & 2040622 & $\frac{1.00}{0.84}$ & 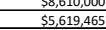 & \begin{tabular}{c|c|}
$58,212,465$, \\
$55,365,881$
\end{tabular} & $\begin{array}{l}\frac{513,96}{\$ 10,731} \\
\end{array}$ \\
\hline Concentrated Sugar Storage Tank & 5,500 gallons - 20 min residence time & $20 \mathrm{hp}$ & ss & 1 & $\$ 168,000$ & 2011 & $\$ 168,000$ & & & & $0.77>3$ & & & & $\frac{5122,849}{\$ 2436783}$ & 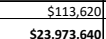 & \\
\hline
\end{tabular}

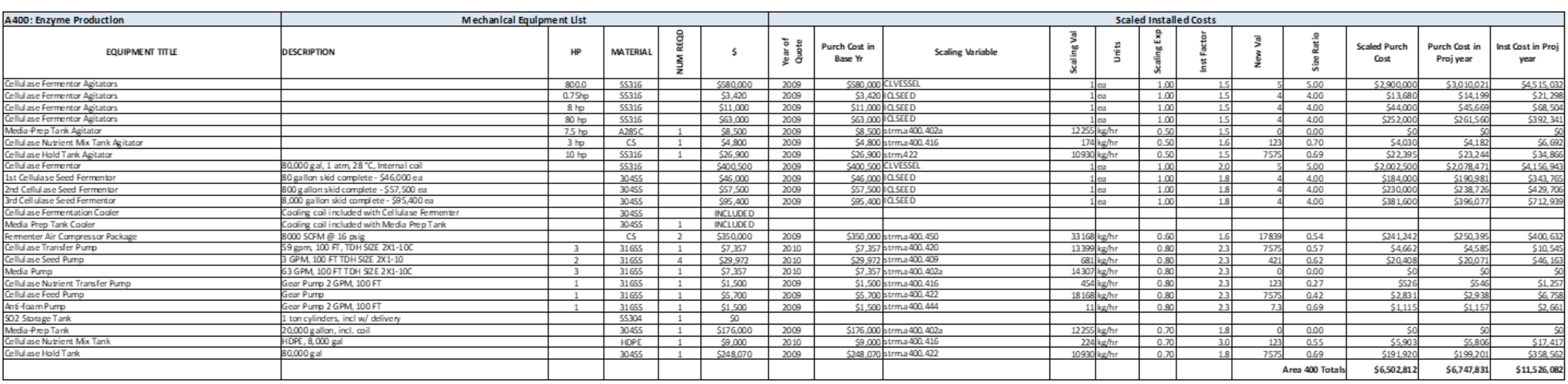




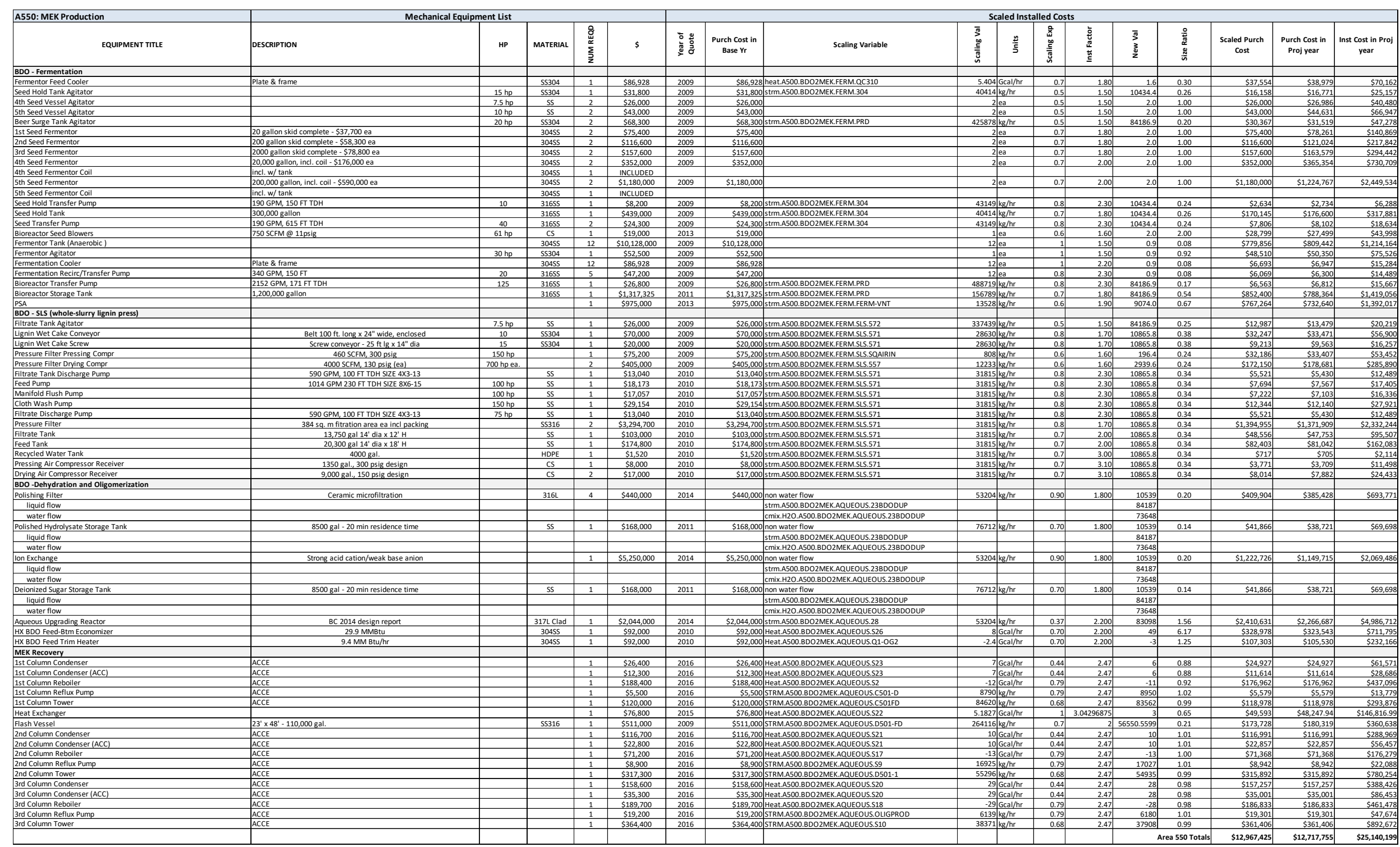




\begin{tabular}{|c|c|c|c|c|c|c|c|c|c|c|c|c|c|c|c|c|c|}
\hline A500: Furans Production \& Upgrading & Mechanical Equipm & nt list & & & & & & & & led Inst & led cos & & & & & & \\
\hline EQUIPMENT TITLE & DESCRIPTION & HP & MATERIAL & 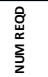 & $\$$ & 童高 & $\begin{array}{c}\text { Purch cost in } \\
\text { Base } \mathrm{Yr}\end{array}$ & scaling Variable & 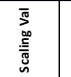 & $\frac{a}{5}$ & 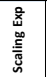 & 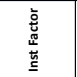 & $\begin{array}{l}\text { 㚅 } \\
\frac{3}{2}\end{array}$ & 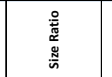 & $\begin{array}{l}\text { Scaled Purch } \\
\text { cost }\end{array}$ & $\begin{array}{l}\text { Purch Cost in } \\
\text { Proj year }\end{array}$ & $\begin{array}{c}\text { Inst cost in Proj } \\
\text { year }\end{array}$ \\
\hline 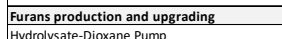 & & & & & & & & STRMASO0.FURANS 5 & & & & & & & & & \\
\hline 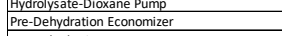 & 2-4 TEMA shell and tube HX & & 31655 & $\frac{1}{1}$ & $\frac{595,600}{\$ 353,600}$ & 2002 & 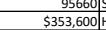 & 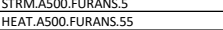 & $\frac{39928816 \mathrm{M}}{14.3 \mathrm{~N}}$ & blikral/h & $\frac{0.33}{0.7}$ & 2.65825779 & $\begin{array}{lll}44393 \\
42 \\
42\end{array}$ & $\frac{1.27}{2.92}$ & $\begin{array}{l}5130,541 \\
\$ 778,605\end{array}$ & 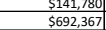 & $\begin{array}{c}\$ 350,197] \\
\$ 1,838,805\end{array}$ \\
\hline & & & & $\frac{1}{1}$ & $\begin{array}{ll}\frac{576,800}{54903} \\
54,34\end{array}$ & $\frac{2015}{2013}$ & $\frac{576,800}{54912345}$ & 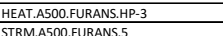 & 5.18276 & 6cal/hr & & $\begin{array}{ll}3.04296875 \\
.17\end{array}$ & & 2.77 & 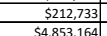 & $\frac{5206,964}{543460}$ & $\frac{5629,785}{5578072}$ \\
\hline Sugar Dehydration Reactor & Tubular flow reactor, $5 \mathrm{~min}$ RT & & & 1 & $\frac{\$ 4,913,234}{5}$ & $\frac{2013}{\min }$ & $\$ 4,913,234$ & 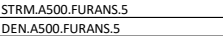 & & & & & & & $\$ 4,853,164$ & $\$ 4,634,160$ & 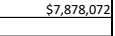 \\
\hline $\begin{array}{l}\text { Post-Dehydration Cooler } \\
\text { PAldo Condensation reactor }\end{array}$ & Sth seed fermentor (Humbird, 2009 & & & $\frac{1}{1}$ & 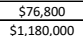 & $\frac{2015}{2009}$ & 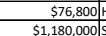 & 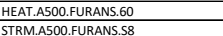 & & ccal/hr & $\frac{1}{0.7}$ & $\frac{3.0429675}{2}$ & $\begin{aligned} 2063.389 \\
\end{aligned}$ & $\frac{3.92}{0.26}$ & $\frac{5301,097 \mid}{5446,911}$ & $\frac{5292,931}{5 \$ 842549}$ & $\begin{array}{c}5891,3807 \\
59655097\end{array}$ \\
\hline & ACE & & & & & & & 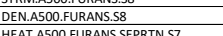 & & & & & & & & & \\
\hline $\begin{array}{l}\text { Dioxane Column Condenser } \\
\text { Dioxane Columm Condenser (ACC) } \\
\end{array}$ & $\begin{array}{ccc}A C C E \\
C C E\end{array}$ & & & $\frac{1}{1}$ & $\frac{5576,100}{539,500}$ & $\frac{2016}{2016}$ & $\begin{array}{l}\$ 267,1,000 \\
539,500 \\
\end{array}$ & 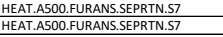 & $\begin{aligned} 5886 \\
586\end{aligned}$ & 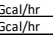 & $\begin{array}{l}0.44 \\
0.44\end{array}$ & 2.47 & $\frac{30}{30}$ & 0.52 & $\begin{array}{lll}\frac{5202,677}{529,677} \\
5\end{array}$ & 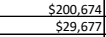 & $\begin{array}{ll}5495,664 \\
573,301 \\
\end{array}$ \\
\hline $\begin{array}{l}\text { Dioixane CClumn neebolier } \\
\text { Dixona e columm Reflux Pump }\end{array}$ & & & & & $\frac{5254,200}{552300}$ & 2016 & 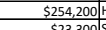 & 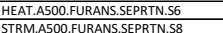 & & & 0.79 & & & 0.53 & $\frac{\$ 153,409}{51570}$ & $\begin{array}{l}\$ 153,409 \\
5,450 \\
\end{array}$ & $\frac{5378,920}{53509}$ \\
\hline $\begin{array}{l}\text { Dioxane Columnn Reflux Pump } \\
\text { Dioxane Column Tow }\end{array}$ & CCCE & & & $\frac{1}{1}$ & $\frac{\$ 523,300}{\$ 568,600}$ & $\frac{2016}{2016}$ & 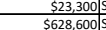 & 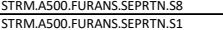 & $\frac{277694 \mathrm{KG}}{373388 \mathrm{Kg}_{\mathrm{K}}}$ & $\mathrm{ggh/hr}$ & 0.79 & & $\frac{151622}{208246}$ & $\frac{0.55}{0.56}$ & $\frac{514,574}{542,608}$ & $\frac{\$ 14,544}{\$ 422.608}$ & $\frac{535,98}{51.043842}$ \\
\hline Hydrocarbon Decanter & CCE & & & 1 & $\frac{5020,100}{\$ 32,100}$ & 2016 & 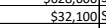 & 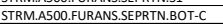 & $98695 \mathrm{~kg}$ & gg/hr & 0.60 & $\frac{2.47}{2.47} \mathrm{rar} \mathrm{l}$ & 57872 & 0.59 & $\frac{542,0003}{522,303}$ & $\$ 22,303$ & 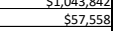 \\
\hline $\begin{array}{l}\text { Dioxane Recycle Cooler } \\
\text { Hydrocarbon unmp }\end{array}$ & 1906 GPM, $615 \mathrm{~F} \mathrm{~T} \mathrm{TH}$ & 40 & 31655 & $\frac{1}{2}$ & $\begin{array}{ll}\$ 57,8,800 \\
524,300 \\
\end{array}$ & $\frac{2015}{2009}$ & $\begin{array}{ll}576,800 \mid \\
524,300 \mid\end{array}$ & 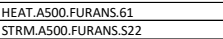 & $\begin{array}{lll}5.1827 \mathrm{G} \\
434149 \mathrm{~kg}\end{array}$ & ccal/hr & $\frac{1}{0.8}$ & $\frac{3.04296875}{2.3}$ & $\frac{4}{19228}$ & $\frac{0.76}{0.45}$ & $\begin{array}{lll}\$ 58,345 \\
55.458\end{array}$ & $\begin{array}{ccc}556,764 \\
52,6233\end{array}$ & $\begin{array}{ll}5172,731 \\
56,0744 \\
\end{array}$ \\
\hline Pre-Hydrotreating Economizer & 2-4 TEMA shell and tube HX & & 31655 & 1 & & 2011 & $\$ 3353,600+$ & HEAT.ASOO.FURANS. 47 & $-14.3 \mathrm{~N}$ & 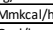 & 0.7 & 2.66 & -3.3 & 0.23 & $\$ 127,081$ & $\$ 117,534$ & $\$ 312,150$ \\
\hline $\begin{array}{l}\text { Preve-Dhydration Heater } \\
\text { Fresh H2 compressoror }\end{array}$ & Reciprocating compressor 5 stapes) & & & 1 & $\frac{\$ 76,800}{\$ 11221200}$ & $\frac{2015}{2011}$ & 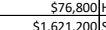 & 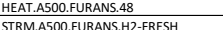 & $\begin{aligned} 5.1827 / 6 \\
3896519 \mathrm{~kg}\end{aligned}$ & Gcal/hr & $\frac{1}{0.6}$ & $\frac{3.04296875}{1099}$ & $\begin{array}{l}1.0525161 \\
1096559025\end{array}$ & $\frac{0.20}{5.10}$ & $\frac{\$ 15,596,744}{5 \$ 303144}$ & 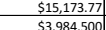 & 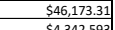 \\
\hline Fresh Hz compresessor (spare) & 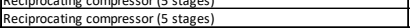 & & & & 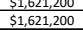 & & 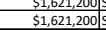 & 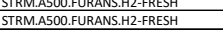 & $389.56519 \mathrm{kik}$ & $\mathrm{kg} / \mathrm{hr}$ & & $\begin{array}{l}1.09 \\
1.08 \\
\end{array}$ & $\begin{array}{l}1968.54942 \\
196659462 \\
\end{array}$ & 5.10 & $\frac{54,038,844}{54,308,144}$ & $\begin{array}{l}\$ 3,398,4000 \\
\$ 3,98,500\end{array}$ & 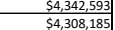 \\
\hline 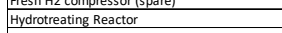 & 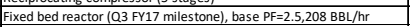 & & & 1 & $\frac{31,62,100}{56,513,387}$ & $\frac{2011}{2011}$ & 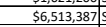 & 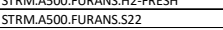 & 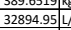 & /l/hr & $\frac{0.7}{0.7}$ & $\frac{1.08}{2.00}$ & 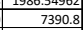 & 0.22 & 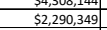 & 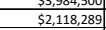 & $\frac{54,308,185}{\$ 4,236,579}$ \\
\hline \begin{tabular}{|l} 
Pressure foctor (via Guthrie) \\
Flash vessel
\end{tabular} & 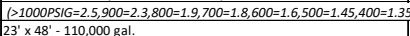 & & $\$ 5316$ & 1 & 5511,000 & 2009 & 5511,000 & 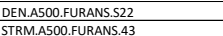 & $264116 \mathrm{~kg}$ & kg/hr & $0.7 \mathrm{Y}>\mathrm{C}$ & $2.00 \mathrm{C}-2 \mathrm{c}$ & 22162.117 & 0.08 & $590,176 \mathrm{~F}$ & 593,597 & 5187,195 \\
\hline SSA unit & Hz recovery & & & & 5995,000 & 2013 & $5975,000 \mid$ & 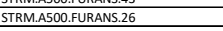 & $213528 \mathrm{~kg}$ & eg/hr & 0.6 & $\frac{2.00}{1.90}$ & 10922.5275 & 0.08 & $\frac{53,110}{5215,439}$ & $\frac{5350317}{5205,717}$ & 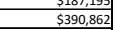 \\
\hline $\begin{array}{l}\text { Recycle H2 compressoror } \\
\text { Recycle H2 } 20 \text { pressor (spare) }\end{array}$ & $\begin{array}{l}\text { Centrifífal compressor } \\
\text { Centifual compressor }\end{array}$ & & & $\frac{1}{1}$ & $\begin{array}{ll}\$ 1,103,00 \\
\$, 103,700\end{array}$ & $\frac{2011}{2011}$ & $\begin{array}{ll}1,1,13,700 \mid \\
\$ 1,103,000 \mid\end{array}$ & 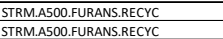 & 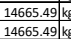 & 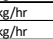 & $\begin{array}{c}0.6 \\
0.6\end{array}$ & $\frac{1.13}{1.10}$ & $\begin{array}{l}947.799615 \\
947.09715 \\
\end{array}$ & $\begin{array}{cc}0.06 \\
0.06\end{array}$ & $\begin{array}{ll}5213,258 \\
5312,258\end{array}$ & 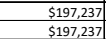 & 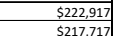 \\
\hline $\begin{array}{l}\text { Air compressor } \\
\text { Octors }\end{array}$ & & & & 2 & 534,600 & 2011 & $\begin{array}{l}534,600 \mid \\
53,00\end{array}$ & STRMASOSO0.FUUANS.44 & $818.9219 \mathrm{~kg}$ & & 0.6 & 1.82 & 2257.5985 & 0.59 & 550,480 & 546,688 & $\begin{array}{l}321,1010 \\
585,010 \\
\end{array}$ \\
\hline $\begin{array}{l}\text { Offf-gas b bilier } \\
\text { Flash Vessel }\end{array}$ & 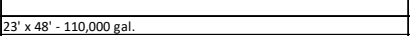 & & 55316 & $\frac{1}{1}$ & $\frac{5241,400}{\$ 551,000}$ & $\frac{2011}{2009}$ & $\frac{524,1,000 \mid}{5511,000 \mid}$ & 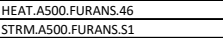 & 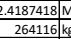 & $\begin{array}{l}\text { Munkcal } \\
\text { ughr }\end{array}$ & 0.7 .7 & & 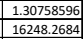 & 0.04 & $\begin{array}{ll}515,9497 \\
572,565 \\
\end{array}$ & $\begin{array}{l}5145,1,57 \\
57,318 \\
\end{array}$ & 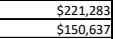 \\
\hline & & & & & & & & & & & & & & Area 500 Totals & $\$ 19,673,536$ & $\$ 18,559,130$ & $\$ 29,593,424$ \\
\hline
\end{tabular}

\begin{tabular}{|c|c|c|c|c|c|c|c|c|c|c|c|c|c|c|c|c|c|}
\hline A600:WWT & Mechanical Equipment List & & & & & \multicolumn{12}{|c|}{ Scaled Installed Costs } \\
\hline EQUIPMENT TITLE & DESCRIPTION & HP & MATERIAL & 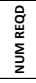 & s & 范 & $\begin{array}{c}\text { Purch cost in } \\
\text { Base } \mathrm{Yr}\end{array}$ & scaling Variable & 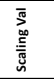 & $\frac{2}{5}$ & 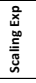 & 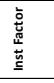 & $\begin{array}{l}\frac{\bar{a}}{3} \\
\frac{3}{2}\end{array}$ & 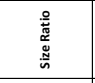 & $\begin{array}{l}\text { Scaled Purch } \\
\text { cost }\end{array}$ & $\begin{array}{l}\text { Purch cost in } \\
\text { Proj year }\end{array}$ & $\begin{array}{c}\text { Inst coss tin Proj } \\
\text { year }\end{array}$ \\
\hline $\begin{array}{l}\text { Aertatio Basin } \\
\text { Pump - Centrifual, Aeration Basin Feed }\end{array}$ & $\begin{array}{l}\text { C.concete and steel, not installed cost } \\
552 \text { gepmea }\end{array}$ & & $\frac{c_{\text {Concrete }}}{c \mathrm{cs}}$ & $\frac{3}{4}$ & $\frac{\$ 4,804,854}{\$ \$ 4,800}$ & $\frac{2012}{2012}$ & $\$ 4,80,85$. & Hydraulic flow & & MGD & 0.6. & & 1. & & $\$ 3,872,991$ & & $\$ 7,428,765$ \\
\hline & $\begin{array}{l}82 \text { gmea } \\
\text { Full floor aeration grid }\end{array}$ & $45 \mathrm{hp}$ & $\frac{\mathrm{cs}}{\mathrm{cs}}$ & & $\begin{array}{l}564,800 \\
\$ 2,500,000 \\
\end{array}$ & $\frac{2012}{2012}$ & & & & & & & & & & & \\
\hline $\begin{array}{l}\text { Caustic Feed System } \\
\text { Blowers }\end{array}$ & & $1.5 \mathrm{hp}$ & cs & 4 & $\begin{aligned} 520,000 \\
520000\end{aligned}$ & $\frac{2012}{2012}$ & 520,00 & $\frac{C O D}{C O D}$ & 5600 & $\mathrm{~kg} / \mathrm{hr}$ & 0.6 & & 675 & 1.21 & & 520,745 & \\
\hline $\begin{array}{l}\text { Blowers } \\
\text { Membrane Bioreactor }\end{array}$ & 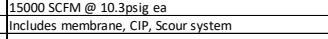 & 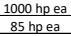 & $\frac{\mathrm{cs}}{\mathrm{cs}}$ & $\frac{9}{1}$ & $\begin{array}{l}\$ 2,0,0,0,000 \\
\$ \$, 898,500 \\
\end{array}$ & $\frac{2012}{2012}$ & $\begin{array}{ll}\frac{\$ 2,70,000}{\$ 5,898,50} \\
\end{array}$ & $\begin{array}{ccc}\text { CoD } \\
\text { Hydraulic fllow }\end{array}$ & $\begin{array}{r}5600 \\
2.7 \\
\end{array}$ & gG/hr & $\frac{0.66}{1.00}$ & $\frac{2.6}{1.6}$ & $\frac{675 .}{1 .}$ & $\frac{1.21}{0.70}$ & $\begin{array}{l}\$ 25,371,180 \\
53,41,849 \\
\end{array}$ & $\begin{array}{l}\$ 2,1,177,1,37 \\
\$ 3,168,89 \\
\end{array}$ & 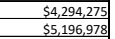 \\
\hline $\begin{array}{l}\text { Pump, Centififugal, MBR, RAS } \\
\text { Gravity Belt Thickeners }\end{array}$ & & $160 \mathrm{hp}$ & $\frac{c s}{c s}$ & $\frac{6}{3}$ & 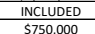 & 2012 & & & & & & & & & & & \\
\hline & mem presses & $\frac{48 \mathrm{hp}}{165 \mathrm{hp} \text { ea }}$ & $\frac{\mathrm{cs}}{\mathrm{cs}}$ & $\frac{3}{1}$ & $\frac{5750,000}{5686,800}$ & $\frac{2012}{2012}$ & $\frac{5550,00}{5686,80}$ & $\frac{c o 0}{c o 0}$ & $\frac{560}{5600}$ & 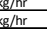 & $\frac{0.66}{0.66}$ & & $\frac{675}{675}$ & $\frac{1.21}{1.21}$ & $\frac{5839,588}{5768,811}$ & $\frac{577,7948}{5712,393}$ & $\frac{51,263,98}{51,96,38}$ \\
\hline 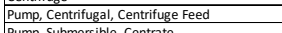 & $\frac{105 \mathrm{gpm}}{100 \mathrm{pmm}}$ & $15 \mathrm{hp}$ & $\frac{\operatorname{cs}}{\operatorname{cs}}$ & $\frac{2}{2}$ & $\begin{array}{l}\text { INCLUDED } \\
\text { INULED }\end{array}$ & $\frac{2012}{2012}$ & & & & & & & & & & & \\
\hline $\begin{array}{l}\text { Pump, Submersible, Centrate } \\
\text { Dewatering Polymer Addition }\end{array}$ & $\begin{array}{l}100 \mathrm{gpm} \\
9.8 \mathrm{gph} \text { neat polymer }\end{array}$ & $\begin{array}{l}10 \text { hpea } \\
11 \text { p ea } \\
\end{array}$ & $\frac{c s}{c s}$ & $\frac{2}{2}$ & $\begin{array}{l}\text { IICLCLDED } \\
\text { INCLUDED }\end{array}$ & $\frac{2012}{2012}$ & 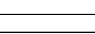 & & & & - & & & & & & \\
\hline $\begin{array}{l}\text { Conveyor } \\
\text { Revere esmosis }\end{array}$ & & 10 hpea & $\frac{c s}{c s}$ & 1 & 57,000 & 2012 & $\frac{57,00}{20500}$ & COD & 5600 & $\mathrm{~kg} / \mathrm{hr}$ & 0.6. & 2.5 & 675. & 1.21 & 57,836 & 57,261 & $\frac{520}{52723}$ \\
\hline & $368 \mathrm{gpm}$ & 1480 hp ea & $\frac{\text { Titanium }}{\text { Titan }}$ & & $\begin{array}{l}\frac{25,450,000}{\$ 5,000,000} \\
\end{array}$ & & & 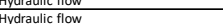 & & & & & & & & & $\frac{\$ 2,773}{\$ 6,12}$ \\
\hline 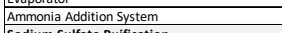 & 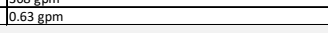 & $4.5 \mathrm{hp}$ & cs & $\frac{4}{4}$ & $\begin{array}{l}\$ 30,000,200 \\
\$ 195,200 \\
\end{array}$ & $\frac{2012}{2012}$ & 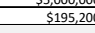 & COD & $\frac{5600}{5600}$ & eg/hr & 0.65 & & 675. & 1.21 & $\begin{array}{ll}\frac{3445030,50}{5218,509} \\
\end{array}$ & $\$ 202,474$ & 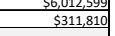 \\
\hline $\begin{array}{l}\text { Sodium Sultate eutifitation } \\
\text { Evaporator feed tank }\end{array}$ & |insulated, 6460 gal & & & & $\$ 45,966$ & & $545,96$. & strm.6600.23 & 290932 & & 0.66 & & 135185. & 4.65 & $\$ 115,537$ & \$106,857] & \\
\hline Evaporator feed heater & shell and tube $1 / 2$ pass & & & & $\$ 274,818$ & 2011 & $5274,81$. & heat $A 600.31$ & -13 & Minkall & 0.66 & 3.06 & $\ldots$ & 0.56 & 5193,611 & 5179,067 & $\frac{350,145}{5537,200}$ \\
\hline & 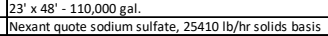 & & 55316 & $\frac{1}{1}$ & 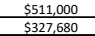 & $\frac{2009}{2011}$ & 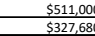 & 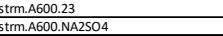 & $\frac{264116}{111524}$ & gk/hr & $\frac{0.7}{0.65}$ & & $\frac{135185}{1064}$ & $\frac{5.12}{1.27}$ & 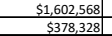 & $\begin{array}{llll}\frac{51,6,63,366}{5349,907} \\
\end{array}$ & $\begin{array}{l}\frac{\$ 3,326,733}{\$ 804,786} \\
\end{array}$ \\
\hline C & Nexant quote Sodium sulfate, $25410 \mathrm{lb} / \mathrm{b}$. $\mathrm{r}$ solids basis & & & 1 & 5555,008 & 2011 & $\begin{array}{ll}5555,000 \\
550\end{array}$ & $\begin{array}{l}\text { Strm.A600.PRDD-SALT } \\
\text { Strate }\end{array}$ & 11524 & gghr & 0.60 & & $\frac{1394}{1394}$ & 1.21 & $\begin{array}{l}362,307 \\
562,307\end{array}$ & 5575,557 & $\frac{51,496,44}{\$ 5,40}$ \\
\hline & & & & & & & & & & & & & & Area 600 Totals & $\$ 20,120,213$ & $\$ 18,819,842$ & $\$_{33,686,64}$ \\
\hline
\end{tabular}




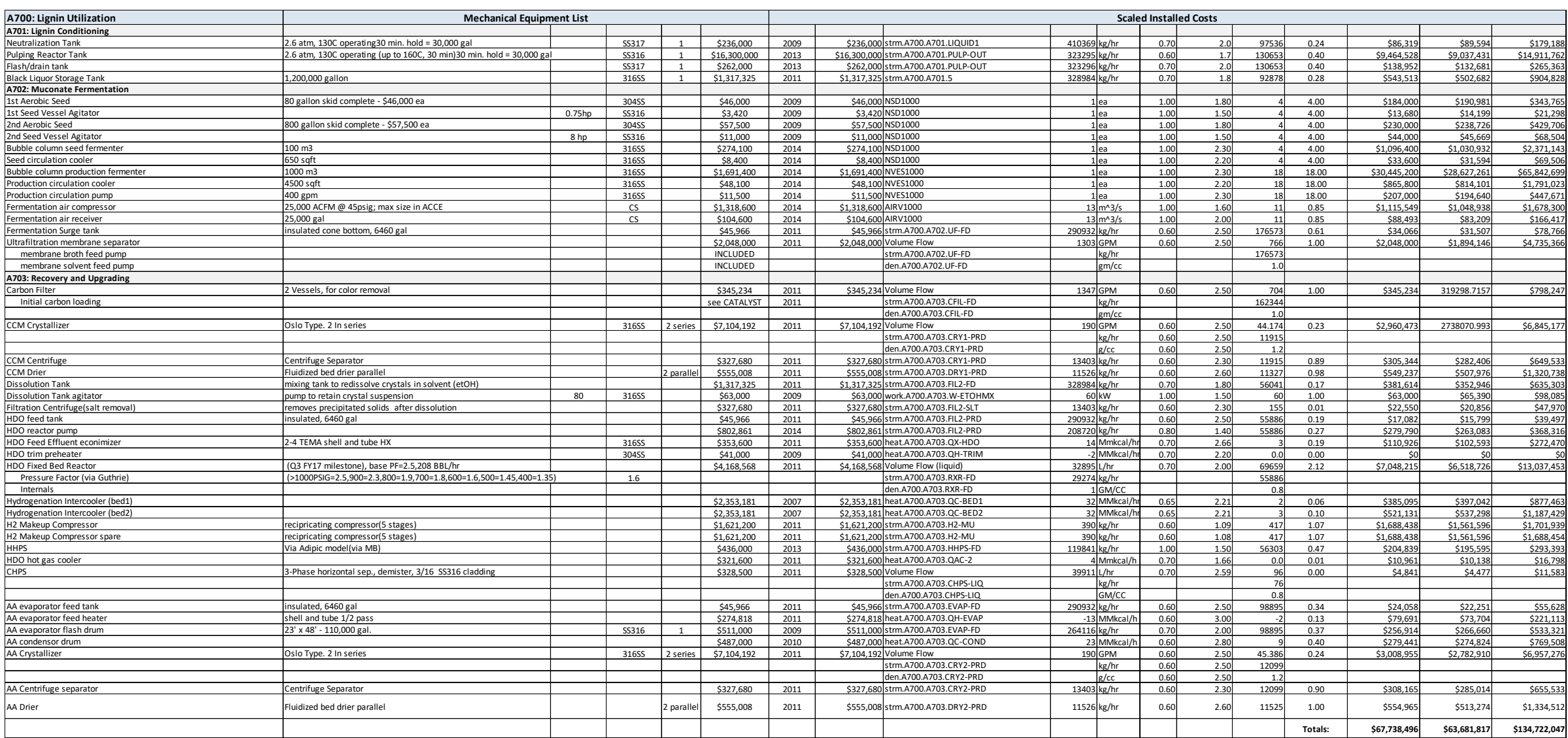



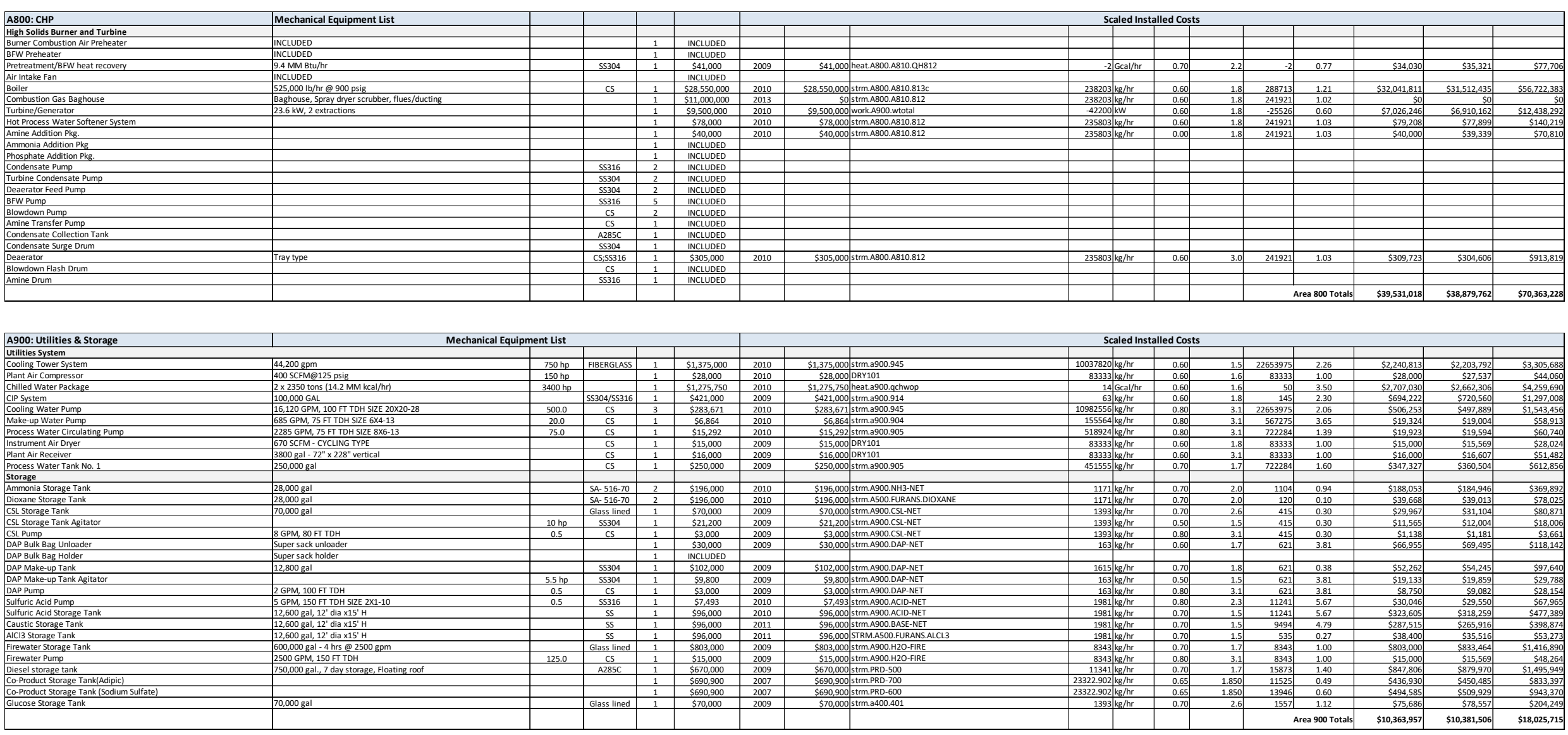


\section{Appendix B. Discounted Cash Flow Rate of Return Worksheet}

\section{Dedicated Biorefinery}

\begin{tabular}{|c|c|c|c|c|c|c|c|c|}
\hline Year & -2 & -1 & $\mathbf{0}$ & 1 & 2 & 3 & 4 & 5 \\
\hline Fixed Capital Investment & $\$ 23,923,976$ & $\$ 179,429,817$ & $\$ 95,695,902$ & & & & & \\
\hline Land & $\$ 1,848,000$ & & & & & & & \\
\hline Working Capital & & & $\$ 37,381,212$ & & & & & \\
\hline Loan Payment & & & & $\$ 66,850,835$ & $\$ 66,850,835$ & $\$ 66,850,835$ & $\$ 66,850,835$ & $\$ 66,850,835$ \\
\hline Loan Interest Payment & $\$ 2,870,877$ & $\$ 24,402,455$ & $\$ 35,885,963$ & $\$ 35,885,963$ & $\$ 33,408,774$ & $\$ 30,733,409$ & $\$ 27,844,015$ & $\$ 24,723,469$ \\
\hline Loan Principal & $\$ 35,885,963$ & $\$ 305,030,688$ & $\$ 448,574,541$ & $\$ 417,609,670$ & $\$ 384,167,609$ & $\$ 348,050,183$ & $\$ 309,043,363$ & $\$ 266,915,998$ \\
\hline Fuel Sales & & & & $\$ 149,571,091$ & $\$ 199,428,121$ & $\$ 199,428,121$ & $\$ 199,428,121$ & $\$ 199,428,121$ \\
\hline By-Product Credit & & & & $\$ 144,419,846$ & $\$ 192,559,795$ & $\$ 192,559,795$ & $\$ 192,559,795$ & $\$ 192,559,795$ \\
\hline Total Annual Sales & & & & $\$ 293,990,937$ & $\$ 391,987,916$ & $\$ 391,987,916$ & $\$ 391,987,916$ & $\$ 391,987,916$ \\
\hline \multicolumn{9}{|l|}{ Annual Manufacturing Cost } \\
\hline Feedstock & & & & $\$ 38,712,485$ & $\$ 51,616,647$ & $\$ 51,616,647$ & $\$ 51,616,647$ & $\$ 51,616,647$ \\
\hline Periodic Costs (Catalyst, etc) & & & & $\$ 16,174,947$ & $\$ 0$ & $\$ 1,506,720$ & $\$ 238,632$ & $\$ 1,506,720$ \\
\hline Other Variable Costs & & & & $\$ 188,725,096$ & $\$ 215,685,824$ & $\$ 215,685,824$ & $\$ 215,685,824$ & $\$ 215,685,824$ \\
\hline Fixed Operating Costs & & & & $\$ 20,426,101$ & $\$ 20,426,101$ & $\$ 20,426,101$ & $\$ 20,426,101$ & $\$ 20,426,101$ \\
\hline Total Product Cost & & & & $\$ 264,038,630$ & $\$ 287,728,572$ & $\$ 289,235,292$ & $\$ 287,967,204$ & $\$ 289,235,292$ \\
\hline \multicolumn{9}{|l|}{ Annual Depreciation } \\
\hline General Plant Writedown & & & & $14 \%$ & $24.49 \%$ & $17.49 \%$ & $12.49 \%$ & $8.93 \%$ \\
\hline Depreciation Charge & & & & $\$ 98,249,621$ & $\$ 168,378,811$ & $\$ 120,250,936$ & $\$ 85,873,881$ & $\$ 61,397,419$ \\
\hline Remaining Value & & & & $\$ 589,291,463$ & $\$ 420,912,652$ & $\$ 300,661,716$ & $\$ 214,787,835$ & $\$ 153,390,416$ \\
\hline Steam Plant Writedown & & & & $3.75 \%$ & $7.22 \%$ & $6.68 \%$ & $6.18 \%$ & $5.71 \%$ \\
\hline Depreciation Charge & & & & $\$ 2,253,118$ & $\$ 4,337,403$ & $\$ 4,011,752$ & $\$ 3,711,336$ & $\$ 3,432,550$ \\
\hline Remaining Value & & & & $\$ 57,830,033$ & $\$ 53,492,630$ & $\$ 49,480,878$ & $\$ 45,769,542$ & $\$ 42,336,992$ \\
\hline Net Revenue & & & & $(\$ 106,436,395)$ & $(\$ 101,865,644)$ & $(\$ 52,243,472)$ & $(\$ 13,408,520)$ & $\$ 13,199,186$ \\
\hline Losses Forward & & & & & $(\$ 106,436,395)$ & $(\$ 208,302,039)$ & $(\$ 260,545,511)$ & $(\$ 273,954,032)$ \\
\hline Taxable Income & & & & $(\$ 106,436,395)$ & $(\$ 208,302,039)$ & $(\$ 260,545,511)$ & $(\$ 273,954,032)$ & $(\$ 260,754,846)$ \\
\hline Income Tax & & & & $\$ 0$ & $\$ 0$ & $\$ 0$ & $\$ 0$ & $\$ 0$ \\
\hline Annual Cash Income & & & & $-\$ 36,898,527$ & $\$ 37,408,509$ & $\$ 35,901,790$ & $\$ 37,169,877$ & $\$ 35,901,790$ \\
\hline Discount Factor & 1.2100 & 1.1000 & 1.0000 & 0.9091 & 0.8264 & 0.7513 & 0.6830 & 0.6209 \\
\hline Annual Present Value $\quad \$ 425,588,258$ & & & & $-\$ 33,544,116$ & $\$ 30,916,123$ & $\$ 26,973,546$ & $\$ 25,387,526$ & $\$ 22,292,187$ \\
\hline Total Capital Investment + Interest & $\$ 34,657,852$ & $\$ 224,215,499$ & $\$ 168,963,077$ & & & & & \\
\hline
\end{tabular}

Net Present Worth

DCFROR Worksheet

\begin{tabular}{|c|c|c|c|c|c|c|c|c|}
\hline Year & 6 & 7 & 8 & 9 & 10 & 11 & 12 & 13 \\
\hline \multicolumn{9}{|l|}{$\begin{array}{l}\text { Fixed Capital Investment } \\
\text { Land } \\
\text { Working Capital }\end{array}$} \\
\hline Loan Payment & $\$ 66,850,835$ & $\$ 66,850,835$ & $\$ 66,850,835$ & $\$ 66,850,835$ & $\$ 66,850,835$ & $\$ 0$ & $\$ 0$ & $\$ 0$ \\
\hline Loan Interest Payment & $\$ 21,353,280$ & $\$ 17,713,475$ & $\$ 13,782,487$ & $\$ 9,537,019$ & $\$ 4,951,914$ & $\$ 0$ & $\$ 0$ & $\$ 0$ \\
\hline Loan Principal & $\$ 221,418,443$ & $\$ 172,281,084$ & $\$ 119,212,736$ & $\$ 61,898,921$ & $\$ 0$ & $\$ 0$ & $\$ 0$ & $\$ 0$ \\
\hline Fuel Sales & $\$ 199,428,121$ & $\$ 199,428,121$ & $\$ 199,428,121$ & $\$ 199,428,121$ & $\$ 199,428,121$ & $\$ 199,428,121$ & $\$ 199,428,121$ & $\$ 199,428,121$ \\
\hline By-Product Credit & $\$ 192,559,795$ & $\$ 192,559,795$ & $\$ 192,559,795$ & $\$ 192,559,795$ & $\$ 192,559,795$ & $\$ 192,559,795$ & $\$ 192,559,795$ & $\$ 192,559,795$ \\
\hline Total Annual Sales & $\$ 391,987,916$ & $\$ 391,987,916$ & $\$ 391,987,916$ & $\$ 391,987,916$ & $\$ 391,987,916$ & $\$ 391,987,916$ & $\$ 391,987,916$ & $\$ 391,987,916$ \\
\hline \multicolumn{9}{|l|}{ Annual Manufacturing Cost } \\
\hline Feedstock & $\$ 51,616,647$ & $\$ 51,616,647$ & $\$ 51,616,647$ & $\$ 51,616,647$ & $\$ 51,616,647$ & $\$ 51,616,647$ & $\$ 51,616,647$ & $\$ 51,616,647$ \\
\hline Periodic Costs (Catalyst, etc) & $\$ 511,169$ & $\$ 1,745,352$ & $\$ 0$ & $\$ 1,506,720$ & $\$ 238,632$ & $\$ 2,017,888$ & $\$ 0$ & $\$ 1,745,352$ \\
\hline Other Variable Costs & $\$ 215,685,824$ & $\$ 215,685,824$ & $\$ 215,685,824$ & $\$ 215,685,824$ & $\$ 215,685,824$ & $\$ 215,685,824$ & $\$ 215,685,824$ & $\$ 215,685,824$ \\
\hline Fixed Operating Costs & $\$ 20,426,101$ & $\$ 20,426,101$ & $\$ 20,426,101$ & $\$ 20,426,101$ & $\$ 20,426,101$ & $\$ 20,426,101$ & $\$ 20,426,101$ & $\$ 20,426,101$ \\
\hline Total Product Cost & $\$ 288,239,741$ & $\$ 289,473,924$ & $\$ 287,728,572$ & $\$ 289,235,292$ & $\$ 287,967,204$ & $\$ 289,746,460$ & $\$ 287,728,572$ & $\$ 289,473,924$ \\
\hline \multicolumn{9}{|l|}{ Annual Depreciation } \\
\hline General Plant Writedown & $8.92 \%$ & $8.93 \%$ & $4.46 \%$ & & & & & \\
\hline Depreciation Charge & $\$ 61,328,665$ & $\$ 61,397,419$ & $\$ 30,664,332$ & & & & & \\
\hline Remaining Value & $\$ 92,061,751$ & $\$ 30,664,332$ & $\$ 0$ & & & & & \\
\hline Steam Plant Writedown & $5.29 \%$ & $4.89 \%$ & $4.52 \%$ & $4.46 \%$ & $4.46 \%$ & $4.46 \%$ & $4.46 \%$ & $4.46 \%$ \\
\hline Depreciation Charge & $\$ 3,175,395$ & $\$ 2,936,864$ & $\$ 2,716,960$ & $\$ 2,680,910$ & $\$ 2,680,309$ & $\$ 2,680,910$ & $\$ 2,680,309$ & $\$ 2,680,910$ \\
\hline Remaining Value & $\$ 39,161,597$ & $\$ 36,224,733$ & $\$ 33,507,773$ & $\$ 30,826,862$ & $\$ 28,146,553$ & $\$ 25,465,643$ & $\$ 22,785,333$ & $\$ 20,104,423$ \\
\hline Net Revenue & $\$ 17,890,836$ & $\$ 20,466,233$ & $\$ 57,095,565$ & $\$ 90,534,695$ & $\$ 96,388,489$ & $\$ 99,560,545$ & $\$ 101,579,035$ & $\$ 99,833,082$ \\
\hline Losses Forward & $(\$ 260,754,846)$ & $(\$ 242,864,010)$ & $(\$ 222,397,776)$ & $(\$ 165,302,212)$ & $-\$ 74,767,517$ & $\$ 0$ & $\$ 0$ & $\$ 0$ \\
\hline Taxable Income & $(\$ 242,864,010)$ & $(\$ 222,397,776)$ & $(\$ 165,302,212)$ & $-\$ 74,767,517$ & $\$ 21,620,972$ & $\$ 99,560,545$ & $\$ 101,579,035$ & $\$ 99,833,082$ \\
\hline Income Tax & $\$ 0$ & $\$ 0$ & $\$ 0$ & $\$ 0$ & $\$ 4,540,404$ & $\$ 20,907,715$ & $\$ 21,331,597$ & $\$ 20,964,947$ \\
\hline Annual Cash Income & $\$ 36,897,341$ & $\$ 35,663,158$ & $\$ 37,408,509$ & $\$ 35,901,790$ & $\$ 32,629,473$ & $\$ 81,333,741$ & $\$ 82,927,747$ & $\$ 81,549,045$ \\
\hline Discount Factor & 0.5645 & 0.5132 & 0.4665 & 0.4241 & 0.3855 & 0.3505 & 0.3186 & 0.2897 \\
\hline Annual Present Value & $\$ 20,827,587$ & $\$ 18,300,839$ & $\$ 17,451,346$ & $\$ 15,225,863$ & $\$ 12,580,074$ & $\$ 28,506,980$ & $\$ 26,423,336$ & $\$ 23,621,853$ \\
\hline
\end{tabular}

Total Capital Investment + Interest

Net Present Worth 


\begin{tabular}{|c|c|c|c|c|c|c|c|c|}
\hline Year & 14 & 15 & 16 & 17 & 18 & 19 & 20 & 21 \\
\hline \multicolumn{9}{|l|}{$\begin{array}{l}\text { Fixed Capital Investment } \\
\text { Land } \\
\text { Working Capital }\end{array}$} \\
\hline Loan Payment & $\$ 0$ & $\$ 0$ & $\$ 0$ & $\$ 0$ & $\$ 0$ & $\$ 0$ & $\$ 0$ & $\$ 0$ \\
\hline Loan Interest Payment & $\$ 0$ & $\$ 0$ & $\$ 0$ & $\$ 0$ & $\$ 0$ & $\$ 0$ & $\$ 0$ & $\$ 0$ \\
\hline Loan Principal & $\$ 0$ & $\$ 0$ & $\$ 0$ & $\$ 0$ & $\$ 0$ & $\$ 0$ & $\$ 0$ & $\$ 0$ \\
\hline Fuel Sales & $\$ 199,428,121$ & $\$ 199,428,121$ & $\$ 199,428,121$ & $\$ 199,428,121$ & $\$ 199,428,121$ & $\$ 199,428,121$ & $\$ 199,428,121$ & $\$ 199,428,121$ \\
\hline By-Product Credit & $\$ 192,559,795$ & $\$ 192,559,795$ & $\$ 192,559,795$ & $\$ 192,559,795$ & $\$ 192,559,795$ & $\$ 192,559,795$ & $\$ 192,559,795$ & $\$ 192,559,795$ \\
\hline Total Annual Sales & $\$ 391,987,916$ & $\$ 391,987,916$ & $\$ 391,987,916$ & $\$ 391,987,916$ & $\$ 391,987,916$ & $\$ 391,987,916$ & $\$ 391,987,916$ & $\$ 391,987,916$ \\
\hline \multicolumn{9}{|l|}{ Annual Manufacturing Cost } \\
\hline Feedstock & $\$ 51,616,647$ & $\$ 51,616,647$ & $\$ 51,616,647$ & $\$ 51,616,647$ & $\$ 51,616,647$ & $\$ 51,616,647$ & $\$ 51,616,647$ & $\$ 51,616,647$ \\
\hline Periodic Costs (Catalyst, etc) & $\$ 0$ & $\$ 1,506,720$ & $\$ 749,801$ & $\$ 1,506,720$ & $\$ 0$ & $\$ 1,745,352$ & $\$ 0$ & $\$ 2,017,888$ \\
\hline Other Variable Costs & $\$ 215,685,824$ & $\$ 215,685,824$ & $\$ 215,685,824$ & $\$ 215,685,824$ & $\$ 215,685,824$ & $\$ 215,685,824$ & $\$ 215,685,824$ & $\$ 215,685,824$ \\
\hline Fixed Operating Costs & $\$ 20,426,101$ & $\$ 20,426,101$ & $\$ 20,426,101$ & $\$ 20,426,101$ & $\$ 20,426,101$ & $\$ 20,426,101$ & $\$ 20,426,101$ & $\$ 20,426,101$ \\
\hline Total Product Cost & $\$ 287,728,572$ & $\$ 289,235,292$ & $\$ 288,478,373$ & $\$ 289,235,292$ & $\$ 287,728,572$ & $\$ 289,473,924$ & $\$ 287,728,572$ & $\$ 289,746,460$ \\
\hline \multicolumn{9}{|l|}{ Annual Depreciation } \\
\hline \multicolumn{9}{|l|}{$\begin{array}{l}\text { General Plant Writedown } \\
\text { Depreciation Charge } \\
\text { Remaining Value }\end{array}$} \\
\hline Steam Plant Writedown & $4.46 \%$ & $4.46 \%$ & $4.46 \%$ & $4.46 \%$ & $4.46 \%$ & $4.46 \%$ & $4.46 \%$ & $2.23 \%$ \\
\hline Depreciation Charge & $\$ 2,680,309$ & $\$ 2,680,910$ & $\$ 2,680,309$ & $\$ 2,680,910$ & $\$ 2,680,309$ & $\$ 2,680,910$ & $\$ 2,680,309$ & $\$ 1,340,455$ \\
\hline Remaining Value & $\$ 17,424,114$ & $\$ 14,743,204$ & $\$ 12,062,894$ & $\$ 9,381,984$ & $\$ 6,701,675$ & $\$ 4,020,764$ & $\$ 1,340,455$ & $\$ 0$ \\
\hline Net Revenue & $\$ 101,579,035$ & $\$ 100,071,714$ & $\$ 100,829,234$ & $\$ 100,071,714$ & $\$ 101,579,035$ & $\$ 99,833,082$ & $\$ 101,579,035$ & $\$ 100,901,000$ \\
\hline Losses Forward & $\$ 0$ & $\$ 0$ & $\$ 0$ & $\$ 0$ & $\$ 0$ & $\$ 0$ & $\$ 0$ & $\$ 0$ \\
\hline Taxable Income & $\$ 101,579,035$ & $\$ 100,071,714$ & $\$ 100,829,234$ & $\$ 100,071,714$ & $\$ 101,579,035$ & $\$ 99,833,082$ & $\$ 101,579,035$ & $\$ 100,901,000$ \\
\hline Income Tax & $\$ 21,331,597$ & $\$ 21,015,060$ & $\$ 21,174,139$ & $\$ 21,015,060$ & $\$ 21,331,597$ & $\$ 20,964,947$ & $\$ 21,331,597$ & $\$ 21,189,210$ \\
\hline Annual Cash Income & $\$ 82,927,747$ & $\$ 81,737,564$ & $\$ 82,335,404$ & $\$ 81,737,564$ & $\$ 82,927,747$ & $\$ 81,549,045$ & $\$ 82,927,747$ & $\$ 81,052,245$ \\
\hline Discount Factor & 0.2633 & 0.2394 & 0.2176 & 0.1978 & 0.1799 & 0.1635 & 0.1486 & 0.1351 \\
\hline Annual Present Value & $\$ 21,837,468$ & $\$ 19,567,323$ & $\$ 17,918,583$ & $\$ 16,171,341$ & $\$ 14,915,284$ & $\$ 13,333,920$ & $\$ 12,326,681$ & $\$ 10,952,636$ \\
\hline
\end{tabular}

Total Capital Investment + Interest

Net Present Worth

\begin{tabular}{|c|c|c|c|c|c|c|c|c|c|}
\hline Year & 22 & 23 & 24 & 25 & 26 & 27 & 28 & 29 & 30 \\
\hline $\begin{array}{l}\text { Fixed Capital Investment } \\
\text { Land } \\
\text { Working Capital }\end{array}$ & & & & & & & & & $\begin{array}{r}(\$ 1,848,000) \\
(\$ 37,381,212)\end{array}$ \\
\hline Loan Payment & $\$ 0$ & $\$ 0$ & $\$ 0$ & $\$ 0$ & $\$ 0$ & $\$ 0$ & $\$ 0$ & $\$ 0$ & $\$ 0$ \\
\hline Loan Interest Payment & $\$ 0$ & $\$ 0$ & $\$ 0$ & $\$ 0$ & $\$ 0$ & $\$ 0$ & $\$ 0$ & $\$ 0$ & $\$ 0$ \\
\hline Loan Principal & $\$ 0$ & $\$ 0$ & $\$ 0$ & $\$ 0$ & $\$ 0$ & $\$ 0$ & $\$ 0$ & $\$ 0$ & $\$ 0$ \\
\hline Fuel Sales & $\$ 199,428,121$ & $\$ 199,428,121$ & $\$ 199,428,121$ & $\$ 199,428,121$ & $\$ 199,428,121$ & $\$ 199,428,121$ & $\$ 199,428,121$ & $\$ 199,428,121$ & $\$ 199,428,121$ \\
\hline By-Product Credit & $\$ 192,559,795$ & $\$ 192,559,795$ & $\$ 192,559,795$ & $\$ 192,559,795$ & $\$ 192,559,795$ & $\$ 192,559,795$ & $\$ 192,559,795$ & $\$ 192,559,795$ & $\$ 192,559,795$ \\
\hline Total Annual Sales & $\$ 391,987,916$ & $\$ 391,987,916$ & $\$ 391,987,916$ & $\$ 391,987,916$ & $\$ 391,987,916$ & $\$ 391,987,916$ & $\$ 391,987,916$ & $\$ 391,987,916$ & $\$ 391,987,916$ \\
\hline Annual Manufacturing Cost & & & & & & & & & \\
\hline Feedstock & $\$ 51,616,647$ & $\$ 51,616,647$ & $\$ 51,616,647$ & $\$ 51,616,647$ & $\$ 51,616,647$ & $\$ 51,616,647$ & $\$ 51,616,647$ & $\$ 51,616,647$ & $\$ 51,616,647$ \\
\hline Periodic Costs (Catalyst, etc) & $\$ 238,632$ & $\$ 1,506,720$ & $\$ 0$ & $\$ 1,745,352$ & $\$ 511,169$ & $\$ 1,506,720$ & $\$ 238,632$ & $\$ 1,506,720$ & $\$ 0$ \\
\hline Other Variable Costs & $\$ 215,685,824$ & $\$ 215,685,824$ & $\$ 215,685,824$ & $\$ 215,685,824$ & $\$ 215,685,824$ & $\$ 215,685,824$ & $\$ 215,685,824$ & $\$ 215,685,824$ & $\$ 215,685,824$ \\
\hline Fixed Operating Costs & $\$ 20,426,101$ & $\$ 20,426,101$ & $\$ 20,426,101$ & $\$ 20,426,101$ & $\$ 20,426,101$ & $\$ 20,426,101$ & $\$ 20,426,101$ & $\$ 20,426,101$ & $\$ 20,426,101$ \\
\hline Total Product Cost & $\$ 287,967,204$ & $\$ 289,235,292$ & $\$ 287,728,572$ & $\$ 289,473,924$ & $\$ 288,239,741$ & $\$ 289,235,292$ & $\$ 287,967,204$ & $\$ 289,235,292$ & $\$ 287,728,572$ \\
\hline $\begin{array}{l}\text { Annual Depreciation } \\
\text { General Plant Writedown } \\
\text { Depreciation Charge } \\
\text { Remaining Value } \\
\text { Steam Plant Writedown } \\
\text { Depreciation Charge } \\
\text { Remaining Value }\end{array}$ & & & & & & & & & \\
\hline Net Revenue & $\$ 104,020,712$ & $\$ 102,752,624$ & $\$ 104,259,344$ & $\$ 102,513,992$ & $\$ 103,748,175$ & $\$ 102,752,624$ & $\$ 104,020,712$ & $\$ 102,752,624$ & $\$ 104,259,344$ \\
\hline Losses Forward & $\$ 0$ & $\$ 0$ & $\$ 0$ & $\$ 0$ & $\$ 0$ & $\$ 0$ & $\$ 0$ & $\$ 0$ & $\$ 0$ \\
\hline Taxable Income & $\$ 104,020,712$ & $\$ 102,752,624$ & $\$ 104,259,344$ & $\$ 102,513,992$ & $\$ 103,748,175$ & $\$ 102,752,624$ & $\$ 104,020,712$ & $\$ 102,752,624$ & $\$ 104,259,344$ \\
\hline Income Tax & $\$ 21,844,350$ & $\$ 21,578,051$ & $\$ 21,894,462$ & $\$ 21,527,938$ & $\$ 21,787,117$ & $\$ 21,578,051$ & $\$ 21,844,350$ & $\$ 21,578,051$ & $\$ 21,894,462$ \\
\hline Annual Cash Income & $\$ 82,176,362$ & $\$ 81,174,573$ & $\$ 82,364,882$ & $\$ 80,986,054$ & $\$ 81,961,059$ & $\$ 81,174,573$ & $\$ 82,176,362$ & $\$ 81,174,573$ & $\$ 82,364,882$ \\
\hline Discount Factor & 0.1228 & 0.1117 & 0.1015 & 0.0923 & 0.0839 & 0.0763 & 0.0693 & 0.0630 & 0.0573 \\
\hline $\begin{array}{l}\text { Annual Present Value } \\
\text { Total Capital Investment + Interes }\end{array}$ & $\$ 10,095,035$ & $\$ 9,065,427$ & $\$ 8,362,144$ & $\$ 7,474,689$ & $\$ 6,876,980$ & $\$ 6,191,808$ & $\$ 5,698,384$ & $\$ 5,117,197$ & $\begin{array}{r}\$ 4,720,212 \\
(\$ 2,248,169)\end{array}$ \\
\hline
\end{tabular}




\section{Integrated Biorefinery}

\begin{tabular}{|c|c|c|c|c|c|c|c|c|c|}
\hline Year & & -2 & -1 & $\mathbf{0}$ & 1 & 2 & 3 & 4 & 5 \\
\hline Fixed Capital Investment & & $\$ 23,902,581$ & $\$ 179,269,356$ & $\$ 95,610,323$ & & & & & \\
\hline Land & & $\$ 1,848,000$ & & & & & & & \\
\hline Working Capital & & & & $\$ 37,347,783$ & & & & & \\
\hline Loan Payment & & & & & $\$ 66,791,051$ & $\$ 66,791,051$ & $\$ 66,791,051$ & $\$ 66,791,051$ & $\$ 66,791,051$ \\
\hline Loan Interest Payment & & $\$ 2,868,310$ & $\$ 24,380,632$ & $\$ 35,853,871$ & $\$ 35,853,871$ & $\$ 33,378,897$ & $\$ 30,705,924$ & $\$ 27,819,114$ & $\$ 24,701,359$ \\
\hline Loan Principal & & $\$ 35,853,871$ & $\$ 304,757,905$ & $\$ 448,173,390$ & $\$ 417,236,210$ & $\$ 383,824,056$ & $\$ 347,738,929$ & $\$ 308,766,992$ & $\$ 266,677,300$ \\
\hline Fuel Sales & & & & & $\$ 90,240,368$ & $\$ 120,320,491$ & $\$ 120,320,491$ & $\$ 120,320,491$ & $\$ 120,320,491$ \\
\hline By-Product Credit & & & & & $\$ 141,036,844$ & $\$ 188,049,126$ & $\$ 188,049,126$ & $\$ 188,049,126$ & $\$ 188,049,126$ \\
\hline Total Annual Sales & & & & & $\$ 231,277,213$ & $\$ 308,369,617$ & $\$ 308,369,617$ & $\$ 308,369,617$ & $\$ 308,369,617$ \\
\hline \multicolumn{10}{|l|}{ Annual Manufacturing Cost } \\
\hline Feedstock & & & & & $\$ 38,712,485$ & $\$ 51,616,647$ & $\$ 51,616,647$ & $\$ 51,616,647$ & $\$ 51,616,647$ \\
\hline Periodic Costs (Catalyst, etc) & & & & & $\$ 16,422,580$ & $\$ 0$ & $\$ 1,280,169$ & $\$ 2,249,147$ & $\$ 1,280,169$ \\
\hline Other Variable Costs & & & & & $\$ 116,478,855$ & $\$ 133,118,692$ & $\$ 133,118,692$ & $\$ 133,118,692$ & $\$ 133,118,692$ \\
\hline Fixed Operating Costs & & & & & $\$ 20,084,934$ & $\$ 20,084,934$ & $\$ 20,084,934$ & $\$ 20,084,934$ & $\$ 20,084,934$ \\
\hline Total Product Cost & & & & & $\$ 191,698,855$ & $\$ 204,820,273$ & $\$ 206,100,441$ & $\$ 207,069,420$ & $\$ 206,100,441$ \\
\hline \multicolumn{10}{|l|}{ Annual Depreciation } \\
\hline General Plant Writedown & & & & & $14 \%$ & $24.49 \%$ & $17.49 \%$ & $12.49 \%$ & $8.93 \%$ \\
\hline Depreciation Charge & & & & & $\$ 96,685,057$ & $\$ 165,697,484$ & $\$ 118,336,015$ & $\$ 84,506,394$ & $\$ 60,419,703$ \\
\hline Remaining Value & & & & & $\$ 579,907,365$ & $\$ 414,209,881$ & $\$ 295,873,866$ & $\$ 211,367,473$ & $\$ 150,947,769$ \\
\hline Steam Plant Writedown & & & & & $3.75 \%$ & $7.22 \%$ & $6.68 \%$ & $6.18 \%$ & $5.71 \%$ \\
\hline Depreciation Charge & & & & & $\$ 2,638,621$ & $\$ 5,079,521$ & $\$ 4,698,153$ & $\$ 4,346,337$ & $\$ 4,019,851$ \\
\hline Remaining Value & & & & & $\$ 67,724,607$ & $\$ 62,645,086$ & $\$ 57,946,933$ & $\$ 53,600,596$ & $\$ 49,580,745$ \\
\hline Net Revenue & & & & & $(\$ 95,599,192)$ & $(\$ 100,606,558)$ & $(\$ 51,470,916)$ & $(\$ 15,371,648)$ & $\$ 13,128,262$ \\
\hline Losses Forward & & & & & & $(\$ 95,599,192)$ & $(\$ 196,205,750)$ & $(\$ 247,676,666)$ & $(\$ 263,048,314)$ \\
\hline Taxable Income & & & & & $(\$ 95,599,192)$ & $(\$ 196,205,750)$ & $(\$ 247,676,666)$ & $(\$ 263,048,314)$ & $(\$ 249,920,052)$ \\
\hline Income Tax & & & & & $\$ 0$ & $\$ 0$ & $\$ 0$ & $\$ 0$ & $\$ 0$ \\
\hline Annual Cash Income & & & & & $-\$ 27,212,693$ & $\$ 36,758,293$ & $\$ 35,478,124$ & $\$ 34,509,146$ & $\$ 35,478,124$ \\
\hline Discount Factor & & 1.2100 & 1.1000 & 1.0000 & 0.9091 & 0.8264 & 0.7513 & 0.6830 & 0.6209 \\
\hline Annual Present Value & $\$ 425,209,568$ & & & & $-\$ 24,738,812$ & $\$ 30,378,755$ & $\$ 26,655,240$ & $\$ 23,570,211$ & $\$ 22,029,124$ \\
\hline
\end{tabular}

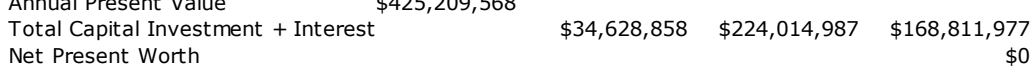

$\$ 0$

\begin{tabular}{|c|c|c|c|c|c|c|c|c|}
\hline Year & 6 & 7 & 8 & 9 & 10 & 11 & 12 & 13 \\
\hline \multicolumn{9}{|l|}{$\begin{array}{l}\text { Fixed Capital Investment } \\
\text { Land } \\
\text { Working Capital }\end{array}$} \\
\hline Loan Payment & $\$ 66,791,051$ & $\$ 66,791,051$ & $\$ 66,791,051$ & $\$ 66,791,051$ & $\$ 66,791,051$ & $\$ 0$ & $\$ 0$ & $\$ 0$ \\
\hline Loan Interest Payment & $\$ 21,334,184$ & $\$ 17,697,635$ & $\$ 13,770,161$ & $\$ 9,528,490$ & $\$ 4,947,485$ & $\$ 0$ & $\$ 0$ & $\$ 0$ \\
\hline Loan Principal & $\$ 221,220,433$ & $\$ 172,127,017$ & $\$ 119,106,127$ & $\$ 61,843,566$ & $\$ 0$ & $\$ 0$ & $\$ 0$ & $\$ 0$ \\
\hline Fuel Sales & $\$ 120,320,491$ & $\$ 120,320,491$ & $\$ 120,320,491$ & $\$ 120,320,491$ & $\$ 120,320,491$ & $\$ 120,320,491$ & $\$ 120,320,491$ & $\$ 120,320,491$ \\
\hline By-Product Credit & $\$ 188,049,126$ & $\$ 188,049,126$ & $\$ 188,049,126$ & $\$ 188,049,126$ & $\$ 188,049,126$ & $\$ 188,049,126$ & $\$ 188,049,126$ & $\$ 188,049,126$ \\
\hline Total Annual Sales & $\$ 308,369,617$ & $\$ 308,369,617$ & $\$ 308,369,617$ & $\$ 308,369,617$ & $\$ 308,369,617$ & $\$ 308,369,617$ & $\$ 308,369,617$ & $\$ 308,369,617$ \\
\hline \multicolumn{9}{|l|}{ Annual Manufacturing Cost } \\
\hline Feedstock & $\$ 51,616,647$ & $\$ 51,616,647$ & $\$ 51,616,647$ & $\$ 51,616,647$ & $\$ 51,616,647$ & $\$ 51,616,647$ & $\$ 51,616,647$ & $\$ 51,616,647$ \\
\hline Periodic Costs (Catalyst, etc) & $\$ 511,169$ & $\$ 3,529,316$ & $\$ 0$ & $\$ 1,280,169$ & $\$ 2,249,147$ & $\$ 1,791,337$ & $\$ 0$ & $\$ 3,529,316$ \\
\hline Other Variable Costs & $\$ 133,118,692$ & $\$ 133,118,692$ & $\$ 133,118,692$ & $\$ 133,118,692$ & $\$ 133,118,692$ & $\$ 133,118,692$ & $\$ 133,118,692$ & $\$ 133,118,692$ \\
\hline Fixed Operating Costs & $\$ 20,084,934$ & $\$ 20,084,934$ & $\$ 20,084,934$ & $\$ 20,084,934$ & $\$ 20,084,934$ & $\$ 20,084,934$ & $\$ 20,084,934$ & $\$ 20,084,934$ \\
\hline Total Product Cost & $\$ 205,331,441$ & $\$ 208,349,589$ & $\$ 204,820,273$ & $\$ 206,100,441$ & $\$ 207,069,420$ & $\$ 206,611,610$ & $\$ 204,820,273$ & $\$ 208,349,589$ \\
\hline \multicolumn{9}{|l|}{ Annual Depreciation } \\
\hline General Plant Writedown & $8.92 \%$ & $8.93 \%$ & $4.46 \%$ & & & & & \\
\hline Depreciation Charge & $\$ 60,352,044$ & $\$ 60,419,703$ & $\$ 30,176,022$ & & & & & \\
\hline Remaining Value & $\$ 90,595,725$ & $\$ 30,176,022$ & $\$ 0$ & & & & & \\
\hline Steam Plant Writedown & $5.29 \%$ & $4.89 \%$ & $4.52 \%$ & $4.46 \%$ & $4.46 \%$ & $4.46 \%$ & $4.46 \%$ & $4.46 \%$ \\
\hline Depreciation Charge & $\$ 3,718,697$ & $\$ 3,439,355$ & $\$ 3,181,825$ & $\$ 3,139,607$ & $\$ 3,138,904$ & $\$ 3,139,607$ & $\$ 3,138,904$ & $\$ 3,139,607$ \\
\hline Remaining Value & $\$ 45,862,048$ & $\$ 42,422,694$ & $\$ 39,240,869$ & $\$ 36,101,261$ & $\$ 32,962,358$ & $\$ 29,822,751$ & $\$ 26,683,847$ & $\$ 23,544,240$ \\
\hline Net Revenue & $\$ 17,633,251$ & $\$ 18,463,336$ & $\$ 56,421,336$ & $\$ 89,601,078$ & $\$ 93,213,808$ & $\$ 98,618,400$ & $\$ 100,410,441$ & $\$ 96,880,421$ \\
\hline Losses Forward & $(\$ 249,920,052)$ & $(\$ 232,286,801)$ & $(\$ 213,823,466)$ & $(\$ 157,402,130)$ & $-\$ 67,801,052$ & $\$ 0$ & $\$ 0$ & $\$ 0$ \\
\hline Taxable Income & $(\$ 232,286,801)$ & $(\$ 213,823,466)$ & $(\$ 157,402,130)$ & $-\$ 67,801,052$ & $\$ 25,412,756$ & $\$ 98,618,400$ & $\$ 100,410,441$ & $\$ 96,880,421$ \\
\hline Income Tax & $\$ 0$ & $\$ 0$ & $\$ 0$ & $\$ 0$ & $\$ 5,336,679$ & $\$ 20,709,864$ & $\$ 21,086,193$ & $\$ 20,344,888$ \\
\hline Annual Cash Income & $\$ 36,247,124$ & $\$ 33,228,977$ & $\$ 36,758,293$ & $\$ 35,478,124$ & $\$ 29,172,467$ & $\$ 81,048,143$ & $\$ 82,463,152$ & $\$ 79,675,140$ \\
\hline Discount Factor & 0.5645 & 0.5132 & 0.4665 & 0.4241 & 0.3855 & 0.3505 & 0.3186 & 0.2897 \\
\hline Annual Present Value & $\$ 20,460,557$ & $\$ 17,051,719$ & $\$ 17,148,015$ & $\$ 15,046,188$ & $\$ 11,247,249$ & $\$ 28,406,880$ & $\$ 26,275,301$ & $\$ 23,079,050$ \\
\hline
\end{tabular}

Total Capital Investment + Interest

Net Present Worth 


\begin{tabular}{|c|c|c|c|c|c|c|c|c|}
\hline Year & 14 & 15 & 16 & 17 & 18 & 19 & 20 & 21 \\
\hline \multicolumn{9}{|l|}{$\begin{array}{l}\text { Fixed Capital Investment } \\
\text { Land } \\
\text { Working Capital }\end{array}$} \\
\hline Loan Payment & $\$ 0$ & $\$ 0$ & $\$ 0$ & $\$ 0$ & $\$ 0$ & $\$ 0$ & $\$ 0$ & $\$ 0$ \\
\hline Loan Interest Payment & $\$ 0$ & $\$ 0$ & $\$ 0$ & $\$ 0$ & $\$ 0$ & $\$ 0$ & $\$ 0$ & $\$ 0$ \\
\hline Loan Principal & $\$ 0$ & $\$ 0$ & $\$ 0$ & $\$ 0$ & $\$ 0$ & $\$ 0$ & $\$ 0$ & $\$ 0$ \\
\hline Fuel Sales & $\$ 120,320,491$ & $\$ 120,320,491$ & $\$ 120,320,491$ & $\$ 120,320,491$ & $\$ 120,320,491$ & $\$ 120,320,491$ & $\$ 120,320,491$ & $\$ 120,320,491$ \\
\hline By-Product Credit & $\$ 188,049,126$ & $\$ 188,049,126$ & $\$ 188,049,126$ & $\$ 188,049,126$ & $\$ 188,049,126$ & $\$ 188,049,126$ & $\$ 188,049,126$ & $\$ 188,049,126$ \\
\hline Total Annual Sales & $\$ 308,369,617$ & $\$ 308,369,617$ & $\$ 308,369,617$ & $\$ 308,369,617$ & $\$ 308,369,617$ & $\$ 308,369,617$ & $\$ 308,369,617$ & $\$ 308,369,617$ \\
\hline \multicolumn{9}{|l|}{ Annual Manufacturing Cost } \\
\hline Feedstock & $\$ 51,616,647$ & $\$ 51,616,647$ & $\$ 51,616,647$ & $\$ 51,616,647$ & $\$ 51,616,647$ & $\$ 51,616,647$ & $\$ 51,616,647$ & $\$ 51,616,647$ \\
\hline Periodic Costs (Catalyst, etc) & $\$ 0$ & $\$ 1,280,169$ & $\$ 2,760,316$ & $\$ 1,280,169$ & $\$ 0$ & $\$ 3,529,316$ & $\$ 0$ & $\$ 1,791,337$ \\
\hline Other Variable Costs & $\$ 133,118,692$ & $\$ 133,118,692$ & $\$ 133,118,692$ & $\$ 133,118,692$ & $\$ 133,118,692$ & $\$ 133,118,692$ & $\$ 133,118,692$ & $\$ 133,118,692$ \\
\hline Fixed Operating Costs & $\$ 20,084,934$ & $\$ 20,084,934$ & $\$ 20,084,934$ & $\$ 20,084,934$ & $\$ 20,084,934$ & $\$ 20,084,934$ & $\$ 20,084,934$ & $\$ 20,084,934$ \\
\hline Total Product Cost & $\$ 204,820,273$ & $\$ 206,100,441$ & $\$ 207,580,589$ & $\$ 206,100,441$ & $\$ 204,820,273$ & $\$ 208,349,589$ & $\$ 204,820,273$ & $\$ 206,611,610$ \\
\hline \multicolumn{9}{|l|}{ Annual Depreciation } \\
\hline \multicolumn{9}{|l|}{$\begin{array}{l}\text { General Plant Writedown } \\
\text { Depreciation Charge } \\
\text { Remaining Value }\end{array}$} \\
\hline Steam Plant Writedown & $4.46 \%$ & $4.46 \%$ & $4.46 \%$ & $4.46 \%$ & $4.46 \%$ & $4.46 \%$ & $4.46 \%$ & $2.23 \%$ \\
\hline Depreciation Charge & $\$ 3,138,904$ & $\$ 3,139,607$ & $\$ 3,138,904$ & $\$ 3,139,607$ & $\$ 3,138,904$ & $\$ 3,139,607$ & $\$ 3,138,904$ & $\$ 1,569,804$ \\
\hline Remaining Value & $\$ 20,405,336$ & $\$ 17,265,729$ & $\$ 14,126,825$ & $\$ 10,987,218$ & $\$ 7,848,314$ & $\$ 4,708,707$ & $\$ 1,569,804$ & $\$ 0$ \\
\hline Net Revenue & $\$ 100,410,441$ & $\$ 99,129,568$ & $\$ 97,650,125$ & $\$ 99,129,568$ & $\$ 100,410,441$ & $\$ 96,880,421$ & $\$ 100,410,441$ & $\$ 100,188,203$ \\
\hline Losses Forward & $\$ 0$ & $\$ 0$ & $\$ 0$ & $\$ 0$ & $\$ 0$ & $\$ 0$ & $\$ 0$ & $\$ 0$ \\
\hline Taxable Income & $\$ 100,410,441$ & $\$ 99,129,568$ & $\$ 97,650,125$ & $\$ 99,129,568$ & $\$ 100,410,441$ & $\$ 96,880,421$ & $\$ 100,410,441$ & $\$ 100,188,203$ \\
\hline Income Tax & $\$ 21,086,193$ & $\$ 20,817,209$ & $\$ 20,506,526$ & $\$ 20,817,209$ & $\$ 21,086,193$ & $\$ 20,344,888$ & $\$ 21,086,193$ & $\$ 21,039,523$ \\
\hline Annual Cash Income & $\$ 82,463,152$ & $\$ 81,451,966$ & $\$ 80,282,502$ & $\$ 81,451,966$ & $\$ 82,463,152$ & $\$ 79,675,140$ & $\$ 82,463,152$ & $\$ 80,718,484$ \\
\hline Discount Factor & 0.2633 & 0.2394 & 0.2176 & 0.1978 & 0.1799 & 0.1635 & 0.1486 & 0.1351 \\
\hline Annual Present Value & $\$ 21,715,125$ & $\$ 19,498,953$ & $\$ 17,471,812$ & $\$ 16,114,837$ & $\$ 14,831,723$ & $\$ 13,027,522$ & $\$ 12,257,622$ & $\$ 10,907,535$ \\
\hline
\end{tabular}

Total Capital Investment + Interest

Net Present Worth

\begin{tabular}{|c|c|c|c|c|c|c|c|c|c|}
\hline Year & 22 & 23 & 24 & 25 & 26 & 27 & 28 & 29 & 30 \\
\hline \multicolumn{10}{|l|}{$\overline{\text { Fixed Capital Investment }}$} \\
\hline Land & & & & & & & & & $(\$ 1,848,000)$ \\
\hline Working Capital & & & & & & & & & $(\$ 37,347,783)$ \\
\hline Loan Payment & $\$ 0$ & $\$ 0$ & $\$ 0$ & $\$ 0$ & $\$ 0$ & $\$ 0$ & $\$ 0$ & $\$ 0$ & $\$ 0$ \\
\hline Loan Interest Payment & $\$ 0$ & $\$ 0$ & $\$ 0$ & $\$ 0$ & $\$ 0$ & $\$ 0$ & $\$ 0$ & $\$ 0$ & $\$ 0$ \\
\hline Loan Principal & $\$ 0$ & $\$ 0$ & $\$ 0$ & $\$ 0$ & $\$ 0$ & $\$ 0$ & $\$ 0$ & $\$ 0$ & $\$ 0$ \\
\hline Fuel Sales & $\$ 120,320,491$ & $\$ 120,320,491$ & $\$ 120,320,491$ & $\$ 120,320,491$ & $\$ 120,320,491$ & $\$ 120,320,491$ & $\$ 120,320,491$ & $\$ 120,320,491$ & $\$ 120,320,491$ \\
\hline By-Product Credit & $\$ 188,049,126$ & $\$ 188,049,126$ & $\$ 188,049,126$ & $\$ 188,049,126$ & $\$ 188,049,126$ & $\$ 188,049,126$ & $\$ 188,049,126$ & $\$ 188,049,126$ & $\$ 188,049,126$ \\
\hline Total Annual Sales & $\$ 308,369,617$ & $\$ 308,369,617$ & $\$ 308,369,617$ & $\$ 308,369,617$ & $\$ 308,369,617$ & $\$ 308,369,617$ & $\$ 308,369,617$ & $\$ 308,369,617$ & $\$ 308,369,617$ \\
\hline \multicolumn{10}{|l|}{ Annual Manufacturing Cost } \\
\hline Feedstock & $\$ 51,616,647$ & $\$ 51,616,647$ & $\$ 51,616,647$ & $\$ 51,616,647$ & $\$ 51,616,647$ & $\$ 51,616,647$ & $\$ 51,616,647$ & $\$ 51,616,647$ & $\$ 51,616,647$ \\
\hline Periodic Costs (Catalyst, etc) & $\$ 2,249,147$ & $\$ 1,280,169$ & $\$ 0$ & $\$ 3,529,316$ & $\$ 511,169$ & $\$ 1,280,169$ & $\$ 2,249,147$ & $\$ 1,280,169$ & $\$ 0$ \\
\hline Other Variable Costs & $\$ 133,118,692$ & $\$ 133,118,692$ & $\$ 133,118,692$ & $\$ 133,118,692$ & $\$ 133,118,692$ & $\$ 133,118,692$ & $\$ 133,118,692$ & $\$ 133,118,692$ & $\$ 133,118,692$ \\
\hline Fixed Operating Costs & $\$ 20,084,934$ & $\$ 20,084,934$ & $\$ 20,084,934$ & $\$ 20,084,934$ & $\$ 20,084,934$ & $\$ 20,084,934$ & $\$ 20,084,934$ & $\$ 20,084,934$ & $\$ 20,084,934$ \\
\hline Total Product Cost & $\$ 207,069,420$ & $\$ 206,100,441$ & $\$ 204,820,273$ & $\$ 208,349,589$ & $\$ 205,331,441$ & $\$ 206,100,441$ & $\$ 207,069,420$ & $\$ 206,100,441$ & $\$ 204,820,273$ \\
\hline \multicolumn{10}{|l|}{ Annual Depreciation } \\
\hline \multicolumn{10}{|l|}{$\begin{array}{l}\text { General Plant Writedown } \\
\text { Depreciation Charge } \\
\text { Remaining Value } \\
\text { Steam Plant Writedown } \\
\text { Depreciation Charge } \\
\text { Remaining Value } \\
\end{array}$} \\
\hline Net Revenue & $\$ 101,300,197$ & $\$ 102,269,175$ & $\$ 103,549,344$ & $\$ 100,020,028$ & $\$ 103,038,176$ & $\$ 102,269,175$ & $\$ 101,300,197$ & $\$ 102,269,175$ & $\$ 103,549,344$ \\
\hline Losses Forward & $\$ 0$ & $\$ 0$ & $\$ 0$ & $\$ 0$ & $\$ 0$ & $\$ 0$ & $\$ 0$ & $\$ 0$ & $\$ 0$ \\
\hline Taxable Income & $\$ 101,300,197$ & $\$ 102,269,175$ & $\$ 103,549,344$ & $\$ 100,020,028$ & $\$ 103,038,176$ & $\$ 102,269,175$ & $\$ 101,300,197$ & $\$ 102,269,175$ & $\$ 103,549,344$ \\
\hline Income Tax & $\$ 21,273,041$ & $\$ 21,476,527$ & $\$ 21,745,362$ & $\$ 21,004,206$ & $\$ 21,638,017$ & $\$ 21,476,527$ & $\$ 21,273,041$ & $\$ 21,476,527$ & $\$ 21,745,362$ \\
\hline Annual Cash Income & $\$ 80,027,156$ & $\$ 80,792,649$ & $\$ 81,803,982$ & $\$ 79,015,822$ & $\$ 81,400,159$ & $\$ 80,792,649$ & $\$ 80,027,156$ & $\$ 80,792,649$ & $\$ 81,803,982$ \\
\hline Discount Factor & 0.1228 & 0.1117 & 0.1015 & 0.0923 & 0.0839 & 0.0763 & 0.0693 & 0.0630 & 0.0573 \\
\hline $\begin{array}{l}\text { Annual Present Value } \\
\text { Total Capital Investment + Interest }\end{array}$ & $\$ 9,831,014$ & $\$ 9,022,774$ & $\$ 8,305,198$ & $\$ 7,292,844$ & $\$ 6,829,917$ & $\$ 6,162,676$ & $\$ 5,549,351$ & $\$ 5,093,121$ & $\begin{array}{r}\$ 4,688,068 \\
(\$ 2,246,254)\end{array}$ \\
\hline
\end{tabular}




\section{Appendix C. Key Aspen Stream Data Tables}

High-level stream table information from Aspen Plus modeling output follows, for key streams associated with each process operation area under both pathway scenarios. Space for stream tables was limited; below is a key to lumped components. As the stream table information focuses primarily on the high-level overall process and does not include every individual modeled stream within each process area, mass balance closure around a given unit area may not be $100 \%$.

Other sugars (SS)

Other organic acids (SS)

Fermentation nutrients (SS)

Other chemicals (SS)

Solvent

$\mathrm{CO} / \mathrm{SO}_{\mathrm{X}} / \mathrm{NO}_{\mathrm{X}} / \mathrm{H}_{2} \mathrm{~S}$

Other structural carbohydrates (IS)

Protein (IS)

Cell mass (IS)

Other insoluble solids (IS)
Arabinose, cellobiose, mannose, galactose, sucrose

Acetic, succinic, muconic, and lactic acids, extractives

Ammonia, CSL, diammonium phosphate, other minor nutrients

Aluminum chloride, other minor compounds

Dioxane, ethanol

$\mathrm{NO}, \mathrm{NO}_{2}, \mathrm{SO}_{2}, \mathrm{CO}, \mathrm{H}_{2} \mathrm{~S}$

Xylan, arabinan, galactan, mannan

Corn protein, enzymes, denatured enzymes

Cell biomass for fermentation, enzyme, and wastewater

organisms

Ash, lime 


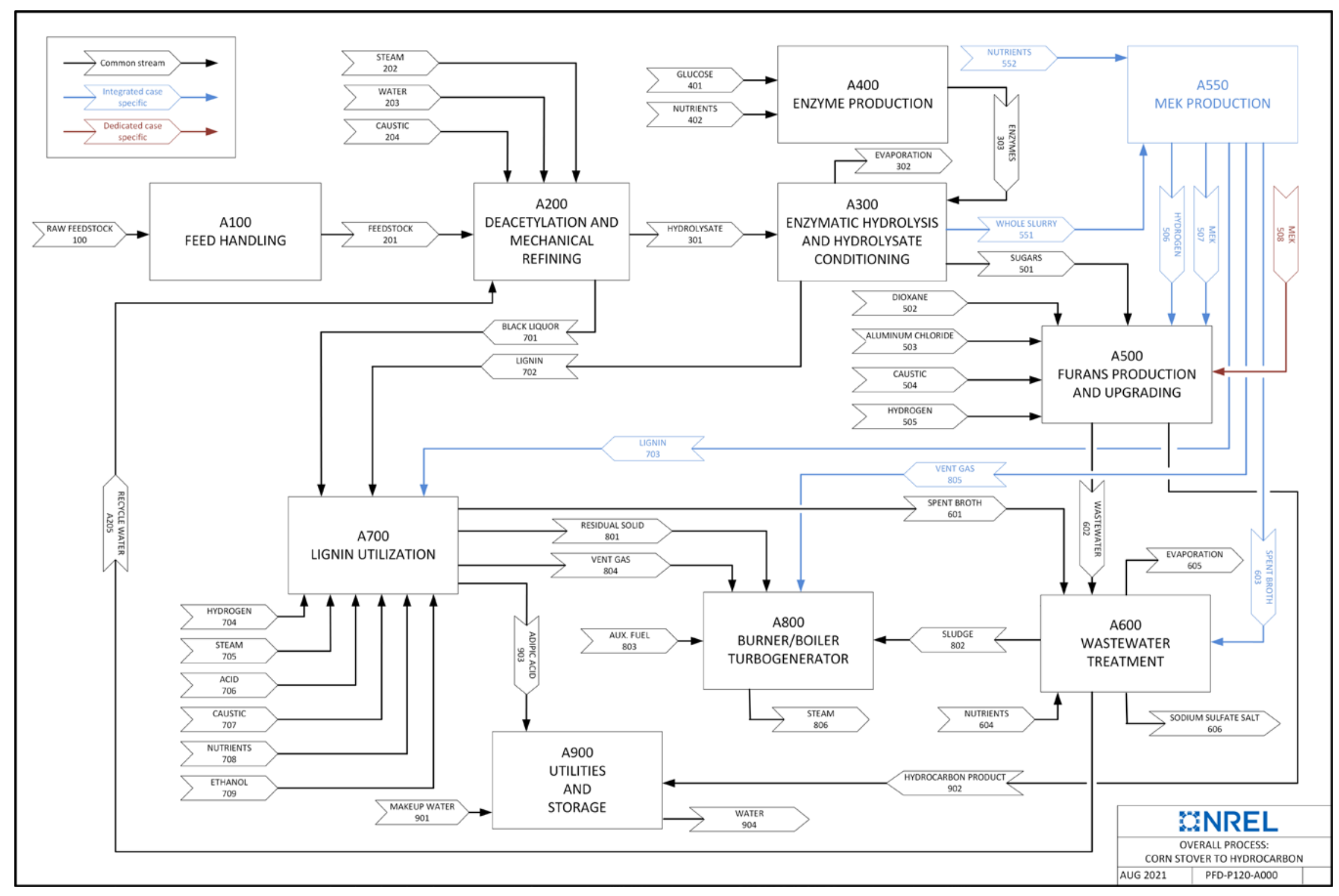


Dedicated Biorefinery

\begin{tabular}{|c|c|c|c|c|c|c|c|c|c|c|c|c|c|c|}
\hline DEDICATED BIOREFINERY & & 100 & 201 & 202 & 203 & 204 & 205 & 301 & 302 & 303 & 401 & 402 & 501 & 502 \\
\hline Total flow & $\mathrm{kg} / \mathrm{h}$ & 104,167 & 104,167 & 17,982 & 39,884 & 5,833 & 155,649 & 230,647 & 274,768 & 7,575 & 1,557 & 25,828 & 86,974 & 209 \\
\hline Insoluble solids (IS) & $\mathrm{kg} / \mathrm{h}$ & 70,483 & 70,483 & & & & & 57,306 & & 398 & & 86 & 86 & \\
\hline Soluble solids (SS) & $\mathrm{kg} / \mathrm{h}$ & 12,850 & 12,850 & & & 5,833 & & 321 & & 22 & 1,324 & 1,386 & 43,363 & \\
\hline Renewable hydrocarbon & $\mathrm{kg} / \mathrm{h}$ & & & & & & & & & & & & & \\
\hline Adipic acid & $\mathrm{kg} / \mathrm{h}$ & & & & & & & & & & & & & \\
\hline Water & $\mathrm{kg} / \mathrm{h}$ & 20,833 & 20,833 & 17,982 & 39,884 & & 155,649 & 173,020 & 274,768 & 7,147 & 234 & 7,682 & 43,517 & \\
\hline Glucose (SS) & $\mathrm{kg} / \mathrm{h}$ & & & & & & & & & & 1,324 & 1,264 & 27,190 & \\
\hline Xylose (SS) & $\mathrm{kg} / \mathrm{h}$ & & & & & & & & & & & & 14,230 & \\
\hline Other sugars (SS) & $\mathrm{kg} / \mathrm{h}$ & 642 & 642 & & & & & 321 & & & & & 1,923 & \\
\hline Other organic acids (SS) & $\mathrm{kg} / \mathrm{h}$ & 12,208 & 12,208 & & & & & & & 22 & & 25 & 21 & \\
\hline Fermentation nutrients (SS) & $\mathrm{kg} / \mathrm{h}$ & & & & & & & & & & & 97 & & \\
\hline Sulfuric acid (SS) & $\mathrm{kg} / \mathrm{h}$ & & & & & & & & & & & & & \\
\hline Sodium hydroxide (SS) & $\mathrm{kg} / \mathrm{h}$ & & & & & 5,833 & & & & & & & & \\
\hline Sodium sulfate (SS) & $\mathrm{kg} / \mathrm{h}$ & & & & & & & & & & & & & \\
\hline Other chemicals (SS) & $\mathrm{kg} / \mathrm{h}$ & & & & & & & & & & & & & \\
\hline Solvent & $\mathrm{kg} / \mathrm{h}$ & & & & & & & & & & & & & 209 \\
\hline Other organics & $\mathrm{kg} / \mathrm{h}$ & & & & & & & & & 7 & & 8 & 7 & \\
\hline Carbon dioxide & $\mathrm{kg} / \mathrm{h}$ & & & & & & & & & & & & & \\
\hline Methane & $\mathrm{kg} / \mathrm{h}$ & & & & & & & & & & & & & \\
\hline $\mathrm{H}_{2}$ & $\mathrm{~kg} / \mathrm{h}$ & & & & & & & & & & & & & \\
\hline $\mathrm{O}_{2}$ & $\mathrm{~kg} / \mathrm{h}$ & & & & & & & & & & & 3,880 & & \\
\hline $\mathrm{N}_{2}$ & $\mathrm{~kg} / \mathrm{h}$ & & & & & & & & & & & 12,777 & & \\
\hline $\mathrm{CO} / \mathrm{SO}_{x} / \mathrm{NO}_{x} / \mathrm{H}_{2} \mathrm{~S}$ & $\mathrm{~kg} / \mathrm{h}$ & & & & & & & & & & & 9 & & \\
\hline Cellulose (IS) & $\mathrm{kg} / \mathrm{h}$ & 29,205 & 29,205 & & & & & 28,621 & & & & & 13 & \\
\hline Other struct. carbohydr. (IS) & $\mathrm{kg} / \mathrm{h}$ & 19,948 & 19,948 & & & & & 17,725 & & & & & 17 & \\
\hline Acetate (IS) & $\mathrm{kg} / \mathrm{h}$ & 1,508 & 1,508 & & & & & & & & & & & \\
\hline Lignin (IS) & $\mathrm{kg} / \mathrm{h}$ & 13,132 & 13,132 & & & & & 6,960 & & & & & 35 & \\
\hline Protein (IS) & $\mathrm{kg} / \mathrm{h}$ & 2,583 & 2,583 & & & & & 2,583 & & 23 & & 25 & 13 & \\
\hline Cell mass (IS) & $\mathrm{kg} / \mathrm{h}$ & & & & & & & & & 59 & & 25 & & \\
\hline Other insoluble solids (IS) & $\mathrm{kg} / \mathrm{h}$ & 4,108 & 4,108 & & & & & 1,417 & & 317 & & 36 & 9 & \\
\hline
\end{tabular}




\begin{tabular}{|c|c|c|c|c|c|c|c|c|c|c|c|c|c|c|}
\hline \multicolumn{2}{|l|}{ DEDICATED BIOREFINERY } & 503 & 504 & 505 & 508 & 601 & 602 & 604 & 605 & 606 & 701 & 702 & 704 & 705 \\
\hline Total flow & $\mathrm{kg} / \mathrm{h}$ & 949 & 1,220 & 3,341 & 9,395 & 174,104 & 73,209 & & 248,158 & 13,770 & 92,868 & 47,698 & 426 & 2,965 \\
\hline Insoluble solids (IS) & $\mathrm{kg} / \mathrm{h}$ & & & & & & 86 & & & & 11,669 & 17,155 & & \\
\hline Soluble solids (SS) & $\mathrm{kg} / \mathrm{h}$ & 949 & 1,220 & & & 17,044 & 2,189 & & & 13,770 & 19,871 & 2,282 & & \\
\hline MEK & $\mathrm{kg} / \mathrm{h}$ & & & & 9,301 & & & & & & & & & \\
\hline Renewable hydrocarbon & $\mathrm{kg} / \mathrm{h}$ & & & & & & & & & & & & & \\
\hline Adipic acid & $\mathrm{kg} / \mathrm{h}$ & & & & & & & & & & & & & \\
\hline Water & $\mathrm{kg} / \mathrm{h}$ & & & & 94 & 156,882 & 70,716 & & 248,157 & & 61,329 & 28,260 & & 2,965 \\
\hline Glucose (SS) & $\mathrm{kg} / \mathrm{h}$ & & & & & 59 & & & & & & 1,431 & & \\
\hline Xylose (SS) & $\mathrm{kg} / \mathrm{h}$ & & & & & 59 & & & & & & 749 & & \\
\hline Other sugars (SS) & $\mathrm{kg} / \mathrm{h}$ & & & & & 899 & & & & & 321 & 101 & & \\
\hline Other organic acids (SS) & $\mathrm{kg} / \mathrm{h}$ & & & & & 452 & 21 & & & & 13,716 & 1 & & \\
\hline Fermentation nutrients (SS) & $\mathrm{kg} / \mathrm{h}$ & & & & & 5 & & & & & & & & \\
\hline Sulfuric acid (SS) & $\mathrm{kg} / \mathrm{h}$ & & & & & & & & & & & & & \\
\hline Sodium hydroxide (SS) & $\mathrm{kg} / \mathrm{h}$ & & 1,220 & & & & 1,220 & & & & 5,833 & & & \\
\hline Sodium sulfate (SS) & $\mathrm{kg} / \mathrm{h}$ & & & & & 15,570 & & & & 13,770 & & & & \\
\hline Other chemicals (SS) & $\mathrm{kg} / \mathrm{h}$ & 949 & & & & & 949 & & & & & & & \\
\hline Soluble lignin & $\mathrm{kg} / \mathrm{h}$ & & & & & 134 & & & & & & & & \\
\hline Solvent & $\mathrm{kg} / \mathrm{h}$ & & & & & & 210 & & & & & & & \\
\hline Other organics & $\mathrm{kg} / \mathrm{h}$ & & & & & & 7 & & & & & & & \\
\hline Carbon dioxide & $\mathrm{kg} / \mathrm{h}$ & & & & & 37 & & & & & & & & \\
\hline Methane & $\mathrm{kg} / \mathrm{h}$ & & & & & & & & & & & & & \\
\hline $\mathrm{H}_{2}$ & $\mathrm{~kg} / \mathrm{h}$ & & & 3,341 & & 5 & & & & & & & 426 & \\
\hline $\mathrm{O}_{2}$ & $\mathrm{~kg} / \mathrm{h}$ & & & & & & & & & & & & & \\
\hline $\mathrm{N}_{2}$ & $\mathrm{~kg} / \mathrm{h}$ & & & & & 2 & & & & & & & & \\
\hline $\mathrm{CO} / \mathrm{SO}_{x} / \mathrm{NO}_{x} / \mathrm{H}_{2} \mathrm{~S}$ & $\mathrm{~kg} / \mathrm{h}$ & & & & & & & & & & & & & \\
\hline Cellulose (IS) & $\mathrm{kg} / \mathrm{h}$ & & & & & & 13 & & & & 584 & 2,506 & & \\
\hline Other struct. carbohydr. (IS) & $\mathrm{kg} / \mathrm{h}$ & & & & & & 17 & & & & 2,222 & 3,347 & & \\
\hline Acetate (IS) & $\mathrm{kg} / \mathrm{h}$ & & & & & & & & & & & & & \\
\hline Lignin (IS) & $\mathrm{kg} / \mathrm{h}$ & & & & & & 35 & & & & 6,172 & 6,925 & & \\
\hline Protein (IS) & $\mathrm{kg} / \mathrm{h}$ & & & & & & 13 & & & & & 2,593 & & \\
\hline Cell mass (IS) & $\mathrm{kg} / \mathrm{h}$ & & & & & & & & & & & 59 & & \\
\hline Other insoluble solids (IS) & $\mathrm{kg} / \mathrm{h}$ & & & & & & 9 & & & & 2,691 & 1,725 & & \\
\hline
\end{tabular}




\begin{tabular}{|c|c|c|c|c|c|c|c|c|c|c|c|c|c|c|}
\hline DEDICATED BIOREFINERY & & 706 & 707 & 708 & 709 & 801 & 802 & 803 & 804 & 806 & 901 & 902 & 903 & 904 \\
\hline Total flow & $\mathrm{kg} / \mathrm{h}$ & 11,560 & 3,218 & 855 & 39 & 14,896 & 2,236 & 6,500 & 51,290 & 230,378 & 248,158 & 28,139 & 11,843 & 522,926 \\
\hline Insoluble solids (IS) & $\mathrm{kg} / \mathrm{h}$ & & & 36 & & 7,448 & 447 & & & & & & & \\
\hline Soluble solids (SS) & $\mathrm{kg} / \mathrm{h}$ & 10,751 & 3,218 & 746 & & 843 & 129 & & 12 & & & & & \\
\hline MEK & $\mathrm{kg} / \mathrm{h}$ & & & & & & & & & & & & & \\
\hline Renewable hydrocarbon & $\mathrm{kg} / \mathrm{h}$ & & & & & & & & & & & 27,746 & & \\
\hline Adipic acid & $\mathrm{kg} / \mathrm{h}$ & & & & & & & & & & & & 11,812 & \\
\hline Water & $\mathrm{kg} / \mathrm{h}$ & 809 & & 72 & & 6,598 & 1,658 & & 1,221 & 230,378 & 248,158 & 393 & & 522,926 \\
\hline Glucose (SS) & $\mathrm{kg} / \mathrm{h}$ & & & & & 3 & & & & & & & & \\
\hline Xylose (SS) & $\mathrm{kg} / \mathrm{h}$ & & & & & 3 & & & & & & & & \\
\hline Other sugars (SS) & $\mathrm{kg} / \mathrm{h}$ & & & & & 39 & & & & & & & & \\
\hline Other organic acids (SS) & $\mathrm{kg} / \mathrm{h}$ & & & 36 & & 516 & & & 12 & & & & & \\
\hline Fermentation nutrients (SS) & $\mathrm{kg} / \mathrm{h}$ & & & 711 & & & & & & & & & & \\
\hline Sulfuric acid (SS) & $\mathrm{kg} / \mathrm{h}$ & 10,751 & & & & & & & & & & & & \\
\hline Sodium hydroxide (SS) & $\mathrm{kg} / \mathrm{h}$ & & 3,218 & & & 283 & 9 & & & & & & & \\
\hline Sodium sulfate (SS) & $\mathrm{kg} / \mathrm{h}$ & & & & & & 113 & & & & & & & \\
\hline Other chemicals (SS) & $\mathrm{kg} / \mathrm{h}$ & & & & & & 7 & & & & & & & \\
\hline Soluble lignin & $\mathrm{kg} / \mathrm{h}$ & & & & & 6 & & & & & & & & \\
\hline Solvent & $\mathrm{kg} / \mathrm{h}$ & & & & 39 & & 1 & & 8 & & & & 31 & \\
\hline Other organics & $\mathrm{kg} / \mathrm{h}$ & & & & & & & & & & & & & \\
\hline Carbon dioxide & $\mathrm{kg} / \mathrm{h}$ & & & & & 2 & & & 11,345 & & & & & \\
\hline Methane & $\mathrm{kg} / \mathrm{h}$ & & & & & & & 6,500 & & & & & & \\
\hline $\mathrm{H}_{2}$ & $\mathrm{~kg} / \mathrm{h}$ & & & & & & & & 95 & & & & & \\
\hline $\mathrm{O}_{2}$ & $\mathrm{~kg} / \mathrm{h}$ & & & & & & & & 1,820 & & & & & \\
\hline $\mathrm{N}_{2}$ & $\mathrm{~kg} / \mathrm{h}$ & & & & & & & & 36,789 & & & & & \\
\hline $\mathrm{CO} / \mathrm{SO}_{x} / \mathrm{NO}_{x} / \mathrm{H}_{2} \mathrm{~S}$ & $\mathrm{~kg} / \mathrm{h}$ & & & & & & & & & & & & & \\
\hline Cellulose (IS) & $\mathrm{kg} / \mathrm{h}$ & & & & & & 13 & & & & & & & \\
\hline Other struct. carbohydr. (IS) & $\mathrm{kg} / \mathrm{h}$ & & & & & & 17 & & & & & & & \\
\hline Acetate (IS) & $\mathrm{kg} / \mathrm{h}$ & & & & & & & & & & & & & \\
\hline Lignin (IS) & $\mathrm{kg} / \mathrm{h}$ & & & & & & 35 & & & & & & & \\
\hline Protein (IS) & $\mathrm{kg} / \mathrm{h}$ & & & 36 & & 69 & & & & & & & & \\
\hline Cell mass (IS) & $\mathrm{kg} / \mathrm{h}$ & & & & & 7,378 & 374 & & & & & & & \\
\hline Other insoluble solids (IS) & $\mathrm{kg} / \mathrm{h}$ & & & & & & 9 & & & & & & & \\
\hline
\end{tabular}


Integrated Biorefinery

\begin{tabular}{|c|c|c|c|c|c|c|c|c|c|c|c|c|c|c|c|c|}
\hline INTEGRATED BIOREFINEF & & 100 & 201 & 202 & 203 & 204 & 205 & 301 & 302 & 303 & 401 & 402 & 501 & 502 & 503 & 504 \\
\hline Total flow & $\mathrm{kg} / \mathrm{h}$ & 104,167 & 104,167 & 17,982 & 39,884 & 5,833 & 155,649 & 230,647 & 155,009 & 7,575 & 1,557 & 25,828 & 49,053 & 120 & 535 & 688 \\
\hline Insoluble solids (IS) & $\mathrm{kg} / \mathrm{h}$ & 70,483 & 70,483 & & & & & 57,306 & & 398 & & 86 & 49 & & & \\
\hline Soluble solids (SS) & $\mathrm{kg} / \mathrm{h}$ & 12,850 & 12,850 & & & 5,833 & & 321 & & 22 & 1,324 & 1,386 & 24,462 & & 535 & 688 \\
\hline Renewable hydrocarbon & $\mathrm{kg} / \mathrm{h}$ & & & & & & & & & & & & & & & \\
\hline Adipic acid & $\mathrm{kg} / \mathrm{h}$ & & & & & & & & & & & & & & & \\
\hline Water & $\mathrm{kg} / \mathrm{h}$ & 20,833 & 20,833 & 17,982 & 39,884 & & 155,649 & 173,020 & 155,008 & 7,147 & 234 & 7,682 & 24,539 & & & \\
\hline Glucose (SS) & $\mathrm{kg} / \mathrm{h}$ & & & & & & & & & & 1,324 & 1,264 & 15,338 & & & \\
\hline Xylose (SS) & $\mathrm{kg} / \mathrm{h}$ & & & & & & & & & & & & 8,027 & & & \\
\hline Other sugars (SS) & $\mathrm{kg} / \mathrm{h}$ & 642 & 642 & & & & & 321 & & & & & 1,085 & & & \\
\hline Other organic acids (SS) & $\mathrm{kg} / \mathrm{h}$ & 12,208 & 12,208 & & & & & & & 22 & & 25 & 12 & & & \\
\hline Fermentation nutrients (SS) & $\mathrm{kg} / \mathrm{h}$ & & & & & & & & & & & 97 & & & & \\
\hline Sulfuric acid (SS) & $\mathrm{kg} / \mathrm{h}$ & & & & & & & & & & & & & & & \\
\hline Sodium hydroxide (SS) & $\mathrm{kg} / \mathrm{h}$ & & & & & 5,833 & & & & & & & & & & 688 \\
\hline Sodium sulfate (SS) & $\mathrm{kg} / \mathrm{h}$ & & & & & & & & & & & & & & & \\
\hline Other chemicals (SS) & $\mathrm{kg} / \mathrm{h}$ & & & & & & & & & & & & & & 535 & \\
\hline Solvent & $\mathrm{kg} / \mathrm{h}$ & & & & & & & & & & & & & 120 & & \\
\hline Other organics & $\mathrm{kg} / \mathrm{h}$ & & & & & & & & & 7 & & 8 & 4 & & & \\
\hline Carbon dioxide & $\mathrm{kg} / \mathrm{h}$ & & & & & & & & & & & & & & & \\
\hline Methane & $\mathrm{kg} / \mathrm{h}$ & & & & & & & & & & & & & & & \\
\hline $\mathrm{H}_{2}$ & $\mathrm{~kg} / \mathrm{h}$ & & & & & & & & & & & & & & & \\
\hline $\mathrm{O}_{2}$ & $\mathrm{~kg} / \mathrm{h}$ & & & & & & & & & & & 3,880 & & & & \\
\hline $\mathrm{N}_{2}$ & $\mathrm{~kg} / \mathrm{h}$ & & & & & & & & & & & 12,777 & & & & \\
\hline $\mathrm{CO} / \mathrm{SO}_{x} / \mathrm{NO}_{x} / \mathrm{H}_{2} \mathrm{~S}$ & $\mathrm{~kg} / \mathrm{h}$ & & & & & & & & & & & 9 & & & & \\
\hline Cellulose (IS) & $\mathrm{kg} / \mathrm{h}$ & 29,205 & 29,205 & & & & & 28,621 & & & & & 7 & & & \\
\hline Other struct. carbohydr. (IS) & $\mathrm{kg} / \mathrm{h}$ & 19,948 & 19,948 & & & & & 17,725 & & & & & 9 & & & \\
\hline Acetate (IS) & $\mathrm{kg} / \mathrm{h}$ & 1,508 & 1,508 & & & & & & & & & & & & & \\
\hline Lignin (IS) & $\mathrm{kg} / \mathrm{h}$ & 13,132 & 13,132 & & & & & 6,960 & & & & & 20 & & & \\
\hline Protein (IS) & $\mathrm{kg} / \mathrm{h}$ & 2,583 & 2,583 & & & & & 2,583 & & 23 & & 25 & 7 & & & \\
\hline Cell mass (IS) & $\mathrm{kg} / \mathrm{h}$ & & & & & & & & & 59 & & 25 & & & & \\
\hline Other insoluble solids (IS) & $\mathrm{kg} / \mathrm{h}$ & 4,108 & 4,108 & & & & & 1,417 & & 317 & & 36 & 5 & & & \\
\hline
\end{tabular}




\begin{tabular}{|c|c|c|c|c|c|c|c|c|c|c|c|c|c|c|c|c|}
\hline INTEGRATED BIOREFINER & & 505 & 506 & 507 & 551 & 552 & 601 & 602 & 603 & 604 & 605 & 606 & 701 & 702 & 703 & 704 \\
\hline Total flow & $\mathrm{kg} / \mathrm{h}$ & 1,798 & 188 & 6,180 & 103,838 & & 163,967 & 42,167 & 77,848 & 55 & 282,439 & 13,946 & 92,868 & 26,907 & 10,865 & 417 \\
\hline Insoluble solids (IS) & $\mathrm{kg} / \mathrm{h}$ & & & & 7,515 & & & 49 & 159 & & & & 11,669 & 9,677 & 7,769 & \\
\hline Soluble solids (SS) & $\mathrm{kg} / \mathrm{h}$ & & & & 19,896 & & 16,598 & 1,235 & 1,591 & 55 & & 13,946 & 19,871 & 1,287 & 59 & \\
\hline Renewable hydrocarbon & $\mathrm{kg} / \mathrm{h}$ & & & & & & & & & & & & & & & \\
\hline Adipic acid & $\mathrm{kg} / \mathrm{h}$ & & & & & & & & & & & & & & & \\
\hline Water & $\mathrm{kg} / \mathrm{h}$ & & & 933 & 76,423 & & 146,883 & 40,761 & 74,389 & & 282,438 & & 61,329 & 15,942 & 2,714 & \\
\hline Xylose (SS) & $\mathrm{kg} / \mathrm{h}$ & & & & 6,529 & & 53 & & 466 & & & & & 422 & 17 & \\
\hline Other sugars (SS) & $\mathrm{kg} / \mathrm{h}$ & & & & 882 & & 890 & & 221 & & & & 321 & 57 & 8 & \\
\hline Other organic acids (SS) & $\mathrm{kg} / \mathrm{h}$ & & & & 10 & & 461 & 12 & 647 & & & & 13,716 & & 24 & \\
\hline Fermentation nutrients (SS) & $\mathrm{kg} / \mathrm{h}$ & & & & & & 5 & & 25 & 55 & & & & & & \\
\hline Sulfuric acid (SS) & $\mathrm{kg} / \mathrm{h}$ & & & & & & & & & & & & & & & \\
\hline Sodium hydroxide (SS) & $\mathrm{kg} / \mathrm{h}$ & & & & & & & 688 & & & & & 5,833 & & & \\
\hline Sodium sulfate (SS) & $\mathrm{kg} / \mathrm{h}$ & & & & & & 15,140 & & & & & 13,946 & & & & \\
\hline Other chemicals (SS) & $\mathrm{kg} / \mathrm{h}$ & & & & & & & 535 & & & & & & & & \\
\hline Solvent & $\mathrm{kg} / \mathrm{h}$ & & & & & & & 118 & & & & & & & & \\
\hline Other organics & $\mathrm{kg} / \mathrm{h}$ & & & & 3 & & 310 & 4 & 1,405 & & & & & & 324 & \\
\hline Carbon dioxide & $\mathrm{kg} / \mathrm{h}$ & & & & & & 35 & & 68 & & & & & & & \\
\hline Methane & $\mathrm{kg} / \mathrm{h}$ & & & & & & & & & & & & & & & \\
\hline $\mathrm{H}_{2}$ & $\mathrm{~kg} / \mathrm{h}$ & 1,798 & 188 & & & & 5 & & & & & & & & & 417 \\
\hline $\mathrm{O}_{2}$ & $\mathrm{~kg} / \mathrm{h}$ & & & & & & & & 63 & & & & & & & \\
\hline $\mathrm{N}_{2}$ & $\mathrm{~kg} / \mathrm{h}$ & & & & & & 2 & & & & & & & & & \\
\hline $\mathrm{CO} / \mathrm{SO}_{x} / \mathrm{NO}_{x} / \mathrm{H}_{2} \mathrm{~S}$ & $\mathrm{~kg} / \mathrm{h}$ & & & & & & & & & & & & & & & \\
\hline Cellulose (IS) & $\mathrm{kg} / \mathrm{h}$ & & & & 1,098 & & & 7 & 22 & & & & 584 & 1,414 & 1,076 & \\
\hline Other struct. carbohydr. (IS) & $\mathrm{kg} / \mathrm{h}$ & & & & 1,466 & & & 9 & 29 & & & & 2,222 & 1,888 & 1,437 & \\
\hline Acetate (IS) & $\mathrm{kg} / \mathrm{h}$ & & & & & & & & & & & & & & & \\
\hline Lignin (IS) & $\mathrm{kg} / \mathrm{h}$ & & & & 3,034 & & & 20 & 61 & & & & 6,172 & 3,907 & 2,973 & \\
\hline Protein (IS) & $\mathrm{kg} / \mathrm{h}$ & & & & 1,136 & & & 7 & 24 & & & & & 1,462 & 1,157 & \\
\hline Cell mass (IS) & $\mathrm{kg} / \mathrm{h}$ & & & & 26 & & & & 8 & & & & & 33 & 384 & \\
\hline Other insoluble solids (IS) & $\mathrm{kg} / \mathrm{h}$ & & & & 756 & & & 5 & 15 & & & & 2,691 & 973 & 741 & \\
\hline
\end{tabular}




\begin{tabular}{|c|c|c|c|c|c|c|c|c|c|c|c|c|c|c|c|c|}
\hline \multicolumn{2}{|c|}{ INTEGRATED BIOREFINERY } & 705 & 706 & 707 & 708 & 709 & 801 & 802 & 803 & 804 & 805 & 806 & 901 & 902 & 903 & 904 \\
\hline Total flow & $\mathrm{kg} / \mathrm{h}$ & 2,791 & 11,241 & 2,972 & 806 & 38 & 14,230 & 5,389 & 9,700 & 49,543 & 11,994 & 288,713 & 282,439 & 15,873 & 11,525 & 437,448 \\
\hline Insoluble solids (IS) & $\mathrm{kg} / \mathrm{h}$ & & & & 31 & & 7,115 & 1,078 & & & & & & & & \\
\hline Soluble solids (SS) & $\mathrm{kg} / \mathrm{h}$ & & 10,454 & 2,972 & 712 & & 833 & 251 & & 12 & & & & & & \\
\hline MEK & $\mathrm{kg} / \mathrm{h}$ & & & & & & & & & & 16 & & & & & \\
\hline Renewable hydrocarbon & $\mathrm{kg} / \mathrm{h}$ & & & & & & & & & & & & & 15,652 & & \\
\hline Adipic acid & $\mathrm{kg} / \mathrm{h}$ & & & & & & & & & & & & & & 11,494 & \\
\hline Water & $\mathrm{kg} / \mathrm{h}$ & 2,791 & 787 & & 63 & & 6,261 & 4,047 & & 1,177 & 277 & 288,713 & 282,439 & 222 & & 437,448 \\
\hline Glucose (SS) & $\mathrm{kg} / \mathrm{h}$ & & & & & & 2 & & & & & & & & & \\
\hline Xylose (SS) & $\mathrm{kg} / \mathrm{h}$ & & & & & & 2 & & & & & & & & & \\
\hline Other sugars (SS) & $\mathrm{kg} / \mathrm{h}$ & & & & & & 39 & & & & & & & & & \\
\hline Other organic acids (SS) & $\mathrm{kg} / \mathrm{h}$ & & & & 31 & & 510 & & & 12 & & & & & & \\
\hline Fermentation nutrients (SS) & $\mathrm{kg} / \mathrm{h}$ & & & & 680 & & & & & & & & & & & \\
\hline Sulfuric acid (SS) & $\mathrm{kg} / \mathrm{h}$ & & 10,454 & & & & & & & & & & & & & \\
\hline Sodium hydroxide (SS) & $\mathrm{kg} / \mathrm{h}$ & & & 2,972 & & & 279 & 11 & & & & & & & & \\
\hline Sodium sulfate (SS) & $\mathrm{kg} / \mathrm{h}$ & & & & & & & 232 & & & & & & & & \\
\hline Other chemicals (SS) & $\mathrm{kg} / \mathrm{h}$ & & & & & & & 8 & & & & & & & & \\
\hline Soluble lignin & $\mathrm{kg} / \mathrm{h}$ & & & & & & 6 & & & & & & & & & \\
\hline Solvent & $\mathrm{kg} / \mathrm{h}$ & & & & & 38 & & 2 & & 8 & & & & & 30 & \\
\hline Other organics & $\mathrm{kg} / \mathrm{h}$ & & & & & & 14 & 11 & & & 54 & & & & & \\
\hline Carbon dioxide & $\mathrm{kg} / \mathrm{h}$ & & & & & & 2 & & & 11,023 & 8,666 & & & & & \\
\hline Methane & $\mathrm{kg} / \mathrm{h}$ & & & & & & & & 9,700 & & & & & & & \\
\hline $\mathrm{H}_{2}$ & $\mathrm{~kg} / \mathrm{h}$ & & & & & & & & & 95 & 10 & & & & & \\
\hline $\mathrm{O}_{2}$ & $\mathrm{~kg} / \mathrm{h}$ & & & & & & & & & 1,708 & 716 & & & & & \\
\hline $\mathrm{N}_{2}$ & $\mathrm{~kg} / \mathrm{h}$ & & & & & & & & & 35,520 & 2,254 & & & & & \\
\hline $\mathrm{CO} / \mathrm{SO}_{x} / \mathrm{NO}_{x} / \mathrm{H}_{2} \mathrm{~S}$ & $\mathrm{~kg} / \mathrm{h}$ & & & & & & & & & & & & & & & \\
\hline Cellulose (IS) & $\mathrm{kg} / \mathrm{h}$ & & & & & & & 29 & & & & & & & & \\
\hline Other struct. carbohydr. (IS) & $\mathrm{kg} / \mathrm{h}$ & & & & & & & 39 & & & & & & & & \\
\hline Acetate (IS) & $\mathrm{kg} / \mathrm{h}$ & & & & & & & & & & & & & & & \\
\hline Lignin (IS) & $\mathrm{kg} / \mathrm{h}$ & & & & & & & 80 & & & & & & & & \\
\hline Protein (IS) & $\mathrm{kg} / \mathrm{h}$ & & & & 31 & & 67 & & & & & & & & & \\
\hline Cell mass (IS) & $\mathrm{kg} / \mathrm{h}$ & & & & & & 7,048 & 910 & & & & & & & & \\
\hline Other insoluble solids (IS) & $\mathrm{kg} / \mathrm{h}$ & & & & & & & 20 & & & & & & & & \\
\hline
\end{tabular}

